\title{
Az alkotmányos identitás funkciója és alkalmazhatósága a szupranacionális térben
}

\author{
Doktori (Ph.D.) értekezés
}

Készítette: Dr. Tribl Norbert

(Kézirat lezárva: 2020. szeptember 1.)

Témavezetők:

Prof. Dr. Trócsányi László, Ph.D.

Dr. Sulyok Márton, Ph.D.

Szegedi Tudományegyetem

Állam- és Jogtudományi Doktori Iskola

Szeged, 2020 


\section{Köszönetnyilvánítás}

Ha van egy barátod, ajándékozz neki halat, de ha igazán szereted, tanitsd meg horgászni! - tartja a közmondás. Mikor látunk egy megoldatlan problémát és eldöntjük, hogy választ keresünk rá, nem feltétlenül vagyunk tisztában vele, hogy a válasz megtalálása egész lényünket kívánhatja majd, így mire sikerül megtalálni, mi magunk is más emberré válhatunk.

Ez úton köszönöm barátaimnak az Alkotmányjogi Tanszéken, hogy mellettük kereshettem válaszokat a kérdéseimre. Köszönöm családomnak, hogy elfogadták: válaszokat keresek. Végül ez úton köszönöm meg Sulyok Mártonnak és Trócsányi Lászlónak, hogy megtanítottak horgászni. 


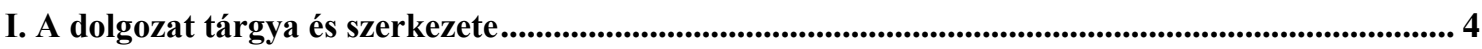

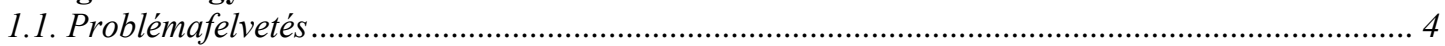

1.2. A kutatás módszertana és az értekezés struktúrája ............................................................. 14

1.3. Az alkotmányos identitás fogalmának eredete ................................................................. 23

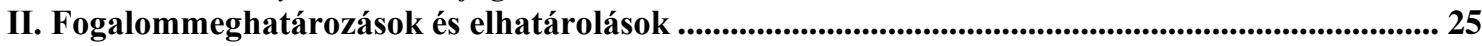

2.1. Jogelméleti alapok és az identitásképzés modellje ............................................................. 25

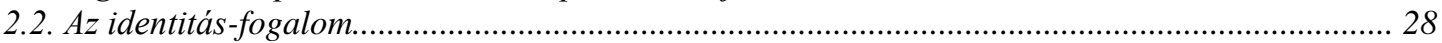

2.3. Az alkotmányos alany: közösség - alkotmány - struktúra .................................................. 31

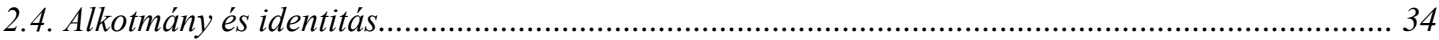

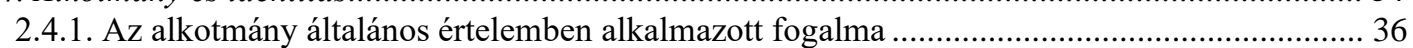

2.4.2. Az alkotmány jogi értelemben alkalmazott fogalma és az alkotmányos értékek .................. 40

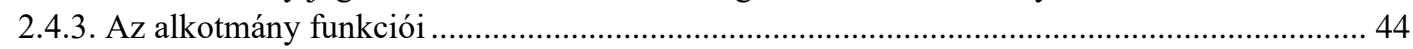

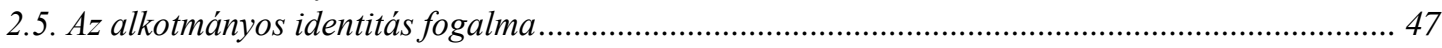

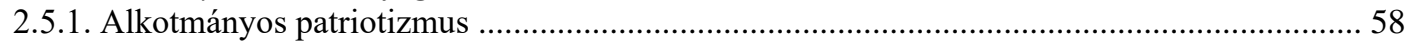

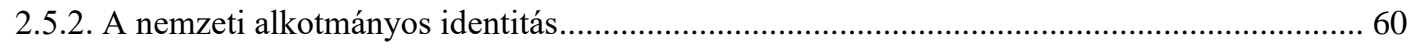

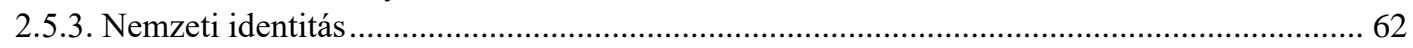

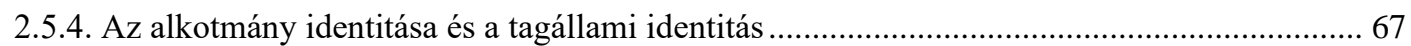

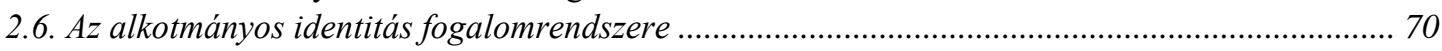

III. Szupranacionalitás, szuverenitás és az alkotmányos paradoxon .............................................. 74

3.1. A többszintü alkotmányosság rendszere és az alkotmányos paradoxon ..................................... 74

3.2. Szuverenitás a többszintü alkotmányosság rendszerében ......................................................... 84

3.3. Ép testben ép lélek: Alkotmány - szuverenitás - identitás ...................................................... 88

3.4. Az alkotmányos identitás belső oldala, mint örökkévalósági klauzulák? ................................... 90

3.4.1. Egy kérdőíves vizsgálat eredményei ......................................................................... 91

3.4.2. Az örökkévalósági klauzulák és az alkotmányos identitás közötti kapcsolat ....................... 96

IV. Egység a sokféleségben, vagy sokféleség az egységben? Alkotmányos identitás az európai

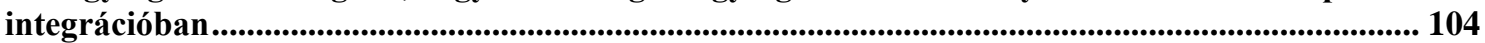

4.1. Az alkotmányos identitás külső oldala? Az EUSZ 4. cikk (2) bekezdése ..................................... 104

4.1.1. Az identitás klauzula: az EUSZ 4. cikk (2) bekezdés első fordulata .................................. 107

4.1.2. Alapvető állami funkciók: az EUSZ 4. cikk (2) bekezdés második fordulata ..................... 110

4.1.3. Következtetések az EUSZ 4. cikk (2) bekezdéséröl ........................................................... 114

4.1.4. A tagállamok és az integráció viszonya az EUSZ 4. cikk (2) tükrében............................... 117

4.2. Egy új korszak hajnalán? Alkotmányos identitás és az ultra vires aktusok a Német Szövetségi

Alkotmánybiróság PSPP döntésének tükrében..................................................................... 123

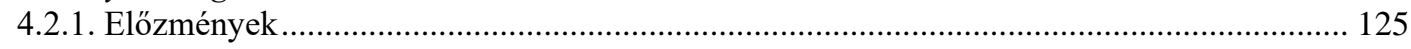

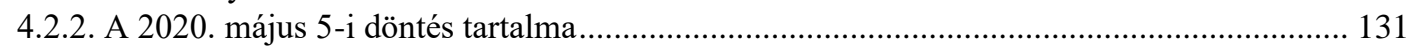

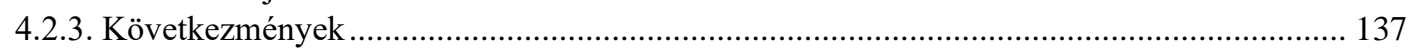

4.3. Identitásképzés szupranacionális szinten: európai (alkotmányos) identitás? ........................... 140

4.3.1. Alkotmányos közösség az Európai Unióban ............................................................... 143

4.3.2. Lehet Európának alkotmánya? .................................................................................. 145

4.4. A közös metszet? Alapvetö jogok és alkotmányos identitás.................................................. 153

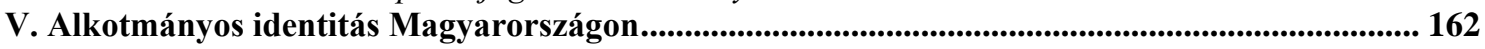

5.1. A 22/2016. (XII. 5.) AB határozat ....................................................................................... 164

5.2. Az Alaptörvény hetedik módositása .................................................................................... 175

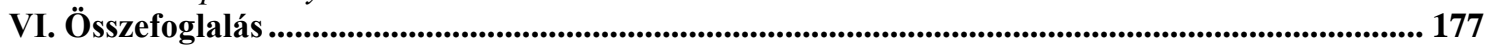

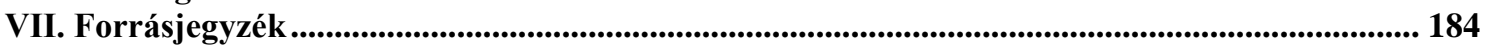

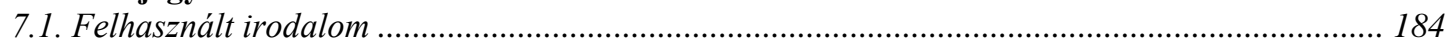

7.2. Az EUB és a tagállami alkotmánybíróságok hivatkozott határozatai ...................................... 203

7.3. Hivatkozott tagállami alkotmányok és nemzetközi szerzödések ........................................... 204

VIII. Mellékletek............................................................................................................................................... 207

1. sz. melléklet - Kérdölv az alkotmányos identitásról, az örökkévalósági klauzulákról és kapcsolatáról

az EU tagállamok AB-gyakorlataiban (2018)......................................................................... 207

2. sz. melléklet - A tagállami alkotmánybiróságok által a kérdöivre megküldött válaszok összesitése

3. sz. melléklet - A Lett Alkotmányügyi Bizottság alkotmányos identitásra vonatkozó jelentésének

kivonata angol nyelven. 


\section{A dolgozat tárgya és szerkezete}

\subsection{Problémafelvetés}

Michel Rosenfeld az alkotmányos identitás fogalmáról 1995-ben a következőket fogalmazza meg: „Hogy létrehozzunk egy, az időkön átívelö alkotmányos identitást, elengedhetetlen, hogy egybe szöjük az alkotók múltját, a saját jelenünket és a meg nem született generációk jövőjét."1 Trócsányi László 2014-ben a szuverenitás fogalmának gyengüléséről, egyúttal az alkotmányos identitás felértékelődéséről ír: „Ma, amikor a nemzeti szuverenitás a jogrendek multiplikációja és a nemzetközi kötelezettségvállalások folytán gyengülőben van, helyette felértékelödik az alkotmányos identitás fogalma."

„Amennyiben az alkotmányos identitás fogalmával való bánásmód állandósul, úgy mindkét félnek - nemzetinek és európainak is - megfelelö megfontolást és kölcsönös tiszteletet kellene mutatnia. Az Alkotmánybíróság tartsa magát az Európai Unió Bírósága által meghirdetett iránymutatásokhoz, az Európai Unió Bírósága pedig nyújtson ugyan iránymutatásokat, de ne tegyen fel kötöféket a nemzeti bíróságoknak.” - E gondolatok már a Cseh Alkotmánybíróság elnökétől, Pavel Rychetskytől hangzanak el 2017-ben, ${ }^{3}$ három évvel a Német Szövetségi Alkotmánybíróság PSPP döntése elött, amelyben a testület a német alkotmányos identitás sérelmére és az EUB döntésének ultra vires jellegére tekintettel magára nézve alkalmazhatatlannak nyilvánította a döntést. ${ }^{4}$

Az alkotmányos identitás természetéről és jelentőségéről megfogalmazott jogtudományi gondolatok sora még hosszasan folytatható lenne, amely felsorolást azonban a tematikus és tételes idézés helyett jelen értekezés hivatkozási rendszerének egészével valósítja meg a szerző. Elöljáróban azonban annyi kijelenthető, hogy a számos eltérő vélemény ellenére az elmúlt évek - évtizedek - tudományos álláspontjai alapján egy fejlődési ív rajzolódik elénk: az alkotmányos identitásról alkotott jogtudományi és jogalkalmazói álláspont folyamatosan változik, azonban az állandó változás egy fejlődési pályát jelöl ki és arról

\footnotetext{
${ }^{1}$ Rosenfeld 1995, p. 1049.

2 Trócsányi 2014a, p. 19.

${ }^{3}$ Rychetsky 2017, p. 98.

${ }^{4}$ A döntés genezisét sokkal inkább az ultra vires, mint az alkotmányos identitás képezte, az indokolásban a két fogalmi megközelítés azonban kiegészítette egymást. A határozat részletes elemzését lásd jelen értekezés 4.2. fejezetében.
} 
árulkodik, hogy a jogtudomány és a jogalkalmazás mind jobban megérti a fogalom mögött húzódó törvényszerüségeket, egyszersmind a fogalom természetét.

Néhány évtizeddel, de akár csak tíz évvel ezelőtt az alkotmányos identitás egy olyan homályba burkolódzó fogalom volt, amely iránt az európai alkotmányjog tudományában csak kevesen érdeklődtek. Az európai integráció alkotmánybírósági gyakorlatában pedig szinte nem is létezett, noha a jelentőségét megalapozó jogi keret - és probléma! - ezekben az évtizedekben már formálódóban volt. Mostanra azonban a fogalom az európai alkotmányjog egy sokat kutatott - és vitatott - alkotmányjogi területévé, vetületévé vált, amely azonban nem egyfajta ,,tudományos divat”, sokkal inkább az európai integráció történelmi léptékkel mért fiatal, ugyanakkor egyedülálló mivoltának, egyszersmind identitásválságának ${ }^{5}$ is következménye. Az alkotmányos identitás tartalma és alkalmazhatósága az európai integrációban az integráció fejlődési irányához, egyszersmind jövőjéhez kötött.

A fogalom a maitól jelentősen eltérő környezetben fogant megközelítőleg a XX. század második felében ${ }^{6}$, európai szemszögből kvázi a napjainkban kibontakozó integrációs identitásviták előfutáraként. Meghatározását árnyalja, hogy az angolszász - különösen is az amerikai - értelmezés az európaitól is jelentősen eltérő kontextusban alkalmazza azt, amely megközelítésből érintőlegesen jelen értekezés is táplálkozik. Az európai értelmezést illetően elmondható, hogy az alkotmányos identitás fogalma az elmúlt években összeforrott az Európai Unió és tagállamai közötti alkotmányos viszony meghatározásával, amelynek következtében maga a fogalom is éppoly ellentmondásossá vált, mint a viszonyrendszer, amelyre alkalmazni próbáljuk. ${ }^{7}$

Az alkotmányos identitás fogalomköre ennek eredményeként olyan megosztó jelenség, amelyben a koncepció mellett érvelők lehetőséget, egyúttal eszközt látnak a tagállamok és az európai integráció között húzódó (alkotmányos és politikai) feszültség enyhítésére. ${ }^{8}$ A szkeptikusok pedig egy újabb erőtlen kísérletként tekintenek a fogalomra, amely a tagállamok alkotmányainak (elvi, ám a gyakorlatban nem érvényesített) integrációval

\footnotetext{
${ }^{5}$ Sigmund 2006, p. 66., Manurung 2015, p. 8.

${ }^{6} \mathrm{~A}$ fogalom eredetével részletesen jelen értekezés 1.2. fejezet foglalkozik.

${ }^{7}$ Vö.: Manurung 2015. pp. 15-16.

8 Trócsányi 2014b, pp. 71-80.
} 
szembeni dominanciáját hivatott kifejezésre juttatni. ${ }^{9} \mathrm{Az}$ európai alkotmányjogi diskurzusban egyre nehezebb elválasztani egymástól a politikai és alkotmányjogi megfontolásokat és ez az alkotmányos identitás esetén különösen is érezhető. Találkozhatunk olyan álláspontokkal, amelyek szerint az euroszkeptikus politikai tömbök az alkotmányos identitás fogalmát az integrációval szembeni eszközként kívánják alkalmazni. ${ }^{10}$

Mindennek ellenére az európai alkotmányjog-tudománynak ${ }^{11}$ tényként kell kezelnie, hogy az alkotmányos identitás az elmúlt években az európai integráción belül a tagállami alkotmánybíróságok gyakorlatában olyan gyakorlati jelentőséggel rendelkező fogalommá vált, amelynek jelentősége folyamatosan növekszik ${ }^{12}$ és kerül így az alkotmányjogi és európai jogi tudományos diskurzus egyik központi áramlatába. ${ }^{13}$ Ennek oka, hogy az európai kétszintű alkotmányosság rendszerében az integráció egy régóta húzódó központi vitáját jelenti az uniós jogrend és a tagállamok alkotmányos szabályainak ${ }^{14}$ összeütközése. ${ }^{15}$ Ugyan az Európai Unió Bírósága (a továbbiakban EUB) a Costa vs. E.N.E.L. ügyben ${ }^{16}$ elvi éllel mondta ki, hogy a tagállamok nem hivatkozhatnak a nemzeti alkotmányok szabályaira az integrációval szemben, mégis az EUB elvi jelentőségű döntése óta azt látjuk, hogy az EUB határozatában lefektetett szabályok nem állhatnak meg korlátok nélkül: a tagállamok nem fogadják el az uniós jog nemzeti alkotmányok feletti feltétlen dominanciáját. Annál is inkább, mivel azóta maga a Lisszaboni Szerződés nevesíti a tagállamok alapvető alkotmányos sajátosságainak védelmét az EUSZ 4. cikk (2) bekezdése által, amely kimondja, hogy az Európai Unió tiszteletben tartja a tagállamok nemzeti identitását. Különösen is jelentős gyakorlattal rendelkezik e téren a Német Szövetségi Alkotmánybíróság, amelynek identitásra vonatkozó gyakorlata a közismert Solange döntésekkel kezdett kialakulni és amelynek egy meghatározó állomása a 2020. május 5-i PSPP döntés. A későbbiek során részletesen vizsgált határozat esetén valamelyest árnyalja a képet, hogy a német testület az alkotmányos identitást egy olyan uniós döntéssel szemben hívta fel, amely álláspontja

\footnotetext{
${ }^{9}$ Vö.: Chronowski-Vincze 2017, pp. 96-100.

${ }^{10}$ Vö.: Goldmann 2020, p. 46.

${ }^{11}$ Vö.: Chronowski 2015, pp. 20-27.

12 Magyarországon az alkotmányos identitás doktrínája különösen az Alkotmánybíróság sokat támadott 22/2016. (XII. 5.) AB határozatával került a figyelem középpontjába.

${ }^{13}$ Belov 2017, p. 74.

${ }^{14}$ Belov 2017, p. 76.

15 Trócsányi 2014 b, p. 474.

${ }^{16}$ C-6/64 - Flaminio Costa kontra E.N.E.L.
} 
szerint az Alapító Szerződésekből nem következik, ezért ultra vires. Vagyis első olvasatra a döntés az uniós jog és nemzeti alkotmányok összeütközéséről szól, ez azonban csak részben van így. A PSPP döntés esetén a problémát egy olyan, a nemzeti joggal (és alkotmánnyal, illetve az alkotmányos identitással) összeegyeztethetetlen döntés jelentette, amely az alkotmánybíróság szerint ellentétes az Alapító Szerződésekkel, vagyis egy szerződés-ellenes uniós döntés sértette az alkotmányos identitást. Ahogyan az a későbbiek során látható lesz, a PSPP esetén a probléma fundamentuma tehát nem is igazán a jogösszeütközés, sokkal inkább az EUB és a nemzeti alkotmánybíróságok egymáshoz füződő, ugyanakkor meghatározatlan viszonya.

A többszintű alkotmányosság rendszerét tekintve, ${ }^{17}$ azt a végletekig leegyszerüsítve egy kettős, egymással szemben ható erőhatással találkozunk: az európai egység megteremtésének jegyében munkálkodó tagállamok - alkotmányos berendezkedésük védelme mellett - a hatáskör és szuverenitástranszfer (transfer of competences) folytán a nemzeti szuverenitásból fakadó jogosultságaik gyakorlását az Európai Unió alapító szerződéseiben meghatározott keretek között az integráció útján gyakorolják. ${ }^{18}$ Ebben a viszonyrendszerben az egységes fellépés iránti szükséglet, illetve igény jelenti azt az erőt, amely a tagállamokat alkotmányos rendszereik összehangolására és az együttmüködésre készteti. Ezzel szemben az integrációban résztvevő tagállami alkotmányos rendszerek összehangolásához szükségszerü kompromisszumok meghozatala során megjelenő korlátok (a „szuverenitásféltés”) testesítik meg azt az ellenerőt, amely az integrációt jellemző alkotmányos feszültséghez vezet, hiszen a tagállamok féltékenyen örzik tagállami integritásukat, alkotmányos sajátosságaikat. A jelenséget és az európai környezetet Sulyok 2016-ban az „európai alkotmányos átmenet” időszakaként aposztrofálta, amely során - álláspontja szerint - Európa vívódásban él önmagával és tagállamaival. ${ }^{19} \mathrm{Az}$ általa tett kijelentés óta eltelt három évben azonban az európai integráció egy, az alkotmányos átmenetnél alapvetőbb problémával került szembe: az önazonosság hiányával. Többek között az Egyesült Királyság kilépési procedúrája ${ }^{20}$, illetve az európai integrációt próbára tevő migrációs válság ${ }^{21}$ felerősítették az Európai

\footnotetext{
${ }^{17}$ Vö.: Besselink 2007

${ }^{18}$ Vö.: Magyarország Alaptörvénye, E) cikk (2) bek.

${ }^{19}$ Sulyok 2016 a, p. 9.

${ }^{20}$ Az Egyesült Királyságban a kilépésről tartott 2016-os népszavazást követő folyamatokról bővebben lásd: Prieger - Klemm 2019

21 A menekültválságról bővebben lásd: Ádány 2016, illetve az Európai Parlament összefoglalóját: $\operatorname{COM}(2018) 798$ („Managing Migration in all its Aspect: Progress under the European Agenda on
} 
Unió integritásának hiányosságait: elsőként pedig egy kiforrott önazonosság hiányát. Mindezek a folyamatok a Lisszaboni Szerződés hatályba lépését követő stabilizációs ciklust követően egy kvázi destabilizációs időszakot indítottak el, amelyben számos esetben nem a résztvevő tagállamok és az integráció közötti viszony, hanem a tagállamok összetartozása, az Európai Unió önazonossága kérdőjeleződik meg, és kerül előtérbe a résztvevő tagállamok szuverenitásának védelme (ld. szuverenitásféltés). ${ }^{22}$

Erre vezethető vissza, hogy az elmúlt években kiéleződött az integrációt a kezdetektől meghatározó „egyesítő - széthúzó” jelleg ${ }^{23}$ közötti ellentét, amely számos egyéb tényező mellett a tagállami alkotmánybíróságok alkotmányos identitásról szóló döntéseinek elterjedését idézte elő. Minél meghatározatlanabb az európai integrációt összetartó kohéziós erőtér, a tagállamok annál nagyobb hangsúlyt fektetnek a lehető kevesebb bizonytalanságot támasztó viszonyrendszer kialakítására az európai jogrend és a tagállami alkotmányok között. Mostanra az is kijelenthetö, hogy a következő válság, amellyel az Európai Uniónak szembe kell néznie, az a COVID-19 járvány következtében kialakulóban lévő gazdasági recesszió, amelynek kétségtelenül meghatározó szerepe lesz az integrációs folyamatra nézve ${ }^{24}$, azt azonban jelen pillanatban még megalapozatlan lenne megjósolni, hogy ez az újabb válság az integrációs folyamatot erősítő, vagy gyengítő pályára fogja terelni.

$\mathrm{Az}$ alkotmányos átmenet, illetve az európai identitás és értékkrízis időszakában az integráció oldaláról meghatározó jelentőségü az EUSZ 4. cikk (2) bekezdése, amely kimondja, hogy az Unió tiszteletben tartja a tagállamok nemzeti identitását, amely elválaszthatatlan része azok alkotmányos berendezkedésének (elsö fordulat), illetve az Unió tiszteletben tartja a tagállamok alapvető állami funkcióit (második fordulat).

Külön is szükséges kiemelni az Európai Unió Bíróságának e cikkel összefüggő kényszerüen szükszavú gyakorlatát, ${ }^{25}$ amely a hallgatásban és fontolva haladásban találta

Migration” - https://ec.europa.eu/home-affairs/sites/homeaffairs/files/what-we-do/policies/europeanagenda-migration/20181204_com-2018-798-communication_en.pdf

${ }^{22}$ Vö.: Balogh-Békési 2014, p. 1.

${ }^{23}$ Vö.: Orbán 2020, pp. 7-13.

${ }^{24}$ A Next Generation EU, mint a válság gazdasági hatásaira adott uniós válasz már közzétételét követően is a szuverenitást érintő alkotmányos konfliktust idézett elő pl. Finnországban. Bővebben lásd: LeinoSandberg 2020.

${ }^{25}$ Különösen: Costa vs. E.N.E.L. ügy, Simmenthal (I) ügy (35/76 Simmenthal SpA v Ministere des finances italien,1976), de akár a 26/62. sz. Van Gend en Loos, vagy a Taricco és társai (C-105/14. sz.) ügyek. 
meg a tagállamok és az integráció közötti fenntartható alkotmányos viszony óvatos formálásának útját és amely feltehetően a német PSPP döntésre tekintettel a jövőben ki kell hogy mozduljon a hallgatás medréből.

Az alkotmányos átmenetből, illetve a fenti értékkrízisből eredő feszültségre, a felmerülő kérdésekre és problémákra azonban a válaszokat - egyelőre - nem kifejezetten az integráció, mint inkább a tagállamok szintjén kell keresnünk. Ezen a ponton válnak aktuálissá Trócsányi - bevezetőben idézett - gondolatai, amely szerint a jogrendek multiplikációja során felértékelődik az alkotmányos identitás fogalma, hiszen az alkotmányos identitás elmélete alkalmas lehet a tagállami alkotmányok és az integráció viszonyának rendezésére.

Jelenleg a jogtudományi álláspontokból, illetve a nemzeti alkotmánybíróságok gyakorlatából kiolvasható uralkodó álláspont szerint az alkotmányos identitás európai fogalmát a tagállamok autentikus - erga omnes hatályú - alkotmányértelmezőiként a tagállami alkotmánybíróságoknak (alkotmányértelmezésre jogosult legfelsőbb bírói testületeknek) kell értelmezni, tartalommal feltölteni ${ }^{26}$ és ezáltal meghatározni az európai jogrend és a tagállami alkotmányok közötti kapcsolatot. A kirajzolódóban lévő gyakorlat azonban nem korlátlan: a tagállami alkotmánybíróságok mozgástere erősen korlátozott az uniós jog - és így az EUSZ 4.) cikk (2) bekezdésének - eredeti értelmezőjeként az Európai Unió Bíróságának joggyakorlata által. Ugyanakkor a PSPP döntés rávilágított arra a heves indulatokat ${ }^{27}$ kiváltó tényre, hogy az EUB döntéshozatali lehetőségei sem korlátlanok: az EUB döntéshozatala az Alapító Szerződések által meghatározott és mint ilyen, a testület alázattal tartozik a tagállamok - mint a Szerződések urai - által kialakított tartalom érvényre juttatása iránt.

Már önmagában a nemzeti alkotmánybíróságok, illetve az EUB közötti kapcsolat is problémás kérdéseket szül, hiszen a nemzeti alkotmányok autentikus értelmezői az alkotmánybíróságok, míg az uniós jog autentikus értelmezője kizárólag az EUB, vagyis amíg vagy az Alapító Szerződések, vagy a nemzeti alkotmányok nem rögzítik minden

\footnotetext{
${ }^{26}$ Vö.: Sulyok 2014, p. 51.

27 Lásd pl. Kelemen R. Daniel, Piet Eeckhout, Federico Fabbrini, Laurent Pech és Uitz Renáta közös nyilatkozatát a Verfassungsblogon 2020. május 26-án: https://verfassungsblog.de/national-courts-cannotoverride-cjeu-judgments/
} 
kétséget kizáróan a közöttük fennálló viszonyrendszert, addig az EUB és a tagállami alkotmánybíróságok között is fennáll egy érzékeny, ám annál jelentősebb feszültség, amelyet jelenleg a testületek a jogi kötőerővel ugyan nem rendelkező, a gyakorlatban azonban annál fontosabb európai alkotmányos párbeszéd ${ }^{28}$ intézményével próbálnak feloldani és amely megmutatkozott a PSPP döntés során.

Az alkotmányos identitásról kialakult viták egyes frontvonalainak, a vitás kérdéseknek az összegyüjtése is jelentős vállalkozást jelent, a kép azonban lassan kirajzolódni látszik a szakirodalmi feldolgozottság és a joggyakorlat bővülésével. Ha kategorizálni kívánjuk az egyes problémás területeket, akkor mindenekelőtt nevesíthetjük a fogalomelhatárolások problémakörét ${ }^{29}$, a szuverenitás és az alkotmányos identitás kapcsolatának meghatározását, ${ }^{30}$ illetve az alkotmányos identitás európai jogrendben betöltött szerepének kijelölését ${ }^{31}$ annak figyelembevételével, hogy a vita során egymás mellett léteznek a jogtudományi és a folyamatosan bővülő alkotmánybírósági gyakorlatban testet öltő megfontolások, amelyek mintegy szimbiózis-szerüen forrnak össze.

Megjegyzést érdemel, hogy Magyarország Alaptörvényének hetedik módosításával az Európai Unió tagállamai közül elsőként - sokak által, többek között jelen értekezés szerzője által is vitatott formában - Magyarország alkotmányi szinten is rögzítette az alkotmányos önazonosság védelmét, így az a jogtudományi és az alkotmánybírósági gyakorlatban történő alkalmazás után megjelent a tételes jog rendelkezései között is. ${ }^{32}$

Az alkotmányos identitás fogalmának legnagyobb problémája tehát jelenleg annak nehezen körülhatárolható jellege, illetve az ebből fakadó fogalmi meghatározatlanság, amely olykor problémássá teszi az alkalmazhatóságot is. Az alkotmányos identitás nem olyasvalami, amelyre - egyelőre - valamely alkotmányjogi teszt, vagy szürő mechanizmus alkalmazásával rá tudnánk mutatni ${ }^{33}$, majd ezt követően érvényesülne egy

\footnotetext{
${ }^{28}$ Vö.: Drinóczi 2016a, pp. 213-233.

${ }^{29}$ Vita folyik többek között arról, hogy mi a kapcsolat a szuverenitás és az alkotmányos identitás között. Vö.: Orbán 2018, pp. 3-5. Vita folyik arról, hogy mi a kapcsolat a nemzeti identitás és az alkotmányos identitás között, vagy arról, hogy az alkotmány identitása és az alkotmányos identitás vajon egy és ugyanaz a kör-e. Vö.: Drinóczi 2016b.

${ }^{30}$ Vö.: Kruzslicz 2019, pp. 43-148.

${ }^{31}$ Vö.: Kruzslicz 2019, pp. 148-162., Orbán 2020, pp. 37-104.

${ }^{32}$ A hetedik módosításról bővebben lásd: Grósz 2019, illetve Orbán 2020, pp. 80-81.

${ }^{33}$ Ugyan erre irányuló kísérletek felfedezhetők a tagállami alkotmánybíróságok joggyakorlatában. Vö: az identitás tesztje a magyar Alkotmánybíróság 22/2016 (XII. 5.) AB határozatában.
} 
magától értetődő védelmi mechanizmus az Európai Unió jogrendjén belül, amely - ilyen igényre tekintettel - védelemben részesítené a megnevezett identitáselemet. Jelenleg eltérően értelmezzük a fogalmat tagállamonként, illetve a tagállamoktól is eltérően értelmezi maga az EUB is. Ha mindez nem eredményezne elegendő instabilitást, részben mást gondol a fogalomról a jogtudomány és a joggyakorlat is.

A fogalmi bizonytalanság számos tényezőre vezethető vissza, amelyek közül az első és legfontosabb az alkotmányos paradoxon: egy olyan jelenséget igyekszünk meghatározni

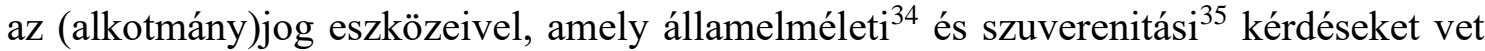
fel, egy olyan (szupranacionális) környezetben, amely mind alkotmányjogi, mind államelméleti szempontból fiatalnak, szinte születőben lévőnek tekinthető és amelyet számos tudományos forrás sem államként, hanem a kortárs nemzetközi kapcsolatok legfontosabb nem állami szereplőjeként nevesíti. ${ }^{36}$ Jelen értekezésben a szerző ebben a koordináta rendszerben kíván hozzájárulni az alkotmányos identitás fogalmi kereteinek meghatározásához.

Az alkotmányos identitás európai fogalma egy olyan rendező elvet testesít meg, amellyel az európai nemzetek ki akarják békíteni a kibékíthetetlent: meghatározni a nemzeti alkotmányok és az integrációs jogrend viszonyát. Előre vetítve jelen értekezés következtetéseit, az Európai Unió tagállamai a nemzeti alkotmányokban megjelenő olyan alkotmányi értékeket, illetve a tagállami politikai és alkotmányos berendezkedés olyan egyedülálló intézményeit azonosítják az alkotmányos identitás fogalmával, amelyek az adott tagállam történelmi sajátosságaiból fakadóan, kizárólag az adott tagállamra jellemző értékek és intézmények, illetve a történelmi, társadalmi környezetből fakadóan más tagállamoktól eltérő tartalommal bírnak.

Az alkotmányos identitás elemeinek sajátos jellemzője, hogy azok - többek között az EUSZ 4. cikk rendelkezése folytán - önmagukban is az Alapító Szerződések által védett tagállami attribútumoknak tekintendők. Az ez iránti igény azonban csak részben jogi természetü, illetve olyan területen jelenik meg, ahol dogmatikailag ugyan kialakítható

\footnotetext{
${ }^{34}$ Vincze-Chronowski 2018, pp. 20-28.

35 A kialakult és kialakulóban lévő jogtudományi álláspontok és viták egyik meghatározó területe az alkotmányos identitás és a szuverenitás kapcsolatának meghatározása, illetve a két fogalom elhatárolása. Vö.: Blutman 2019, pp. 88-91., illetve Drinóczi 2016b.

${ }^{36}$ Vö.: Sulyok 2017b, pp. 37-53.
} 
egy olyan viszonyrendszer-elmélet, amely megfelel az európai integrációs folyamat (és így az azt alkotó nemzetek) természetének, azonban a probléma feloldására alkalmatlan: az alkotmánybíróságok és az EUB joggyakorlatában. A tagállami nemzeti alkotmányok és az uniós jogrend viszonya olyan kérdés, amelyet - ellentétben az eddig kialakult gyakorlattal - nem az EUB-nek és nem a nemzeti alkotmányértelmezőknek kellene meghatározni, hanem a tagállamok legfelsőbb döntéshozó szerveinek, és az így meghatározott viszonyrendszert az unió legmagasabb szintü jogforrásaiban, az Alapító Szerződésekben kellene rögzíteni. Ez azonban széles körü - pontosabban egyhangú politikai konszenzust feltételez és olyan döntés, amely alapvetően határozná meg az Európai Unió fejlődésének következő évtizedeit. A német PSPP döntés szintén rávilágított erre a problémára: a döntést követően megszületett egy hatásköri bíráskodást folytató testület gondolata, illetve sürgetővé vált az igény, hogy a problémát valamilyen módon megoldjuk.

Az alkotmányos identitás fogalmi rendszere alkalmas eszköz lehet a nemzeti alkotmányok és az uniós jog közötti viszony rendezésére, kvázi mint a szupranacionális alkotmányos tér rendezőelve, azonban ehhez pontosan körülhatárolt fogalmi rendszerre van szükség, amely alkalmas arra, hogy általánosan elfogadottá váljon az integrációban, majd a jogtudomány és az alkotmánybírósági gyakorlat bölcsőjéből az európai politikai döntéshozatal dimenziójáig jusson, mint az európai alkotmányos tér egyik meghatározó jogintézménye, amely részben képes megfelelő módon kialakítani az uniós jogrend és a nemzeti alkotmányok közötti viszonyrendszert. Azt azonban szükséges rögzíteni, hogy az alkotmányos identitás most sem és a jövőben sem lesz alkalmas eszköz az EUB és a nemzeti alkotmánybíróságok kapcsolatának kielégítő rendezésére és az ultra vires aktusok problémájára. Az alkotmányos identitás tartalmából fakadóan egy olyan fogalom, amelyet mindkét testületnek (testületeknek) értelmeznie kell, de nem olyan, amely meghatározza a közöttük lévő relációt.

A fentiekre tekintettel alapvető fontosságú, hogy a kérdésben folytatott tudományos vita ne váljon, ne válhasson parttalanná egy olyan fogalomról, amelynek tartalma a végletekig bővíthető és formálható. Az alkotmányos identitás organikus jellege nem jelenthet korlátok nélküli változékonyságot. ${ }^{37} \mathrm{~A}$ fogalmi meghatározatlanság, a koherens fogalmi

\footnotetext{
${ }^{37}$ Jacobsohn 2013, p. 7.
} 
rendszer hiánya, illetve az identitás pszichológiai, szociológiai fogalmának alkotmányjogi koordináta rendszerben történő értelmezése olyan széles értelmezési spektrumot teremt(ett), amelynek eredményeként az alkotmányos identitásról szerteágazó vita bontakozott ki és amely számos esetben híján van a megfelelő jogelméleti megalapozottságnak. Ettől az igénytől vezérelve úgy gondolom, hogy valamennyi, az alkotmányos identitás fogalmi körének értelmezésére irányuló kísérlet szilárd jogelméleti alapokon kell, hogy nyugodjon, illetve szükséges egy olyan fogalmi rendszer megalkotása, amely egyrészről

(i) következetesen meghatározza a nemzeti identitás, a tagállami identitás, az alkotmányos identitás, a nemzeti alkotmányos identitás, illetve az alkotmányidentitás fogalmak jelentését,

(ii) meghatározza a szuverenitás és az alkotmányos identitás közötti kapcsolatot,

(iii) tisztázza és ezáltal megteremti ez utóbbi fogalom jogelméleti alapjait,

(iv) figyelembe véve a szupranacionális tér sajátosságait.

Értekezésemben arra vállalkozom, hogy az angolszász ${ }^{38}$ és európai jogirodalom alapján a lehetőségekhez mérten koherens, jogelméleti alapokon nyugvó fogalmi rendszert alakítsak ki az alkotmányos identitás fogalmának minél pontosabb meghatározhatósága érdekében, majd az európai integrációban jelenleg rendelkezésre álló joggyakorlat segítségével meghatározzam az alkotmányos identitás jelenlegi funkcióját, illetve alkalmazási területeit az európai alkotmányos térben, hogy ezáltal a koncepció (jogintézmény?) jövőjére vonatkozó következtetések váljanak megfogalmazhatóvá.

\footnotetext{
${ }^{38}$ Különösen Gary J. Jacobsohn és Michel Rosenfeld.
} 


\subsection{A kutatás módszertana és az értekezés struktúrája}

Értekezésem célja az alkotmányos identitás jogelméleti alapokon nyugvó, koherens fogalomrendszerének meghatározása, amelyhez többek között Gary J. Jacobsohn és Michel Rosenfeld amerikai szerzők munkásságát vettem alapul. Rosenfeld és Jacobsohn az alkotmányos identitásról írt munkáikban filozófiai és jogelméleti, illetve alkotmányelméleti alapokból indulnak ki és ezekre az alapokra építve vonnak le következtetéseket, illetve építenek identitás-elméleteket. Rosenfeld többek között Hegel tételeit alkalmazza az alkotmányos identitás alapjául szolgáló mechanizmusok meghatározásakor. Álláspontom szerint ez a fajta jogelméleti megközelítés az európai fogalom-meghatározási kísérletek során sok esetben hiányzik és többek között ez vezet az alkotmányos identitás koncepciója körüli bizonytalanságokhoz. Ezért egy szilárd jogelméleti megalapozottság elengedhetetlen, hogy a fogalom európai tartalma stabilizálódhasson a jövőben.

A jogelméleti alapok áttekintése - és kiegészítése - után, illetve egy koherens fogalmi rendszer felállítását követően az értekezés során a kialakított fogalmi háló tükrében az európai integrációban vizsgálom az alkotmányos identitás gyakorlati alkalmazhatóságát. Erre tekintettel a vizsgálat és így az értekezés két fő logikai egységre osztható: az első, jogelméleti rész a jogtudomány és a joggyakorlat által kialakított fogalmak, illetve az alkotmányos identitás mögött húzódó államelméleti és alkotmányjogi folyamatok vizsgálatára, egyúttal rendszerbe foglalására irányul (II. fejezet). Az értekezés második fö részében (III., IV. és V. fejezetek) a szupranacionális berendezkedésből fakadó elveket és törvényszerüségeket vizsgálom az identitásképzés és az alkotmányos identitás, illetve a kialakított fogalmi rendszer szemüvegén keresztül, kitérve az EUB és a nemzeti alkotmánybíróságok joggyakorlatára. Az értekezésben mellőzöm ugyanakkor e gyakorlat tételes elemzését, arra csak a célkitüzésekhez szükséges mértékig térek ki, tekintettel egyrészről a vonatkozó gyakorlat jogtudományi feldolgozottságára, ${ }^{39}$ másrészről arra a megfontolásra, hogy az EUB és a nemzeti alkotmánybíróságok gyakorlata az alkotmányos identitás koncepciójának meghatározó - és azt elsődlegesen formálni képes - forrásai ugyan, azonban a jogelméleti megalapozottság, fogalmi rendszer, illetve az

\footnotetext{
${ }^{39}$ Vö.: Sulyok 2014, Drinóczi 2016b, Drinóczi 2016c, Somssich 2018, Orbán 2020, pp. 112-194.
} 
európai integráció szupranacionális jellegéböl fakadó törvényszerüségek relációjában csak egy részterületet képeznek.

$\mathrm{Az}$ értekezés első fő részében a rosenfeldi és hegeli filozófia tételeiből kiindulva az identitásképzés elsődleges forrásaként az állam kialakítására képes, nemzetet alkotó, homogén emberi csoportot - démosz -, mint önálló entitást tekintem, amely a természetes alkotmány időszakát ${ }^{40}$ követően a strukturális önszerveződés érdekében létrehozza saját alkotmányos berendezkedését. A nemzetnek - mint homogén közösségnek - ezen identitásképzés szempontjából megközelített felfogását az értekezésben alkotmányos közösségként nevesítem, mellőzve a nemzetfogalom lehetséges szociológiai és államelméleti felfogásának egyes kérdéseit. Teszem mindezt azzal a céllal, hogy a megalkotott modell a nemzetfogalomból fakadó torzító tényezők kizárásával alkalmassá váljon a homogén közösség identitásképző képességének, illetve az identitásképzés folyamatának bemutatására.

A szuverenitásra, mint az alkotmányos közösség által létrehozott entitás (az állam) egy fundamentális ismérvére tekintek, amely végső soron az alkotmányos közösséget megillető önrendelkezés, a döntés jogának leképeződése, majd összpontosulása az állam létrejövetelét követően és mint ilyen, forrása és egyben előfeltétele az állami struktúra és társadalmi berendezkedés, vagyis az alkotmányos rendszer (az EUSZ 4. cikk (2) bek. terminológiáját alkalmazva „alkotmányos berendezkedés”) létrejövetelének. Az alkotmányos berendezkedés kialakítása az alkotmányos közösség társadalomba rendeződésének szükségszerü következménye, amely azonban feltételezi a kialakított struktúra iránt támasztott azon követelményt, hogy az megfelel az életre hívó társadalom karakterének: az alkotmányos közösség - pontosabban a közösség tagjai - képesek azonosulni a létrejövő struktúrával, ezáltal képesek azt elfogadni, vagyis a közösség kollektív identitása visszatükröződik az általa megalkotott struktúrán.

Az alkotmány egyrészről forrása annak az állami és társadalmi rendnek, amelyben az alkotmányos közösség létezik, másrészről meg is testesíti azt: az alkotmányban fejeződik ki az államot létrehozó társadalmi szerződés és mint ilyen, az alkotmány -

\footnotetext{
${ }^{40}$ Vö.: Deli 2018, pp. 121-149.
} 
elválaszthatatlan egységet alkotva létének alapjával ${ }^{41}$ - szintén forrása, egyúttal megtestesítője lesz az állami szuverenitásnak is. Mindez azt is jelenti, hogyha az állami, társadalmi struktúrának meg kell felelnie az azt életre hívó közösség identitásának, akkor ennek az identitásnak tükröződnie kell az alkotmányos berendezkedést megtestesítő és konstituáló dokumentumban, az alkotmányban is. ${ }^{42}$ Amennyiben az alkotmányos értékek oldaláról közelítjük meg a kérdést, az alkotmányban rögzített értékeknek tükrözniük kell az azt létrehozó közösség értékeit. Az alkotmány és az alkotmányos közösség közötti kölcsönhatás természetét Habermas alkotmányos patriotizmus elmélete írja le. ${ }^{43}$

Az alkotmányos közösség által - a szuverenitást kifejező alkotmányon keresztül létrehozott alkotmányos rendszer (berendezkedés), a fentiekből fakadóan, szükségszerüen olyan - az adott alkotmányos közösségre és csakis arra - jellemző egyedi értékeket, intézményeket, társadalmi szervező elveket (jogelveket?) hív életre, amelyek egyediesítik, jellemzik és egyben meghatározzák nem csak az alkotmányos közösséget, de már magát az alkotmányos berendezkedést is. Ezeket a tényezőket - amelyeknek vizsgálatára jelen értekezés irányul - egyrészröl meghatározza az alkotmányos közösség identitása (nemzeti identitás), illetve az alkotmányos berendezkedést kialakító valamennyi tényező (alkotmányos közösség, alkotmányozó hatalom, alkotmány), másrészről az az időben előrehaladó fejlődési folyamat, amelyen a kialakuló alkotmányos berendezkedés keresztülmegy: az állam, illetve nemzet történelme.

Azt az entitást, amely a fenti tényezőket magában foglalja és az egyes tényezők egymásra gyakorolt kölcsönhatása - illetve ezek törvényszerüségei - által meghatározott, az értekezésben kialakított modellben - a Rosenfeld által megalkotott rendszert követve alkotmányos alanyként nevesítem. Hasonlóan az alkotmányos közösség és a nemzet elhatárolásához, az alkotmányos alany és az állam elkülönítésekor is az a megfontolás vezérelt, hogy egy olyan, az identitásképzés folyamatára koncentráló fogalmat alkalmazzak, amely nem terhelt számos, az identitásképzés kérdéskörén kívül eső torzító tényezővel.

${ }^{41}$ Vö.: Hüposztatikus egység, amelyben Jézus Krisztusban az emberi természet egyesült a Fiú isteni személyével, mint létének alapjával. Bővebben lásd: Magyar Katolikus Lexikon http://lexikon.katolikus.hu/H/hüposztatikus\%20egység.html

${ }_{42} \mathrm{Az}$ alkotmány fogalmának lehetséges értelmezési lehetőségeit bővebben lásd később a vonatkozó fejezetben.

${ }^{43}$ Erről bővebben lásd szintén az értekezés vonatkozó fejezetét. 
Az identitásképzés folyamatában tehát az állam, mint alkotmányos alany képezi azt az entitást, amely az egyes - fentebb nevesített - faktorok egymásra gyakorolt kölcsönhatásának eredményeként az alkotmányos identitás hordozójává válik. Az identitásképzés során szerepet játszó tényezők egymáshoz füződő viszonyát az 1. sz. ábra szemlélteti.

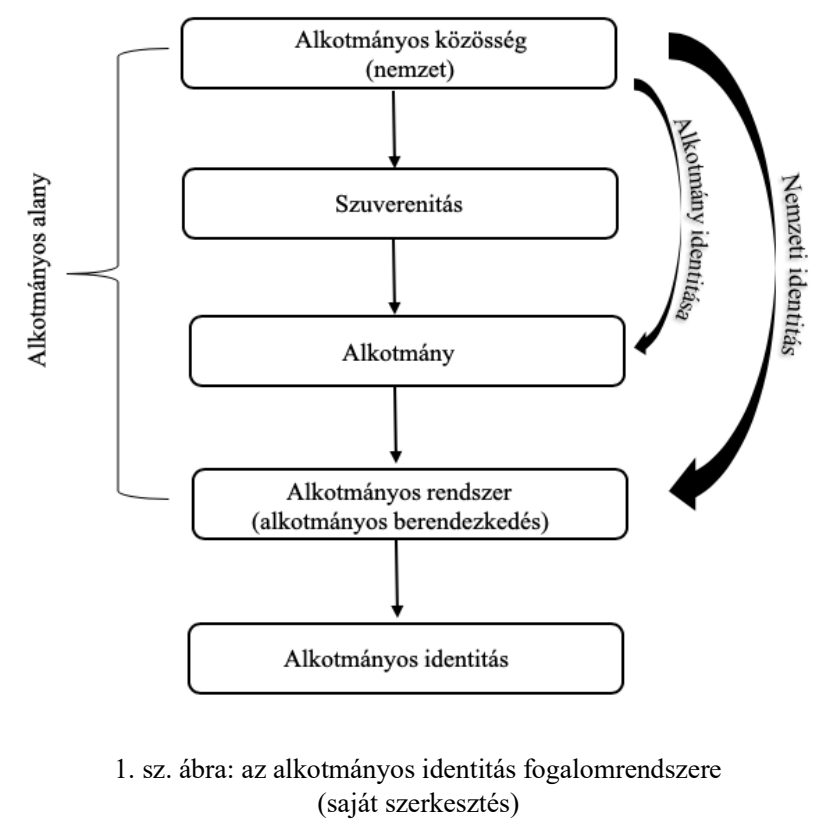

A megalkotott modellben - az 1. sz. ábrának megfelelően - az alkotmányos identitást az alkotmányos alanyon „kívül” manifesztálódó, az alkotmányos alanyon belül egymással kölcsönhatásban álló tényezők viszonyából kialakuló eredményként fogom fel, a nemzeti identitástól és az alkotmányidentitástól elkülönítve. Elöbbi alatt az alkotmányos közösség identitását értem, azonban az alkotmányos alanyon belüli egyéb tényezőkkel fennálló kölcsönhatások nélkül - vagy megközelítéstől függően, azokat megelőzően. Utóbbi alatt az alkotmány megalkotásának körülményei által meghatározott olyan identitást értek, amelynek hordozója maga a dokumentum - dokumentumok - és nem maga az alkotmányos rendszer. Teszem ezeket az elkülönítéseket azon megállapítás mellett, hogy a nemzeti identitás, az alkotmányidentitás és az alkotmányos identitás hermetikusan nem elválasztható fogalmak, bennük közös elemek azonosíthatók, azonban terjedelmükben és hordozójukban egymástól elkülönülnek. A nemzeti identitást hordozó entitás az alkotmányos közösség, az alkotmány identitását hordozó entitás maga az alkotmány, míg az alkotmányos identitást az ezek által életre hívott, alkotmányos berendezkedést kialakító alkotmányos alany hordozza. 
A fogalomrendszer és az alkotmányos identitás kialakulásakor lezajlódó identitásképzés modelljének megalkotásához, mint a fogalom két alapvető komponensét, elkülönítve vizsgálom az alkotmány és az identitás fogalmait. Az alkotmány fogalmának meghatározásakor először Deli Gergely munkássága nyomán az alkotmány természetét vizsgálom meg, majd a Petrétei József által alkalmazott rendszer szerint az alkotmány funkciót azonosítom, már az alkotmányos identitás és az európai integráció tükrében.

Kutatási előfeltevésem szerint az alkotmányos identitás természete a két fogalmi komponens, majd azok kapcsolatának elemzésével érthető meg a legteljesebben, ezért az alkotmány fogalmának vizsgálata mellett elkülönülten vizsgálom az identitás és identitásképzés szociálpszichológiai fogalmát, amelyhez Bodó Barna és Erik H. Erikson munkásságát választottam. Teszem mindezt azon kutatási előfeltevésem igazolása érdekében, amely szerint a természetes személyek identitásképzésének folyamata során megvalósuló mechanizmusok - mutatis mutandis - alkalmazhatóak az államok, alkotmányos rendszerek identitásképzésének folyamata során is.

Az alkotmányos identitás kialakulásában szerepet játszó tényezők azonosítása és egymáshoz füződő viszonyuk vizsgálata után értekezésemben Jacobsohn és Rosenfeld munkásságát kiindulópontként használva bemutatom az (alkotmányos) identitásképzés folyamatát és az annak során ható törvényszerüségeket. Ez alapján pedig - már tekintettel a dolgozat második fö logikai részére, a szupranacionális térre - megvizsgálom a jogtudomány által alkalmazott terminológiákat, amelyek - álláspontom szerint egységesen az alkotmányos identitás koncepcióját kívánják azonosítani. Kutatási előfeltevésem szerint a nemzeti alkotmányos identitás és a tagállami identitás fogalmak olyan jelenségekre utalnak, amelyek azonosíthatók az alkotmányos identitás koncepciójával, azonban tényleges szükítést, vagy kiterjesztést nem tartalmaznak, ezért alkalmazásukat a modellalkotás során mellőzöm.

Az identitásképzés modelljének megalkotását követően a fogalmi rendszer meghatározásának utolsó eleme az EUSZ 4. cikk (2) bekezdés első fordulat által alkalmazott nemzeti identitás fogalma. Az értekezés koordináta-rendszere, amelyben a vizsgálatot lefolytatom az európai szupranacionális tér, ezért az EUSZ hivatkozott rendelkezését a szupranacionalitásból fakadó sajátos elvek és törvényszerüségek, illetve az alkotmányos paradoxon bemutatását követően az európai integrációról szóló második 
fö részben (III. és IV. fejezetek) vizsgálom az EUB és a tagállami alkotmánybíróságok gyakorlatára (is) tekintettel. A modellalkotás tehát az alkotmányos identitás fogalmának elemzésével zárul.

Az EUSZ által alkalmazott nemzeti identitás fogalma, illetve az általam megalkotott modellt tekintve inkonzisztencia mutatható ki a nemzeti identitás fogalmának tartalmát illetően, amely megjelenik egyúttal a tagállami alkotmánybíróságok gyakorlatában is: nevezetesen az EUSZ által alkalmazott nemzeti identitás fogalmat - tartalmában - a tagállami alkotmánybíróságok és a jogtudományban fellelhető álláspontok jelentős része az alkotmányos identitás fogalmával azonosítja. Kutatási előfeltevésem szerint az EUSZ által alkalmazott nemzeti identitás fogalom tartalmában megfeleltethető a jogtudomány és a tagállami alkotmánybíróságok által alkalmazott alkotmányos identitás fogalommal és elkülönítendő az identitásképzés modelljében azonosított nemzeti identitás fogalomtól. ${ }^{44} \mathrm{~A}$ fenti relációt és az alkotmányos identitás fogalmával ekvivalens tartalmú terminológiákat a 2. sz. ábra szemlélteti.

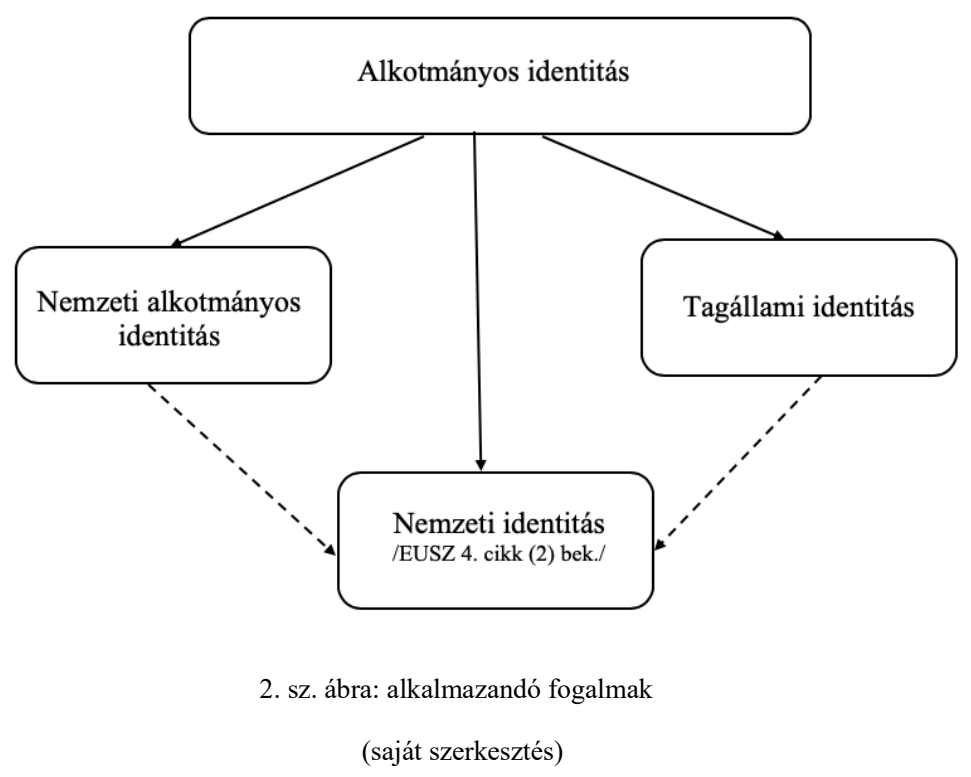

$\mathrm{Az}$ értekezés második fő része az alkotmányos identitás megjelenését és alkalmazhatóságát vizsgálja az európai integráció relációjában. A második fő részben az identitásképzés modelljét kiterjesztem a szupranacionális berendezkedésről és az

\footnotetext{
${ }^{44}$ Az EUSZ megszövegezésekor vélhetően szándékosan került mellőzésre az „alkotmányos” jelző, illetve a Maastrichti Szerződés megalkotásakor az alkotmányos identitás koncepciója még csak korai állapotában járt, így a fogalmi inkonzisztencia problémája fel sem merülhetett. Már a megszövegezéskor is problémát kellett, hogy jelentsen azonban a nemzeti identitás széles társadalomtudományi értelmezése, illetve az Uniós kontextustól eltérő alkotmánybírósági gyakorlat.
} 
alkotmányos paradoxonról szóló fejezetben tett megállapításokra tekintettel az európai integráció egészére. Kutatási előfeltevésem szerint az integráció szupranacionális jellege szükségessé teszi az alkotmányos identitás külső és belső oldalának elkülönítését, hasonlóan a szuverenitás külső és belső oldalához. Az alkotmányos identitás belső oldalát az örökkévalósági klauzulák tükrében vizsgálom. Kutatási előfeltevésem, hogy azok a tagállamok, melyek alkotmányaikban örökkévalósági klauzulát alkalmaznak, ezzel alkotmányos berendezkedésük olyan inherens, belső magját kívánják védelemben részesíteni, amely egyúttal alkotmányos identitásuk részét is (a német szövetségi alkotmányíróság szóhasználatával élve „forrását”) képezi.

Az örökkévalósági klauzulák azonban az alkotmányos alanyon, a tagállamon „,belül” képesek védelemben részesíteni az alkotmányos berendezkedés e meghatározó, fundamentális elveit, illetve értékeit. ${ }^{45}$ A szupranacionális környezet jellegzetességéből fakadóan azonban az integráció mélyülésével - és különösen érdekközösségből értékközösséggé válásával - ezek a fundamentális, az alkotmányos rendszert meghatározó intézmények, elvek, illetve értékek nem csak az alkotmányos alanyon „,belülről” válhatnak érintetté: az EUB következetes joggyakorlatának tükrében egy tagállam nem hivatkozhat nemzeti alkotmányának rendelkezéseire az uniós joggal szemben. Kérdésként merül fel, hogy az uniós jogrendben milyen mechanizmus hivatott védelemben részesíteni a tagállamok alkotmányos berendezkedésének ezen fundamentális, számos esetben értéktartalommal bíró elveit, intézményeit, illetve alkotmányi rendelkezéseit? A választ az EUSZ 4. cikke hordozza, amely az Unió kötelezettségévé teszi a tagállamok nemzeti identitásának tiszteletben tartását, vagyis - a korábbiak szerint - alkotmányos identitásának védelmét, determinálva egyúttal a tagállami alkotmányos identitás külső oldalát.

Az EUSZ 4. cikk (2) bekezdés értelmezése azonban számos nehézségbe ütközik, ezért értekezésemben vizsgálom az értelemzés egyes lehetőségeit is. Kutatási előfeltevésem szerint az EUSZ 4. cikk (2) bekezdésének első és második fordulatát egymásra tekintettel, de egymástól elkülönülten kell értelmezni. Az első fordulat tartalmazza a szoros értelemben vett identitás-klauzulát, amely a tagállamok alkotmányos berendezkedésének

${ }^{45}$ Az alkotmányos identitás belső oldalának megtestesülése nem csak az örökkévalósági klauzulák által képzelhető el. Ilyen belső megjelenési forma például a történeti alkotmány vívmányairól szóló alaptörvényi klauzula vagy a francia alkotmányos blokk, amelyről bővebben lásd: Trócsányi 1989, pp. 116-117. 
egyedi elemeit hivatott védelemben részesíteni: a tagállami alkotmányos berendezkedések azon intézményeit, alkotmányban rögzített értékeit, amelyek kizárólag az adott alkotmányos berendezkedés - történelmi fejlődés eredményeként létrejövő egyedi jellemzőiként tekintendők (Pl. laicitás - Franciaország, történeti alkotmány vívmányai $^{46}$ - Magyarország, köztársasági államforma és emberi méltóság Németország, stb.).

Ezzel szemben a második fordulat szerint az Unió a tagállamok alapvető állami funkcióit kell, hogy tiszteletben tartsa. Az alapvető állami funkciók meghatározása olyan generális, a tagállami szuverenitáshoz kötődő kérdés, amely valamennyi tagállamra általánosan vonatkozik. Az EUSZ 4. cikkének értelmezése során kitérek az EUB gyakorlatának vizsgálatára a szükséges mértékig, azonban teszem ezt a joganyag jogtudományi feldolgozottságára tekintettel, így számos esetben már a klauzula vizsgálata során hivatkozom a jogtudomány hazai és nemzetközi képviselőinek, az EUB gyakorlatát részletesen feldolgozó és bemutató munkásságára.

Az alkotmányos identitás uniós alkalmazási területeinek feltérképezése során az EUSZ 4. cikkének vizsgálatát követően az alapvető jogokon, illetve a nemzeti alkotmánybíróságok gyakorlatán keresztül bemutatom az alkotmányos identitás tartalmára vonatkozó főbb tagállami gyakorlatot, külön alfejezetet szentelve a magyar Alkotmánybíróság által kialakított gyakorlatnak, illetve a Német Szövetségi Alkotmánybíróság PSPP döntésének.

Értekezésem záró részét - a kutatási előfeltevéseim igazolását, illetve elvetését megelőzően az (alkotmányos) identitásképzés modelljén keresztül megvizsgálom az európai integráció alkotmányos alanyiságát, illetve egy európai (alkotmányos) identitás kialakulásának lehetőségét, illetve akadályait.

Értekezésem elkészítése során elsősorban az összehasonlító alkotmányjog, a nyelvtani és rendszertani értelmezés, a történeti és teleologikus értelmezés, illetve a modellalkotás ${ }^{47}$ módszereire támaszkodtam. Célom az alkotmányos identitás természetének lehetőség szerinti feltárása, illetve az identitásképzés folyamatának modellezése volt, majd ennek

${ }^{46}$ Vö.: 22/2016. (XII. 5.) AB határozat, illetve Fejes 2015, pp. 36-41.

${ }^{47}$ Vö.: Mankiw 2011, pp. 24-27. 
alapján annak megállapítása, hogy az európai integráció szupranacionális jellege hogyan befolyásolja az identitásképzési folyamatot. A feltárt eredményekre, illetve az elkészített modell(ek)re tekintettel végig törekedtem egy koherens fogalmi rendszer megteremtésére, illetve alkalmazására. 


\subsection{Az alkotmányos identitás fogalmának eredete}

Az alkotmányos identitás fogalma a jogtudományban elöször Németországban jelent meg 1928-ban Carl Schmitt és Carl Bilfinger munkássága nyomán az alkotmánymódosítás lehetséges korlátaival, illetve az alkotmányellenes alkotmánymódosítással összefüggésben. ${ }^{48}$ Az európai joggyakorlatban a Német Szövetségi Alkotmánybíróság alkalmazta elöször a fogalmat az azóta is az alkotmányos identitás európai koncepciójának egyik meghatározó állomásaként számon tartott Solange I. döntésében. ${ }^{49}$ $\mathrm{Az}$ Európai Unió jogrendjében az Alapító Szerződések szintjén a Maastrichti Szerződéssel jelent meg, mint a nemzeti identitás tiszteletben tartásának uniós kötelezettsége. ${ }^{50}$

Az angolszász és az európai jogfejlődés tekintetében elváltak egymástól a fogalom kontextusai és így eltérő tartalommal jelenik meg az angolszász és a kontinentális jogi gondolkodásban. ${ }^{51}$

(i) Az angolszász irányzatban a joggyakorlat és a jogtudomány felfogása azonos irányba mutat és a fogalom értelmezése megmaradt a Carl Schmitt által alkalmazott eredeti kontextusában: az alkotmányellenes alkotmánymódosítás, illetve az alkotmány módosíthatóságának korlátjaként. ${ }^{52}$ (Megjegyzendő, hogy Jacobsohn az alkotmányos identitást, mint az alkotmányos rendszer (berendezkedés) természetét fogja fel és eredetét Arisztotelészig vezeti vissza. ${ }^{53}$ )

(ii) A kontinentális felfogásban jelentős eltérések mutatkoznak a koncepció eredeti tartalmához képest. A változás az európai integráció kialakulásának törvényszerü következménye, amely alapjaiban határozta meg az európai értelmezés fejlődésének irányvonalát. A kontinentális értelmezésben jelentős eltérések mutatkoznak a jogtudomány és a joggyakorlat álláspontja között, azzal a megjegyzéssel természetesen, hogy a tö, amelyröl mindkét

\footnotetext{
${ }^{48}$ Polzin 2016, pp. 415-421.

${ }^{49}$ Polzin 2016, p. 426.

50 Vö.: Orbán 2018, p. 1., illetve Drinóczi 2018a, p. 1. A fogalomhasználattal, illetve a klauzula megjelenésével és értelmezésével részletesen jelen értekezés 2.5.3., illetve 4.1. fejezetei foglalkoznak.

${ }^{51}$ Bövebben lásd: Polzin 2016, illetve Polzin 2017, pp. 1596-1604.

52 Vö.: Jacobsohn 2010, pp. 34-84.

${ }^{53}$ Vö.: Jacobsohn 2010, pp. 2-33.
} 
megközelítés fakad, egy és ugyanaz: az európai integráció jogrendjének és a tagállami alkotmányoknak a kapcsolata.

Az alkotmányos identitás európai értelmezésének célja, hogy az integrációs folyamatok medrén belül, annak tiszteletben tartásával kísérletet tegyen az európai jogrend égiszén belül a tagállami alkotmányos berendezkedések által hordozott egyediség, alkotmányi értékek, alkotmányos elvek és intézmények védelmére. A fogalom hatásának és használatának elmúlt években, évtizedekben tapasztalt felerősödése azonban nem csak a fenti kapcsolat meghatározása iránti igény következménye.

Az európai szupranacionális jogrend újkeletü, sajátos intézmény, amely természetéből fakadóan hívott életre egy alkotmányos paradoxonként nevesíthető ${ }^{54}$ anomáliát, amelynek központi problémája a tagállami alkotmányok és szuverenitás, illetve az uniós jogrend kapcsolata. Az alkotmányos paradoxon által generált feszültség és alkotmányos instabilitás pedig törvényszerüen vonta maga után a tagállamok alkotmányos identitás védelme iránti igényét, téve ezáltal azt a szupranacionális berendezkedés tulajdonságává. Kérdés azonban, hogy a jelenleg formálódó tudományos és gyakorlati vitákban helyesen értelmezzük-e a fogalom gyakorlati alkalmazhatóságát és jelentőségét?

\footnotetext{
${ }^{54}$ Blutman-Chronowski 2007, p. 3.
} 


\section{Fogalommeghatározások és elhatárolások}

\subsection{Jogelméleti alapok és az identitásképzés modellje}

Az alkotmányos identitás fogalmának európai értelmezése magán hordozza - és a jövőben még inkább magán fogja hordozni - az európai integráció sajátos természetéböl fakadó jegyeket. Ugyanakkor úgy vélem, hogy az európai értelmezés során érdemes, sőt szükségszerü az elmélet eredetéig visszanyúlni és megvizsgálni többek között az alkotmányos identitás angolszász értelmezésének jogelméleti alapjait: az alkotmányos identitás fogalmának komplexitása a két fogalmi komponens egymásra vonatkoztatásából ered.

Az identitás szociálpszichológiai fogalmából következő mechanizmusokat kell alkalmaznunk az alkotmányjog koordináta rendszerében, majd ezt európai kontextusban ki kell egészítenünk a szupranacionális berendezkedés által életre hívott többlet elemekkel. Értekezésemben az identitásképzés olyan modelljének megalkotására törekszem, amely minden egyéb tényező változatlanul, illetve figyelmen kívül hagyása mellett az alkotmányos identitás kialakulására, az ahhoz szükséges, illetve abban közreható tényezőkre koncentrál. Az identitás e - jogelméleti alapokon nyugvó modelljét alapul véve törekszem később egy koherens fogalmi rendszer kialakítására.

Jogelméleti szempontból az angolszász gondolkodók közül Rosenfeld ${ }^{55}$ és Jacobsohn ${ }^{56}$ munkássága átfogónak tekinthető. ${ }^{57}$ Rosenfeld Hegel filozófiájáig nyúlik vissza és az alkotmányos identitás meghatározását megelőzően - kvázi előfeltételeként - az identitást hordozó entitást határozza meg, amelyet teóriájában , constitutional self”-ként nevesít. ${ }^{58}$ Ahogyan azt a későbbiek során látni fogjuk, Rosenfeld és Jacobsohn elméleteinek eredőjeként állapítható meg, hogy az alkotmányos identitás hordozója kizárólag a

\footnotetext{
55 Vö.: Rosenfeld 2010

${ }^{56}$ Vö.: Jacobsohn 2010

${ }^{57}$ Szükséges megjegyezni azonban, hogy Michel Rosenfeld hivatkozott - és egyéb - műveiben az egyes európai alkotmányos rendszerek berendezkedését, sőt magát az európai integrációt is vizsgálja az alkotmányos identitás szemszögéből ezért Rosenfeld nem tekinthető tisztán az angolszász szemléletmód képviselőjének, munkáiban az alkotmányos identitást összehasonlító alkotmányjogi értelmezésben globális szinten vizsgálja.

${ }^{58}$ Rosenfeld 2010, pp. 37-38.
} 
„,constititional self” lehet, amelyet jelen értekezés során alkotmányos alanyként nevesítek.

A Rosenfeld által megalkotott alkotmányos alany Jacobsohn tételeit alapul véve megfeleltethető az alkotmányos rendszerrel, amelyet az európai terminológiában leginkább alkotmányos berendezkedésként azonosíthatunk. ${ }^{59} \mathrm{Ez}$ nem más, mint a népszuverenitásból fakadóan a politikai nemzetet alkotó nép, a nép által felruházott alkotmányozó hatalom és az alkotmányozó hatalom letéteményesei által létrehozott alkotmány egymásra hatásaként létrejövő struktúra, amely egyszersmind szuverenitással rendelkező, önálló entitásként értelmezendő. ${ }^{60} \mathrm{E}$ jogelméleti alapvetés különösen megfontolandó az identitás európai értelmezése során, mivel a kontinentális felfogásban ezidáig az alkotmányos identitásra irányuló értekezések nem egységesek a tekintetben, hogy az identitást maga az alkotmány, a politikai nemzet, vagy az alkotmányos rendszer (berendezkedés) hordozza-e ${ }^{61}$, illetve nincs egységesen elkülönült fogalomrendszer sem, amely konzekvensen elkülönítené a nemzeti identitást, az alkotmányidentitást és az alkotmányos identitást. Egyelőre tehát nem tünik meghatározottnak, hogy az alkotmányos identitás pontosan minek is az identitása. ${ }^{62}$

Míg az angolszász jogirodalomban ${ }^{63}$ az alkotmányos identitás doktrínája alapvetően jogelméleti (alkotmányelméleti) kategória, addig az európai integrációban a hangsúly a gyakorlati alkalmazhatóságon, illetve a tagállami alkotmányok és az uniós jog összeütközése esetén a felhívhatóságon van. Ma, a tagállamok és az európai integráció közötti feszültség kiéleződésének időszakában, a tagállamok a hangsúlyt az alkotmányos identitás tartalmi, gyakorlati kérdéseire fektetik:

(i) Mit jelent az egyes tagállamok alkotmányos identitása és ezekre hogyan és milyen mértékig hivatkozhatnak?

(ii) Mit jelent, hogy az Európai Unió tiszteletben tartja a tagállamok nemzeti identitását? Jelentheti-e az alkotmányos identitás azt a határmezsgyét, amely

\footnotetext{
${ }^{59}$ Vö.: EUSZ 4. cikk (2) bek. első fordulat, mint későbbi elemzés tárgya.

${ }^{60}$ Rosenfeld 1995 és Jacobsohn 2013, pp. 5-16.

${ }^{61}$ Vö.: Sulyok 2016b, Marty 2013, pp. 21-30.

${ }^{62} \mathrm{Az}$ identitás minden esetben az azt létrehozó entitáshoz kötődik. Lásd később.

${ }^{63}$ Lásd Jacobsohn és Rosenfeld hivatkozott és egyéb műveit.
} 
az európai integráció specifikumának tekinthető szuverenitástranszfer korlátját képezi?

(iii) Alkalmas-e az alkotmányos identitás annak dinamikus körülhatárolására, hogy a tagállamok a szuverenitástranszfer folytán az állami szuverenitásból fakadó egyes jogköreiket meddig és milyen mértékben ruházhatják át az Európai Unióra?

(iv) Ki határozhatja meg - vagy sokkal inkább nyilváníthatja ki! - az egyes tagállamok alkotmányos identitását?

(v) Milyen kapcsolat füzi össze a kérdés megválaszolásában az EUB-t és a tagállami alkotmánybíróságokat?

Úgy vélem ahhoz, hogy az alkotmányos identitás válaszokkal szolgálhasson a tagállamok és az integráció viszonyában felmerülö fenti kérdésekre, szükséges az alkotmányos identitás jogelméleti alapjainak megértése és meghatározása az európai szupranacionális térben (is), hogy az alkotmányos identitás sziklára, és ne homokra épített házként az integráció stabilizálódását és ne destabilizálódását mozdítsa elő, híd legyen az integráció és a tagállamok között ahelyett, hogy a fennálló feszültségeket eszkalálva szakadékot képezzen.

Az alkotmányos identitás elméleti modelljének kialakításához, illetve a koncepció mögött húzódó jelenség megértéséhez a fogalmat - korábban ismertetettek szerint - két megközelítésből, a két komponens irányából szükséges vizsgálni. Bár az alkotmányos identitás kialakulásának folyamatában a mechanizmus forrása az alkotmányos közösség, illetve az alkotmányos alany, a vizsgálatot mégis az identitás-fogalom ismertetésével kezdem, tekintettel arra, hogy az itt meghatározott kölcsönhatások irányadóak lesznek valamennyi fogalmi elem későbbi definiálása során is. 


\subsection{Az identitás-fogalom}

$\mathrm{Az}$ identitás legelemibb értelmezésében azonosságot, lényegi egyformaságot jelent. Filozófiai szempontból ,az a logikai törvény, amely szerint minden fogalomnak adott időben és vonatkozásban önmagával azonosnak kell lennie. Jelenti továbbá az önmagunkkal, vagy valamely csoporttal való azonosulás érzését is. "64 Az identitás vagy önazonosság eredendően szociálpszichológiai fogalom, amely egy adott személy önmeghatározásának kérdéseit vizsgálja a társadalom függvényében. ${ }^{65} \mathrm{~A}$ fogalomból eredő identitásformálási mechanizmusok azonban leképeződnek az alkotmányos identitás esetében is, ezért a szükséges mértékig megkísérlem az identitás fogalmából eredő releváns folyamatok bemutatását, amelyhez kiindulási alapként Bodó Barna szociológus munkásságát választottam. ${ }^{66}$

Az identitás vizsgálata során nem pusztán az identitás adottságként való felfogásáról, hanem annak dinamikus, interaktív folyamatként történő értelmezéséről beszélhetünk. E szerint az identitás soha nem ,valamilyen teljes és befejezett meghatározottság”. Bodó, Erik H. Erikson tételeiből kiindulva, ${ }^{67}$ az identitásban az önmagáról gondolkodó egyén azon kísérletét látja, hogy én-tudatának nevet adjon a kultúrában, azaz nevesítse azon faktorokat, amellyel eltér, vagy éppen megegyezik más személyekkel. ${ }^{68}$ Ezen kívül Bodó megjegyzi: az identitás nem lehet eleve adott, identitását mindenkinek állandóan és folyamatosan kell felépítenie. ${ }^{69}$

Az identitás nem pusztán az emberhez, mint egyénhez, individuumhoz kötődik. Személyek valamely struktúra szerint szervezett csoportja a külvilág szempontjából szintén önálló entitásként viselkedhet, és mint ilyen, kollektív identitással rendelkezhet. ${ }^{70}$ Következésképpen nem csak a közösség egyes, elkülönült tagjainak azonosíthatók identitáselemei, de a közösséget alkotók valamely tulajdonság szerinti homogenitásából fakadóan modellszerü identitásminták is azonosíthatók, amelyek már nem kizárólag a

\footnotetext{
${ }^{64}$ Pusztai 2014, 553. p.

65 Vö.: Pataki 1997a, pp. 321-330.

${ }^{66}$ A kérdéskör bővebb vizsgálatát lásd: Bodó 2004.

67 Megjegyzést érdemel, hogy Jacobsohn az identitás fogalmának vizsgálata során szintén Erikson definícióját veszi alapul. Vö.: Jacobsohn 2010, pp. 9-10.

68 Bodó 2004, p. 13.

69 Bodó 2004, p. 15. A másokkal való kölcsönhatásban (dialogikusan) történő identitás-építés pedig egyértelműen rezonál az alkotmányos párbeszéd és alkotmányos identitás közötti összefüggésekre.

${ }^{70}$ Pataki 1997a, p. 326.
} 
kollektívát alkotó egyének önálló tapasztalatain alapulnak. A közösség identitása a kollektív tapasztalás, a kollektív identitásképzés eredménye. ${ }^{71} \mathrm{E}$ jelenség alapján beszélhetünk vallási, kulturális, nemzeti, stb. identitásról és így alkotmányos identitásról is. $^{72}$

A lényeg a külvilág irányába megjelenő egységben mutatkozik. Habermas szerint a kollektív identitások esetén az azokat alkotó én-struktúrák univerzalizálódásának, illetve a kollektív identitás dominánsabbá válásának jelensége figyelhető meg. ${ }^{73}$ Ebből kiindulva pedig elmondható, hogy a kollektív identitás, amely az azt létrehozó entitások (legyenek azok egyének, közösségek, vagy az alkotmányos identitás esetén az államok) egységes akaratából jön létre, visszahat a létrehozó entitások önazonosságára, azaz szükségszerüen formálja is azokat. ${ }^{74}$ Habermas vonatkozó tételei sorában említi, hogy „a jövő kollektív identitása nem lehet más, mint az identitáskonstruálás formális feltételeire vonatkozó, folyamatosan és kommunikatív struktúrák révén elöállt konszenzus." 75

Bodó - különböző identitáselméletek ismertetése körében ${ }^{76}$ megfogalmazott megállapításait az alkotmányos identitás vizsgálatára kivezetve a következőket szükséges említeni:

(i) az általa ismertetett szociálpszichológiai elméletek mindegyike egy „szubjektumot” állít a kiindulópontba, amely kialakítja saját identitását.

(ii) A kollektív identitásképzés esetén az identitást hordozó entitás a kollektív szubjektum, amely nem más, mint a csoportot alkotó egyének közös jellemzőinek kifejeződéseként létrejövő kollektíva, amelynek tagjai egységet alkotnak és amelynek identitása „a csoport társadalmi feltételeiből, történeti fejlödéséböl s a csoportot alkotó egyéneknek ebben a sajátos konkrét közegben lezajló egyöntetü szocializálódásából" fejlődik ki. ${ }^{77}$

Az identitás tehát minden esetben kötődik valamely szubjektumhoz (entitáshoz). A szubjektum számára az identitás kialakítása a többi szubjektumtól való különbözőség

\footnotetext{
${ }^{71}$ Uo.

${ }^{72}$ Amelynek azonban lehetnek természetesen vallási, kulturális, nemzeti, stb. elemei is.

${ }^{73}$ Vö.: Habermas 1994, p.141-182.

${ }^{74}$ Habermas 1994, pp.145-148, 149-154.

75 Idézi Bodó Habermast: Bodó-Toró 2011, p. 20., illetve Habermas 1976, p. 121.

${ }^{76}$ Bodó 2004, p. 40.

${ }^{77}$ Vö: Pataki 1997b, p. 305.
} 
kinyilvánítása miatt szükséges önmaga, és a többi szubjektum számára, ugyanakkor e folyamat visszahat a szubjektum „én-képére” és így szükségszerüen meg is határozza a kialakított identitást. ${ }^{78}$ (A szubjektum, vagyis az identitást képező, majd hordozó entitás az alkotmányos identitás kontextusában megfeleltethető a későbbiek során bemutatott és Rosenfeld nevéhez köthető constitutional self-el, az alkotmányos alannyal.)

Az identitás azonban nem (csak) egy adott időpontban meghatározott tényezők összessége, sokkal inkább a szubjektum létezése (fennállása) óta, a szubjektumot lényegileg meghatározó tényezők által meghatározott összesség, amelyet az adott időpontban csupán értelmezünk ${ }^{79}$ és amely az identitásnak egyszerre kölcsönöz statikus és dinamikus jelleget. ${ }^{80}$

Annak érdekében, hogy az alkotmányos identitás vizsgálata során alkalmazható legyen, a Bodó által alkotott identitás-fogalmat két ponton szükséges kiegészíteni:

(i) Egyrészről, ha az identitásképzés feltétele az önmagáról gondolkodó entitás szubjektum - azon igénye, hogy önmagát másoktól megkülönböztesse, akkor az identitásképzésre nem pusztán az egyén, hanem bármely önálló entitás képes. Számára pedig létezéséből adódóan szükségszerü, hogy megkülönböztesse önmagát másoktól.

(ii) Másrészről az én-tudat értelmezése nem pusztán a kultúrában képzelhető el, hanem bármely, az adott entitást meghatározó közegben. Ezek alapján az identitás az önálló szubjektumot meghatározó azon jelenségként fogható fel, amellyel az önmagáról gondolkodó entitás megkísérli, hogy öntudatának nevet adjon az öt meghatározó közegben, önmagát a hozzá hasonlóktól megkülönböztesse, ti. nevesítse azon faktorokat, amelyek miatt eltér más szubjektumoktól, vagy éppen azokkal megegyezik.

\footnotetext{
78 E következtetés lényegében megegyezik a későbbiek folytán ismertetett hegeli filozófia tételeivel, amelyből Rosenfeld kiindul az alkotmányos identitás vizsgálata során, illetve a habermasi tételekkel is.

${ }^{79}$ E körben szükséges megjegyezni, hogy e megállapítás párhuzamba állítható a történeti alkotmányok alkotmányjogi fogalmával, melyek szintén összeforrnak a nemzet történelmével és azzal organikusan fejlődnek, ugyanakkor Rosenfeld a brit alkotmányos modell elemzése során bemutatja, hogy a tény, hogy egy államnak nincs kartális alkotmánya, nem befolyásolja az alkotmányos identitás természetét, pusztán meghatározza annak megnyilvánulását. Bővebben lásd: Rosenfeld 2010, pp. 163-169. Magyarország tekintetében az Alkotmánybíróság a 22/2016. (XII. 5.) AB határozatban a történeti alkotmány vívmányait Magyarország alkotmányos önazonossága körében nevesíti.

${ }^{80}$ Vö.: Sulyok 2014, pp. 44-46.
} 


\subsection{Az alkotmányos alany: közösség - alkotmány - struktúra}

Az identitás fogalmának vizsgálata során jelentkező szubjektumot az alkotmányosság koordináta-rendszerében értelmezve, az megfeleltethető az alkotmányos alannyal, amely a későbbiekben kifejtett rosenfeldi logika mentén az alkotmányos identitás hordozójává válik. Rosenfeld rendszerében az alkotmányos alany egyfajta perszonifikációs (megszemélyesítési) fejlődési folyamat során ,alkotmányos énné” alakul át.

Rosenfeld az alkotmányos pluralizmus (constitutional pluralism) elmélet kidolgozása során Hegel filozófiájából indul ki, amely szerint egy személy természetéből fakadóan követeli meg, hogy a vele kapcsolatba kerülő más személyek elismerjék, illetve azoktól megkülönböztethetővé váljon. ${ }^{81}$

Rosenfeld Hegelre hivatkozással kifejti ugyanakkor, hogy amikor ez megtörténik, a konfrontációval egy idöben törvényszerüen elkezdődik egyfajta dominanciáért vívott harc. ${ }^{82}$ Rosenfeld szerint az identitással rendelkező alkotmányos alany kérdésköre abból a szükségletből emelkedik ki, hogy két alkotmányos entitás egymással való kapcsolatba kerülésekor - a hegeli logika folytán - konfrontálódik. ${ }^{83}$ Az alkotmányos alany perszonifikációjának folyamatát elemezve Rosenfeld a pszicho-analitika módszertanához folyamodik és a Jacques Lacan által kidolgozott tételeket hívja fel, aki szerint egy formálódó személyiség saját identitását a többi személyiséghez füződő kapcsolatában értelmezi ${ }^{84}$, önmagát a vele kapcsolatba kerülő személyekhez viszonyítva határozza meg és identitásának egyes jegyeit is e kapcsolatokból nyeri. ${ }^{85}$

A rosenfeldi logika mentén összegezhető, hogy az önálló alkotmányos alany önmagát minden más alkotmányos alanytól megkülönböztetendő, a velük való konfrontációban saját, egyedi tulajdonságai, identitásjegyei alapján - egyfajta perszonifikációs folyamat révén alkotmányos önazonossággal rendelkezővé - ,alkotmányos énné” - alakul át; azaz

\footnotetext{
${ }^{81}$ Az alkotmányos pluralizmus elmélete az alkotmányos önazonossággal rendelkező alkotmányos alanyok saját belső, illetve egymás közötti viszonyának rendezésében áll. Ehhez bővebben ld. Rosenfeld hivatkozott müveit.

${ }^{82}$ Rosenfeld 2010, p. 37. A hegeli filozófia vonatkozó tételeit bővebben lásd: Hegel 1961.

${ }^{83}$ Rosenfeld 2010, p. 38.

${ }^{84}$ Vö: Alkotmányos párbeszéd, mint identitáskeresés?

${ }^{85}$ Vö.: Lacan 1966, pp. 298-300, 655, 839-840.
} 
alkotmányos önazonosság kialakítására törekszik. (Rosenfeld e logikai fundamentumra építi fel mủvében a plurális alkotmányosság koncepcióját, lásd korábban.)

Hermeneutikailag az angol nyelvben használt „self” kifejezés jelentése: „egy személy alapvető, esszenciális lénye, amely megkülönbözteti őt másoktól, különös tekintettel az önvizsgálat tárgyára, vagy visszaható cselekvésre." ${ }^{86}$ (Ezért a Rosenfeld által alkalmazott constitutional self terminológiát leginkább is az „alkotmányos én” kifejezéssel határozhatjuk meg.)

A Rosenfeld által leírt fejlődési folyamat során az alkotmányos alanyok különböző jogi, politikai és társadalmi fejlődésen mennek át (alkotmányozási folyamatokból levont következtetések, politikai konfliktusok, válságok, etc. által), még elég kiforrottá válnak ahhoz, hogy megfogalmazzák alkotmányos identitásukat. Mint arra a korábbiakban már utaltam, Rosenfeld ugyanakkor megjegyzi, hogy az alkotmányos alany identitása mindennek ellenére megfoghatatlan, tételes körülhatárolása több problémát is felvet. Hivatkozik többek között az alkotmányos alany fogalmának többértelmüségére, miszerint nem feltétlenül határolható el egyértelmüen, hogy a fogalom az alkotmányos rendszert életre hívó és meghatározó közösségre, az alkotmányozó hatalom letéteményeseire, vagy az alkotmány tárgyára utal-e. ${ }^{87}$

Kiindulva az identitás-fogalom meghatározásakor lefektetettekből, illetve Rosenfeld elméleti alapjait összevetve Jacobsohn vizsgálódásaival, ${ }^{88}$ álláspontom az, hogy az alkotmányos alany nem különíthető el a Rosenfeld által felhívott egyik tényezőként sem. Ellenkezőleg: az alkotmányos alany e három alkotóelem (így az alkotmányos közösség, az alkotmányozó hatalom letéteményesei, és az alkotmány) kölcsönhatásából jön létre.

Az alkotmányt életre hívó politikai közösség, az alkotmányozó hatalom és maga az alkotmány (együtt alkotmányos rendszer) - és ezek kontinuitása - alkotja az alkotmányos alanyt. Jacobsohn alkotmányos diszharmónia elméletét ${ }^{89}$ összevetve Rosenfeld tételeivel, kijelenthetjük, hogy az alkotmányos identitást e három faktor egymással alkotott

\footnotetext{
${ }^{86}$ Deuter-Bradbery-Turnbull 2015, p. 1402., illetve: http://www.oxforddictionaries.com/definition/english/self

${ }^{87}$ Rosenfeld 1995, p. 1049.

${ }^{88}$ Vö.: Jacobsohn 2010

${ }^{89}$ Bövebben lásd: Jacobsohn 2013
} 
konfrontatív viszonyában létrejövő konszenzus határozza meg, amely konszenzust majd az alkotmányos politika síkján az alkotmányos berendezkedés erre hivatott intézményei szilárdítanak meg (ld. pl. bíróságok jogalkalmazásában). Az alkotmányos alany e szerinti összetételét a 3. sz. ábra szemlélteti. ${ }^{90}$

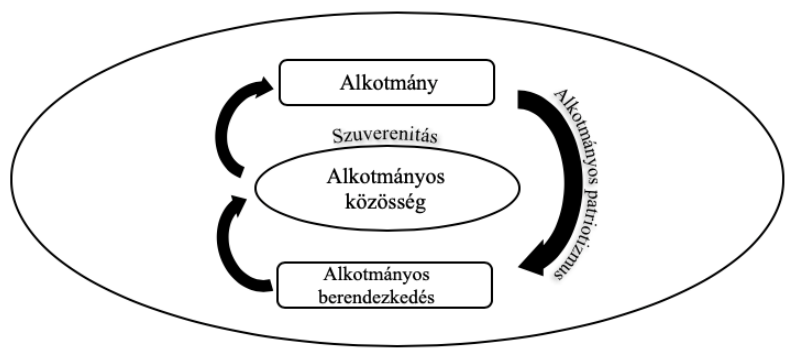

3. sz. ábra: az alkotmányos alany (saját szerkesztés)

${ }^{90}$ Jürgen Habermas alkotmányos patriotizmus elméletét bővebben lásd az értekezés 2.5.1. fejezetében. 


\subsection{Alkotmány és identitás}

A korábban ismertetettek szerint vizsgálatom felépítésének egyik szervező elvét egy triviálisnak tűnő megközelítés jelenti: az alkotmányos identitás fogalmának kétkomponensü összetétele. Alkotmány és identitás. Az egyes fogalmi komponensek egymásra vonatkoztatásán túl azok meghatározása és a belölük folyó törvényszerüségek is befolyással vannak magára a kapcsolatra, amelyből megszületik végül a maga koncepció. Kiemelendő azonban, hogy a két fogalmi komponens egymásra hatásából, az általuk megtestesített törvényszerüségek egymásra vonatkoztatott rendszeréből alakul ki az alkotmányos identitás és a fogalom nem azonosítható az alkotmány identitásával. Az identitás fogalmának elemzéséről szóló fejezetben meghatározottak szerint az alkotmányos identitás fogalmának természetét a kollektív identitásképzés határozza meg, az ennek forrásául szolgáló szubjektum pedig az alkotmányos közösség által létrehozott alkotmányos alany, amely azonban a közösség, az alkotmány és a kettő által determinált struktúra kölcsönhatásaiként születik.

Ezáltal az identitásképzés folyamatát az alkotmányos közösség által létrehozott alkotmányos berendezkedés alapjául szolgáló, egyúttal azt megtestesítő alkotmány hívja életre. Ezért az alkotmány vizsgálódásom következő pillére, mint az alkotmányos identitás fogalmának egyik forrása.

Vizsgálódásomat a III. fejezetében ismertetett szupranacionális jogrend sajátosságaira tekintettel folytatom le, hiszen az európai integráción belül ez jelenti azt a környezetet, amelyben a tagállamok nemzeti alkotmányai - és ezáltal alkotmányos identitásuk is léteznek. Ahogyan Csink Lóránt írja, az alkotmány soha nem a légüres térben létezik: elválaszthatatlan a társadalmi-politikai közösségtől, amellyel folyamatosan interakcióban van. ${ }^{91} \mathrm{Az}$ európai szupranacionális környezetben ez a társadalmi-politikai közösség már nemcsak az alkotmány „hatókörén” belül létező tagállami alkotmányos berendezkedést jelenti, hanem azt a környezetet is, amelyben a tagállam meghatározza önmagát.

Az alkotmányra vonatkoztatva mindezt, a szupranacionális jogrendben az alkotmány funkciói már nem csak „lefelé” hatnak az alkotmány által szervezett társadalom irányába,

\footnotetext{
${ }^{91}$ Csink 2015, p. 137.
} 
hanem közvetítő szerepet is betöltenek: biztosítják a közösségi jogrend viszonyát a nemzeti jogrenddel, ezáltal lehetővé teszik a közösségi jog normáinak adaptációját a nemzeti jogrendszerbe, vagyis megteremtik a tagállam integrációjának lehetőségét a közösséghez. Ez a folyamat azonban többet jelent eljárási szabályok összességénél: közösségi és alkotmányban foglalt értékek közvetítéséről, olykor transzformációjáról is szó van, amely kölcsönösen formálja magát az integrációt és a tagállamokat is. (Lásd a kollektív identitásképzés folyamatát.)

Mindezekre tekintettel először az alkotmányfogalom meghatározásával kezdem a vizsgálat ezen részét, elkülönítve az alkotmány általános meghatározását a jogi értelemben vett fogalomtól, majd az alkotmány funkcióinak változását már az értekezés harmadik, szupranacionális környezetről szóló fejezetében vizsgálom. 


\subsubsection{Az alkotmány általános értelemben alkalmazott fogalma}

Mikor az alkotmány fogalmát az alkotmányos identitás fent vázolt vizsgálati sémájában vagy arra alkalmazzuk, annak különböző szempontrendszerek szerinti eltérő meghatározásaira tekintettel tisztáznunk kell, hogy ezt milyen összefüggésben tesszük. ${ }^{92}$ Az alkotmány meghatározásának többféle (többek között tudományterületek szerinti) szempontrendszere ismert ${ }^{93}$, amelyek közül jelen értekezés keretei között az általános értelemben felfogott megközelítést és a jogi értelemben alkalmazott alkotmányfogalmat vizsgálom.

Mivel általános értelemben az alkotmány valamely tartós emberi közösségi alakzatnak az állapotát, felépítettségét és rendezettségét ${ }^{94}$, vagyis a szabályozott társadalmi rendet jelenti, ezért vizsgálni szükséges az általános megközelítésböl levonható következtetéseket az európai integráció vonatkozásában is. Ugyan az Európai Unió nemzetközi szerződésen alapuló nemzetközi szervezet, ugyanakkor a szupranacionalitás révén rendelkezik azzal a képességgel, hogy tagállamait azok akarata ellenére is meghatározott cselekvésre kötelezheti, ${ }^{95}$ következésképpen közvetlen hatást gyakorol(hat) azok társadalmi berendezkedésére.

Az általános megközelítés azonban könnyen alkotmány- és államelméleti dimenziókba terelheti a gondolatmenetet, hiszen rövid logikai ugrással felmerül az örökzöldnek tekinthető kérdés: rendelkezhet-e az Európai Unió alkotmánnyal, alkotmányi funkciót töltenek-e be az Alapító Szerződések, stb. ${ }^{96}$ Amennyiben tehát a tételes jog (uniós és nemzeti jog viszonya) szempontjából gyakorlatiasabb és megfoghatóbb szempontrendszer szerint kívánjuk vizsgálni az alkotmány(ok) jelentőségét, úgy a jogi értelemben vett meghatározást kell vizsgálnunk és abból a jelen összefüggések között következtetéseket levonnunk. Ez a lehatárolás egyúttal közelebb vihet egy, az alkotmányos identitás vizsgálata körében felmerülő fogalmi distinkció problémájához is,

\footnotetext{
92 Petrétei 2011, p. 47.

${ }^{93}$ Vö.: Takács 2007, pp. 21-23., Petrétei 2011, pp. 47-49., Möllers 2011, pp. 5-10., Deli 2018, stb.

${ }^{94}$ Petrétei 2011, p. 47.

95 Vincze-Chronowski 2018, p. 21.

${ }^{96}$ Vö.: Möllers 2011, pp. 10-24. A kérdést jelen értekezés második részében részletesebben is vizsgálom.
} 
ti. hogy az alkotmányos identitás az alkotmány identitását jelenti-e, vagyis azonosíthatóe az alkotmányidentitás fogalmával. ${ }^{97}$

Ha ugyanis az alkotmány általános fogalmából indulunk ki, amely esetben alkotmány alatt a szabályozott társadalmi rendet értjük, akkor annak identitása, mint az alkotmányos rendszer (berendezkedés) identitása lényegében megfeleltethető az alkotmányos identitás fogalmával. Amennyiben azonban az alkotmány jogi fogalmát tekintjük irányadónak, úgy megváltozik az identitást hordozó szubjektum és a jogi értelemben vett alkotmány identitását (vagyis az alkotmányidentitást) illetve az alkotmányos rendszer (berendezkedés) identitását eltérő tényezők határozzák meg. A kérdés eldöntése tehát függ a nézőponttól, ahonnan az alkotmányos identitás fogalmának értelmezésekor az alkotmány fogalmát megközelítjük.

Az alkotmány általános értelemben a társadalmi együttélés jogilag szabályozott rendje, melynek azonban meg kell felelnie az alkotmányosság követelményei által támasztott kritériumoknak. ${ }^{98}$ Deli Gergely szerint alkotmányon olyan egységes és önmagában megálló rendet értünk, amely tartalmazza az emberi együttélést megalapozó két megegyezést: egyrészt az emberek egymás közötti egyesülését, másrészt az államnak történő alávetésüket. ${ }^{99}$ Alább az alkotmány általános fogalmával csak egy szük aspektusból kívánok foglalkozni, amely összefügg Deli Gergely egy további elhatárolásával, aki - Carl Schmittre utalással - megkülönbözteti egymástól a természetes és relatív alkotmányok korszakát, ${ }^{100}$ azzal a megállapítással, hogy a relatív alkotmány szükségszerüen a természetes alkotmányon nyugszik. ${ }^{101}$

E szerint a természetes alkotmányok korszakában az alkotmányos rend a természetes emberi együttélés magától, pontosabban a természettől adott rendje, az emberek együttélése pedig a túlélésért folytatott küzdelem természetes következménye: az

\footnotetext{
97 Vö.: Sulyok 2016b, pp. 339-358., Drinóczi 2018a, p. 2., illetve bővebben lásd jelen értekezés 2.5.3. fejezetét.

98 Takács 2007, p. 22.

${ }^{99}$ Deli 2018, p. 121.

${ }^{100}$ Lásd uo. 121 - 149.

101 A természetes és relatív alkotmányok, mint terminológia alkalmazása során felmerül a kérdés: ha beszélhetünk a relatív alkotmány kategóriájáról, úgy létezik-e az abszolút jellegű alkotmány? Amennyiben igen, akkor az abszolút jelleg minimum- vagy maximum tartalmat takar? Amennyiben a természetes alkotmány fogalma alatt az abszolút alkotmányt értjük, mint a társadalmi együttélés abszolút minimuma, megfontolandó lehet a természetes-relatív felosztás helyett az abszolút-relatív elhatárolás alkalmazása.
} 
emberek így létrejövő közösségének, az adottságokon alapuló hierarchikus rendje képezi a természetes alkotmányt, amely a leghatékonyabban képes elsődleges funkciójának, a közösség védelmezésének betöltésére. ${ }^{102}$ A természetes alkotmányon alapuló közösség természetszerüleg meghatározott az azt alkotó egyének tulajdonságai által, vagyis a közösség rendjét maguk az azt alkotó egyének határozzák meg, akik egyúttal alá is vetik magukat ennek a rendszernek. ${ }^{103}$

Másként megfogalmazva, a közösséget alkotó egyének identitása meghatározza a közösség identitását (tkp. kollektív identitásképzés) ${ }^{104}$, hogy a közösség védelmező funkciója a lehető leghatékonyabban valósulhasson meg, vagyis a közösség müködése a lehető legközelebb álljon az egyénhez annak érdekében, hogy az egyén a lehető legteljesebben alávethesse magát annak.

Mikor a fenti, a védelmező funkción alapuló rend intézményesül, átlépünk a relatív alkotmányok korszakába ${ }^{105}$, ahol az állam létezése és célja a fentiek szerint nem kérdéses, az állam struktúrája és sajátosságai azonban már igen. A relatív alkotmányok korszakában az állam már nem pusztán a közösség tagjainak védelmét kívánja ellátni, de a rendelkezésre álló (véges) javakat a társadalmi igazságosság szerint kívánja szétosztani. ${ }^{106}$ Mindezt azonban egy olyan rendben kell megtennie, amely a lehető legjobban megfelel az államot létrehozó és alkotó személyek, vagyis a közösség természetének. Ezzel pedig elérkezünk az alkotmányok egyfajta fokméröjéhez is: az alkotmány mennyire felel meg az életre hívó közösség természetének? Az alkotmányos közösség mennyire képes az alkotmányos rendet elfogadni? Gondoljunk például Koszovó esetére, ahol az alkotmányozás külső behatás eredménye, amelynek következménye, hogy az alkotmány elfogadása a közösség által legalább is kérdéses.

Az alkotmány alapvető célja tehát az állam müködésének garantálása az által, hogy fenntartható rendet teremt az állam és polgárai között, illetve az állampolgárok egymás közötti viszonyaiban, amely a posztmodern alkotmányok korszakában kiegészült az

\footnotetext{
102 Deli 2018, pp. 121-126.

${ }^{103}$ Deli 2018, pp. 125-129, 134-140.

${ }^{104}$ Vö.: Habermas 1994, pp. 154-168.

105 Deli 2018, p. 127.

${ }^{106}$ Lásd Deli 2018, pp. 124-125.
} 
emberi méltóság feltétlen biztosításával. ${ }^{107} \mathrm{Ez}$ a kérdés azonban már átvezet az alkotmányosság követelményeinek rendszeréhez, vagyis hogy milyen kritériumok betartásával kell az alkotmánynak megvalósítania természetszerű célját: milyen kritériumok szerint kell biztosítania az állami rendet. ${ }^{108}$

$\mathrm{Az}$ eddig tett megállapítások természetesen igazak lehetnek bármely alkotmányos rendszerre. Az európai integráció szupranacionális jellege azonban egy speciális állapotot hoz létre az alkotmányos rendszerek egységbe foglalásával, amelyre kvázi a hatásellenhatás törvénye szerint a tagállamok reakciója a folyamatos önmeghatározás iránti igény ${ }^{109}$, a történelmi sajátosságok és az alkotmányos berendezkedést meghatározó alkotmányban foglalt értékek védelme. Eltekintve az Európai Unió fejlődéstörténetének elemzésétől ${ }^{110}$, megállapítható, hogy az integrációs folyamat kvázi lételméleti kérdés a tagállamok szempontjából és a globalizáció szükségszerű következménye.

A globálissá váló nemzetközi és gazdasági környezetben bár nemzetállamokról beszélünk, mégis egyre inkább (az alkotmányjogász fülének talán kissé kellemetlenül ható) szuperhatalmakról kell beszélnünk: gazdasági szempontok szerint szervezett erőközpontokról. ${ }^{111}$ Analógiával és talán némi fantáziával azt mondhatjuk, hogy e globális környezet megítélése hasonló a természetes alkotmány állapotához az egyének szintjén: a túlélésért (az államok esetében érvényesülésért) folytatott versenyben az európai (nemzet)államoknak közösségbe kell tömörülniük, hogy biztosítsák önmaguk túlélését (érvényesülését). Vagyis az európai államok, ha a globális színtéren kívánnak érvényesülni, egységbe kell, hogy tömörüljenek, amihez - mint az emberi közösségeknek - meg kell határozniuk azt a rendet, ami alapján ezt a közösséget müködtetik. Ebben a kontextusban úgy tünik, hogy az európai integráció jelenleg a természetes alkotmányok időszakát éli, amely egyúttal magyarázat lehet az identitásviták mind hangsúlyosabb, erösödő jellegére is.

\footnotetext{
${ }^{107}$ Deli 2018, pp. 147-148.

108 Vö.: Takács 2007, pp. 29-31, Holmes 2012, pp. 189-217.

${ }^{109}$ Vö.: Rosenfeld 2010, p. 38.

${ }^{110}$ Vö.: Blutman 2013, pp. 31-40.

111 Tarrósy 2006, p. 180.
} 


\subsubsection{Az alkotmány jogi értelemben alkalmazott fogalma és az alkotmányos értékek}

Visszatérve a tételes jog talajára, az alkotmány - jogi értelemben vett fogalmát tekintve ${ }^{112}$ - minden olyan jogi norma összessége, ami az államilag szervezett társadalom alapvető rendjét konstituálja, ${ }^{113}$ vagyis amely, vagy amelyek az államhatalom megszervezésének, gyakorlásának és ellenőrzésének meghatározott elvek és követelmények ${ }^{114}$ szerinti szabályozásával hozza, vagy hozzák létre a tartós alaprendet. ${ }^{115}$ A jogi értelemben vett alkotmány mint alaptörvény (vagy alaptörvények ${ }^{116}$ ) tehát pozitivista felfogás szerint kifejezi a demokratikus államrend lényegét, meghatározza annak intézményi formáit, a jogállamiság követelményeit, az alapjogokat és azok garanciáit, a közhatalom céljait, eszközeit, szervezetét és korlátait. ${ }^{117} \mathrm{Az}$ alkotmány értékközpontú felfogása szerint azonban az alkotmány több alapvető normák összességénél: azoknak az elveknek és értékeknek ${ }^{118}$ a katalógusa, amelyekre az állam épül. ${ }^{119}$ Ezen értékalapú megközelítésben tehát az alkotmány egyúttal a nép önkifejezésének eszköze és kulturális örökségének tükre $^{120}$, amely azonban felveti az alkotmány értéksemlegességének problémáját: ${ }^{121}$ hordozhat-e az alkotmány az alkotmányozó által rögzített értékeket (presctiptive constitution), vagy értéksemlegesnek kell lennie (procedural constitution)? ${ }^{122}$ Megjegyzést érdemel, hogy az értéksemleges és az „értéktartalommal bíró” alkotmányok hermetikus elválasztása inkább elméleti kategóriának tekinthető, sokkal inkább a két végpont közötti skáláról van szó, amelyen az egyes alkotmányok értékhordozó jellegük szerint elhelyezhetők. A magyar viszonylatban a korábbi Alkotmány értéksemlegesnek tekinthető, míg az Alaptörvény kifejezett értékhordozó jelleggel bír. ${ }^{123}$ Jelen értekezésnek nem célja állást foglalni egy alkotmány értéksemlegességének (vélt?) szükségességéről,

\footnotetext{
112 Bulmer 2014, p. 2.

${ }^{113}$ Petrétei 2011, p. 48.

114 Vö.: Takács 2007, pp. 29-31., Smuk 2014, pp. 22-27., Petrétei 2011, pp. 99-115., Dorsen-RosenfeldSajó-Baer 2003, pp. 10-12.

115 Zeller 2005, pp. 42.

${ }^{116}$ Az alkotmány megjelenési formája eltérő lehet a szerint, hogy az alkotmányos rendszer a történeti, vagy a kartális alkotmány konstrukciót alkalmazza. Az egyes alkotmányfejlődési irányokat bővebben lásd pl. Takács 2007, pp. 23-28.

117 Takács 2007, pp. 28-29.

${ }^{118}$ Az alkotmányi értékekről bővebben lásd: Ádám 2010, pp. 115-127.

${ }^{119}$ Csink 2015, p. 135.

120 Takács 2007, p. 28.

$121 \mathrm{Az}$ alkotmányban rögzített értékek lehetséges megközelítéseiről lásd pl.: Majtényi 2017, Trócsányi 2015, pp. 321-323.

122 Bulmer 2014, pp. 6-7.

${ }^{123}$ Vö.: Trócsányi-Schanda 2016, pp. 56-61.
} 
azonban a már alkotmányban rögzitett értékek szorosan kapcsolódnak az alkotmányos identitás kérdéséhez, hiszen az alkotmányban rögzített értékek formálhatják az azt életre hívó társadalmat és vice versa: az alkotmányban csak olyan értékeket rögzíthetünk, amelyeket az alkotmányos közösség képes befogadni.

Az alkotmányban foglalt értékekkel kapcsolatban két alapvető kérdést kell feltennünk: mit tekintünk értéknek és ezek kinek az értékei? ${ }^{124}$ E felmerülő kérdések - vagy sokkal inkább az adott / adható válaszok - azonban alapvetően változnak meg, ha azokat nem az alkotmányos rendszeren „,belülről” szemléljük. Az alkotmány és az azt életre hívó társadalom kölcsönös, egymást formáló relációját, illetve az alkotmány társadalomra gyakorolt értékformáló hatását (funkcióját?) Habermas alkotmányos patriotizmus elméletében vizsgálja. ${ }^{125}$

Ahogyan azt Majtényi tárgyalja, „házon belül” a kérdés az, hogy helyes-e, ha az alkotmány az alkotmányozó által meghatározott, a közösség egyes rétegei által vallott meghatározó elveket, morális, történelmi, vallási, stb. megfontolásokat az alkotmány szintjén, alkotmányosan védendő értékeknek nyilvánít, illetve ebben az esetben létezik-e homogén közösség, aki magáénak vallja ezeket az értékeket, vagy létrejön az „alkotmányos kisebbség” akik azonban nem vallják maguknak azokat. ${ }^{126}$

Ha a problémát egy külső perspektívából az európai integráció szintjén kezdjük vizsgálni, a kérdés nem az lesz, hogy vannak-e, lehetnek-e az alkotmány szintjén az alkotmányozó által rögzített értékek, hanem hogy melyek ezek. Mik azok a társadalmi, kulturális, politikai, intézménytörténeti, stb. attribútumok, amelyek (adott esetben kénytelenkelletlen) meghatározzák az állam alkotmányos és politikai berendezkedését, amely tagállamként már nem a „légüres térben”, hanem egy közösség részeként létezik? Ebben a perspektívában felmerül az Európai Unió értékközösség jellegének kérdése, illetve az európai alkotmányos örökség gondolata, mint a tagállamokat összekötő egységes értékrend. ${ }^{127}$

\footnotetext{
${ }^{124}$ Majtényi 2017, pp. 5-11., Trócsányi 2015, pp. 322-323., Petrétei pp.147-157. A Magyar Alaptörvényben hordozott értékekkel kapcsolatban lásd pl. Smuk 2013, pp. 446-463.

${ }^{125} \mathrm{Az}$ alkotmányos identitás és az alkotmányos patriotizmus közötti kapcsolattal az értekezés 2.5.1 fejezete foglalkozik.

${ }^{126}$ Vö.: Majtényi pp. 6-7., illetve Pap 2014

${ }^{127}$ Bővebben lásd: Láncos 2013, pp.153-170.
} 
A korlátozott mértékben egységes értékrenden kívül (az „európai értékek” köre a Szerződésekben) azonban az egyes tagállamok rendelkeznek saját értékekkel is: olyan, a történelmi sajátosságokból fakadó egyéni attribútumokkal, amelyek meghatározzák az adott tagállami alkotmányos berendezkedést és amelyek nem feltétlenül elismertek más tagállamokban, vagy ami talán jelentősebb: eltérő tartalommal, eltérő súllyal elismertek.

Gondoljunk például az emberi méltóság védelmére: vitán felül álló, hogy az emberi méltóság védelme meghatározza az egész európai alkotmányos teret mind integrációs, mind az egyes tagállamok szintjén is. Németország azonban az emberi méltóság védelmét örökkévalósági klauzulába foglalta és azt az alkotmányos rendszer megváltoztathatatlan, legalapvetőbb attribútumának nyilvánította. Ez a kiemelt védelem nem feltétlenül jelenti azt, hogy jelenleg Németországban az emberi méltóság védelme erősebb, vagy eltérő védelemben részesülne a többi európai tagállamhoz képest. Azonban a történelmi perspektíva egyfajta ünnepélyes, „identitásformáló” deklarációt eredményezett, amely elvi jelentőséggel bíró sarokkövét jelenti az alkotmányos rendszernek. Így a védendő érték ugyanaz, mint bárhol az integrációban, a társadalmi érzékenység és a történelmi perspektíva azonban eltérő jellegüvé teszi annak megítélését. ${ }^{128}$ Hasonló jelenséggel találkozhatunk Franciaország és a laicitás kapcsán ${ }^{129}$, de a sort hosszan lehetne folytatni. Ténylegesen nehéz volna megállapítani és teljeskörüen összegyüjteni, hogy az egyes európai tagállamok alkotmányos hagyományaikból fakadóan miket tekintenek alkotmányos értékeknek, hiszen az eltérő történelmi perspektívából fakadóan ugyanazok a fogalmak tagállamonként is eltérő (és adott esetben időben változó) tartalommal bírhatnak. ${ }^{130}$

Ezeknek a tagállamonként eltérő attribútumoknak a védelme iránti igény az a központi jelenség, amelyre az alkotmányos identitás koncepciójának ${ }^{131}$ feltértékelődése visszavezethető. Ahogyan Drinóczi megfogalmazza, az alkotmányos identitás elsősorban a nemzeti alkotmányok rendelkezéseiböl olvasható ki, amely rendelkezések ugyanakkor az alkotmányos rendszer (berendezkedés) sajátosságait hordozzák egy globalizálódó

\footnotetext{
${ }^{128}$ Vö.: Müller 2016, pp. 73-79.

${ }^{129}$ Vö.: Levade 2016, pp. 71-72.

${ }^{130}$ Vö.: Trócsányi 2014c, pp. 9-16.

${ }^{131}$ Drinóczi 2018a, pp. 4-5.
} 
környezetben. ${ }^{132}$ Az alkotmányos identitás európai jelentőségét tehát a szupranacionális értékközösség teremti meg, amelyben az egyes alkotmányos rendszereknek nevesíteniük kell saját egyediségüket, amelyet azonban már az alkotmány értékhordozó természete tesz lehetővé.

Az alkotmányos identitás körül tárgyalandó minden további kérdés - többek között annak jogi relevanciája - e két tényező köré épül. Az alkotmányos identitás felértékelődésének jelenségét a szupranacionális környezet - amelynek velejárója az integráció értékközösséggé fejlődése - szükségszerüen és elkerülhetetlenül hívta és hívja életre. Ez egyúttal azt is eredményezi, hogy a nemzeti alkotmányok szerepe ennek megfelelően kiegészülni látszik az integráción belül a tagállami alkotmányos rendszerek védendő és speciálisan az adott tagállamra jelelemző, organikus alkotmányfejlődés során formálódó ${ }^{133}$ alkotmányos (és politikai) berendezkedés intézményeinek, értékeinek védelmével.

132 Uo.

${ }^{133}$ Uo. 


\subsubsection{Az alkotmány funkciói}

Az alkotmány fogalmához és az alkotmányok tipizálásához ${ }^{134}$ hasonlóan az alkotmány funkciói esetén is különböző felosztások, eltérő rendszerek léteznek, ${ }^{135}$ amelyek leginkább az egyes kategóriák distinkciós érzékenysége szerint változnak. ${ }^{136} \mathrm{Az}$ alkotmány tartalma és ezáltal az alkotmányok funkciói egyes alkotmányfejlődési irányok szerint ${ }^{137}$ és korszakonként is változnak, ${ }^{138}$ hiszen az alkotmányokat meghatározza az alkotmányos berendezkedés korábbi alkotmányfejlődése, amely az által determinált, hogy az adott állam mikor és hogyan lépett a polgárosodás útjára, milyen fejlődéseken és válságokon ment keresztül. ${ }^{139} \mathrm{Az}$ egyes alkotmányos rendszerek egyedi történelmi perspektíváján túl azonban az európai alkotmányos berendezkedésekre hasonló, vagy adott esetben ugyanazok a történelmi események hatottak. ${ }^{140}$ Példaként hozható a szociális alkotmányok létrejötte, illetve a Bonni Alaptörvény, amelynek elfogadásával a II. világháború tanulságai révén általánossá válik az alapvető jogok és az alkotmányosság követelményeinek megfelelő szintű és tényleges biztosítása, kezdetét veszi a mára európai standardokként aposztrofált alapjogvédelmi rendszer kialakulása, amely a nemzetközi egyezményeken túl elsősorban a nemzeti alkotmányokban öltött testet. ${ }^{141} \mathrm{Az}$ alkotmány funkciói tehát meghatározottak a nemzetközi környezet és közeg által is, amelyben az alkotmányos rendszer és így maga az alkotmány létezik. Az alkotmányi értékek és az alkotmányos identitás felértékelődésével és az egyes alkotmányos rendszerek önmeghatározásának szükségességével feltételezhetően szintén egy funkcionális átalakulás veszi (vette?) kezdetét ${ }^{142}$ - ha nem is a II. világháborút követő időszakhoz hasonló intenzitással és mértékben -, amelynek főszereplői a tagállami alkotmány- és felsőbb bíróságok. ${ }^{143}$

\footnotetext{
${ }^{134}$ Vö.: Grimm 2012, pp. 98-133.

135 Jakab András az alkotmány két funkcióját különbözteti meg: a politikai hatalom korlátozását, illetve a szimbolikus funkciót. A felosztás ismertetését bővebben lásd: Balázs 2015, pp. 87-88.

${ }^{136}$ Az alkotmány lehetséges funkcióit lásd például: Bulmer 2014, pp. 3-4.

137 Vö.: Takács 2007, pp. 23-29.

138 Vö.: Trócsányi - Schanda 2016, pp. 37-46.

${ }^{139}$ Uo. p. 37.

140 Trócsányi 2014d, pp. 41-42.

${ }^{141}$ Vö.: Sári-Somody 2008, pp.19-28.

${ }^{142}$ A jelenséget érdemes lehet megvizsgálni az alkotmányos konvergencia elméletének szemszögéből is: E szerint az alkotmányokra a globalizálódó (társadalmi) folyamatok révén univerzálisnak tekinthető tendenciák, „mélyebb erők” hatnak melyek konvergálódása képződik le az egyes alkotmányok szabályozásában. Vö.: Sulyok 2017, pp. 144-151.

${ }^{143}$ Vö.: Sulyok 2014, pp. 50-51.
} 
A jogi értelemben vett alkotmány funkcióinak meghatározásakor Petrétei József öt kategóriát különböztet meg, amely felosztást a továbbiakban irányadónak tekintek. E szerint elkülöníthető az államhatalmat konstituáló, racionalizáló és korlátozó funkció (i), a stabilizáló és rendezettséget biztosító (ii), a legitimáló (iii), a polgárok alapvető jogait és ezek védelmét biztosító (iv), illetve az alkotmány konszenzusképző, egységteremtő funkciója (v). ${ }^{144}$

Az alkotmány eszerint mint legalapvetőbb jogforrás, tartalmazza az államhatalom eredetére és a hatalom gyakorlásának rendszerére vonatkozó legfontosabb elöírásokat, egyúttal ezzel keretet is szabva a hatalom gyakorlásának (i), amely rendszernek azonban egyúttal úgy kell e normatömeget kialakítania, hogy biztosítania kell a fenntartható és egységes társadalmi szerkezetet (ii). Az alkotmány, mint a nép általi felhatalmazáson alapuló alkotmányozó (népszuverenitás elve) akaratának megtestesülése egyúttal az államhatalom forrása is, ezért az állami hatalom minden aktusának - a demokratikus legitimáció elvének megfelelően - visszavezethetőnek kell lennie az alkotmány rendelkezéseire (iii). A hatalom gyakorlása azonban az alkotmányosság követelményeinek megfelelően nem lehet korlátlan: az alkotmány a polgárok alapvető szabadságjogainak garantálásával megszabja az államhatalom beavatkozásának határait, tiszteletben tartva a polgárok önrendelkezési jogát és privát autonómiáját (iv).

Végül az alkotmánynak, hogy előbbi funkcióit betölthesse, elöször kifejezésre kell juttatnia egy minimális társadalmi konszenzust, alapvető társadalmi megegyezést, amelynek eszközeiként tekinthetők az egyes alapvető értékek, eszmék, államcélok, alkotmányos elvek, stb. Ahogyan Petrétei megfogalmazza, „ez a minimális konszenzus biztositja azt a keretrendet, ami lehetővé teszi a társadalmi együttélésböl szükségszerüen adódó, különbözö - sokszor ellentétes - érdekek és törekvések ütközéséböl származó legjelentösebb társadalmi konfliktusokjogi elöírások formájában való kanalizálását." 145 (v)

Az alkotmány funkcióinak fenti felosztása - ahogyan a legtöbb felosztási rendszer azonban az államon belüli társadalmi, politikai és jogi viszonyrendszerek vonatkozásában vizsgálja az alkotmány szerepét. A szupranacionális jogrendhez csatlakozással

\footnotetext{
${ }^{144}$ Petrétei 2011, pp. 64-67.
}

145 Petrétei 2011, pp. 65. 
ugyanakkor a tagállami alkotmányok már közvetítő szerepet is betöltenek: az uniós, az államon kívüli, bizonyos szempontból az állam feletti jogrend és a nemzeti jog összhangjának biztosításával az alkotmány egyfajta hidat képez az uniós és a nemzeti jog között, egyúttal a szuverenitástranszfer révén megteremti a tagállamkénti létezés feltételeit. ${ }^{146}$

Egy olyan jogrendhez csatlakozás révén azonban, amelynek egyes normái feltétlen érvényesülést követelnek, adott esetben még magával az alkotmánnyal szemben is, ${ }^{147}$ az alkotmányos rendszer nyitottá válik a közösségi szabályozás felé, egyúttal - az alapító szerzödések által megkövetelt, ugyanakkor a nemzeti alkotmány által lehetővé tett mértékben - alá is rendelődik annak, vagyis a közösségi jogrend az alkotmány felhatalmazására visszavezethetően változást eszközölhet abban a társadalmi rendben, amelyet korábban nevesített funkció szerint az alkotmány létrehoz és szabályoz. Amennyiben az uniós jog alkalmazása az alkotmányos rendszer egyes alapvetőnek tekintett értékeit, struktúráját, vagy intézményeit érintő változást eredményezne (amelyek az alkotmány által meghatározottak) úgy az - ismét a hatás-ellenhatás törvényének megfelelően - kiváltja, illetve kiválthatja az alkotmányos rendszer (berendezkedés) önazonosságának védelmére irányuló reakcióját, amely így átvezet az alkotmányos identitás problémaköréhez.

Mindezek figyelembevételével álláspontom szerint az alkotmány funkcióinak korábban ismertetett katalógusa az uniós jogrendhez csatlakozás révén - és az integráció mélyülésével - kiegészülni látszik egyfajta integrációs funkcióval, amelynek éppúgy része az uniós jog és a nemzeti jog kapcsolatának meghatározása, mint az alkotmányos rendszert meghatározó alapvető értékek, alkotmányos elvek, illetve intézmények és így a tagállam alkotmányos identitásának védelme.

146 Vö.: Vincze-Chronowski 2018, pp. 31-94.

${ }^{147}$ Blutman-Chronowski 2007, p. 3. 


\subsection{Az alkotmányos identitás fogalma}

Jacobsohn az alkotmányos identitás elemeiben az alkotmányos rendszer olyan meghatározó jellemzőit látja, ${ }^{148}$ amelyek nélkül az valami egészen mássá alakulna át. ${ }^{149}$ Alkotmányos diszharmónia elmélete szerint ${ }^{150}$ az alkotmányos identitást a társadalmi legitimációval felruházott alkotmányozó hatalom által megalkotott alkotmány és az azt meghatározó társadalmi, politikai erők közötti konfliktus által generált feszültség „,végső” kimenetele határozza meg. ${ }^{151}$ Rendszerében elválasztja az alkotmányt, az azt létrehozó alkotmányozó hatalmat és szembe állítja a hatalommal felruházó társadalommal, azaz az alkotmányos közösséggel. Álláspontja szerint az így létrejövő folyamatos konfliktusok, illetve kölcsönhatások „eredménye” formálja az adott rendszer alkotmányos identitását. ${ }^{152}$

Következésképpen a jelenséget a kontinuitás szemüvegén át kell vizsgálni: a fent nevesített faktorok „egymásra hatása” folyamatként jelentkezik, amelynek eredményeként a folyamat „kivetüléseként” jönnek létre az alkotmányos identitás egyes jegyei. Ez egyúttal azt is jelenti, hogy az alkotmányos identitás elemei nem értelmezhetőek elkülönítve, „önmagukban”, kizárólag az őket létrehozó közeg, az alkotmányos alany múltjának, jelenének és jövőjének figyelembevételével. ${ }^{153}$ Sulyok az alkotmányos identitással összefüggésben annak statikus és dinamikus értelmezését hasonlítja össze, ${ }^{154}$ amely értelmezésben a dinamikus szemléletmód irányul az alkotmányosság integrációs folyamataiban rejlö identitás-elemekre, illetve irányulhat természetesen - egy ,integráció-semleges” kontextusban az adott ország alkotmányos kultúrájának, közjogi hagyományainak feltérképezésére is. ${ }^{155}$

\footnotetext{
${ }^{148}$ Az alkotmányos identitás vizsgálatát az egyes alkotmányos modellek szerint részletesen lásd: Rosenfeld 2010, pp. 149-209.

149 Jacobsohn 2013, p. 1.

150 A Jacobsohn által kimunkált elmélet rendkívül gyakorlatias módon, az egyes példákból felvezetett alkotmányos jelenségek bemutatása révén mutatja be az alkotmányos identitás fogalmát, vizsgálódási módszertana azonban tagadhatatlanul tükrözi az angolszász jogi gondolkodást, kiindulópontként pedig az Egyesült Államok és India alkotmányos ,,pillanatait”, identitásjegyeit alkalmazza.

${ }^{151}$ Az alkotmányos diszharmónia elméletet bővebben lásd: Jacobsohn 2010.

152 Jacobsohn 2013, p. 1.

153 Vö.: Martonyi 2018, p. 21.

${ }^{154}$ Vö.: Sulyok 2014, pp. 44-46.

155 A jelenség párhuzamba állítható történeti alkotmányunk vívmányaival, mint az Alaptörvény egyik értelmezési tartománya, mellyel ,az Alaptörvény mintegy ablakot nyit közjogunk történeti dimenziójára." Vö.: 33/2012 (VII. 17.) ABH
} 
Rosenfeld szerint „még ha az alkotmányos alany „,ki” és „,mit” kérdései rendezve is lennének, az alkotmányos identitás fogalma még mindig nehézségekkel telve lenne. Nem csak arról beszélünk, hogy az alkotmányos identitás minden valószínüség szerint idővel változni fog, hanem arról is, hogy mélyen elmerülne az egyéb meghatározó identitásokkal folytatott összetett és ellentmondásos kapcsolatokban, úgy mint: nemzeti, etnikai, vallási, vagy kulturális identitás. [...] Hogy létrehozzuk az időkön átívelö identitást, elengedhetetlen, hogy egybe szőjük az alkotók múltját, a saját jelenünket és a meg nem született generációk jövőjét. A probléma az, hogy a múlt ugyanannyira bizonytalan, mint a jelen és így utat engednek ellentmondásos lehetöségeknek." 156

Egyetértek a rosenfeldi állásponttal abban, hogy az alkotmányos identitás egzakt meghatározása problematikus és a jelenség nehezen körülhatárolható. Ugyanakkor nem értek egyet abban, hogy az alkotmányos alany meghatározása többértelmüséget eredményezne. Jacobsohn rendszerében az alkotmányos identitás magában foglalja a Rosenfeld által felsorolt elemek [alkotmányos közösség, alkotmányozó hatalom letéteményesei és az alkotmány] mindegyikét, együttesen alkotják az alkotmányos identitást hordozó entitást, vagyis az alkotmányos alanyt, ezért Jacobsohn gondolatai kiegészítik a rosenfeldi rendszert és az abban felmerülő aggályokat gyakorlatilag Jacobsohn megválaszolja. ${ }^{157}$

Egyúttal Jacobsohn az alkotmányos identitásra - többek között -, mint ,,számos, a nemzet múltját kifejezö törekvés és vélemény elegyeként megjelenö, a bíróságokon, a törvényhozásban folyamatosan alakuló jelenségre”, illetve a köz-, és magánszféra színterein folyamatosan zajló politikai és értelmezési viták összességére utal. ${ }^{158}$ Szemléletében az alkotmányos identitás jelensége nem értelmezhető egy idősíkon, azaz a jelenben megjelenő, az adott alkotmányos rendszert jellemző tényezők (statikus) összességében.

A korábban már részben tárgyaltak szerint az alkotmányos identitás fogalma más-más megközelítésben jelenik meg az angolszász jogrendszerekben (és jogirodalmi

\footnotetext{
${ }^{156}$ Rosenfeld 1995, p. 1049.

157 Vö.: Jacobsohn 2010, pp.1-35, Rosenfeld 2010, pp. 37-65.

158 Jacobsohn 2013, p. 5.
} 
felfogásban), ${ }^{159}$ illetve az európai integráció szupranacionális rendszerében. ${ }^{160} \mathrm{Az}$ angolszász jogirodalomban az identitáselméletek kutatói az alkotmányt életre hívó alkotmányos közösség, az alkotmányozó hatalom és az alkotmány konfrontatív viszonyának dinamikus kölcsönhatását látják az alkotmányos identitásban. ${ }^{161}$ Eszerint a társadalom (ti. alkotmányos közösség) identitása meghatározza az alkotmányt és vice versa, az alkotmány hatást gyakorol a társadalmi identitásra. ${ }^{162}$ (Eredeti megközelítésében az alkotmányos identitást a korábban már szintén érintett és a későbbiek során tárgyalt, Habermas nevéhez köthető alkotmányos patriotizmus [Verfassungspatriotismus] elméletével ${ }^{163}$ szokás összehasonlítani, ${ }^{164}$ amely szerint az alkotmányos normák iránti elköteleződésnek kell meghatároznia a közösségeket. ${ }^{165}$ )

Míg tehát angolszász megközelítésben az alkotmányos rendszer és így az alkotmány organikus fejlődésének keretei jelentik az alkotmányos identitás alkalmazásának koordináta rendszerét - különös tekintettel az alkotmányellenes alkotmánymódosítás kérdéskörére - ${ }^{166}$ addig az európai felfogás középpontjában az európai szupranacionális jogrend és a tagállami alkotmányok viszonya, a tagállamok alkotmányos berendezkedését meghatározó alapvető jogelvek, értékek és intézmények, illetve az integrációs jog esetleges kollíziója áll. ${ }^{167}$ Az alkotmányos identitás meghatározásakor értekezésemben osztom azon uralkodónak tekinthető álláspontot, amely szerint az alkotmányos identitás koncepciójának kontinentális értelmezése, illetve ezzel összefüggésben az EUSZ 4. cikk (2) bekezdésének alkalmazása végső soron a tagállami alkotmányértelmezők, illetve az Európai Unió Bíróságának joggyakorlatában kell, hogy testet öltsön. ${ }^{168}$ Az európai perspektíva megértéséhez ugyanakkor egy rövid kitekintés erejéig érdemes kilépni az alkotmány- és jogértelmezés kötött dimenziójából és az európai integrációt a kollektív identitásképzés szociológiai folyamatának szemüvegén át szemlélni.

\footnotetext{
159 Vö.: Jacobsohn 2010, Polzin 2017, pp. 1599-1604.

${ }^{160}$ Arnaiz-Llivina 2013, pp. 3-12, 93-109., Rychetsky 2017, p. 95, Bogdandy-Schill 2011, pp. 1417-1722.

${ }^{161}$ Jacobsohn 2010, pp. 1-35, Jacobsohn 2013, p. 5.

162 Polzin 2017, pp. 1599-1606.

163 Jacobsohn 2010, pp. 2-6.

${ }^{164}$ Polzin 2017, pp. 1600-1601.

165 Vö.: Müller 2008

166 Vö.: Jacobsohn 2010, pp. 34-84.

${ }^{167}$ Polzin 2017, p. 1597, Rychetsky 2017, Trócsányi 2014a, pp. 22-77., Német Alkotmánybíróság Solange II. Döntése (Wünsche Handelsgesellschaft decision of 22 October 1986, BVerfGE 73, 339, case number: 2 BvR 197/83), stb.

${ }^{168}$ Sulyok 2014, pp. 50-51. Az EUSZ 4. cikk (2) bekezdés értelmezési kérdéseit részletesen jelen értekezés 4.1. fejezete tárgyalja.
} 
Az identitás, illetve identitásképzés folyamatánál levezetettek szerint Bodó Barna - Erik H. Erikson tételeiből kiindulva - az identitásban az önmagáról gondolkodó entitás azon kísérletét látja, amelyben az megkísérli nevesíteni azon faktorokat, amellyel eltér, vagy éppen megegyezik más entitásokkal. ${ }^{169}$ Habermas szerint a kollektív identitások esetén az azokat alkotó én-struktúrák univerzalizálódásának, illetve a kollektív identitás dominánsabbá válásának jelensége figyelhető meg, ${ }^{170}$ vagyis a kollektív identitás, amely az azt létrehozó entitások (legyenek azok egyének, közösségek, vagy az európai integráció esetében a tagállamok) egységes akaratából jön létre, visszahat a létrehozó entitások identitására, szükségszerűen formálja is azokat. E megközelítésből szemlélve az integrációt, az Európai Unió, mint a kollektív identitás hordozója szükségszerüen meghatározza, illetve formálja az azt életre hívó tagállamok identitását. A folyamat a tagállami alkotmányos rendszerekből kétféle természetes reakciót válthat ki: bizonyos fokú szükségszerü alárendelődést, amely a kollektív identitás részeként létezés következménye; és egyúttal ellenállást is, amely az egyedi, a kollektív identitást életre hívó entitás (ti. tagállamok) természetes válaszreakciója, amellyel az én-struktúrát (ti. alkotmányos berendezkedést) védelmezik. ${ }^{171}$

Szupranacionális perspektívából megközelítve a kérdést, az identitásképzés egy második szintjével kerülünk szembe. Itt a kollektív (integrációs) és az egyéni (alkotmányos) identitás konfrontatív viszonya az alkotmányjog koordináta-rendszerében értelmezve egy komplex problémakört hoz létre, amelynek részét képezi a szuverenitás kérdése (mint végső, legfőbb döntési jogosultság), ${ }^{172}$ a tagállami alkotmányok és az uniós jog összhangja, illetve a tagállami alkotmánybíróságok és az EUB kvázi hatásköri összeütközése. ${ }^{173}$ Ugyanúgy ehhez a problémakörhöz sorolható még az alkotmányokban rögzített alkotmányos értékek védelme (amelyeket jellemzően az alkotmányozó hatalom deklarál az alkotmányozás folyamatában) is. ${ }^{174}$ Az EUSZ 4. cikk (2) bekezdés értelmezési kérdései, ${ }^{175}$ és ez utóbbival szoros összefüggésben a tagállamok alkotmányértelmezőinek

\footnotetext{
169 Bodó 2004, p. 13.

170 Vö.: Habermas 1994, pp. 154-168.

171 Vö.: Rosenfeld 2010, p. 38.

172 Idézi Körösényi András, Schmittre és Böckenfördére utalással: Körösényi 2004, p. 158.

${ }^{173} \mathrm{Az}$ uniós jog autentikus értelmezőjeként az EUSZ 4. cikkének értelmezése az EUB kompetenciája, míg a tagállami alkotmányok erga omnes hatályú autentikus értelmezői a tagállami alkotmány és legfelsőbb bíróságok. Vö.: Szakály 2015, p. 35.

${ }^{174}$ Vö.: Petrétei 2011, pp. 147-157., Majtényi 2017, pp. 3-10., Chronowski 2015, pp. 19-31., 19-20.

${ }^{175}$ Vö.: Arnaiz - Llivina 2013, pp. 8-12, Bogdandy -Schill 2011, pp. 1420-1429.
} 
kompetenciája az alkotmányos identitás kérdését illetően is ide tartoznak természetesen. ${ }^{176}$

Az angolszász (döntően amerikai) jogtudomány az identitáselméletekből fakadó törvényszerüségek megfogalmazására épít és az alkotmányos identitásra mint az alkotmányelmélet kiindulópontjára, az alkotmányos rendszerek természetéből fakadó törvényszerüségek rendszerére tekint. ${ }^{177} \mathrm{Az}$ identitáselméletek középpontjában az alkotmányt életre hívó társadalom és az alkotmány kapcsolata áll, illetve az e kapcsolatból fakadó, az alkotmányt meghatározó követelmények. ${ }^{178}$ Ezzel szemben az európai megközelítés sokkal inkább gyakorlati igénnyel közelít az alkotmányos identitáshoz, különös tekintettel a tagállami alkotmánybíróságok gyakorlatára. ${ }^{179} \mathrm{Az}$ integráció tagállamainak alkotmányértelmező testületei az uniós jogban való megjelenése óta az integráció és a tagállamok alkotmányos szabályainak összeütközése esetére kvázi rendező elvként próbálják alkalmazni az alkotmányos identitás koncepcióját, ${ }^{180}$ hiszen az Európai Unió többszintü alkotmányosságának rendszerében régóta vitatott terület a közösségi szabályozás és a tagállamok alkotmányos szabályainak összeütközése. ${ }^{181}$

Az alkotmányos identitás uniós jogrendben betöltött szerepe a felmerülő kérdéseket, illetve problémákat azonban csak részben válaszolja meg: az EUSZ 4. cikk (2) bekezdés első fordulata által rögzített identitás-klauzula, illetve a második fordulat által rögzített alapvető állami funkciók tiszteletben tartásának követelménye elválasztja egymástól a szupranacionális és tagállami alkotmányos jogrendek összeütközésének egyes területeit, amelyek ezáltal az alkotmányos identitás és a szuverenitás kérdéskörére oszthatók fel. A szupranacionális jogrendből fakadó anomáliát, az alkotmányos paradoxont, illetve az EUSZ hivatkozott rendelkezéseit a későbbiekben részletesen is vizsgálom.

$\mathrm{Az}$ alkotmányos identitás koncepciója ${ }^{182}$ és felfogása, ${ }^{183}$ illetve értelmezési szempontrendszere ${ }^{184}$ - amely változik, vagy sokkal inkább organikusan fejlődik ma is és

\footnotetext{
176 Vö.: Sulyok 2014, pp. 50-51., Rychetsky 2017

177 Jacobsohn 2010, p. 3.

${ }^{178}$ Minimum standardok? Vö.: Drinóczi 2016a, pp. 213-233, pp. 112-223.

${ }^{179}$ Vö.: Rychetsky 2017

${ }^{180}$ Arnaiz -Llivina 2013, p. 3., Orbán 2018, pp. 1-2.

${ }^{181}$ Vö.: Blutman 2017, pp. 1-14., Blutman - Chronowski 2007, pp. 3-16.

182 Pl.: Chronowski - Vincze 2017, pp. 93-127.

${ }^{183}$ Blutman 2017, pp. 8-9., Drinóczi 2016b, pp. 39-42.

${ }^{184}$ Pl.: Polzin 2017, pp. 1604-1615., Sulyok 2014
} 
vélhetően fog a jövőben is - sok esetben eltérő tartalommal jelenik meg a jogtudomány képviselői, a tagállami alkotmányértelmezők, az integráció oldaláról az EUB, illetve a magyar példát tekintve tagállami oldalról az alkotmánymódosító hatalom számára is.

Míg a jogtudományban az alkotmányos identitás tudományos viták kereszttüzében álló olyan fogalom, melynek egzakt meghatározására a jogtudomány kísérletet tesz, addig az alkotmányértelmező testületek - olykor a jogtudomány álláspontjának alkalmazásával válaszokat adnak és tartalommal töltik meg a koncepciót szerte az integrációban. Egy újfajta és szokatlan szegmense azonban az identitásról folyó diskurzusnak és gyakorlatnak az alkotmányozó hatalom részvétele a folyamatban. A Magyar Alaptörvény hetedik módosítása önmagában is hosszas vitának adott alapot a múltban és fog a jövőben is, ezért e helyütt csak utalok arra, hogy az alkotmányos identitás védelmének alkotmányi szintü rögzítése nem feltétlenül szerencsés a fogalom - jelenleg - valamelyest meghatározatlan tartalma és tagállamonként eltérö értelmezése miatt.

Az alkotmányos identitás (jog)elméleti alapjainak meghatározása, illetve megértése a fentiekre tekintettel kiemelt jelentőségű a koncepció alkalmazhatósága szempontjából: egy jogelméleti alapokon nyugvó modell alkalmazásával hosszú távon közelíthetők az eltérő értelmezési sémák, illetve terminológiák. Annál is inkább, mivel megfigyelhető tendencia, hogy az európai integráció erősen átpolitizált jellege magában hordozza az (alkotmányos) identitás koncepció - amely alkotmányelméleti kategória - politikai jellegű feloldódásának veszélyét. ${ }^{185}$

Visszatérve Jacobsohn alkotmányos diszharmónia-elméletéhez, szerinte ${ }^{186}$ az alkotmányos identitást az alkotmányos rendszerben azonosítható három faktor egymásra hatása hozza létre. ${ }^{187}$ Ezek az alkotmányt életre hívó alkotmányos közösség, az alkotmányozó hatalom és az alkotmány. ${ }^{188}$ Álláspontja szerint e három szereplő konfrontatív viszonya teszi többé az alkotmányt puszta dokumentumnál - teszi élővé -

\footnotetext{
185 Ahogyan arra Trócsányi is utal, a nemzeti identitás inkább politikai, mintsem jogi tartalmú fogalom. Vö.: Trócsányi 2014a, p. 72.

186 Vö.: Tommasso Pavone: Constitutional Identity: An Overview and Some Conceptual Concerns https://scholar.princeton.edu/sites/default/files/tpavone/files/jacobsohn-

_constitutional_identity_critical_review.pdf

187 Jacobsohn 2013, p. 5.

188 Vö.: Tribl 2018, pp. 151-164, 158.
} 
és e konfrontatív viszony szegletkövei jelentik az alkotmányos rendszer egyes identitásjegyeit. ${ }^{189}$

Rosenfeld plurális alkotmányosság teóriája ${ }^{190}$ kvázi Jacobsohn diszharmónia elméletének kiegészítéseként értelmezhető: az alkotmányos rendszer Rosenfeld értelmezésében az alkotmányos alanyként jelenik meg, amely a három faktor - alkotmányos közösség, alkotmányozó hatalom, alkotmány - konfrontatív egymásra hatása révén egyedi jellemzőket, kvázi „viselkedési mintát” alakít ki és határozza meg önmagát. ${ }^{191}$

Jacobsohn az alkotmányos identitás egyik legrelevánsabb területeként az alkotmányellenes alkotmánymódosítás jelenségét emeli ki, középpontban a kérdéssel: milyen mértékben módosítható az alkotmány? Az alkotmányos identitást az alkotmány organikus fejlődésének folyamatában helyezi el és azt vizsgálja, hogy milyen mértékben változtatható meg az alkotmány anélkül, hogy a változtatás az alkotmányos berendezkedés (alkotmányos alany) identitását sértené. Vagyis hol húzódik az a határ, mikor a módosítások révén az alkotmány már nem illeszkedik az azt életre hívó alkotmányos rendszerbe és ennek következtében, a módosítások révén, az alkotmányos berendezkedés destabilizálódna, ${ }^{192}$ elveszítené önazonosságát. ${ }^{193}$ (Jacobsohn elméletében nem az alkotmány változtathatatlanságáról van tehát szó, hanem arról a határmezsgyéről, amelyen túl a változtatás már nem illeszkedik azt alkotmányt életre hívó rendszerbe.)

Mindezek alapján az alkotmányos identitás:

(i) az alkotmányos rendszer organikus fejlődésének folyamatát írja le, amelynek egyes meghatározó elemei az alkotmányos közösség, az alkotmányozó hatalom és az alkotmány, amely három tényező kölcsönhatásaként jön létre az alkotmányos (rendszer) berendezkedés.

\footnotetext{
${ }^{189}$ Rosenfeld 2010, p. 4.

${ }^{190}$ Vö.: Rosenfeld 2010, pp. 15-71.

191 Tribl 2018, pp. 155-158.

${ }^{192}$ Az alkotmány stabilitásának alapos vizsgálata meghaladja jelen tanulmány kereteit, itt csak utalok arra, hogy az örökkévalósági klauzulák alapesetben is erősíthetik az alkotmány stabilitását, amennyiben használják őket ilyen céllal. Vö.: Szakály 2018

${ }^{193}$ Jacobsohn 2010, pp. 34-82.
} 
(ii) A létrejövő alkotmányos berendezkedés identitása e három tényező konfrontatív viszonyban ölt testet az egyensúly biztosításával: a három faktor egymás által meghatározott, így azok változása is csak összhangban képzelhető el.

(iii) Az alkotmányos identitás egyik meghatározó tulajdonsága ezért a kontinuitás, ${ }^{194}$ vagyis az alkotmányos rendszer identitását egyetlen időpillanatban, zárt értékek katalógusával nem lehetséges kielégítően meghatározni. ${ }^{195} \mathrm{Az}$ alkotmányos berendezkedés statikus jelenségként értelmezhető, az annak kialakítására képes - organikusan fejlődő - entitás az alkotmányos alany.

(iv) Amennyiben egy adott időpillanatban nevesíteni kívánjuk egy alkotmányos rendszer identitásának elemeit, azok az alkotmányos rendszert alkotó tényezők (alkotmányos közösség, alkotmányozó hatalom, alkotmány) konfrontatív viszonyának eredményeként az alkotmány rendelkezései között, mint alkotmányos értékek és intézmények, alkotmányos alapelvek öltenek testet, amelyek megjelenhetnek az alkotmánybírósági / felsőbb bírósági esetjogban, mint identitáselemek. ${ }^{196,197}$

A fenti megállapítások ellenére azonban fontosnak tartom hangsúlyozni, hogy az alkotmányos identitás fogalmi keretei nem kiforrottak, sőt létezik olyan álláspont is, amely szerint az európai integrációban a tagálamok alkotmányos identitásának egzakt meghatározása nem is feltétlenül kívánatos. ${ }^{198}$ Anne Levade amellett érvel, hogy amíg az az alkotmányos identitás pontos tartalma homályba burkolózik, addig egyfajta megfontolt óvatosság betartásával elkerülhető a nyílt konfrontáció a tagállamok és az integráció, illetve az egyes tagállamok között. Ellenben attól a perctől kezdve, hogy kimondjuk: az alkotmányos identitás érinthetetlen és azt is meghatározzuk, hogy mit tekintünk konkrétan az alkotmányos identitás elemeinek (és milyen tartalommal), amelyet védeni

\footnotetext{
194 Vö.: Rosenfeld 2010, p. 41., Sulyok 2014, pp. 44-46.

195 Vö.: Rosenfeld 1995, pp. 1049-1111., 1049.

196 Vö.: Majtényi 2017, pp. 3-7.

197 Az Alkotmánybíróság formálódó joggyakorlatában Magyarország alkotmányos identitásának egyes elemeit, álláspontom szerint túlságosan tág körben vonta meg, mikor azt többek között alkotmányos értékek példálózó jellegű felsorolásával határozta meg, azonban az egyes elemekhez tartozó indokolás nélkül. Vö.: 22/2016. (XII. 5.) AB határozat, AB 2016, 1418, 64 - 65. pont. A magyarországi gyakorlattal jelen értekezés $\mathrm{V}$. fejezete részletesen is foglalkozik.

198 Vö.: Levade 2016, pp. 71-72.
} 
kívánunk, elkezdődik egyfajta direktebb összeütközés időszaka. ${ }^{199}$ Levade indokolásával, miszerint az alkotmányos identitás meghatározása konfliktusokat szülhet egyetértek, a következtetést, miszerint ezen konfliktusok elkerülése érdekében az identitáselemek markáns kinyilvánítása és védelme kerülendő, viszont már nem tudom támogatni. Az európai integrációt a közös szükségletek és érdekek, illetve az európai népek közötti hasonlóságok, hosszú idő alatt végül összecsiszolódó értékek, kell hogy összetartsák. Egy stabilizálódó, egységes értékrend kialakulásáig a közös szükségletek és érdekek, majd az értékrend. Ezek esetleges hiányában, amennyiben ennek a fajta integrálódásnak a megvalósítása nem lehetséges, úgy az integrációs folyamat más irányba terelésére van szükség, hiszen egy nem müködő rendszer fenntartása hosszú távon nem lehet érdeke az európai nemzeteknek. Jelen értekezésem elkészítése során folytatott kutatásom alapján hiszek abban, hogy az integrációs folyamat az egységesülés irányába folytatódhat, azonban olyan ütemben, és módon, amelyet az azt alkotó népek identitása - és így értékrendje! - lehetővé tesz. Bárhogyan is, ha félelemből nem határoznánk meg az egyes tagállamok alkotmányos identitásának elemeit, úgy az integrációt a félelem tartaná össze. Félelem annak müködésképtelenségétől, amely semmiképpen sem eredményez(ne) egy jobban müködő, stabilabb integrációs folyamatot.

A koncepció tartalmáról alkotott álláspontoktól függetlenül azonban lényeges, hogy az alkotmányos identitás kérdésében folytatott tudományos vita ne válhasson parttalanná. Ezért minden, a koncepció értelmezésére irányuló kísérlet szilárd jogelméleti alapokon kell, hogy nyugodjon. Habermas, Rosenfeld és Jacobsohn - Hegel filozófiájából kiindulva - átfogó elméleti alapokra helyezik az identitás alkotmányos koordináta rendszerben alkalmazott fogalmát, amelynek előfeltétele az identitást hordozó entitás meghatározása, amelyet Rosenfeld után „,constitutional self”-ként, vagy alkotmányos alanyként nevesíthetünk. ${ }^{200}$ Rosenfeld és Jacobsohn elméleteinek eredőjeként olvasható ki, hogy az alkotmányos identitás hordozója kizárólag a „constititional self” lehet, amely Jacobsohn tételeit alapul véve lényegében maga az alkotmányos rendszer, amely az alkotmányos közösség (nemzet), az általa felruházott alkotmányozó hatalom és az alkotmányozó hatalom letéteményesei által létrehozott alkotmány egymásra hatásaként értelmezhető. ${ }^{201}$

\footnotetext{
${ }^{199}$ Uo.

${ }^{200}$ Rosenfeld 2010, pp. 37-38.

201 Rosenfeld: 1995, pp. 1049-1111., Jacobsohn 2013, pp. 5-16.
} 
Az identitásképzés folyamatát a fentiek fényében a 4. sz. ábra szemlélteti.

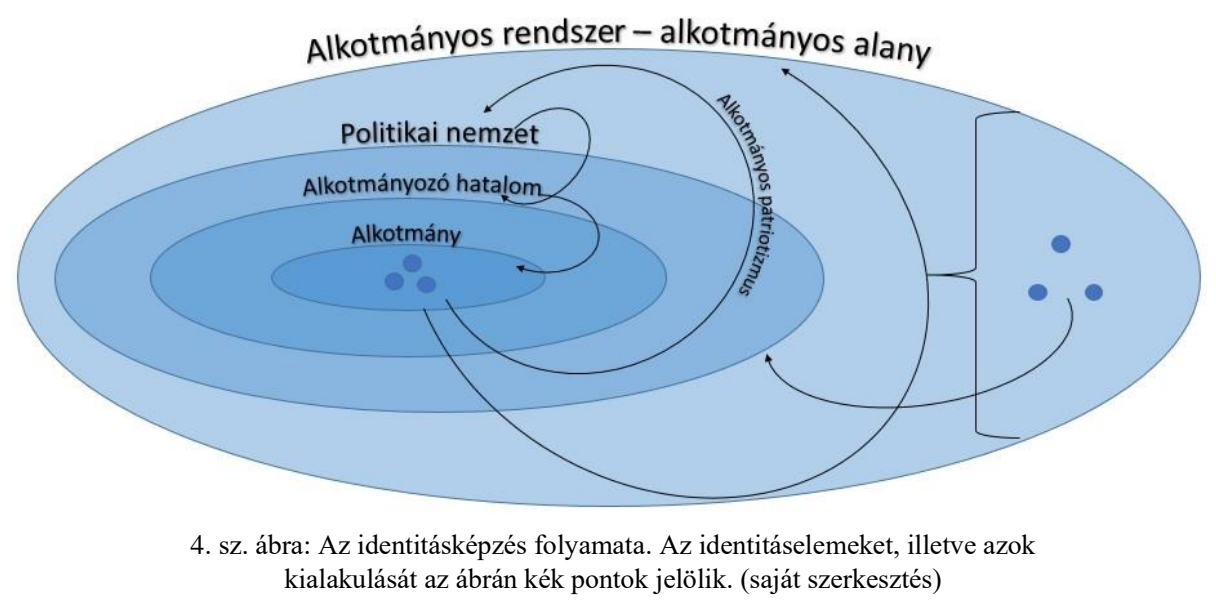

Az alkotmányos identitás koncepciójának elötérbe kerülése az utóbbi években különösen európai dimenzióban - a nemzetközi színtér globalizálódásának ${ }^{202}$ törvényszerü folyománya, tartalmának meghatározása pedig azért vált szükségessé az európai szupranacionális térben, mert az integráció közösségi keretében a tagállamok egyre szorosabb kapcsolatba kerülnek és így szükségszerüen konfrontálódnak is egymással. Egy, a természettudományból vett példán keresztül megvilágítva, az európai integráció tagállamainak egymással alkotott konfrontatív viszonya hasonló a részecskefizikában, a magfúzió során lezajlódó folyamatokhoz.

A magfúzió során két könnyebb atommagot közelítenek egymáshoz, amelyek azonos pozitív töltésüknek köszönhetően közelítésükkor először taszítják egymást (Coulombtaszítás). Ahhoz, hogy a két atommagot tovább közelítsük, a Coulomb-taszítás mértékével megegyező mértékü energiát kell befektetni. Amennyiben az atommagok kölcsönhatásából kialakuló taszítással megegyező, vagy attól nagyobb mértékű energia löki az atommagokat egymás felé, végül elérik azt a pontot, ahol egymásba olvadnak és egy nagyobb, nehezebb atommaggá egyesülnek. ${ }^{203}$ Hasonló folyamatok zajlanak le az európai integrációban egyesülő tagállamok esetén is: a globalizálódó környezet az európai nemzetállamokat egymás irányába mozdítja, azonban ez a természetes (nemzetközi) kapcsolaton túli távolság a tagállami alkotmányos és politikai berendezkedések relációjában kiváltja - az atommagokhoz hasonlóan - a tagállamok

202 Vö.: Halmai 2013, pp. 197-206.

${ }^{203}$ Vö: Szatmáry-Vinkó-Gergely-Keresztes 2013, pp. 12-14. 
között érvényesülő taszító hatást, amely az európai integráción belül tapasztalható jogi és politikai feszültségekben manifesztálódik. Az integrációs folyamatot végső soron - és hosszú távon - az határozza majd meg, hogy a tagállamok mind szorosabb együttmüködése iránti igény (vagy sokkal inkább szükség) legyőzi-e a közeledésből törvényszerüen keletkező feszültségeket. Ha elfogadjuk, hogy az európai integráció egy, a természettudományok által már feltárt, fizikai jelenséghez hasonló törvényszerüségen megy keresztül, akkor ebből további következtetéseket is levonhatunk. A részecskefizikában az egyesülés előtt álló atommagokat egyesítő erőhatás vagy legyőzi az ún. Coulomb-taszítást és ezáltal létrejön a nehezebb atommag, vagy a fúzió meghiúsul és az atommagok távolodni kezdenek, a taszító hatás pedig csökken.

Ezeknek a tagállamok közötti, pontosabban az integráció és a tagállamok közötti feszültségeknek a következménye, hogy szükségszerüvé válik az egyes tagállami alkotmányos specifikumok meghatározása, amelyek az adott tagállam alkotmányos berendezkedésének immanens elemei, annak „érinthetetlen lényegét” (kemény magját) alkotják. $^{204}$

Mindezek alapján megállapítható, hogy az alkotmányos identitás az alkotmányos rendszer (berendezkedés) természetének egy olyan jellemzőjeként is felfogható, melynek két fő funkciója, egyszersmind jelentősége az önmeghatározás, illetve a megkülönböztetés az alkotmányos rendszer (berendezkedés) egyedi jellemzői által. ${ }^{205}$ Meg kell jegyezni ugyanakkor, hogy az egyes alkotmányos értékek, alkotmányos elvek és intézmények kiemelt védelme és nevesítése a nemzeti alkotmányokban nem elegendőek ahhoz, hogy azokra, mint az alkotmányos identitás jegyeire tekinthessünk. Ehhez általában szükséges egy többlet elem: egyfajta megkülönböztetés a nemzeti alkotmánybíróság ${ }^{206}$ vagy az alkotmányozó által, amely deklarálja, hogy a védendő alkotmányos érték, alapelv, vagy intézmény az alkotmányos rendszerre meghatározó hatást gyakorol és így önmeghatározásának részévé válik.

\footnotetext{
${ }^{204}$ Vö: Fazekas 2015, p. 46.

205 Jacobsohn 2013, p. 5.

206 Sulyok 2015, pp. 27-39.
} 


\subsubsection{Alkotmányos patriotizmus}

E ponton úgy vélem szükséges kitérni az értekezésben már többször érintett, Habermas nevéhez köthetö alkotmányos patriotizmus (Verfassungspatriotismus) elméletére is, amelynek lényege Halmai szerint ,,arra utal, hogy a polgárok nem csupán az alkotmány alapelveinek elvont tartalmát, hanem mindenkori saját nemzeti történelmük kontextusából adódó konkrét jelentését tekintik a magukénak." ${ }^{207}$ Az alkotmányos patriotizmus központi szemléletmódja szerint az alkotmányos normák iránti elköteleződésnek kell meghatároznia a közösségeket, azaz úgy tekint az alkotmány normáira, mint a közösséget meghatározó, szervező erőre és nem, mint a közösséget meghatározó szervező erők manifesztációjára. ${ }^{208}$

Párhuzam vonható Habermas alkotmányos patriotizmus elmélete és Jacobsohn alkotmányos diszharmónia (constitutional disharmony) elmélete között, ${ }^{209}$ hiszen mindkét teória esetében az alkotmány normáira az alkotmányos közösség által adott reakció jelenti a vezérfonalat. ${ }^{210}$ Míg Jacobsohn szemléletében azonban az alkotmány „pusztán” egy az alkotmányos közösség identitását részben deklaráló és azt egyben alakítani képes tényezőként jelenik meg; a hangsúly az alkotmányos közösségen van (azaz mondhatnánk, hogy ,az alkotmány van a közösségért és nem a közösség az alkotmányért"). Habermas elméletében ellenben a hangsúly az alkotmányra, az alkotmány egyes rendelkezéseire tevődik át.

Megfordítva a gondolatmenetet, az alkotmányos patriotizmus szemléletmódja szerint inkább az alkotmánynak kellene formálnia az alkotmányos közösség identitását, mint sem a közösségnek az alkotmányos rendszer identitását. ${ }^{211}$ Ugyanakkor a két elméletben megjelenített szemléletmód ugyanannak az éremnek a két oldala: az alkotmány által hordozott tartalom és az alkotmányos közösség által arra adott válasz. A különbséget többek között abban érhetjük tetten, hogy az alkotmányos patriotizmus elmélete az alkotmányt (!) végső soron az azt létrehozó alkotmányos közösség (identitása) elé helyezi, tehát az alkotmány szupremáciájával egyfajta „kényszert” generál, vagyis az

\footnotetext{
${ }^{207}$ Halmai 2009, p. 42.

208 Vö.: Müller 2008

209 Jacobsohn 2010, pp. 1-35.

${ }^{210}$ Vö.: Jacobsohn 2013

211 Vö.: Müller 2008
} 
alkotmányos rendszer identitását nem az egyes tényezők (alkotmányos közösség, alkotmányozó hatalom és az alkotmány) dinamikus és folytonos konfrontációja, sokkal inkább az alkotmány dominanciája határozza meg. Ezzel szemben Jacobsohn az egyensúlyra törekszik: az alkotmány és az alkotmányos közösség kölcsönösen formálja egymást, a folyamat szempontjából egyenrangúak. (Jacobsohn e folyamat „eredményeiként” értelmezi az alkotmányos identitást.)

Látható tehát, hogy az alkotmányos patriotizmus az alkotmány és az alkotmányos közösség között létrejövő identitásformáló folyamat (a közösség mikor és milyen szimbolikus elemekkel képes azonosulni, azaz saját identitásának elemeként mikor, hogyan és mennyiben fogadja el az alkotmány szimbolikáját) egyfajta kívánatosnak tartott végeredményét fogalmazza meg az ,,alkotmány javára,” vagyis az alkotmányos patriotizmus valamelyest oktrojált természetet feltételez: az alkotmányban kifejezett értékek segítségével kívánja meghatározni magának az alkotmányos berendezkedésnek az értékrendjét, előre meghatározva annak egyes identitásjegyeit. ${ }^{212}$ Ezért úgy gondolom, hogy a Jacobsohn-féle megközelítés közelebb áll az alkotmányos rendszerek természetes „viselkedéséhez”, mert az egyensúlyra törekszik: az alkotmány formálhatja ugyan az azt életre hívó közösséget, de végső soron az alkotmányozó közösségnek kell meghatároznia az alkotmányozó hatalmon keresztül az alkotmányt és nem fordítva.

212 Rosenfeld felveti annak lehetőségét, hogy az alkotmányos patriotizmus egyfajta transznacionális alkotmányos identitásként fogható fel. Bővebben lásd: Rosenfeld 2010, pp. 258-279. 


\subsubsection{A nemzeti alkotmányos identitás}

Az alkotmányos identitás fogalmi körében jelentkező és legtöbbféleképpen értelmezhető - és értelmezett - fogalom a nemzeti alkotmányos identitás. ${ }^{213}$ Fontos azonban kiemelni, hogy a nemzeti alkotmányos identitás fogalma az európai integráción belül „meghonosodott” és alkalmazott fogalom, amelyen általában a tagállamok specifikus és egyedi alkotmányos identitását értjük. Az integráción kívül nem szükséges ilyesfajta differenciálás, hiszen nincs olyan közeg, amely szükségessé tenné azt. A nemzetközi viszonylatban, az Európai Unión kívül elegendő egy adott állam alkotmányos identitását nevesíteni, nem szükséges azt külön „,nemzetinek” is differenciálni, ahogyan azt az Unió esetében a Lisszaboni Szerződés teszi. Az integráción belül azonban az integráció és a tagállamok viszonya és „alkotmányos határaik” kijelölése indokolttá teheti a fogalmi pontosítást.

Más részről az alkotmányos identitás elvont kategória, amelyet az identitást hordozó szubjektum tölt fel konkrét tartalommal (számos megközelítést alkalmazva). E relációban értelmeznünk kell az alkotmányos rendszer funkcióját is, amely végső soron egy adott politikai közösség önszerveződésének és müködésének alapvető sajátosságait meghatározó és irányító szabályok összességeként fogható fel, amelyet a közösség saját viszonyainak meghatározására és a külső szereplőkkel szemben való egységes fellépés lehetőségének biztosítására hoz létre.

Alkalmazva az identitásformálással kapcsolatban levezetett „önformáló mechanizmust”, az alkotmányos identitásban az alkotmányos alanyt (a kollektív identitást hordozó szubjektumot) létrehozó politikai nemzet (az azt létrehozó közösség), tartalommal tölti fel a saját maga által életre hívott kollektív identitást. Az alkotmányos rendszereket az identitás szemüvegén át szemlélve azt mondhatjuk, hogy e rendszerek egyfajta perszonifikáció révén alkotmányos öntudattal rendelkező önálló szubjektumokká fejlődtek, amelyek természetükből fakadóan rendelkeznek önálló identitással. Ehhez a mechanizmushoz azonban nem ad hozzá, illetve nem vesz el az, hogy az adott

213 Kruzslicz Péter, jelen értekezés következtetéseitől eltérő álláspontra helyezkedik és a nemzeti alkotmányos identitás terminológiát alkalmazza. Vö.: Kruzslicz 2019, pp.111-161. A nemzeti alkotmányos identitás fogalmat alkalmazza Gisbert is, bár az alkotmányos identitásra utaló kontextusban. Vö.: Gisbert 2013, pp. 75-92. 
alkotmányos rendszer az európai integráció része. (A létrejövő identitás tartalmára természetesen a tagállamkénti önmeghatározás hatással van, az identitásformálás mechanizmusa azonban független az integrációban történő részvételtől.) Minderre tekintettel a nemzeti alkotmányos identitás fogalmának alkalmazása egyetlen kontextusban, az európai integráción belüli és kívüli megkülönböztetés során bírhat többlettartalommal, ezért álláspontom szerint a fogalom használata - mivel lényegében az alkotmányos identitásra vonatkozik - mellőzhető. 


\subsubsection{Nemzeti identitás}

Az Európai Unió jogrendszerében az alkotmányos identitás alkalmazásának forrásaként az EUSZ 4. cikk (2) bekezdése tekinthetö, amely kimondja: ,, az Unió tiszteletben tartja a tagállamoknak a Szerződések elötti egyenlöségét, valamint nemzeti identitását, amely elválaszthatatlan része azok alapvetö politikai és alkotmányos berendezkedésének, ideértve a regionális és helyi önkormányzatokat is. " Ezt gyakorlatilag megerösíti az EU Alapjogi Kartája, amelynek preambuluma rögzíti: „,az Unió hozzájárul e közös értékek megőrzéséhez és továbbfejlesztéséhez, miközben tiszteletben tartja az európai népek kultúrájának és hagyományainak sokféleségét, a tagállamok nemzeti identitását és központi, regionális és helyi közhatalmi szervezetét... "214

E rendelkezésekben az alkotmányos identitás terminus technicusa nem kerül nevesítésre, amely jelenség több okra is visszavezethető, ugyanakkor fogalmi bizonytalanságot is eredményez. Poiares Maduro AG fótanácsnoki indítványában a nemzeti és az alkotmányos identitásról a következőket írja:

„Igaz ugyan, hogy a tagállamok alkotmányos identitásának tiszteletben tartása az Európai Unió egyik kötelezettsége. Ez a kötelezettsége már a kezdetektöl fennáll. Ugyanis már az 1950-es évek elején elkezdődött európai projekt lényegét képezi, amely az államok politikai fennállásának megörzése mellett az integrációs folyamat elömozdítását jelenti. Ezt bizonyítja az a tény, hogy elsö alkalommal a Szerzödések azon felülvizsgálata alkalmával mondták ki kifejezetten e kötelezettséget, amelynek az elöírásaiban szereplö integrációs vívmányok szükségessé tették a tagállamok számára az e kötelezettségre való emlékeztetést. Így a Maastrichti Szerződés F. cikkének (1) bekezdése, majd az Európai Unióról szóló szerződés 6. cikkének (3) bekezdése ekképp rendelkezik: >>[a]z Unió tiszteletben tartja tagállamainak nemzeti identitását $\ll$. A nemzeti identitás nyilvánvalóan magában foglalja a tagállam alkotmányos identitását. "215

A főtanácsnoki álláspont alapján a nemzeti identitás tehát magában foglalja a tagállamok alkotmányos identitását, és funkcionális szempontból az alkotmányos identitás EU-n

\footnotetext{
214 Vö.: Martinico 2013, pp. 103-108.

215 C-213/07 Michaniki AE v Ethhniko Symvoulio Radiotileorasis and Ypourgos Epikrateias ügy, indítvány, 31. pont
} 
belül betöltött központi szerepét írja le, amelyre fentebb magam is utaltam. ${ }^{216} \mathrm{~A}$ főtanácsnoki indítvány megszületése óta eltelt időben mind a jogtudomány, mind a gyakorlat sok tekintetben meghaladta az abban foglaltakat az alkotmányos identitás koncepcióját illetően. Magam sem értek egyet többek között a főtanácsnoki indítvány nemzeti identitásról tett azon megállapításával, miszerint az az alkotmányos identitás részét képezné.

Ahogyan korábban láthattuk a nemzeti identitás - mint az alkotmányos közösség identitása - magában foglal olyan jellemzőket is, amelyek nem feltétlenül épültek be az alkotmányos berendezkedés identitásába, azaz meghatározzák ugyan az adott nemzetet, viszont nincs az alkotmányos berendezkedést alakító, meghatározó megfelelőjük. Ezzel szemben természetesen az alkotmányos identitásnak lehetnek olyan elemei, amelyek a nemzeti identitásból emelkedtek az alkotmányos identitás körébe, vagyis a nemzeti identitás egyes elemei alkotmányos identitássá alakulhatnak. Pontosan ebből kifolyólag nem értek egyet a főtanácsnoki kijelentéssel, miszerint az alkotmányos identitás a nemzeti identitás részét képezné, már csak azért sem, mert ahogyan arra Trócsányi is utal, a nemzeti identitás inkább politikai, mintsem jogi tartalmú fogalom. ${ }^{217}$ Vagyis kiindulva a korábbi fogalmi elhatárolásokból a helyes megközelítés álláspontom szerint az, ha az alkotmányos identitás fogalja magában a nemzeti identitás egyes elemeit, és semmiképpen sem fordítva, ${ }^{218}$ amint azt a fötanácsnoki álláspont rögzíti. ${ }^{219}$ Ahogyan Pavel Rychetsky írja, az alkotmányos identitás ugyan a nemzeti identitásból fakad, azonban annak nem szinonimája. 220

Ezen a ponton ismét szükségesnek tartom jelezni, hogy a társadalomtudományban és az Európai Unió kontextusán kívül értelmezett nemzeti identitás fogalmat el kell határolni az EUSZ által alkalmazott nemzeti identitás fogalomtól, amely talán elsőre önellentmondás, azonban az EUB határozott és kimerítő jellegű értelmezési gyakorlatának hiányában, illetve az eltérő alkotmánybírósági gyakorlatok tükrében

\footnotetext{
216 A főtanácsnoki indítvány 32. és 33. pontja szintén az alkotmányos identitás integrációban betöltött szerepéről értekezik, a nemzeti identitás a normaszöveggel összefüggésben kerül megjelenítésre.

${ }^{217}$ Vö.: Trócsányi 2014a, p. 72.

218 Vö.: Rosenfeld 2010, p. 10. és Rosenfeld 1995, p. 1049.

${ }^{219}$ Annál is inkább, hiszen ahogyan Trócsányi már idézett gondolatmenetében írja, a nemzeti identitás az alkotmányjog számára nehezen értelmezhető kategória.

${ }^{220}$ Rychetsky 2017, p. 95.
} 
kizárólag csak ebben az értelmezésben, illetve ennek az elhatárolásnak a megtételével alakítható ki a konzisztens jogértelmezés, illetve joggyakorlat.

Rosenfeld a nemzeti identitás fogalmát Anderson elméletéből kiindulva elemzi, ${ }^{221}$ és szintén arra a következtetésre jut, hogy az alkotmányos identitás szükségképpen elválasztandó más identitástoktól, így különösen a nemzeti identitástól. ${ }^{222}$

Alkalmazva az identitás elemzése során írottakat, a nemzeti identitás meghatározása során a kollektív identitással rendelkező szubjektum az alkotmányos közösség (nemzet), ${ }^{223}$ amelyet saját kontinuitásában szükséges vizsgálnunk. ${ }^{224}$ Mivel az identitás egyes jegyeinek megállapítása során a szubjektumot - létezésének kezdete óta meghatározó tényezőket kell figyelembe vennünk (dinamikusan) és a jelenből értelmeznünk (statikusan), ezért a politikai nemzetek tekintetében a nemzeti identitáshoz nem pusztán azok a meghatározó tényezők tartoznak, amelyek alapján egy nemzetet a jelenben elhatárolhatunk egy másiktól, mint pl. az adott nemzet nyelve, hanem azok a múltbéli események is, amelyek formálták az adott nemzet kollektív önmeghatározását. Pontosabban nem az adott nemzetek történelmében bekövetkezett események, sokkal inkább az azokhoz a jelenből való viszonyulás (ti. nemzeti emlékezet, múlttal való szembenézés) az, amely a nemzeti identitás elemét képezi, azaz a tény, hogy egy-egy sarkalatos esemény hogyan formálta a nemzet, illetve a nemzetet alkotó egyének önmeghatározását. (E folyamatok számos elemét megjelenítik például az egyes alkotmányok preambulumaiban. ${ }^{225}$ )

Amennyiben egy, a nemzetet érő ,inger”, vagy esemény olyannyira jelentős, hogy a nemzet önmeghatározására hatni tudjon és így formálja a közösség kollektív identitását, az esemény és az arra adott reakció beépül a nemzet öntudatába, vagyis nemzeti identitássá válik. (A kollektív identitást a közösséget létrehozó egyének identitása hozza

\footnotetext{
221 Anderson 2006

${ }^{222}$ Vö.: Körtvélyesi 2013, pp. 115-120.

223 Nem szabad azonban elfelejtenünk a kulturális nemzet és a politikai nemzet fogalom közötti szétválaszthatatlan kapcsolatot, hiszen a politikai nemzet „,nemzeti identitását” gyakorlatilag a kulturális identitás tölti fel tartalommal. Vö.: Bakk Miklós: A nemzeti identitás, mint politikai identitás. http://bakk.adatbank.transindex.ro/belso.php?k=2\&p=4170

${ }^{224}$ A politikai nemzet identitása különböző „,egyéb identitásokból” épül fel, úgy, mint a kulturális, vallási, történelmi identitás. Vö.: Hanák 1997, pp. 4-7.

${ }^{225}$ Vö.: Sulyok-Trócsányi 2009, pp. 81-106.
} 
létre és határozza meg, azonban mikor az már „önálló entitásként” viselkedik, a kollektív identitás változásai visszahatnak az azt létrehozó egyének identitására.)

A nemzeti identitás tehát szükségszerüen kapcsolódik ahhoz a közösséghez, amely az adott alkotmányos berendezkedést létrehozta, magában foglal azonban olyan jellemzőket is, amelyek meghatározzák ugyan az adott nemzetet, viszont nem épültek be annak alkotmányos berendezkedésébe. ${ }^{226}$ Igaz felmerülhetnek a nemzeti identitásnak az alkotmányban védendő elemei is, álláspontom szerint a nemzeti identitás és az alkotmányos identitás alapvető szinten, már az identitást hordozó szubjektum szintjén elválik egymástól: míg a nemzeti identitást hordozó szubjektum az alkotmányos közösség, a nemzet, addig az alkotmányos identitás hordozója maga az alkotmányos rendszer (az alkotmányos alany), amelynek a politikai nemzet csupán egy - meghatározó - alkotóeleme. Erre tekintettel igaz, hogy a két fogalom éles szétválasztása nem feltétlenül vezet helyes következtetésre, ezért egymással sokkal inkább a rész-egész viszonyában foghatók fel. Az alkotmányos és a nemzeti identitás ezen elhatárolása olvasható ki többek között a lengyel alkotmánybíróság gyakorlatából is, ahol nevesítetten kerül egymástól elkülönítésre az alkotmányos és a nemzeti identitás, amely azonban a fentiek szerint szorosan összetartozik. A lengyel gyakorlat szerint a nemzeti identitás elemeiként a hagyomány és a kultúra kerülnek nevesítésre. ${ }^{227}$

Miért akkor mégis a nemzeti identitás, mint terminus technicus, ha az a funkcionalitás szempontjából inkább az alkotmányos identitás kategóriájára utal? Álláspontom szerint a kérdés többek között az alkotmányos identitás fogalmának tisztázatlanságával magyarázandó: egy, az integráció fundamentumát képező dokumentumban nevesíteni további bizonytalanságokat eredményezne. A jelenség hasonló az EU „kvázi alkotmányos alanyiságához", vagyis ez esetben is funkcióját tekintve egy, az alkotmányos rendszerekhez köthető jelenség nélkülözi az „alkotmányos” jelzőt, amely így összhangban áll azzal, hogy a Szerződés, amelyben benne foglaltatik szintén csak funkcióját tekintve hordoz alkotmányi jelleget. Kérdés azonban, hogy mennyire jelent kevesebb instabilitást egy olyan - bár az alkotmány(os) jelzőt kétségkívül nélkülöző fogalom alkalmazása az Alapító Szerződések szintjén, amelynek értelmezési tartománya

${ }^{226} \mathrm{Pl}$. az alkotmányban nem rögzített nemzeti hagyományok esetében.

227 Vö.: Drinóczi 2016b, pp. 9-10. 
gyakorlatilag korlátlan és amelynek széles, az EUSZ 4. cikkén kívüli gyakorlata alakult ki az európai integrációtól függetlenül. Mindezekre tekintettel álláspontom szerint a Lisszaboni Szerződésben nevesített nemzeti identitás alatt a tagállamok alkotmányos identitását ${ }^{228}$ kell értenünk. Az EUSZ 4. cikkében foglalt szóhasználattal, illetve a szöveg tervezetének korai változataival jelen értekezésben a későbbiek során részletesen is foglalkozom.

228 Ahogyan azt Sulyok meg is jegyzi: Ami az EU számára nemzeti identitás, az a nemzeti alkotmánybíróságok számára csak alkotmányos identitás lehet. Vö.: Sulyok 2014, p. 8. és a „nemzeti identitás lisszaboni fogalmának" értelmezését - Sulyok 2014, p. 6. 


\subsubsection{Az alkotmány identitása és a tagállami identitás}

Trócsányi hipotetikusan kitér arra, hogy a Lisszaboni Szerződés szövegét helyesebb lenne tagállami identitásként értelmezni, hiszen a fogalom tartalmát meghatározó elemek a tagállamok államként történő önmeghatározására utalnak. ${ }^{229}$ Később a magyar szakirodalomban Drinóczi a fogalmi keretek rendszerbe foglalása érdekében már nem csak felveti, de bevezeti a „tagállami identitás” kifejezés alkalmazását. ${ }^{230}$ A korábban kifejtettek alapján úgy vélem az EUSZ szövege, tartalmát és funkcióját tekintve az alkotmányos identitásra utal, amely azonban fogalmilag, szükségképpen magában foglal egyfajta tagállami identitást is. Ezért jelen sorok szerzője szerint kétséges lehet egy újabb, összegző fogalom alkalmazásának hatékonysága. Álláspontom szerint a nemzeti identitás EUSZ 4. cikk szerinti értelmezése az uniós jog szintjén, illetve az alkotmányos identitás jogtudományi fogalmának meghatározására tett kísérletek a jogtudomány szintjén vezethetnek el a jövőben az alkotmányos identitás koncepciójának, illetve fogalmi rendszerének letisztulásához, míg a fogalmi háló bővítése csak további bizonytalanságokat hív életre, illetve az ugyanarra a jelenségre alkalmazott - már egyébként is túl széles skálát felvonultató - fogalmak bővülését eredményezné.

Az alkotmányos identitással összefüggésben alkalmazott fogalmi elhatárolások során szintén szükséges elhatárolni az alkotmány identitását (az ún. alkotmányidentitást) az alkotmányos identitás fogalmától, noha a jogirodalomban találkozhatunk olyan nézetekkel, miszerint a két fogalom tulajdonképpen szinonim jelentéstartalommal bír. ${ }^{231}$

Drinóczi szerint az alkotmányos identitás, mivel annak meghatározása végső soron alkotmányértelmezést igényel, csak annyiban állhat fenn, amennyiben az identitás az alkotmány valamely rendelkezésével van kapcsolatban. Álláspontja szerint lényegében a nemzetet meghatározó nemzeti identitás jegyei, amennyiben az alkotmányban rögzítésre kerülnek, hozzák létre az alkotmányos identitást. ${ }^{232}$ Ezért, illetve mivel az alkotmányos demokráciában „mindennek az alapja az alaptörvény”, következtetése szerint az alkotmányos identitás minden esetben visszavezethető és leszükíthető az alkotmány

\footnotetext{
${ }^{229}$ Vö.: Trócsányi 2014a, p. 77. A kérdést úgy vélem érdemes összevetni Besselink a kérdésben alkotott, ám valamelyest eltérö következtetéseivel, vö.: Besselink 2010, p. 42.

${ }^{230}$ Vö.: Drinóczi 2018a

${ }^{231}$ Vö: Drinóczi 2016b, pp. 33-34.

${ }^{232}$ Uo.
} 
vizsgálatára és értelmezésére, illetve az alkotmányos identitás nem más, mint az alkotmány identitása. ${ }^{233}$

Ezzel szemben Sulyok szerint az alkotmányos identitás fogalma nem választható el élesen az alkotmány identitásától, azonban a distinkció elvégezhető. ${ }^{234}$ Többek között felteszi a kérdést, hogy bármely alkotmánnyal rendelkező entitás de facto rendelkezik-e identitással, vagy az identitás már az alkotmányból következik? (Megjegyzendő, hogy Sulyok az identitást az autonómia, a szuverenitás és az „egyéniség” egységeként írja le, ${ }^{235}$ míg az alkotmányidentitást és az alkotmányos identitást rész-egész viszonyban határozza meg, ${ }^{236}$ utalva a német alkotmánybíróság joggyakorlatára, amelyben az alkotmány identitásaként rögzített fogalom mára az alkotmányos identitás doktrínájává nőtte ki magát. ${ }^{237}$ )

A fent ismertetett álláspontok közül nem értek egyet azzal, hogy az alkotmányos identitás fogalmát és az egyes identitásjegyeket az alkotmány identitásával kellene azonosítanunk. Egyetértek azonban Sulyok azon - európai integráció tagállamainak alkotmánybírósági gyakorlatán nyugvó - álláspontjával, amely szerint a két fogalom bár elválasztható ugyan, éles elkülönítésük nem lehetséges.

Szükségesnek tartom ugyanakkor a két fogalom elhatárolásának további szempontját meghatározni az identitást hordozó entitások elkülönítésével. Mint azt az identitás általános fogalmának vizsgálata során láthattuk, az identitás, mint önmeghatározás minden esetben feltételez egy, az identitást hordozó szubjektumot. E szubjektum a rosenfeldi és jacobsohni elméleti alapvetésből fakadóan az alkotmányos alany, amely a politikai nemzetet alkotó alkotmányos közösség, az alkotmányozó hatalom és az alkotmány szimbiotikus közösségeként határozható meg. ${ }^{238} \mathrm{~A}$ vázolt jogelméleti alapon

\footnotetext{
${ }^{233}$ Drinóczi 2016b, p. 34.

${ }^{234}$ Sulyok 2016b, p. 341.

235 Sulyok 2016b, p. 342.

236 Sulyok 2016b, p. 356.

${ }^{237}$ Sulyok 2016b, p. 343.

${ }^{238}$ Megjegyzendő, hogy vizsgálódása során Drinóczi Tímea a nemzet önmeghatározásának eredményeként nevesíti az alkotmányozó hatalom létrejöttét, az alkotmányozást, illetve az alkotmányozás során megszülető alkotmányt, amely folyamat az állami főhatalom gyakorlására irányul. Drinóczi olvasatában e kölcsönhatás eredménye azonban nem az alkotmányos identitás, hanem a nemzeti, illetve a népszuverenitás. E gondolatot talán annyival szükséges kiegészíteni, hogy bár e folyamat célja és eredménye valóban a szuverenitás (gyakorlása), azonban a folyamat egyedi, (tag)államonként
} 
nyugvó szempontrendszert tekintve, az alkotmányos identitás tehát már forrásában, az identitást hordozó entitásban elkülönül az alkotmány identitásától. Ahogyan az alkotmány meghatározó része az alkotmányos rendszernek és berendezkedésnek, úgy az alkotmány identitása meghatározó részét képezi az alkotmányos identitásnak, annál is inkább, hiszen a három tényező (alkotmány, alkotmányozó hatalom, alkotmányos közösség) egymásra hatásának „eredménye” az alkotmány egyes rendelkezéseiben manifesztálódik.

E kölcsönhatás - ti. az alkotmányos rendszert meghatározó három faktor - belső megnyilvánulása - ahogyan arra Drinóczi is utal ${ }^{239}$ - alkotmányi rendelkezésekként (akár alkotmánymódosításként is) manifesztálódhat, azonban az e szereplők közötti konfliktusok eredményei egyben olyan meghatározó alkotmányos vívmányokként realizálódhatnak, amelyeket az adott alkotmányos rendszer külső megnyilvánulásaiban védendő értékként azonosít. Ez az értelmezés pedig egyúttal felveti az alkotmányos identitás külső és belső oldalának vizsgálatát, amellyel az értekezés 3.5. és 4.1. fejezete foglalkozik.

meghatározható specifikumainak összessége már jelentheti az alkotmányos identitás egyes elemeit. Vö.: Drinóczi 2016b, p. 33.

${ }^{239}$ Drinóczi 2016b, p. 33. 


\subsection{Az alkotmányos identitás fogalomrendszere}

Összegezve az alkotmányos identitás formálódásának mechanizmusát az identitásképzés folyamatára és az alkotmány fogalmára tekintettel, az alábbi megállapítások tehetők:

(i) Az alkotmányos identitás forrása az állam kialakítására képes, nemzetet alkotó, homogén emberi csoport - a démosz -, mint önálló entitás, amely a természetes alkotmány időszakát követően a strukturális önszerveződés érdekében létrehozza saját alkotmányos berendezkedését.

(ii) A nemzetnek - mint homogén közösségnek - ezen identitásképzés szempontjából megközelített felfogása alkotmányos közösségként nevesíthetö.

(iii) A szuverenitás az alkotmányos közösség által létrehozott entitás (az állam) fundamentális ismérve, amely végső soron az alkotmányos közösséget megillető önrendelkezés, a döntés jogának leképeződése, majd összpontosulása az állam létrejövetelét követően, amely forrása és egyben előfeltétele az állami struktúra és társadalmi berendezkedés, vagyis az alkotmányos rendszer létrejövetelének.

(iv) Az alkotmányos berendezkedés kialakítása az alkotmányos közösség társadalomba rendeződésének szükségszerü következménye, amely azonban feltételezi a kialakított struktúrával szemben támasztott azon követelményt, hogy az megfeleljen az életre hívó társadalom karakterisztikájának: az alkotmányos közösség tagjai képesek legyenek azonosulni a létrejövő struktúrával, ezáltal képesek legyenek azt elfogadni, vagyis a közösség kollektív identitása visszatükröződjön az általa megalkotott struktúrán.

(v) Az alkotmány egyrészről forrása annak az állami és társadalmi rendnek, amelyben az alkotmányos közösség létezik, másrészröl meg is testesíti azt: az alkotmány (elválaszthatatlan egységet alkotva létének forrásával) szintén forrása, egyúttal megtestesítője lesz az állami szuverenitásnak.

(vi) Az állami, társadalmi struktúrának meg kell felelnie az azt életre hívó közösség identitásának és ennek az identitásnak tükröződnie kell az alkotmányos berendezkedést megtestesítő és konstituáló dokumentumban, az alkotmányban is. 
(vii) Az alkotmányos közösség által - a szuverenitást kifejező alkotmányon keresztül - létrehozott alkotmányos rendszer (berendezkedés) az adott alkotmányos közösségre jellemző egyedi értékeket, intézményeket, társadalmi szervező elveket hív életre, amelyek egyediesítik, jellemzik és meghatározzák nem csak az alkotmányos közösséget, de már magát az alkotmányos berendezkedést is.

(viii) Ezeket a tényezőket meghatározza az alkotmányos közösség identitása (a nemzeti identitás), illetve az alkotmányos berendezkedést kialakító valamennyi tényező (alkotmányos közösség, alkotmányozó hatalom, alkotmány) egymással folytatott konfrontatív viszonya.

(ix) Az e konfrontatív viszonyból fakadó eredményként foghatók fel az alkotmányos identitás egyes elemei, amelyet egyúttal meghatároz az a fejlődési folyamat is, amelyen az alkotmányos berendezkedés keresztülmegy.

Álláspontom szerint az alkotmányos identitás koncepcióját - jogelméleti szempontból Rosenfeld és Jacobsohn tételeit összehasonlítva, kettejük rendszerének eredőjeként érthetjük meg a legtökéletesebben. Rosenfeld a hegeli filozófia alapján egy szilárd elméleti alapot fektet le, még Jacobsohn rendszerében az alkotmányos identitás gyakorlati megvalósulását követhetjük nyomon és e révén érthetjük meg annak természetét.

Az alkotmányos identitás jelentőségét és alkalmazhatóságát az európai szupranacionális térben az integráció és a tagállamok viszonyában fedezhetjük fel, mint a szuverenitástranszfer lehetséges határvonalát. Chronowski szerint a „szuverén állam föhatalma oszthatatlan, de az államhatalom gyakorlása megosztható és megosztandó, "240 vagyis az állam nem szuverenitását, hanem az abból fakadó döntési jogosultságok egy részét ruházza át a szupranacionális szintre (szuverenitástranszfer). Chronowski álláspontja szerint a hatáskörtranszfer korlátja, hogy az nem vezethet az állam felbomlásához vagy megszűnéséhez. Chronowski e határt „az állam fundamentális alkotmányos elvei és az alapvető jogok" mentén húzza meg. ${ }^{241}$

${ }^{240}$ Chronowski 2005, p. 49.

${ }^{241}$ Uo. 
Álláspontom szerint - összhangban a tagállami alkotmánybíróságok formálódó joggyakorlatával, a Lisszabon-határozatokkal ${ }^{242}$ - a döntési jogosultság átengedésének korlátját ettől jóval tágabb körben kell megszabni és ennek egyik szegmense az alkotmányos identitás. ${ }^{243}$ Másképpen megfogalmazva, a döntési jogosultság átengedése (hatáskörtranszfer) során egyetlen állam sem csupaszíthatja le önmagát annyira, hogy csak ,az állam fundamentális alkotmányos elvei” maradjanak, hiszen ebben az esetben fennállna a veszélye, hogy a tagállam elveszíti történelméből és egyediségéből fakadó (akár alkotmányos, akár kulturális, stb.) sajátosságait, Jacobsohn szavaival élve valami teljesen mássá alakulna, mint ami. ${ }^{244}$

Úgy vélem az alkotmányos identitás elmélete alkalmas lehet annak a határnak a megvonására, hogy egy, az európai integrációban részes tagállam az állami szuverenitásból fakadó „önrendelkezési jogról”, alkotmányos berendezkedését érintő döntési jogosultságról a szuverenitástranszfer folytán milyen körben mondhat le az integráció javára. Ebben az értelemben, ha a szuverenitás a döntés jogaként értelmezhető, akkor az európai szupranacionális térben az alkotmányos identitás ennek negatív korlátja, amely meghatározza, hogy a tagállamok milyen döntéseket (már nem) engedhetnek át az integrációnak.

Ezt az értelmezést az EUSZ 4. cikke valamelyest tovább szükíti, mikor az identitásklauzulát és az alapvető állami funkciók unió általi tiszteletben tartását elkülönülten, egy bekezdés alatt, de eltérő fordulatokban szabályozza. Az uniós klauzula értelmezési kérdései ezért elvezetnek egy további distinkcióhoz: az egyedi, tagállamra jellemző identitás-elemek - vagyis tulajdonképpen a szüken értelmezett alkotmányos identitás védelme az EUSZ 4. cikk (2) bekezdés első fordulata, még a tényleges hatáskörtranszfer körébe tartozó - valamennyi tagállamra azonos tartalommal vonatkozó kompetenciakérdések a második fordulat szerint ítélendők meg. Ez a distinkció az alkotmányos identitás tartalmának és alkalmazhatóságának szükítő értelmezéséhez vezet, amellyel részletesen az értekezés 4.1. fejezete foglalkozik.

\footnotetext{
${ }^{242} \mathrm{Az}$ egyes Lisszabon-határozatok bővebb ismertetését az alkotmányos identitással összefüggésben bővebben lásd: Sulyok 2014, pp. 51-60, illetve Drinóczi 2016b, pp. 7-14., stb.

${ }^{243}$ Vö.: 22/2016. (XII. 5.) AB határozat

244 Jacobsohn 2013, p. 1.
} 
Szem előtt tartva az alkotmányos identitásról folytatott tudományos viták során formálódó konszenzust, amely szerint az alkotmányos identitás fogalma általános jelleggel (és elfogadottsággal) ezidáig nem került meghatározásra - mi több, találkozhatunk olyan állásponttal is, amely szerint annak meghatározása nem is kívánatos ${ }^{245}$ - jelen értekezés keretei között szükséges a fogalom meghatározása annak érdekében, hogy az európai integráció alkotmányértelmezőinek joggyakorlatában élő és mind hangsúlyosabbá váló fogalom kézzelfoghatóvá, az európai integráció szupranacionális jogrendszerében betöltött szerepe körülhatárolhatóvá, funkciója meghatározhatóvá váljon.

E céltól vezérelve, annak szem előtt tartásával, hogy az alkotmányos identitás végső értelmezése és felfogása (ezáltal fogalma) a tagállamok alkotmányértelmezőinek joggyakorlatában kell, hogy testet öltsön, a rendelkezésre álló alkotmánybírósági (legfelsőbb bírósági) joggyakorlat és tudományos eredmények alapján az alkotmányos identitás (általános jellegü) jelen értekezés során alkalmazott fogalmát az alábbiakban határozom meg: A tagállami alkotmányos rendszerek önmeghatározásaként, az alkotmányos berendezkedéseket meghatározó olyan történelmi eredettel rendelkezö alapvetö alkotmányos értékek, elvek és intézmények rendszere, amelynek tiszteletben tartása az EUSZ alapján az Unió kötelezettsége. Az alkotmányos rendszerrel (berendezkedéssel) együtt járó, annak egyediségét megtestesitő olyan minöség, amely az alkotmányos közösség, az alkotmányozó hatalom és az alkotmány konfrontatív viszonyának eredményeként a nemzeti alkotmányokban, alkotmányerejü törvényekben manifesztálódik.

Ahhoz, hogy a koncepció a jövőben a szupranacionális tér egyik (alkotmányos) szervező elvévé váljon és így elősegítse az európai integrációban fennálló feszültségek mérséklődését, szükséges a fogalommal való bánásmód állandósulása, ${ }^{246}$ amelynek azonban előfeltétele egy megfelelően körülhatárolt, szilárd elméleti alapvetés és az alkotmányos identitással összefüggő fogalmak meghatározása és egymástól való elhatárolása. Ennek kialakításához kíván hozzájárulni jelen értekezés II. fejezete, míg a III. fejezetben a szupranacionális tér sajátosságait vizsgálom a szuverenitás szemszögéből.

${ }^{245}$ Levade 2016, p. 72.

${ }^{246}$ Rychetsky 2017, p. 98. 


\section{Szupranacionalitás, szuverenitás és az alkotmányos paradoxon}

\subsection{A többszintü alkotmányosság rendszere és az alkotmányos paradoxon}

Az Európai Unió, a „közös európai projekt”, mint az európai kontinens valaha létezett legsikeresebb „,béke-projektje” közel 70 éves történelme során képes volt arra, amelyre egyetlen más korábbi európai államközi együttműködés sem: tartósan megteremteni a békés együttmüködést az európai nemzetállamok között. Mindez nem jelenti azt, hogy az európai integráció képes lett volna a történelem valamennyi európai szembenállását kevesebb, mint egy évszázad alatt eloszlatni ${ }^{247}$, viszont képes volt arra, hogy a korábban fegyverrel vívott csatákat a tárgyalóasztal körül megvívott csatákra váltsa fel. Az integráció folyamata természetesen összetett jelenség.

A tagállamok számára megnyugtató a gondolat, hogy az integrációs folyamatban a tagállami szuverenitásból fakadó, önálló döntés volt az, amely a tagállam integrációs részvételét biztosította és ez az akarat az, amely a tagállamot az integráció keretén belül tartja, ezáltal is hozzájárulva a közös európai projekthez. Mindez természetesen formális, jogi szempontból igaz és helytálló. Nem szabad azonban figyelmen kívül hagynunk az alábbi fontos kérdéseket, amelyek a tagállamok mozgásterét az integrációban meghatározzák:

(i) A részvétel és együttmüködés formális aktusai mögött mennyire szuverén és mennyire szabad az az akarat, amely a tagállamok csatlakozási igényét és részvételi hajlandóságát megalapozza? ${ }^{248}$

(ii) Létezik-e a szuverén európai nemzetállamok számára más alternatíva, mint a valamilyen szintű részvétel az európai integrációban? Mik azok a motívumok, amelyek a résztvevő tagállamokat arra késztetik, hogy szuverenitásukból fakadó egyes jogköreik átengedésével egy nemzetek feletti jogrendszer részévé váljanak?

A felvetett kérdések számtalan módon megválaszolhatóak, azonban úgy vélem minden válaszban közvetlenül vagy közvetetten meg kell, hogy jelenjen az elöny motívuma:

\footnotetext{
${ }^{247}$ Szemléletes példáját nyújtja ennek maga a Brexit is.

${ }^{248}$ Megjegyzést érdemel, hogy Habermas az európai államok „kifelé irányuló szuverenitását” már 1976ban (!) anakronisztikusnak minősítette. Vö.: Habermas 1994, pp. 164-165.
} 
azon, főként gazdasági előnyöké, amelyek az európai integráció tagállamait az együttműködés tényéből fakadóan megilletik. A puszta előnyök azonban nem jelentenének elegendő motivációt az állam számára, hogy egy, a természetéből fakadó legfontosabb attribútumot, a szuverenitást korlátozni képes nemzetek feletti jogrendszer részévé váljon. Ehhez többre van szükség: közvetlen, vagy közvetett kényszerre. ${ }^{249}$ Olyan környezeti behatásokra, amelyek nem hagynak más lehetőséget a leendő tagállam számára, mint a csatlakozást, a részvételt.

Az integráció kezdeti időszakában az együttmüködés csak gazdasági előnyt jelentett, nem mellesleg a hosszútávú béke megteremtésének lehetőségét ígérte a résztvevő tagállamok számára. Az integráció szerveződése azonban párhuzamosan halad a technológia fejlődése által indukált globalizáció folyamatával, amely az integráció szerveződésétől függetlenül ugyan, de azzal párhuzamosan fejlődött és formálta át azt a nemzetközi teret, amelyben az integráció gondolata megszületett. ${ }^{250}$ A globalizálódó nemzetközi térben pedig jelenleg sokkal inkább gazdasági és politikai erőközpontokról beszélhetünk, mint nemzetállamokról, így a kérdés mára az, hogy létezik-e tényleges alternatíva az európai államok számára, mint az integrációs részvétel? Ismételten a fizika világából kölcsönzött analógiával élve a globalizációs, főként gazdasági hatások azok, amelyek mintegy centrifugális erőként a tagállamokat az integráció felé sodorják. ${ }^{251}$

Az alkotmányos identitás problémájának és európai alkalmazhatóságának megértéséhez szükséges, hogy nevesítsük azt a koordináta rendszert, amelyben a fogalmat meghatároznunk, majd alkalmaznunk kell. E koordináta rendszer a többszintü alkotmányosság (multilevel constitutionalism) fogalmával írható le, ${ }^{252}$ amelynek meghatározásához egy még távolabbi jelenségből kell kiindulni, amely pedig a globalizáció $^{253}$ jogrendszerekre, jelen esetben alkotmányos rendszerekre gyakorolt hatása. ${ }^{254}$

\footnotetext{
${ }^{249}$ Lásd a Coulomb-taszítást legyőző erőhatást a fúziós folyamatoknál, amely a két könnyebb atommagot egymás irányába, az egyesülés felé kényszeríti.

${ }^{250}$ Vö.: Fejes 2014a, pp. 112-115.

${ }^{251}$ Vö.: Orbán 2020, pp. 7-13.

${ }^{252}$ Vö: Gárdos-Orosz 2019, Vincze 2009, illetve egy szélesebb merítést alkalmazva Drinóczi 2017a vonatkozó fejezetei.

${ }^{253}$ A globalizáció alkotmányjogra, nemzeti alkotmányos rendszerekre gyakorolt hatását bővebben lásd: Tushnet 2008

${ }^{254}$ Trócsányi 2014a, p. 11., p. 23
} 
Figyelemre méltó distinkciót alkalmaz Chronowski Nóra, aki különbséget tesz a globális alkotmányosság és az alkotmányjogi globalizáció fogalmai között. Chronowski globális alkotmányosság alatt lényegében az „alkotmányozásban, alkotmányosodásban, alkotmányos jogalkotásban és jogalkalmazásban” kimutatható globalizásciós hatások vizsgálatát érti, míg az alkotmányjogi globalizációra, mint a nemzetközi jog alkotmányosodására, állami alkotmányjogra gyakorolt hatására ${ }^{255}$, illetve az alkotmányjogi megoldások közelítésének folyamatára utal. ${ }^{256}$

A globalizáció alkotmányos rendszerekre gyakorolt hatása összetett jelenség, amelyet általánosságban vizsgálva az egységesülő alkotmányos követelmények ${ }^{257}$ (i) és a nemzetközi szervezetek jogrendszerekre gyakorolt intézményi hatásán keresztül (ii) ${ }^{258}$ közelíthetünk meg. ${ }^{259} \mathrm{Az}$ állam nemzetközi szerepvállalása, nemzetközi szervezetekben történő részvétele által jogi kötelezettségeket teremt saját maga számára. A legtöbb esetben már önmagában a szervezethez csatlakozás tényével, vagy bi- és multilaterális nemzetközi szerződésekben való részvételével, illetve minden ilyen jellegü szerep- és kötelezettségvállalásával az állam formálja, alakítja a saját jogi berendezkedését.

Míg a legmeghatározóbb nemzetközi egyezményekben való részvétel esetében is azonban az állam, mint önálló, szuverén szereplő jelenik meg. Nemzetközi egyezmény útján keletkező szabály a szuverenitás ernyőjén belül kötelező erejű magatartási szabályt csak a szuverén döntésével és jóváhagyásával állapíthat meg. Vagyis a globalizáció hatásai szükségszerủen, azonban a szuverén „önként” vállalt, egyedi döntése nyomán érvényesülhetnek. A nemzetközi szervezetek és nemzetközi egyezmények, ugyan rendezhetnek az állam jogrendszerét meghatározó kérdéseket, sőt, hathatnak - és szükségszerüen hatnak is - az állam önmeghatározására, mégsem jelentenek feloldhatatlan alkotmányjogi problémát, hiszen az államnak, mint szuverénnek, a nemzetközi jog alanyának kapcsolatát kell rendeznünk más szuverénekkel és mint ilyen,

\footnotetext{
255 Pokol Béla a jelenséghez kvázi „,személyi oldalról”, az egyes irányzatok mögött húzódó érdekcsoportok oldaláról közelít. Az általa alkalmazott szemlélet mindenképpen figyelemre méltó, azonban a kérdést gyakorlatilag egészében politikai síkra tereli, értekezésem súlypontjában pedig a jogelméleti, alkotmányjogi megfontolások állnak, így jelen helyen csak utalok Pokol Béla vonatkozó munkásságára. Vö.: Pokol 2018, Pokol 2019.

${ }^{256}$ Chronowski 2015, pp. 20-21.

257 Vö.: Halmai 2013, pp. 15-18.

${ }^{258}$ Halmai 2013, pp. 27-29.

${ }^{259}$ Vö.: Mravik 2016
} 
bár a nemzetközi jognak megvannak a maga kihívásai, nem jelentenek államelméleti problémát. ${ }^{260}$

Nem mondható ki ugyanez azonban az európai integráció esetén, amelynek keretében megvalósuló államok közötti együttmüködés átmenetet képez a globalizációs folyamatok európai államokra gyakorolt hatása és az államfejlődés egy sajátos jelensége között. ${ }^{261}$ Bár az Európai Unió egy nemzetközi szerződésen alapuló nemzetközi szervezet, ${ }^{262}$ azonban már felülemelkedett a „nemzetközi szerződésen alapuló nemzetközi szervezet” mivoltán és „sajátos jogrendszert” alkotott, amelynek legfőbb jellemzője a szupranacionalitás, a nemzetek felettiség. ${ }^{263}$ Vincze - nemzetközi szakírókra utalással a szupranacionalitás legfőbb jellemzőjeként a nemzetközi szervezet azon képességét emeli ki, amellyel tagállamait azok akarata ellenére is meghatározott cselekvésre kötelezheti. ${ }^{264}$ A szupranacionalitás e központi eleme, az európai integráció fejlődésének e pontja az, ${ }^{265}$ amelyet a legteljesebben úgy vélem alkotmányos szingularitásként ${ }^{266}$ írhatunk le.

Ezen a ponton születik meg a szuverenitástranszfer ${ }^{267}$ intézménye és annak szükségessége, az osztott / fenntartott szuverenitás fogalma ${ }^{268}$, egyúttal jelenik meg a szuverenitáselméletek alkalmazhatóságának megkérdőjelezése az integráción belül és jön létre - a tudományos dialógusban egyre kevésbé szívesen látott fogalomként - a szuverenista-integrista ellentét, mint a tagállamok és az integráció közötti feszültség lásd korábban a Coulomb-feszültségnél írtak - manifesztációja. Az így megszülető szupranacionális jelleg, a nemzetekfelettiség következménye az alkotmányos

\footnotetext{
${ }^{260}$ A szuverenitás fogalma, illetve korlátozhatósága, korlátozottsága természetesen ezekben az esetekben is folyamatos vita tárgyát képezi. Például: Mravik 2016, pp. 18-20, Blutman 2019, pp. 87-88, Halmai 2013, pp. 17-29, stb.

${ }^{261}$ Vö: Fejes 2014b

262 Dezső-Vincze 2012, p. 18

${ }^{263}$ Uo. 20.

264 Uo.

${ }^{265}$ Az Európai Unió jogelőd szervezetei, az Európai Szén- és Acélközösség, az Európai Atomközösség, és az Európai Gazdasági Közösség nem rendelkeztek e tulajdonsággal, nem vetődtek fel az Uniót jelenleg jellemző alkotmányjogi problémák. Vö.: Vincze-Chrnowski 2018, p.21.

266 Szingularitás: a technológiai fejlődés és a társadalmi változások felgyorsulnak, olyan módon és sebességgel változtatva meg a környezetet, amit a szingularitás elött élők képtelenek felfogni vagy megbízhatóan megjósolni.

267 Vö.: Vincze - Chronowski 2018, pp. 375-450, Varga Zs. 2016b, Balogh-Békési 2008

${ }^{268}$ Osztott szuverenitásról bővebben lásd: Vincze 2009. A fenntartott szuverenitás elvéről lásd: 2/2019. (III.

5.) AB határozat [23] pontját.
} 
paradoxon, ${ }^{269}$ vagy Frankenstein szindróma (,, You are my creator, but I am your master - obey!” - Mary Shelley: Frankenstein), ${ }^{270}$ amely szerint a szuverén jogrendszert megtestesítő alkotmány felhatalmazása révén az állam olyan jogrendhez csatlakozik, amelynek egyes rendelkezései feltétlen érvényesülést követelnek, így - az Európai Unió Bíróságának döntése értelmében ${ }^{271}$ - a szuverén tagállamok alkotmányainak rendelkezésével szemben is. ${ }^{272}$

A szupranacionalitással kapcsolatban szükséges azonban hangsúlyozni, hogy az nem egyfajta oktrojált, az európai nemzetek akaratán kívülálló „külső kényszer.” Ellenkezőleg: a szupranacionális jelleg annak felismerése, hogy az európai nemzetek nem készek a föderális berendezkedés létrehozására - vö. az európai alkotmányról, illetve Alkotmányszerződésről szóló fejezetet -, azonban a globalizálódó környezet szükségessé teszi egy szorosabb együttműködés kialakítását. A szuparanacionalitás tehát jelen pillanatban a legszorosabb együttmüködési formának tekinthető, amelynek kialakítására az európai nemzetek készen álltak, illetve készen állnak. Weiler szerint a szupranacionalitás az alkalmazkodás kumulatív mintája, amelynek keretében az együttmüködő tagállamok közös érdekeiket magasabb szintre juttatják, miközben - az eltérő érdekekre tekintettel - kompromisszumok elérésére törekednek. ${ }^{273}$ Weiler kiemeli azonban, hogy a közös érdekek magasabb szintre emelése és a kompromisszumok szükségességének vállalása önkéntes, szuverén döntésen alapul, ${ }^{274}$ amely döntést követően a tagállamokkal szemben már követelményként jelentkezik, hogy a szupranacionális szervezet hatásköreit és döntéshozatali kompetenciáját elfogadják és magukra nézve kötelezőnek ismerjék el. ${ }^{275}$ (Ezen a ponton válik aktuálissá ismét a német PSPP döntés: a Szövetségi Alkotmánybíróság - határozata szerint - tiszteletben tartja a szupranacionális szint döntési kompetenciáját, addig amíg az visszavezethető a tagállamok döntésére, ti. az Alapító Szerződések rendelkezéseire. ${ }^{276}$ ) A csatlakozás utáni, későbbi kényszer alapja tehát az eredeti önkéntes elhatározás. Ezen a ponton azonban felmerül a kérdés, hogy ezt az önkéntes döntést vajon mi minden befolyásolja, illetve

\footnotetext{
${ }^{269}$ Blutman-Chronowski 2007, p. 3.

${ }^{270}$ Vincze-Chrnowski 2018, pp. 22-25.

${ }^{271}$ Vö.: 11/70. Sz. ügy

${ }^{272}$ Vincze-Chronowski 2018, 22-24.

${ }^{273}$ Weiler 1991, pp. 2434-2436.

${ }^{274}$ Uo.

${ }^{275}$ Uo.

276 Részletesen lásd a döntés elemzéséről szóló fejezetet. Illetve megjegyzést érdemel, hogy álláspontom szerint ezzel az egy gondolattal összegezhető az ultra vires aktusok problémájának lényege.
} 
befolyásolta? Itt már csak utalni szeretnék azon korábbi gondolatra, amely szerint az európai integrációs folyamat a globalizálódó környezet szükségszerü következménye, amely bizonyos szempontból kényszerpályára állítja az európai nemzeteket. Ismételt kérdésként tehető fel azonban, hogy az az egység, amely a szupranacionális berendezkedésben ölt testet, vajon képes-e beváltani a hozzá füzött reményeket? Jelen értekezésnek nem célja megválaszolni ezeket a kérdéseket, azonban egy rövid kitérő erejéig szükségesnek érzem a megállapítást, miszerint a feltett kérdések álláspontom szerint visszatükröződnek a „szuverenista” és „,integrista” megközelítésekben is. Az előbbi megközelítést vallók feltehetően kevésbé hisznek a szupranacionális szint hatékonyságában és a felmerülő globális problémák megoldását a nemzeti szinten látják biztosítottnak a szupranacionális szint támogatásával, míg az utóbbi megközelítést támogatók az ellenkező álláspontot képviselik. Jelen sorok szerzőjeként nem helyezkedem egyik álláspontra sem. Nézetem szerint a cél az európai nemzetek természetének megfelelö lehetö leghatékonyabb olyan rendszer kiépítése és fenntartása, amely képes kiállni a globalizációs kihívások próbáját az Európai Unió alapvető célja, a „,békés, közös jövő” építése mellett. Egy ilyen rendszerben - ahogyan azt napjainkban látjuk - azonban nem csak funkcionális, jogi kihívások, hanem társadalmi, értékrendi konfliktusok is kódolva vannak, ezért tartom az alkotmányos identitás koncepcióját kiemelten fontos kutatási területnek.

Folytatva a gondolatmenetet, a fenti anomáliák köré épült ki tehát a szuverén európai nemzetek és népek akaratából az európai együttmüködés, az Európai Unió és jött létre a szupranacionális tér, amelynek müködési mechanizmusát nevesíthetjük a többszintü alkotmányosság rendszereként, középpontban a szuverenitástranszfer intézményével. Ez a koncepció azonban eredetileg azért született, hogy meghatározza a specifikus európai alkotmányos struktúrát és különösen a kapcsolatot a nemzeti alkotmányjogok és az európai jog között. ${ }^{277}$ A többszintű alkotmányosság rendszerében az európai nemzetek, bár kétségtelenül müködőképes rendszert hoztak létre - amelynek operatív megvalósulása a többszintü kormányzás ${ }^{278}$-, az Uniót belülről feszíti egy alkotmányos feszültség: a fentebb ismertetett anomália (vagy alkotmányos paradoxon) kivetülése, amely végső soron az integráció destabilizálódásának veszélyét hordozza magában.

\footnotetext{
277 Pernice 2006, p. 13.

${ }^{278}$ Bővebben lásd: Kaiser 2019, pp. 51-60.
} 
A tagállami alkotmányok és az európai jog viszonya számos nemzeti alkotmánybírósági határozatban megjelenik és szinte az integráció fennállása óta születnek az alkotmányértelmező testületek olyan határozatai, amelyek fenntartásokat jelenítenek meg az uniós jog alkalmazásával szemben. ${ }^{279}$ Vagyis a fennálló anomáliát, amely köré az integráció épült, az EUB igyekszik egyoldalú szemlélettel, az uniós jog tagállami alkotmányok feletti szupremáciájával rendezni (amely hozzájárul és végül elvezet a lopakodó föderalizmus jelenségéhe ${ }^{280}$ ), míg a tagállami alkotmánybíróságok, mint a nemzeti alkotmányok legföbb örei, folyamatos kísérleteket tesznek önazonosságuk európai tagállamkénti meghatározására az EUB joggyakorlatának tiszteletben tartásával. Ugyanakkor a tagállami szuverenitás és alkotmányos rendelkezések egyidejü védelmével, Anne Levade szavaival élve, a tagállami alkotmányértelmezők megpróbálják összeegyeztetni az összeegyeztethetetlent. ${ }^{281}$

Megjegyzendő, hogy az uniós jog és a tagállami alkotmányos rendelkezések összeütközése nem csak államelméleti - szuverenitás - kérdés, de felveti az Európai Unió Bíróságának és a tagállami alkotmányértelmezők „hatásköri” összeütközésének kérdését is, hiszen míg az uniós jog autentikus értelmezője az Európai Unió Bírósága, addig a tagállami nemzeti alkotmányok erga omnes hatályú autentikus értelmezői a tagállami alkotmánybíróságok és legfelsőbb bíróságok. ${ }^{282}$ Ennek az összeütközésnek vált gyújtópontjává a Német Szövetségi Alkotmánybíróság már hivatkozott és a későbbiek során részletesen vizsgált PSPP döntése. Látszólag a döntésben a Német Szövetségi Alkotmánybíróság nem tartotta tiszteletben az EUB határozatát. Ennek oka azonban nem az uniós jog semmibevétele volt, hanem egy uniós szerv gyakorlatának a szerződéssel összeegyeztethetetlen jellege, amelyet az EUB megerősített. Vagyis a német testület az ultra vires jellegre tekintettel mellőzte az uniós bíróság döntésének alkalmazását.

Tény azonban, hogy a PSPP döntésig mind az integrációs oldal, mind a tagállamok pusztán elvi jelentőségü deklarációkkal igyekeztek megjeleníteni az általuk követendőnek ítélt irányvonalat, hiszen, mivel a fent megjelenített anomália főszabály szerint nem oldható fel e testületek eszközeivel annak politikai jellege miatt, a kérdés

\footnotetext{
${ }^{279}$ Különösen német AB: pl. Solange döntések, ultra vires teszt, stb.

${ }^{280}$ Sulyok 2015, pp. 29-30., illetve vö.: Deli 2019, pp. 7-13.

${ }^{281}$ Levade 2016, p. 70.

${ }^{282}$ Vö: Szakály 2015, pp. 34-35, Rychetsky 2017
} 
rendezésére egyetlen eszközként ezidáig e testületek az európai alkotmányos párbeszédet ${ }^{283}$ alkalmazzák, ügyelve arra, hogy a párbeszéd során soha ne kerüljön sor az összeegyeztethetetlen összeegyeztetésének pillanatára. Ebben a tendenciában jelent feltehetően gyökeres változást a német testület döntése, amely - ezidáig egyedülálló módon - kinyilvánította egy az EUB által hozott döntésről annak alkalmazhatatlanságát. Fontos azonban hangsúlyozni, hogy a PSPP döntés középpontjában egy speciális elem, az ultra vires aktus áll.

A fentiek szerint az uniós jogrend és a tagállami alkotmányok kapcsolatának egy speciális részterületét képezi tehát a tagállami alkotmánybíróságok határozatainak funkciója, illetve azok viszonya az uniós joghoz. A román Legfelsőbb Semmítő- és Ítélőszék által az EUB-hez 2019. május 6-án benyújtott előzetes döntéshozatali eljárásban (C-357/19. sz. ügy), az alkotmánybíróság gyakorlatilag kényszerpályára állította az EUB-t a tagállami alkotmánybíróságok szerepének uniós felfogását illetően. A tagállami alkotmánybíróság az alábbi kérdésben kérte a testület állásfoglalását: „Úgy kell-e értelmezni az uniós jog elsőbbségét, hogy az lehetővé teszi, hogy a nemzeti bíróság mellözze az alkotmánybiróság olyan határozatának az alkalmazását, amely határozatot az alkotmánybíróság alkotmányossági jogvitával kapcsolatos ügyben hozott, és amely a nemzeti jog értelmében kötelezö erejü?" 284

Úgy vélem, az alkotmányos identitás, mint az alkotmányos rendszerrel együtt járó, az alkotmányos rendszer egyediségét megtestesítő - és az unió által tiszteletben tartott minőség az európai tagállamok számára ennek az anomáliának a kezelésére - ha nem is feloldására - nyújthat eszközt mind a tagállamok, mind az integráció irányából (kvázi hidat képezve). Mivel azonban a fent ismertetett anomália genezise az állami - nemzeti szuverenitás oszthatatlansága és a nemzetekfelettiség - és ebböl fakadóan nemzeti alkotmányok és az európai jogrend viszonya -, a jelenség megértéséhez szükséges egyúttal a szuverenitás elméletének vizsgálata is. ${ }^{285}$

\footnotetext{
283 22/2016. (XII. 5.) AB határozat, AB 2016, 1418, 33- 34. pont, 45-46. pont, 76. pont. Az alkotmányos párbeszédről bővebben lásd: Drinóczi 2017a, pp. 86-161, illetve az abban foglaltakat és az alkotmányos párbeszéd koncepcióját egy másik megközelítésböl: Stumpf 2018

${ }^{284}$ Az ügyben jelen értekezés kéziratának lezárásakor még nem született döntés.

285 Jelen értekezés keretei között a szuverenitás természetének, különböző elméleteinek, illetve a szuverenitással szemben támasztott globalizációs követelmények (nehézségek) vizsgálata, csak az alkotmányos identitás értelmezéséhez a jelen értekezésben alkalmazott megközelítésekből szükséges mértékig képezi tárgyát. A szuverenitás és a globalizálódó nemzetközi jog, illetve a szuverenitás európai jogrendben betöltött szerepéről önálló értekezések készültek és készülnek vélhetően a jövőben is, illetve a
} 
„Az alkotmányozás dilemmái” c. könyvében Trócsányi a szuverenitás kérdését - jogi szempontból - akként foglalja össze, hogy egy adott állam akkor szuverén, ha rendelkezik területtel, a területhez köthető lakossággal és főhatalommal, valamint ha külső kapcsolataiban - ti. egy közösség tagjaival való konfrontációiban - önállóan tud cselekedni és más országok elismerik önállóként. ${ }^{286}$ Trócsányi rögzíti azonban azt is, hogy a szuverenitás nem lehet abszolút fogalom, amely állítás alátámasztására a föderatív államberendezkedéseket, illetve a szupranacionális szerveződéshez való tartozást hívja fel. ${ }^{287}$ Chronowski az állami szuverenitást - az európai integrációval összefüggésben -, mint az állam főhatalmának jogi kategóriákkal történő meghatározását definiálja, majd kifejti, hogy „,a szuverén állam főhatalma oszthatatlan, de az államhatalom gyakorlása megosztható és megosztandó."288 Trócsányi azonban az európai integráción túllépve, a szuverenitás kapcsán másfajta befolyásoló tényezőkre is kitér a jelenkori nemzetközi viszonyrendszerben. Mint arra rávilágít, napjainkban az állami föhatalom rendelkezési jogát már nemcsak a többi állammal szemben vállalt nemzetközi szerződéses kötelezettségek vagy föderális, szupranacionális tömörülések, hanem a globális nemzetközi szervezetek is képesek befolyásolni. Trócsányi példaként idézi az államok pénzügyi eladósodottsága nyomán, a nemzetközi pénzügyi szervezetek nemzeti parlamentek döntéseit befolyásoló szerepét is. ${ }^{289}$

Trócsányi ezen gondolatai napjainkban egy különösen aktuális kérdést vetnek fel (amelynek megválaszolása már nem tárgya jelen értekezésnek, azonban nem volna helyén váló mellőzni a gondolat rögzítését): az Európai Bizottság által előkészített Next Generation EU program ${ }^{290}$ lényegében egy, a COVID-19 járvány által okozott gazdasági károk enyhítésére megalkotott integrációs gazdaságélénkítő eszköz, amelynek finanszírozásához azonban a Bizottság az EU nevében kötvényeket fog kibocsátani a pénzügyi piacokon, amelyek futamideje 3-30 év. A Next Generation EU megvalósításának technikai és gazdasági háttere nem tartozik jelen értekezés tematikus

szuverenitás és az alkotmányos identitás közötti kapcsolat szintén önálló kutatás tárgyát képezheti. A teljesség igénye nélkül: Takács 2015, Drinóczi 2017a, pp. 86-162, Kruzslicz 2019.

286 Trócsányi $2014 \mathrm{a}$, p. 21.

287 Trócsányi 2014a, pp. 22-23., Trócsányi 2019, pp. 51-53.

${ }^{288}$ Chronowski 2005, p. 48.

289 Trócsányi 2014a, p. 23. Trócsányival közel azonos gondolatokat fogalmaz meg Habermas már idézett munkájában, azonban több mint harminc évvel (!) korábban. Vö: Habermas 1994, pp. 164-165.

${ }^{290} \mathrm{https}$ ://ec.europa.eu/info/live-work-travel-eu/health/coronavirus-response/recovery-plan-europe_hu 
kereteihez, azonban Trócsányi fent idézett gondolatai nyomán felmerül a kérdés, hogy amennyiben elfogadjuk, hogy a gazdasági és pénzügyi megfontolások alapvetően meghatározzák a nemzeti parlamentek szuverenitásból fakadó döntéseit, úgy vajon milyen hatást gyakorol majd a szupranacionális szerveződés hitelfelvétele ugyanezekre a döntéshozó testületekre, sőt esetleg kényszerpályára állítja-e a döntéshozókat. 


\subsection{Szuverenitás a többszintü alkotmányosság rendszerében}

Az Európai Unió és a tagállamok viszonyának vizsgálata során az egyik alapvető kérdés a szuverenitás ${ }^{291}$ hordozójának meghatározása, ${ }^{292}$ hiszen a szuverenitás a forrása az integráció államelméleti, politikatudományi és alkotmányjogi megítélésének. ${ }^{293}$ Mikor az alkotmányos identitás fogalmát kívánják definiálni és megérteni, a tagállami alkotmányértelmezők, de még a jogtudomány képviselői is igyekeznek az alkotmányjog keretei között maradni és ennek határain belül meghatározni az egyes aspektusokat. Az alkotmányértelmezők esetén ez nem is történhet másként, hiszen funkciójuk szerint erga omnes hatállyal az alkotmányt hivatottak értelmezni, egyszersmind őrizni. A jogtudományi elemzés során azonban érdemes az alkotmányos identitás szemszögéből a szuverenitás interdiszciplináris vizsgálata is: a politikatudományi, államelméleti kitekintés. Tekintettel különösen arra, hogy az európai integráció elsősorban politikai szerveződés. ${ }^{294}$

A szupranacionális jelleg intézményesülése az átruházott hatáskörökön keresztül valósul meg, amelynek elméleti megfelelője az átengedett szuverenitás, a „,szuverenitástranszfer.” Az alkotmányos identitás uniós értelmezése - elválasztva az alapvető állami funkcióktól - feltehetően a tagállami alkotmányos berendezkedések olyan immanens elemeire alkalmazható, amelyeknek érinthetetlennek kell lenniük az uniós jogrend számára és amely egyúttal azt is jelenti, hogy azok az átengedett hatáskörök korlátját képezik. A szuverenitástranszfer intézménye azonban nem pusztán hatásköri és eljárási szabályok halmaza. Természetesen ezekben a hatásköri, tételes jogi szabályokban ölt testet, azonban érvényesülése függ az integráció államelméleti felfogásától. Nevezetesen: amennyiben úgy közelítjük meg az integrációt, mint amely az államszövetségi jellegből a szövetségi állam felé halad, ${ }^{295}$ úgy a szuverenitástranszfer egy ideiglenes intézmény, amely az integráció végső állapotának eléréséig biztosítja a tagállamok és az integráció közötti viszony stabilitását, egyszersmind lehetővé teszi a föderalizálódás folyamatát.

\footnotetext{
291 Vö.: Fassbender 2018, pp. 1207-12014.

292 Vö.: Bihari 2014, illetve: Maris-Sklias 2016

${ }^{293}$ Vincze-Chronowski 2018, pp. 20-27.

${ }^{294}$ Vö.: Fossum 2017

295 Körösényi 2004, pp. 149-154.
} 
Amennyiben azonban az integrációt, mint egy teljesen új államelméleti kategóriát fogjuk fel és nem egy, a konföderáció és a föderáció közötti skálán kívánjuk elhelyezni, úgy a szuverenitástranszfer és az alkotmányos identitás ennek az új entitásnak egy meghatározó tulajdonságaként fogható fel, amelynek kiforratlansága magának az entitás kiforratlanságának a következménye. Ebben az esetben a megoldandó probléma a tagállamok és az integráció közötti alapvető hatalmi - ti. alkotmányos - viszonyok kialakítása, amely azonban már nem (jog)technikai, hanem politikai döntés. Az alkotmányos identitás részben a tagállami alkotmányos berendezkedések egyedi, immanens elemeit tekintve alkalmas jogtechnikai eszköz lehet a kérdés megválaszolására, hogy mely pontig terjed az integráció „hatalma” és mely ponttól kezdődik a tagállami „hatalom. ${ }^{296}$ Ez indokolja az alkotmányértelmező testületek, illetve magának az EUB-nek a visszafogott és óvatos értelmezési gyakorlatát, kvázi „tapogatózását” a témában.

Hipotetikusan megközelítve a kérdést, ha az alkotmányértelmező testületek integrációszerte egységesen meghatároznák az alkotmányos identitást, vagyis az integráció és a tagállamok közötti határmezsgyét - akár az EUB-vel együttműködve akkor ebben a pillanatban az alkotmányértelmezők és az EUB politikai döntéshozatali jogkört vindikálnának maguknak ${ }^{297}$, hiszen ez olyan - politikai - jellegü döntés, amelyet kizárólag a tagállamok legföbb döntéshozói határozhatnak meg az alapító szerződések szintjén.

Az alkotmányos identitás körülhatárolása és a fogalmi rendszer megszilárdulása az integráción belül alkalmas jogtechnikai eszközt jelenthet a tagállami alkotmányos berendezések egyedi, immanens elemeinek védelmére, amelynek keretei az EUSZ (4). cikk rendelkezésein keresztül adottak is, azonban

(i) ehhez nem elegendőek az alkotmányértelmező testületek - létfontosságú deklaratív jellegü döntései, szükséges egy felsőbb szintü, politikai döntés, amelyben a tagállamok az alapító szerződések szintjén nyilvánítják ki akaratukat a tagállamok és az integráció közötti viszonyt illetően,

\footnotetext{
296 Az EUSZ 4. cikkének megszövegezésére tekintettel azonban nem alkalmazható az alapvető állami funkciók meghatározására és így hatásköri kérdésekben nem hívható fel az uniós joggal szemben.

297 A német PSPP döntés bizonyos tekintetben át is lépte ezt a határmezsgyét.
} 
(ii) szükséges az EUB és a tagállami alkotmányértelmezők közötti viszony meghatározása és végül

(iii) amíg az EUSZ 4. cikke az identitás-klauzulát az alapvető állami funkcióktól elkülönítetten tartalmazza, addig hatásköri összeütközések - és így az ultra vires aktusok - lásd PSPP! - esetén az alkotmányos identitás nem hívható fel az uniós joggal szemben.

A többszintű alkotmányosság rendszerében - e helyütt mellözve a mélységi vizsgálatot a szuverenitás értelmezéséhez el kell különítenünk a szuverenitás jogi és politikatudományi felfogását. ${ }^{298}$ Jogi értelemben a szuverenitás a már fentebb idézettek szerint a terület, népesség, főhatalom együttesével írható le legegyszerübben, kiegészülve a szuverenitás külső oldalával, vagyis a nemzetközi elfogadottsággal. Politikatudományi szempontból azonban a szuverenitás a végső politikai döntés meghozatalának jogaként fogható fel, amely minden esetben politikai tartalmú és nem jogi döntés. ${ }^{299}$ Ahogyan Körösényi írja, ,, az alkotmányos jogállam nem természettől fogva adott, hanem egyrészt politikai döntés, illetve politikai döntést jelentő alkotmányozás eredménye, másrészt fennmaradása nem automatikus, potenciálisan politikai védelemre szorul belsö és külsö fenyegetésekkel szemben egyaránt. "300

A szuverenitás is hasonlóképpen fogható fel, amely Janus arcú intézmény: kereteit tekintve az alkotmányjog szabályaiba és követelményeibe foglalt, tartalmában azonban végső soron politikai döntések összessége, amelyekhez a föhatalom birtokosaként az államot megillető jogok és kötelezettségek társulnak, amelyek azonban korlátozottak az állami önkorlátozás révén az alkotmány és nemzetközi egyezmények által. ${ }^{301}$

Ha ebből az irányból közelítjük meg a szuverenitás, az integráció és az alkotmányos identitás viszonyát, akkor a jövőre nézve három lehetséges irányvonal körvonalazható: ${ }^{302}$

\footnotetext{
298 Vö.: Bihari-Pokol 2013, pp. 352-362., illetve: Rigó Anett: Szuverenitás és legitimitás, a szuverén államtól a globális kormányzásig? URL: http://dfk-online.sze.hu/images/JÁP/2009/1/rigó.pdf

${ }^{299}$ Idézi Körösényi Schmittre és Böckenfördere utalással: Körösényi 2004, p. 158.

${ }^{300}$ Uo.

${ }^{301}$ Bihari-Pokol 2013, 360.

${ }^{302}$ Vö.: Körösényi 2004, p.154.
} 
- A tagállami szuverenitás dominanciája erősebb a tagállamokat egymás irányába kényszerítő globalizációs hatásoknál, amely hosszú távon az integrációs folyamatok gyengülését eredményezi (vö. Coulomb-taszítás, fentebb).

- Az átengedett és fenntartott szuverenitás aránya folyamatosan az integráció irányába tolódik, hosszú távon a föderatív berendezkedés irányába mozdítva azt. Ebben az esetben az alkotmányos identitás szupranacionális térben megnövekedett jelentősége ideiglenesnek tekinthető és az egységesülés folyamata által életre hívott természetes feszültségekre adott válaszreakció megnyilvánulásaként fogható fel, hosszú távon azonban jelentősége csökken.

- Az integrációt, mint új politikai és államelméleti szerkezetet határozzuk meg, amelyben a hangsúly a szuverenitásból fakadó hatáskörök megosztásának egyensúlyán van az EUSZ-ben meghatározott elvek - egyenlőség, arányosság, szubszidiaritás - szerint. Ebben az esetben azonban a szuverenitás - jelenleg ismert - felfogását hosszú távon felemészti az integráció és a tagállamok egyensúlyra törekvő viszonya - tekintettel annak merev, a tagállami dominanciát az egyensúllyal szemben megtestesítő jellegére -, míg az alkotmányos identitás az integráció túlhatalmának fékezésére hivatott elvként érvényesül.

Jelen pillanatban egyik irányról sem jelenthető ki bizonyossággal, hogy az integráció jövője ezen az úton haladna, azonban a PSPP döntés kiváló példája annak, hogy a mozdulatlanság az integrációs folyamatban nem tartható fenn hosszú távon, így a fenti irányok valamelyikébe történő elsodródás csak idő kérdése. 


\section{3. Ép testben ép lélek: Alkotmány - szuverenitás - identitás}

Az európai integráció által teremtett szupranacionális tér speciális környezetet jelent tehát a tagállamok alkotmányos rendszerei és az európai integráció által életre hívott jogi környezet összehangolását illetően, amely környezetben az alkotmányos identitás fogalmát is e specifikus környezet sajátosságainak megfelelően szükséges meghatározni (és így adott esetben az angolszász felfogáshoz képest újraértelmezni azt). Különösen a tagállamok és az integráció közötti viszony - így a szuverenitástranszfer meghatározását illetően annak érdekében, hogy a fogalom alkalmassá válhasson a tagállamok és az integráció közötti alkotmányos viszony meghatározására és az alkotmányos paradoxon kezelésére.

Összegzésképpen elmondható, hogy a nemzetközi közösség által meghatározott általánosan alkalmazott elvek és követelmények - mintegy a globalizáció hatásaként az alkotmányos rendszerekre - mostanra relatívvá teszik a szuverén államhatalom szabadságát az alkotmányos berendezkedés formálását illetően. A nemzetközi tendenciák, standardok és kötelezettségek leképződnek - és le is kell képződniük - az egyes szuverén alkotmányos rendszerekben és így törvényszerűen visszatükröződnek az egyes nemzeti alkotmányokban, amelyek ezáltal nemzetközileg meghatározottakká válnak. Ebben a viszonyrendszerben egy speciális, szorosabban együttmüködő régiót jelent az európai integráció: az együttmüködés egy, a tagállamok akaratából létrejövő olyan önálló, szupranacionális jogrendszer, amely szükségszerüen meghatározza az azt életre hívó tagállamok alkotmányos berendezkedését. A többszintü alkotmányosság jelenti tehát azt a keretet, amelyben a tagállamok és az integráció viszonyát meg kell határoznunk, vagyis jelenti az európai integrációban azt a koordináta rendszert, amelyben és amelyre tekintettel az alkotmányos identitás fogalmának európai értelmezését definiálnunk kell.

Az alkotmányos identitás koncepciója körül - hasonlóan az integráció és a tagállamok viszonyához - számos vita és nyitott kérdés merül fel. A végső kérdés azonban minden esetben az uniós jogrend és a nemzeti alkotmányok kapcsolata lesz. Hogy ez milyen irányban, milyen mértékben és az integráció mely szereplőinek hatására változik, az jelenleg kérdéses. Jelen pillanatban, mint a nemzeti alkotmányok autentikus értelmezői, 
az alkotmánybíróságok ${ }^{303}$, illetve, mint az uniós jogrend autentikus értelmezője az Európai Unió Bíróságának gyakorlata meghatározó. ${ }^{304}$ A bírói joggyakorlat - mind tagállami, mind EUB - azonban a kérdést csak kezelni képes, feloldani nem. Ez arra vezethető vissza, hogy az alkotmányos identitás felértékelődését életre hívó anomália a tagállamok és integráció között az Unió és a tagállami alkotmányok kapcsolatának meghatározatlanságából fakad, ezért végleges jelleggel csak politikai szinten, a kapcsolat alapító szerződésekbe foglalásával oldható fel. Ilyen, konszenzuson alapuló döntés hiányában (amely vélhetően az integrációs folyamat egy további szintjét jelentené a jövőben) azonban a tagállami alkotmánybíróságok és az EUB gyakorlatának közelítése konvergenciája ${ }^{305}$ - mutatkozik alkalmazható alternatívának ${ }^{306}$, amelyet e bírói fórumok az alkotmányos párbeszéden ${ }^{307}$ keresztül valósítanak meg a korábban már érintőlegesen tárgyaltak szerint.

A nemzeti alkotmányok értéktartalmát, illetve az integráció értékközösség jellegét illetően a tagállamoknak az integrációhoz történő csatlakozásból fakadó kötelességük ugyan, hogy el kell fogadniuk annak alapvető értékeit, ugyanakkor az integráció kötelezettsége pedig az, hogy figyelembe vegye és tiszteletben tartsa a tagállamok egyediségéből származó differentia specificáit. Visszavezethető mindez az alkotmánnyal szemben támasztott azon követelményre, miszerint meg kell, hogy feleljen az életre hívó közösség természetének: a nemzeti alkotmányok éppen annyira lehetnek hasonlóak, vagy különbözőek, mint az azokat életre hívó alkotmányos közösségek, vagyis az európai népek. Ez egyúttal azt is jelenti, hogy mivel Európában nem beszélhetünk egységes népröl, csak nemzetek közösségéről ${ }^{308}$, ezért az egységes értékrend kialakítása is korlátozott és a nemzetek közötti hasonlóságok és különbözőségek által meghatározott. Mindez leképeződik a tagállami alkotmányok rendelkezéseiben, illetve a tagállamok reakcióiban az alkotmányos rendelkezéseket érintő integrációs normákat illetően. Egyúttal visszatükröződik a teljes szupranacionális jogrendben és elvezet a kérdésig,

\footnotetext{
${ }^{303}$ Vö.: Drinóczi 2018a, pp. 7-13.

${ }^{304}$ Vö.: Drinóczi 2016c, pp. 55-58.

305 Vö.: Sulyok 2017, pp.146-150.

306 Vö.: Orbán 2018, p. 8.

307 Vö.: 22/2016. (XII. 5.) AB határozat, $\mathrm{AB}$ 2016, 1418, 33- 34. pont, 45-46. pont, 76. pont. Az alkotmányos párbeszédröl bővebben lásd: Drinóczi 2017a, pp. 86-161.

${ }^{308}$ Paczolay 2000, pp. 84-88.
} 
miszerint lehet-e az integrációnak alkotmánya és beszélhetünk-e európai alkotmányos identitásról? ${ }^{309}$

\subsection{Az alkotmányos identitás belső oldala, mint örökkévalósági klauzulák?}

Az alkotmányos identitás gyakorlati értelmezése Európában a Német Szövetségi Alkotmánybíróság már hivatkozott Solange döntéseivel vette kezdetét. Eszerint a német alkotmányos identitás forrása az Alaptörvény 79. cikk (3) bekezdésében foglalt örökkévalósági ${ }^{310}$ klauzula. ${ }^{311}$ Később, hasonlóan a német gyakorlathoz, azon tagállamok alkotmánybíróságai, amelyek explicit, vagy implicit ${ }^{312}$ örökkévalósági klauzulát alkalmaznak alkotmányukban, az alkotmányos identitás forrásaként az örökkévalósági klauzulával (is) védett attribútumokat határozták meg. ${ }^{313}$ Ez a trend pedig egyértelmüen felveti a kapcsolat lehetőségét az alkotmányos identitás és az örökkévalósági klauzulák között. ${ }^{314}$

\footnotetext{
${ }^{309} \mathrm{Vö.:} \mathrm{jelen} \mathrm{értekezés} \mathrm{4.2.} \mathrm{fejezet.}$

${ }^{310}$ Vö.: Csink - Fröhlich 2012, pp. 57-59.

311 Vö: BVerfGE 37, 271 - Solange I., BVerfGE 73, 339 -Solange II., illetve Müller 2016, pp. 73-78.

${ }^{312}$ Szakály-Tribl, 2018, pp. 16-20.

313 Vö.: Szakály-Tribl 2018, p. 11.

${ }^{314}$ Vö.: Szakály-Tribl 2018, Levade 2016, pp. 68-72.
} 


\subsubsection{Egy kérdőíves vizsgálat eredményei}

Az örökkévalósági klauzulák és az alkotmányos identitás közötti kapcsolat kimutatása érdekében 2018-ban társkutatóval együttmüködésben, az Alkotmánybíróságon keresztül kérdőívet küldtünk az integráció valamennyi tagállamának alkotmányértelmező testületeihez, amelyben e testületek vonatkozó gyakorlatát, illetve az azokban megjelenő alkotmányértelmezői álláspontot vizsgáltuk. A kérdőív három részre osztható az alábbiak szerint:

(i) Örökkévalósági klauzulára vonatkozó kérdések: Alkalmaz-e explicit örökkévalósági klauzulát a tagállam, illetve ennek hiányában az alkotmányértelmező gyakorlatából kimutatható-e implicit örökkévalósági klauzula;

(ii) Az alkotmányértelmező gyakorlatában felfedezhető-e utalás az alkotmányos identitás koncepciójára, illetve amennyiben igen és létezik a tagállamban valamilyen formában örökkévalósági klauzula, vagy ahhoz hasonló rendelkezés, úgy kimutatható-e kapcsolat a két fogalom között;

(iii) A kérdőív harmadik része az alkotmányi és az uniós jog összeütközése esetére kialakított alkotmányértelmezői gyakorlatra vonatkozott.

Az alkotmányértelmező testületek megkeresésének célja a vonatkozó joggyakorlat összegyüjtése volt. A kiküldött kérdöív teljes szövegét az 1. sz. melléklet tartalmazza. A megkeresésre hazánkon ${ }^{315}$ túl nyolc tagállami alkotmányértelmező testület (Ausztria, Csehország, Horvátország, Lettország, Málta, Németország, Szlovákia, Szlovénia) válaszolt. A megküldött válaszok alapján készített összesítő táblázatot a 2. sz. melléklet tartalmazza. A mindezek alapján rendelkezésre álló gyakorlat szerint:

Ausztria alkotmányos identitása az Alkotmánytörvény 1. és 2. cikkén alapul és magában foglalja a demokratikus joggyakorlás követelményét, a jogállamiságot, a köztársasági államformát, illetve a föderatív állam-berendezkedést. Az osztrák alkotmányos berendezkedés nem alkalmaz explicit örökkévalósági klauzulát, azonban az

${ }^{315}$ Hazánk alkotmányos identitásra vonatkozó gyakorlatával az értekezés önálló fejezetében foglalkozom, így annak bemutatását e helyen mellőzöm. 
Alkotmánytörvény 44. cikk (3) bekezdése és az Osztrák Alkotmánybíróság állandó gyakorlata alapján az Alkotmánytörvény 1. és 2. cikkében foglaltak megváltoztatásához az Alkotmánytörvény teljes revíziójára van szükség, amely így a 44. cikk alapján népszavazáshoz kötött (implicit, „kvázi” örökkévalósági klauzula).

Csehország alkotmányának 9. cikke a jogállamiság által meghatározott alkotmányos berendezkedést explicit formában is örökkévalósági klauzulaként tartalmazza. A Cseh Alkotmánybíróság Lisszabon-döntésében (PL. ÚS 19/08 sz. döntés) az alkotmány 9. cikkére hivatkozással vezette le azon álláspontját, amely szerint a nemzetközi szervezetre történő hatáskörátruházás nem sértheti a köztársaság lényegét. A Lisszabon-döntésben az alkotmányos identitásra vonatkozó utalást nem alkalmazott a testület, azonban a „,szlovák nyugdíjügyben" (ÚS 5/12 sz. döntés) igen. Ebben a döntésében a Cseh Alkotmánybíróság visszautalt korábbi Lisszabon-döntésére, lényegében párhuzamot vonva (pontosabban közös metszetet kialakítva) $)^{316}$ az alkotmányos identitás és az örökkévalósági klauzula között. ${ }^{317}$

A horvát alkotmány nem alkalmaz explicit örökkévalósági klauzulát, azonban az alkotmányértelmező implicit módon az U-VIIR-164/2014 sz. ügyben az oszthatatlan, unitárius, demokratikus alapokon nyugvó állami berendezkedést, a népszuverenitást, a szabadságot és jogegyenlöséget, a nemzetiségek és nemek egyenlőségét, a béke tiszteletét, a társadalmi igazságosságot, az alapvető jogok tiszteletét, a tulajdonhoz füződő jog szentségét, a fenntartható környezet megóvását, illetve a jogállamiság és pluralizmus elvét kvázi örökkévalósági klauzulának tekintette. Az alkotmánybíróság több határozatában foglalkozott az alkotmányos identitás kérdésével, ${ }^{318}$ amely gyakorlat alapján az alapvető alkotmányos elvek és értékek, a horvát állam strukturális felépítése,

\footnotetext{
316 A testület a Cseh Köztársaság alkotmányos identitását a Szlovák Köztársasággal közös múltból eredezteti. Vö.: ÚS 5/12 sz. döntés VII. fejezetében: “...the Constitutional Court in its statement expressed the expectation that, at least in order to preserve the appearance of objectivity, the ECJ would familiarize itself with the arguments that respected the case law of the Constitutional Court and the constitutional identity of the Czech Republic, which it draws from the common constitutional tradition with the Slovak Republic, that is from the over seventy years of the common state and its peaceful dissolution, i.e. from a completely idiosyncratic and historically created situation that has no parallel in Europe."

A határozat teljes szövege elérhetö angol nyelven: https://www.usoud.cz/fileadmin/user_upload/ustavni_soud_www/Decisions/pdf/Pl\%20US\%205-12.pdf

317 A cseh gyakorlat részletes elemzését bővebben lásd: Drinóczi 2016b, pp. 10-11.

${ }^{318}$ U-IP-3820/2009 sz. döntés, U-IP-3826/2009 sz. döntés, U-I-3597/2010 sz. döntés, U-VIIR-5292/2013 sz. döntés, U-VIIR-1159/2015 sz. döntés, U-II-6111/2013 sz. döntés
} 
a szociális állam eszméje, a nemzeti kisebbségek védelme, illetve a demokratikus hatalomgyakorlás említhető e körben.

A lett alkotmány nem tartalmaz explicit örökkévalósági klauzulát, azonban a Lett Alkotmánybíróság kiterjedt gyakorlattal rendelkezik mind az implicit örökkévalósági klauzulaként értelmezett alkotmányi rendelkezések, mind az alkotmányos identitás vonatkozásában. ${ }^{319} \mathrm{Az}$ alkotmányértelmező „Lettország alkotmányának (Satversme) magjaként” tekint az alkotmány 1-4. cikkeire, amely alapján implicit, „kvázi” örökkévalósági klauzulának tekinti a független és demokratikus köztársaságra vonatkozó rendelkezéseket, a népszuverenitást, az államterület védelmét, a lett nyelv és a nemzeti zászló tiszteletét, illetve a parlamenti választások alapvető szabályait. Az alkotmányértelmező 2015-01-01-i döntésének 15.2. pontja ${ }^{320}$, illetve 2017-01-01-i döntésének 16. pontja $^{321}$ alapján az alkotmányos identitás körébe vont értékekként azonosítja a szuverenitást, a nemzeti függetlenséget, Lettország területi integritását, a demokratikus hatalomgyakorlás elvét, a lett nyelv tiszteletét, az alapvető emberi és keresztény értékeket, illetve a lett nemzeti zászló és a nemzeti jelképek tiszteletét. ${ }^{322}$

A máltai alkotmányos berendezkedés nem alkalmaz sem az alkotmányban szereplő explicit, sem az alkotmányértelmező gyakorlatában fellelhető implicit örökkévalósági klauzulát, illetve az alkotmánybírósági gyakorlat nem alkalmazza gyakorlatában az alkotmányos identitás koncepcióját. A kiküldött kérdőívre visszaérkező válaszok alapján azonban - hipotetikusan - Málta Alkotmányának 66. cikke (ti. az alkotmánymódosításra, illetve a parlament feloszlatására vonatkozó szabályok) kvázi örökkévalósági klauzulaként funkcionálhat. Az alkotmányos identitás forrásául az alkotmány első

\footnotetext{
${ }^{319}$ A lett alkotmányos identitásról készített összefoglalót lásd: Ineta Ziemele: Role of the Constitutional Courts in Upholding and Applying the Constitutional Principles: the Case of Latvia http://www.satv.tiesa.gov.lv/en/articles/role-of-the-constitutional-courts-in-upholding-and-applying-theconstitutional-principles-the-case-of-latvia/ A lett Alkotmányügyi Bizottság által, az alkotmányos identitásról 2012-ben készített átfogó vizsgálatot lásd lett nyelven: http://blogi.lu.lv/tzpi/files/2017/03/17092012_Viedoklis_2.pdf A vizsgálat angol nyelvü összefoglalóját a 3. sz. melléklet tartalmazza.

320 "The Latvian national flag as the symbol of the state is also an integral element in the constitutional and international identity of the Latvian state."

321 "The Latvian language as the official language is an indispensable part of the constitutional identity of the state of Latvia. The Latvian language as the official language bestows upon the state of Latvia a particular - and exactly Latvian - national cultural identity."

${ }^{322}$ Megjegyzendő, hogy az alkotmánybíróság az alkotmányos identitás alkotmányi forrásaként a Satversme 2014-es módosításakor a szöveghez füzött preambulumot azonosítja. A lett alkotmány teljes szövege angol nyelven elérhetö: http://www.satv.tiesa.gov.lv/en/2016/02/04/the-constitution-of-the-republic-of-latvia/
} 
fejezete (demokratikus köztársaság, területi integritás, nemzeti vallás, a nemzeti nyelv, a zászló és a himnusz tisztelete), második fejezete (alapvető alkotmányos elvek) és negyedik fejezete (alapvető jogok és szabadságok) szolgálhatnak.

A német alkotmánybíróság gyakorlatának elemzését számos hazai és nemzetközi vizsgálat elvégezte, így annak részletes bemutatásától eltekintek. ${ }^{323}$ A következetes német gyakorlat az alkotmányos identitás forrásaként a Német Alaptörvény 79. cikk (3) bekezdésében foglalt explicit örökkévalósági klauzulát jelöli meg, így különösen az emberi méltóság védelmét, a demokratikus hatalomgyakorlást, a jogállamiságot, a szociális államot, illetve a föderális berendezkedést. A német alkotmányértelmező nem tért el az alkotmányos identitásra vonatkozó állandó gyakorlatától a PSPP döntésben sem, ennek részletes ismertetését azonban a határozat vizsgálatáról szóló fejezetben végzem el.

Szlovákia alkotmánya nem tartalmaz explicit örökkévalósági klauzulát, azonban az alkotmánybíróság P1. ÚS 24/2014 és PL. ÚS /2017 sz. döntései alapján az alkotmány 1.1., 12.1. és 93.3. pontjaiban foglalt rendelkezések implicit örökkévalósági klauzulának tekintendők. Ezek alapján kiemelt védelem illeti meg: a szuverenitásra, a demokratikus hatalomgyakorlásra, a jogállamiságra, az alapvető jogok és szabadságok védelmére, illetve az állami költségvetés alapvető jogok érvényesülését érintő részeire vonatkozó rendelkezéseket. A Szlovák Alkotmánybíróság alkotmányos identitást alkalmazó II. ÚS 171/2005, III. ÚS 427/2012 és PL ÚS 7/2017 sz. döntései alapján a szlovák alkotmányos identitás körébe vonható az államiságot és szuverenitást kifejező és megtestesítő köztársasági elnök személye, a köztársasági államforma, a demokratikus hatalomgyakorlás, a jogállamiság, illetve az alapvető jogok és szabadságok védelme.

A megküldött kérdőív alapján Szlovénia alkotmányos berendezkedése nem alkalmazza sem az explicit, sem az implicit örökkévalósági klauzulák intézményét, az alkotmányértelmező pedig nem hivatkozott gyakorlatában az alkotmányos identitás koncepciójára.

${ }^{323}$ Vö.: Sulyok 2014, pp. 52-53., Polzin 2016, Drinóczi 2016b pp. 7-9. 
A hazánkkal együtt kilenc tagállam által megküldött összefoglaló értékelés alkotmánybíróságaik gyakorlatáról nem tekinthető reprezentatívnak és nem vonható le belőlük kizárólagos, valamennyi tagállamra vonatkozó következtetés. A vizsgálatunkban aktívan közreműködő tagállamok gyakorlata azonban alkalmas arra, hogy trendeket és tendenciákat határozzunk meg. Következtetéseink szerint, amelyeket az értekezésben foglaltak kapcsán is irányadónak tekintek, az örökkévalósági klauzula intézményét valamilyen formában (explicit vagy implicit) alkalmazó tagállamok alkotmányértelmező testületei párhuzamot vonnak az alkotmányos identitás és az örökkévalósági klauzulák tartalma között, azok részben, vagy egészben egymással átfedésben állnak. 


\subsubsection{Az örökkévalósági klauzulák és az alkotmányos identitás közötti kapcsolat}

Az alkotmányos identitás európai értelmezésében mérföldkövet jelentettek a Német Szövetségi Alkotmánybíróság Solange-döntései, míg Uniós oldalon a maastrichti, jelenleg a Lisszaboni Szerződésbe foglalt identitás-klauzula megjelenése óta formálódó gyakorlatot ${ }^{324}$ és tudományos álláspontokat szemlélve - a korábban kifejtettek szerint az alkotmányos identitás koncepciójának európai fejlődése olyan kísérletként értelmezhető, amely a tagállami alkotmányok rendelkezései és az uniós jog közötti viszony kiegyensúlyozására törekszik. ${ }^{325}$

Szükséges azonban kiemelni, hogy az identitásképzés modelljénél meghatározottak szerint, az alkotmányos identitás formálódása nem a szupranacionális környezet következménye: az alkotmányos identitás az alkotmányos alanyon belüli tényezők kölcsönhatásaként alakul ki, amely ezáltal formálja az alkotmányos berendezkedést. Az identitáselemek korlátozott változékonysága - amely visszavezethető az alkotmányos közösség természetének korlátozott változékonyságára ${ }^{326}$ - ezért azt eredményezi, hogy az egyes identitásjegyek az alkotmányos berendezkedés meghatározó attribútumaivá válnak. Ilyenek például a történeti alkotmány vívmányai Magyarországon, a laicitás Franciaországban, az emberi méltóság védelme és a föderális berendezkedés Németországban, stb. Ezek az - értéktartalommal bíró - attribútumok általában az alkotmányos berendezkedésen belül is megkülönböztetett védelemben részesülnek. A szupranacionális jogrendhez csatlakozással azonban ezeket - vagyis lényegében az alkotmányos identitást - egy, az alkotmányos berendezkedés szempontjából külső, nemzetek feletti közegben is védelemben kell részesíteni. Ebből adódóan tulajdonképpen az előbbi, alkotmányos berendezkedésen belüli védelem meghatározható az alkotmányos identitás belső, míg az alkotmányos berendezkedésen „felüli” védelem az alkotmányos identitás külső oldalaként is.

${ }^{324}$ Vö.: 22/2016. (XII. 5.) AB határozat, AB 2016, 1418, 32- 46. pont, Sulyok 2014, pp. 50-60., Drinóczi 2016b, pp. 2-15.

325 Vö.: Rychetsky 2017, pp. 95-98.

${ }^{326}$ Vö. Habermas alkotmányos patriotizmus elmélete. 
Az értekezés korábban tett megállapításai alapján az alkotmányos identitás a nemzeti alkotmányok egyes - értékhordozó - rendelkezésein keresztül manifesztálódik ${ }^{327}$, amely rendelkezések összessége az alkotmányos rendszer olyan karakterisztikáját jelenti, amely önmagában is védendő értékként determinálható, ${ }^{328}$ és amely az alkotmányos rendszer múltjából kifolyólag meghatározott. Az alkotmányjog tudománya azonban már ismer és alkalmaz egy, az alkotmányos identitás fenti aspektusához hasonló jogintézményt: az örökkévalósági klauzulákat.

Az örökkévalósági klauzulákba foglalt alkotmányi rendelkezések (értékek, alapelvek stb.) az alkotmányozó hatalom által érinthetetlennek minősítettek, csak új alkotmány elfogadásával lehetséges a változtatás ezen klauzulák tartalmán. Az örökkévalósági klauzulával védett rendelkezések tehát az alkotmányos rendszer olyan „alapvető szerkezetét”329 érintő értékhordozó és garanciális szabályok, amelyeket nem lehet megváltoztatni, csak és kizárólag alkotmányozással. Mindez azt is jelenti, hogy a fogalom egyik előkérdése az alkotmányozás és az alkotmánymódosítás fogalmának elválasztása: az örökkévalósági klauzulák alkalmazásához elengedhetetlenül szükséges az alkotmánymódosítás és az alkotmányozás külön eljárásként való kezelése, hiszen pont az adja meg az örökkévalósági klauzulák feladatát, hogy az alkotmány bizonyos rendelkezéseit védik az (adott esetben alkotmányellenes) alkotmánymódosítással szemben. ${ }^{330}$

Az Európai Unió számos tagállamának alkotmánya tartalmaz örökkévalósági klauzulát valamilyen formában. E szerint megkülönböztethetjük az ún. kifejezett vagy explicit örökkévalósági klauzulákat, amelyek kimondottan ilyen módon vannak meghatározva, vagyis maga az alkotmány szövege biztosítja ezt a rangot a rendelkezések számára. Az implicit klauzulák esetében ezzel szemben az alkotmányértelmező „olvasztja ki” az

\footnotetext{
${ }^{327}$ Azzal a megállapítással azonban, hogy az identitás kétségtelenül egy dinamikusabb és megfoghatatlanabb jelenség az alkotmányokban rögzített rendelkezések katalógusánál.

${ }^{328} \mathrm{Az}$ európai integrációban egyedülálló módon erre tesz kísérletet Magyarország Alaptörvényének 2018. június 20-án elfogadott 7. sz. módosítása, amelynek elemzésétől jelen tanulmány keretei között szintén eltekintek.

${ }^{329}$ Az alapvető szerkezet elméletet lásd: Roznai 2017, p. 44.

${ }^{330}$ Vö.: Szakály 2018, pp. 59-60.
} 
alkotmány szövegéböl a klauzulát, nincs benne konkrétan az alkotmány szövegében az örökkévalósági klauzula „rangja”. 331

Az alkotmányos identitás és az örökkévalósági klauzulák tehát egyaránt az alkotmányos rendszer (lisszaboni fordulattal: berendezkedés) egy meghatározó részének, pontosabban karakterisztikájának védelmét szolgálják. Látható egyúttal, hogy az örökkévalósági klauzulák által védendő tartalom megegyezik - vagy legalább is erösen konvergál - az alkotmányos identitás által védett attribútumokkal, amelyek az uniós jog viszonylatában egybeesnek az EUSZ 4. cikk értelmezési kérdéseivel, illetve az ezen attribútumok védelme iránti tagállami igénnyel. Az alkotmányos berendezkedés ezen immanens elemeinek védelemben részesítése az alkotmányos berendezkedésen belül tehát megvalósulhat az örökkévalósági klauzulák által, mint az alkotmányos identitás belső oldala, míg az alkotmányos berendezkedésen túli, szupranacionális dimenzióban a védelem igénye és az EUSZ 4. cikkének találkozása létrehozza az alkotmányos identitás megjelenésének és védelmének külső oldalát. Az alkotmányos identitás és az örökkévalósági klauzulák között ezért a fentiek szerint szoros kapcsolat feltételezhető, illetve mutatható ki: ${ }^{332}$ az alkotmányos rendszer karakterisztikájának, ugyanazon integráns részének védelmét szolgálják.

A szokásosan az alkotmányos identitás körében azonosított alkotmányi rendelkezéseknek már az identitáselmélet körén kívül is kiemelt figyelmet szentelt a jogtudomány. Számos elmélet és vizsgálat látott napvilágot, amelyek az alkotmányok érinthetetlen, alapvető rendelkezéseit kívánják meghatározni. ${ }^{333} \mathrm{Az}$ európai integráció és a „Szuverenitástranszfer” vonatkozásában Chronowski is azon alapvető alkotmányos rendelkezések érinthetetlenségére hívja fel a figyelmet, amelyek az Unió számára érinthetetlenek. ${ }^{334}$ Azon alkotmányos rendelkezések védelmének deklarációja, amelyek az alkotmányos rendszer alapvető struktúrájára és értékrendjére vonatkoznak, számos európai alkotmányban és alkotmánybírósági határozatban megjelenik, amely mögött egy

\footnotetext{
${ }^{331}$ Az explicit és implicit örökkévalósági klauzulák vizsgálatáról, illetve az örökkévalósági klauzuláknak az alkotmányos rendszerre, illetve az alkotmány stabilitására kifejtett hatásáról részletesen lásd: Szakály 2018.

${ }^{332}$ Vö.: Szakály-Tribl 2018

333 Többek között: Varga Zs 2011, Chronowski 2005, p. 49., Szmodis 2013, pp. 156-167.

334 Vö.: Chronowski 2005, p. 49., Varga Zs. 2011
} 
alkotmányos stabilitás és önmeghatározás iránti igény húzódik meg az alkotmányozó hatalom és az alkotmányértelmezők részéről. ${ }^{335}$

Amennyiben az adott tagállam - akár explicit, akár implicit módon - alkalmaz örökkévalósági klauzulát és az alkotmányos identitás meghatározására is tett már kísérletet az alkotmányértelmező, felmerül a kérdés, hogy a (jövőbeni) joggyakorlatban összekapcsolódik-e a kettő és ha igen, milyen mértékben. Ha ugyanis bizonyos rendelkezéseknek kiemelt védelmet biztosít az alkotmány, illetve az alkotmányértelmező explicit vagy implicit örökkévalósági klauzulaként, e kiemelt védelmi jelleg arra utal, hogy az adott rendelkezés meghatározó jelentőséggel bír az alkotmányos rendszer karakterisztikáját, önmeghatározását illetően. Ebből következően az örökkévalósági klauzulák akár explicitek, akár implicitek, olyan fontos és egyedi kérdéseknek tekinthetők, amelyekre szükségszerüen kiterjed az adott ország alkotmányos identitásnak hatóköre is, ezáltal részesítve ezeket az alapvető alkotmányos rendelkezéseket kvázi kettős védelemben. A két vizsgált fogalom bizonyos szemszögből ugyanazt a célt szolgálja: az alkotmányos berendezkedés legfontosabb elemeinek (alapvető szerkezetének, karakterisztikájának, meghatározó elveinek) védelmét.

Az örökkévalósági klauzula tehát az alkotmányos rendszer önmeghatározását az egyes alapvető intézmények, alapelvek és alkotmányos értékek szupremáciájával kívánja biztosítani és védelemben részesíteni még az alkotmánymódosító hatalomtól is. ${ }^{336}$ Kérdésként merül fel azonban, hogy mi történik, ha az így védelemben részesített alkotmányi rendelkezések nem az alkotmányos rendszeren “belülről” kerülnek veszélybe, hanem az alkotmányos rendszert meghatározó szupranacionális, "külső” faktor az, amely megkövetel(het)i az alkotmány ezen rendelkezéseit érintő (és adott esetben sértő) kötelező szabály alkotmányos rendszerbe illesztését?

E kérdés akként is feltehető, hogy miként viselkedhet egy örökkévalósági klauzulát alkalmazó tagállam, amennyiben az örökkévalósági klauzulában védett alkotmányos rendelkezés és az uniós jog között kollízió keletkezik? Lehetséges-e, hogy az Európai Unió Bíróságának gyakorlata szerint ${ }^{337}$ a tagállam arra kényszerül, hogy módosítsa az

\footnotetext{
335 Vö.: Szakály 2018, pp. 8-28.

${ }^{336}$ Vö.: Szakály 2018, pp. 98-102.

${ }^{337}$ Vö.: az EUB 6/64. sz. (Flaminio Costa v ENEL [1964]) döntése.
} 
alkotmány olyan rendelkezését, amelyet még az alkotmánymódosító hatalomtól is véd? A Cseh Alkotmánybíróság gyakorlata szerint ilyen lehetőség nem állhat fenn, mivel ebben az esetben a Cseh $\mathrm{AB}$ az alkotmány primátusát tartja követendőnek. ${ }^{338}$ Elméletben ilyen esetben egy tagállam előtt három út rajzolódik ki: Első lehetőség a közösségi jog alkalmazásának mellőzése. Ebben az esetben - elvileg - a tagállam az uniós jog megsértéséért alkalmazott (vagy nem alkalmazott) szankciókkal kerül szembe. (A német PSPP döntést követően a Bizottság gyakorlatilag azonnal kilátásba helyezte a kötelezettségszegési eljárás megindítását.) ${ }^{339}$ Második lehetőség az EUB által megfogalmazott követelmény szerint a tagállami alkotmány érintett rendelkezésének megváltoztatása. Örökkévalósági klauzulával nem védett rendelkezés esetében is problémás lehet ez az út - vö. a Cseh $\mathrm{AB}$ álláspontját -, örökkévalósági klauzula esetén azonban különösen, hiszen az csak új alkotmány elfogadása útján lehetséges. Ha a korábban bemutatott osztrák alkotmányt vesszük alapul, egy ilyen esetben népszavazás megtartása után kerülhetne sor a vonatkozó rendelkezés megváltoztatására. (Azzal természetesen, hogy az örökkévalósági klauzulákba foglalt rendelkezések általában olyan értékeket védenek, amelyek összeütközése a közösségi joggal inkább csak elméleti síkon létezik.) Végül, a harmadik lehetőség - amely álláspontom szerint szintén csak a „tervezőasztalon” létező kategória - a kollízió feloldhatatlansága esetén az integrációs folyamatból való kilépés. ${ }^{340}$

A fenti lehetőségek érdekes elméleti szcenáriókat vetnek fel, azonban álláspontom szerint a legvalószínübb egy negyedik forgatókönyv: hogy ezek a lehetőségek meg is maradnak az elmélet talaján, mert a tagállamok és az integráció közös elemi érdeke, hogy ilyen összeütközésekre ne kerüljön sor. (Ezért is kivételes jelentőségű a Német Szövetségi Alkotmánybíróság PSPP döntése, ahol az összeütközés egy hosszú folyamat következményeként elkerülhetetlenné vált.)

A kérdés egyúttal felveti az alkotmány egyes alapvető rendelkezéseinek, értékeinek védelmét, az európai kétszintű alkotmányosság rendszerében ${ }^{341}$ nemcsak az alkotmányos

\footnotetext{
${ }^{338}$ A Cseh Alkotmánybíróság gyakorlata szerint ilyen lehetőség nem állhat fenn, mivel ebben az esetben a Cseh AB az alkotmány primátusát tartja követendőnek. Bővebben lásd: Sulyok 2014, p. 56.

339 Vö.: https://eulawlive.com/commission-president-reacts-to-german-federal-constitutional-courtsruling-on-ecbs-pspp-programme/

340 Vö.: Gros 2020.

${ }^{341}$ Pernice 2006, p. 13.
} 
rendszeren belül (a védelem "belső oldala" az örökkévalósági klauzulák által), hanem az alkotmányos rendszeren kívül (a védelem "külső oldala" az alkotmányos identitás által) is.

Ez vezet el az alkotmányos identitás koncepciójának kontinentális értelmezési kérdéseihez, hiszen a tagállamok alkotmányértelmezőinek gyakorlatából kiolvashatóan $^{342}$ az alkotmányértelmezők e védelem eszközeként az alkotmányos identitás koncepcióját hívják fel leginkább. ${ }^{343}$ Ezt támasztja alá többek között az a tagállami tendencia, amely szerint az örökkévalósági klauzulát alkalmazó tagállamok alkotmányértelmezői a tagállam alkotmányos identitásának forrásaként az alkotmány örökkévalósági klauzulával védett rendelkezéseiben rögzített intézményeket, alapelveket és értékeket nevesítik. ${ }^{344}$

Az a tendencia, amely szerint az örökkévalósági klauzulákat alkalmazó tagállamok alkotmányértelmezői legalább részben azonos rendelkezéseket (értékeket, intézményeket) vonnak az örökkévalósági klauzula és az alkotmányos identitás hatókörébe, felveti azt a lehetséges következtetést, hogy az alkotmányos identitás koncepciója az örökkévalósági klauzulákat egyfajta új feladattal ruházza fel: a cél mindkét esetben a benne foglalt tartalom védelemben részesítése. Az örökkévalósági klauzulát alkalmazó tagállamok esetében azonban jóval egyszerübb az adott időpillanatban nevesíteni az alkotmányos identitás védendő értékeit, hiszen annak forrásaként, mint az alkotmány "legbelső, védendő magja" az örökkévalósági klauzula kerül nevesítésre.

Mind az örökkévalósági klauzulák, mind az alkotmányos identitás kérdése szorosan kapcsolódik egy állam önmeghatározásához, a kérdés azonban az, hogy az örökkévalósági klauzulákban foglalt értékek, rendelkezések és intézmények forrásául szolgálhatnak-e az adott tagállam alkotmányos identitásának? A kérdést illetően támogatható Polzin azon véleménye, amely szerint nem lehet egyenlőségjelet tenni a két fogalom tartalma közé, ${ }^{345}$ azonban minden esetben szükséges vizsgálni milyen

\footnotetext{
${ }^{342}$ Vö.: Sulyok 2014, Drinóczi 2016b, pp. 2-16., Drinóczi 2018b, pp. 65-72.

${ }^{343}$ A PSPP döntés tükrében kérdés, hogy vajon ez a tendencia kiegészül-e az ultra vires aktusokra vonatkozó gyakorlattal a jövöben.

${ }^{344}$ Vö.: Müller 2016, illetve Drinóczi 2018b, pp. 66-67.

${ }^{345}$ Polzin 2017, pp. 1607-1610.
} 
kölcsönhatás érvényesül(het) közöttük. Feltehetően a két fogalmi kör csak bizonyos részkérdésekben fedheti egymást, amelynek kiterjedése mindig egyedi vizsgálat tárgya. Míg az örökkévalósági klauzulák (explicit formájukban) változatlan sarokkövei az alkotmánynak, az alkotmányos identitás organikusan változó.

Kiemelendő ugyanakkor, hogy az alkotmányos identitás és az örökkévalósági klauzulák nem feltételezik egymást: az alkotmányos identitás a modern alkotmányos rendszerek tulajdonságaként értelmezhető, ezzel szemben az örökkévalósági klauzula választás eredménye. Következésképpen létezhet az alkotmányos rendszer örökkévalósági klauzula nélkül, azonban nem létezhet identitás nélkül. Örökkévalósági klauzula alkalmazása esetén azonban a védelem alá helyezett rendelkezések az alkotmányos rendszer olyan meghatározó intézményeit, illetve az alkotmány meghatározó rendelkezéseit védi, ${ }^{346}$ amelyek az alkotmányos rendszer identitásának megnyilvánulásai is egyben, és amelyeket az európai integrációban kiemelt értékként szükséges védelemben részesítenünk, (többek között) tekintettel az EUSZ 4. cikkére. Az örökkévalósági klauzulák és az alkotmányos identitás kapcsolatának vizsgálata során az explicit örökkévalósági klauzulát alkalmazó tagállamok esetén könnyebb a helyzet, mivel a védelemben részesített alkotmányi rendelkezések egzakt módon és taxatíve meghatározottak.

A fentiek alapján a kapcsolat az alkotmányos identitás és az örökkévalósági klauzulák között az alábbiakban foglalható össze:

(i) Az alkotmányozó hatalom az alkotmányos rendszer legalapvetőbb, inherens részének védelme érdekében az alkotmány és az alkotmányos berendezkedés egyes rendelkezéseit, intézményeit védelemben kívánja részesíteni.

(ii) Az európai integráció szupranacionális, többszintü alkotmányosságának rendszerét megelőzően ilyesfajta védelemre csak az alkotmányos rendszeren belül, az esetleges alkotmánymódosító hatalommal szemben volt szükség. A szupranacionális térben azonban az alkotmányozó - és az alkotmányértelmező - igénye ezen alkotmányos rendelkezések védelmére

\footnotetext{
${ }^{346}$ Stumpf István megfogalmazásában, egy korábbi identitás túlélésének zálogát jelenti, amely képes megakadályozni, hogy az alkotmányos rendszer valami egészen mássá alakuljon át, mint ami. Vö.: Stumpf 2020, p. 41.
} 
túlterjed az alkotmányos rendszer határain és azokat az integrációval szemben is védelemben kívánja részesíteni, amely az alkotmányos identitás koncepciójában ölt testet.

(iii) Az örökkévalósági klauzulát alkalmazó tagállamok örökkévalósági klauzulával védett alkotmányi rendelkezései és e tagállamok alkotmányos identitása között kapcsolat mutatható ki a fentiek szerint, melyet a védelem „,külső” és „,belső” oldalaként is kategorizálhatunk. 


\section{Egység a sokféleségben, vagy sokféleség az egységben? Alkotmányos identitás az európai integrációban}

\subsection{Az alkotmányos identitás külső oldala? Az EUSZ 4. cikk (2) bekezdése}

Az alkotmányos identitásra irányuló - európai - jogtudományi vizsgálódások egyik központi kérdése az EUSZ 4. cikk (2) bekezdésének értelmezése, mint az alkotmányos identitás uniós jogrendben megtalálható megfelelője. Elkülönítve egymástól az identitás külső és belső oldalát, az EUSZ vonatkozó rendelkezését helytállóbb az alkotmányos identitás külső oldalaként felfogni, hiszen nem ugyanannak a jelenségnek a két különböző és elhatárolható megjelenési formájáról van szó, sokkal inkább egyazon jelenség két különböző irányból történő megközelítéséről, illetve eltérő jogrendbéli alkalmazásáról.

Az EUSZ 4. cikk (2) bekezdés és az alkotmányos identitás kapcsolata az elmúlt években számos akadémiai vita tárgyát képezte és képezi a mai napig, ${ }^{347}$ azonban megfigyelhető az a tendencia - különösen a hazai jogirodalomban -, hogy a viták az idézett szakasz első fordulatára korlátozódnak, noha a teljes bekezdés kiegészül egy második, nem kevésbé fontos fordulattal. Ez utóbbi az EUSZ vonatkozó részének eredeti megszövegezésekor egységet alkotott a szüken értelmezett identitás-klauzulával. Az első fordulat szerint „, $a z$ Unió tiszteletben tartja a tagállamoknak a Szerzödések elötti egyenlöségét, valamint nemzeti identitását, amely elválaszthatatlan része azok alapvetö politikai és alkotmányos berendezkedésének, ideértve a regionális és helyi önkormányzatokat is." Számos értekezést találunk erről a fordulatról, különösen is a tekintetben, hogy hogyan értelmezendő, hogy a nemzeti identitás elválaszthatatlan része a tagállamok alapvető politikai és alkotmányos berendezkedésének. ${ }^{348}$ Kevesebb szó esik azonban a második fordulatról, amely szerint az Európai Unió „tiszteletben tartja az alapvető állami funkciókat, köztük az állam területi integritásának biztositását, a közrend fenntartását és a nemzeti biztonság védelmét. Így különösen a nemzeti biztonság az egyes tagállamok kizárólagos feladata marad.” Megjegyzést érdemel, hogy az eredeti szöveg (,,It shall respect their essential State functions...”) fordítása az „essential” szó jelentésére

\footnotetext{
${ }^{347}$ Vö.: Chronowski-Vincze 2017, pp. 118-119., Szabó 2019, p. 43., Drinóczi, 2016., stb.
}

${ }^{348}$ Vö.: Martinico 2013, pp. 93-109., Drinóczi 2016, Drinóczi 2018a, stb. 
tekintettel helyesebb lett volna ,lényegi” fordítással, vagyis az angol terminológia pontos adaptációja a „lényegi állami funkciók” tiszteletben tartása lenne.

Álláspontom szerint az EUSZ e rendelkezése megválaszolhatja az alkotmányos identitás és szuverenitás közötti elhatárolási kérdéseket, egyúttal az alkotmányos identitás európai értelmezésének egy szükítő értelmezési tartományát is jelenti, ezért vizsgálatom ezen része során célom az EUSZ 4. cikk (2) bekezdés második, alapvető állami funkciókra vonatkozó, illetve az identitás-klauzulát tartalmazó első fordulat kapcsolatának elemzése.

A tagállamok nemzeti identitásának védelme a Maastrichti Szerződéssel jelent meg, mint követelmény az uniós jogrendben, míg a tagállamok szerződések előtti egyenlősége (első fordulat), illetve az alapvető állami funkciók tiszteletben tartása csak a Lisszaboni Szerződés által bevezetett rendelkezések. ${ }^{349}$ Az EUSZ jelenleg ismert szövegének első változata az Alkotmányos Szerződés ${ }^{350}$ megszövegezésekor született és eredetileg a javaslat az alapvető tagállami funkciók (,,essential Member State functions”) kifejezést alkalmazta, amelyet a nemzeti identitás részeként fogott fel, azonban a rendelkezés később a tagállamok szuverenitásának védelme érdekében (!) a ma ismert formájában került be a Lisszaboni Szerződésbe. ${ }^{351}$

A javaslat eredeti formájában ${ }^{352}$ a nemzeti identitás elemeit kívánta meghatározni. Az ún. „Christophersen-clause”-t végül az előkészítő bizottság nem szavazta meg és az Alkotmányszerződés bukását követően a ma ismert formában került be a Lisszaboni Szerződésbe. ${ }^{353}$

A szöveg eredeti változatában az alábbi területek kerültek nevesítésre:

(i) Alapvető (alkotmányos) berendezkedés és alapvető tagállami funkciók (fundamental structures and essential functions of a Member State), mint például a politikai és alkotmányos berendezkedés - beleértve a regionális

\footnotetext{
349 Vö.: Blanke - Mangiameli 2013, p. 187., illetve Arnaiz -Llivina 2013, p. 3.

${ }^{350}$ Vö.: Angyal 2007, pp. 175-190.

${ }^{351}$ Blanke - Mangiameli 2013, p. 188.

352 Vö.: Blanke - Mangiameli 2013, p. 188., illetve a tervezetet bővebben lásd: http://europeanconvention.europa.eu/pdf/reg/en/02/cv00/cv00251.en02.pdf

${ }^{353} \mathrm{Az}$ Alkotmányszerződés elfogadásának és bukásának körülményeit jelen értekezés 4.3.2. fejezetében vizsgálom.
} 
és helyi önkormányzati rendszert, az állampolgárság, a területi integritás, az egyházak és vallási közösségek státusza, a nemzetbiztonság és fegyveres erők, illetve a nemzeti nyelv védelme;

(ii) Alapvető politikai döntések és a tagállamok társadalmi értékei (,, basic public policy choices and social values of a Member State”), mint például jövedelemmegosztási politika, adórendszer, szociális ellátások rendszere, oktatási rendszer, közegészségügyi rendszer, a kultúra megőrzése és fejlesztése, kultúrpolitika, kötelező katonai és közösségi szolgálat. ${ }^{354}$

A Lisszaboni Szerződés (EUSZ) szövegébe végül a nemzeti identitás és az alapvető (tag)állami funkciók egyazon bekezdésbe, de eltérő fordulatban kerültek szabályozásra. Ez arra enged következtetni, hogy a szerződés megszövegezésekor a nemzeti identitás és az alapvető állami funkciók közötti lehetséges rész-egész viszonyt a jogalkotó nem tartotta követendő útnak. Ez a döntés egyúttal fontos értelmezési támpontot jelenthet az EUSZ 4. cikk (2) bekezdés értelmezéséhez, illetve a nemzeti identitás fogalmának meghatározásához is.

Érdemes továbbá megjegyezni, hogy a nemzeti identitás - javaslat szerinti - védendő elemei közül számos elem végül nem került be a szerződés szövegébe. A javaslathoz képest az EUSZ-ben nem jelenik meg az állampolgárság, az egyházak és vallási közösségek státusza, a nemzeti nyelv védelme, a jövedelemmegosztási politika, az adórendszer, a szociális ellátások rendszere, az oktatási rendszer, a közegészségügyi rendszer, a kultúra megőrzése és fejlesztése, a kultúrpolitika, illetve a kötelező katonai és közösségi szolgálat.

${ }^{354}$ Blanke - Mangiameli 2013, p. 195. Az javaslat eredeti - angol - szövegét bővebben lásd: CONV 375/1/02 REV 1, 11. - http://european-convention.europa.eu/pdf/reg/en/02/cv00/cv00375-re01.en02.pdf 


\subsubsection{Az identitás klauzula: az EUSZ 4. cikk (2) bekezdés első fordulata}

Az első fordulat értelmezése tekintetében az első és legfontosabb lépés természetesen a nemzeti identitás tartalmának megállapítása, majd ezt követi az alkalmazás problémaköre: ki és mikor állapíthatja meg a nemzeti identitás tartalmát, illetve hogyan alkalmazható mindez a tagállami alkotmányok és az uniós jog viszonyának meghatározásakor?

Valamennyi, az alkotmányos (az EUSZ fogalomhasználatában nemzeti) identitás tárgyában folytatott vizsgálat központi problémáját jelenti a fogalmi, terminológiai inkonzisztencia, a pontos fogalmi elhatárolások hiánya, amelyek részbeni megoldásához jelen értekezés is hozzá kíván járulni. Általánosságban elmondható - a korábbiak szerint -, hogy az EUSZ-ben szereplő és az EUB által alkalmazott nemzeti identitás terminológiát a jogtudomány számos képviselöje és a legtöbb tagállami alkotmánybíróság az alkotmányos identitás jogtudományi fogalmával azonosítja. ${ }^{355}$

Az alkotmányos identitás koncepciójának alkalmazhatóságát, vagy alkalmazásának módját számos esetben kétségbe vonja - különösen a hazai - jogtudomány ${ }^{356}$-, amelynek egyik legföbb oka - a fogalmi meghatározatlanságon kívül - a fogalom politikai színezete. Az alkotmányos identitás az Európai Unióban politikai tartalommal felruházott fogalommá vált, amely az alkotmányjogi gondolkodásban - mind a joggyakorlat, mind pedig a jogtudomány oldaláról - a tagállamok integrációval szembeni ellenállási törekvéseit fejezi ki. Egy olyan, kvázi európai ius resistendi ${ }^{357}$, amelyben a tagállamok vagy legalább is a tagállamok egy része - a felhatalmazás nélküli, az uniós hatáskörök kiterjesztése révén alkotott aktusok - ultra vires ${ }^{358}$ - problémájának megoldását, vagy legalább is a megoldás lehetőségét véli felfedezni. ${ }^{359}$ (Amennyiben a Német Szövetségi Alkotmánybíróság PSPP döntésének szemléletéből indulunk ki, az ultra vires aktusok és az alkotmányos identitás elkülönülő, egymást kvázi kiegészítő problémakört alkotnak, amely megközelítéssel magam is egyetértek. Az alkotmányos identitás és az ultra vires aktusok kapcsolatával a PSPP döntésben a későbbiek során részletesen is foglalkozom.)

\footnotetext{
${ }^{355}$ Blanke - Mangiameli 2013, p. 187., Szabó 2019, p. 43., Orbán 2018, pp. 1-2., Drinóczi 2016b, pp. 214.

${ }^{356}$ Vö.: Chronowski - Vincze 2017, pp. 116-119, 125-126., Drinóczi 2016b, pp. 34-42.

${ }^{357}$ Az ellenállási jogról bővebben lásd: Degré 1980, pp. 366-371.

${ }^{358}$ Vö.: Drinóczi 2017b

${ }^{359}$ Vö. Vincze-Chronowski 2018, pp. 375-449.
} 
Az alkotmányos identitásról kialakult viták során legtöbbször értékek - de legalább is értékek mellett felsorakoztatott érvek - állnak egymással szemben, amelyek valóban politikai tartalmat hordoznak. Ez azonban nem jelenti azt, hogy maga az alkotmányos identitás koncepciója egy egyszerű politikai eszköz lenne, amely tartalom nélküli lehetőséget biztosít az adott törekvés számára. Visszacsatolva az ellenállás jogának példájához, az Aranybulla megfogalmazását megelőzően az ellenállási jog pusztán egy politikai törekvés formájában létezett. Nem volt több, mint a két egymással versengő erőtér - ti. az uralkodó és a nemesség - közötti feszültség által életre hívott kompromisszum, egy érinthetetlen konszenzus részeként. Egy olyan törekvés, amely szokatlan, sőt elképzelhetetlen volt a korábban fennálló rendben, mégis a következő évszázadok alkotmányos berendezkedésének egyik meghatározó elvévé nőtte ki magát.

Az alkotmányos identitás felhívására irányuló tagállami igényekből kettős alkalmazási dimenzió olvasható ki: a tagállami integritás, a tagállami legfőbb hatalom, vagyis a szuverenitás védelme az integrációval szemben (i), illetve az egyes tagállamokra jellemző alkotmányos értékek ${ }^{360}$, egyedi tagállami jellemzők védelme (ii) iránti igény. ${ }^{361} \mathrm{~A}$ legmarkánsabb példája e kettős igényrendszernek talán éppen a magyar alkotmánybírósági gyakorlat, ahol az alkotmánybíróság egyazon határozatában, egymásra tekintettel hozza létre és alkalmazza a szuverenitás és az identitás tesztjét.

Az európai integráció egy olyan államelméleti kategóriát teremtett, amely történelmi dimenzióban párja nélküli, egyúttal azonban számos olyan új alkotmányjogi megoldást is életre hívott, amelyek az integráció jellegéből törvényszerüen következnek, mint például a szupranacionalitás és az ahhoz kapcsolódó jogelvek. ${ }^{362}$ A tagállamok igénye a szuverenitás védelmére, illetve a tagállam inherens (elválaszthatatlan) alkotmányos és politikai berendezkedésére jellemző egyedi elemek megőrzésére e folyamatoknak okozatossági alapon - következményeként minősíthető. Ezek a tagállami igények ugyanúgy megjelennek az Unió politikai színterein, mint ahogy jelen vannak a jogi dimenzióban is: a nemzeti alkotmánybíróságok, illetve az EUB joggyakorlatában.

\footnotetext{
${ }^{360}$ Bulmer 2014, pp. 6-7., Takács 2007, p. 28.

${ }^{361}$ Vö.: 22/2016 ABH.

362 Vincze - Chronowski 2018, pp. 20-28.
} 
Az európai integráció jellegénél fogva egy örökös feszültségben él: a globalizált nemzetközi környezetben ${ }^{363}$ kialakuló gazdasági erőközpontok arra kényszerítik az európai nemzeteket, hogy egységes entitásként jelenjenek meg a nemzetközi jog és a nemzetközi gazdaság szereplőjeként. ${ }^{364} \mathrm{E}$ nemzetek azonban nem alkotnak egységes társadalmat - démoszt ${ }^{365}$-, így a társadalmi és kulturális, nemzeti különbözőségek nem teszik lehetővé a homogén, egységes fellépést. Európa egyelőre legalább is nem ezt az utat választotta. Az ennek ellenére létrejövő szupranacionális berendezkedés tehát a globalizált nemzetközi térben szükségszerü együttmüködés eredménye, amely arra készteti az európai nemzeteket, hogy hasonlóságaik, közös értékeik révén egységbe (a kortárs nemzetközi kapcsolatok egyik legfontosabb nem állami szereplőjének egységébe) tömörüljenek.

Az egységes társadalom, a démosz hiányában azonban az önálló, szuverén nemzetekböl álló szupranacionális entitás életre hívja a tagállami alkotmányok és az integrációs jogrend (értékrend!) összeütközésének problémakörét, ${ }^{366}$ illetve egyúttal próbára teszi a szuverenitásról alkotott nézeteink alkalmazhatóságát. ${ }^{367}$ Ebben a környezetben az alkotmányos identitás, mint a tagállamok fenti igényének materializálódása érhető tetten különösen a tagállami alkotmánybíróságok joggyakorlatában. ${ }^{368}$

\footnotetext{
363 Vö.: Tushnet 2008

364 Vö.: 4.2.1. fejezet.

365 Vö.: Paczolay 2000

${ }^{366}$ Ld. a fentiekben a magfúziós hasonlat kapcsán írt Coulomb-feszültség említését.

367 Vö.: Blutman 2019

${ }^{368}$ A gyakorlat egy részének feltérképezését bővebben lásd például: Drinóczi 2016 b.
} 


\subsubsection{Alapvető állami funkciók: az EUSZ 4. cikk (2) bekezdés második fordulata}

Míg az első fordulat a tagállamok alkotmányos és politikai berendezkedésének egyedi jellemzőit, alkotmányos identitását hivatott védeni - tagállamonként eltérő tartalommal -, az alapvető állami funkciók tiszteletben tartása objektív kategóriát képez, amely az integráció valamennyi tagállamára azonos tartalommal, a tagállami minőségre (és nem a tagállami identitásra) tekintettel vonatkozik ${ }^{369}$ és amelyet a Francia Alkotmánytanács a „,nemzeti szuverenitás gyakorlásához szükséges alapvető feltételek”-ként aposztrofált. ${ }^{370}$

A szerződés szövege nyitott katalógust alkalmaz és - különösen - mint alapvető állami funkciót határozza meg az állam területi integritásának biztosítását (i), a közrend fenntartását (ii) és a nemzetbiztonság védelmét (ii). ${ }^{371}$

Megjegyzést érdemel továbbá, hogy az alkotmányos identitás koncepciójának egyik legnagyobb kritikája, hogy az euroszkeptikus politikai törekvések az integrációs folyamattal szemben kívánják alkalmazni. Ugyanakkor, ha az EUSZ vonatkozó bekezdésének két fordulatát elkülönülten - de egymásra tekintettel - értelmezzük, akkor láthatóvá válik, hogy az euroszkepticizmus legjelentősebb aggálya, a nemzeti szuverenitás háttérbe szorulása nem az alkotmányos identitás - mint az egyes tagállamok egyedi alkotmányos berendezkedéséből fakadó sajátos jellemzők, illetve értékek -, hanem az alapvető állami funkciók kérdésköre.

A kérdés, amit e tudományosan hanyagolt második fordulattal kapcsolatban fel kell tennünk az, hogy mit tekintünk „,alapvető állami funkciók” alatti kategóriának, tekintettel a szerződés által alkalmazott nyílt végü felsorolásra? Az EUSZ által kiemelt esetkörök, mint az állam területi integritása, vagy a közrend fenntartása, az állami föhatalom körébe eső elemekre utalnak, amely - a Francia Alkotmánytanács megítélésének megfelelően a szuverenitás kérdése felé tereli a második fordulat értelmezését, hiszen az alapvető állami funkciók tiszteletben tartásával az EUSZ gyakorlatilag az azok alapjául szolgáló tényt, az állam egy alapvető ismérvét, a szuverenitást vonja - sajátos módon - a védelem

\footnotetext{
${ }^{369}$ Blanke - Mangiameli 2013, p. 228.

${ }^{370}$ Uo., illetve vö. az Alkotmánytanács 2004-505 DC számú döntését (2004. november 19.)

${ }^{371}$ Érdekes elméleti problémát jelenthet egy későbbi kutatás számára az EUSZ ezen fordulata és a 2015-ös migrációs válság okozta politikai feszültségek, pontosabban az ezekre visszavezethetően született jogi érvelések összevetése és vizsgálata.
} 
hatókörébe. Jogi szempontból azonban számos és mostanra jól ismert problémát hordoz a szuverenitás meghatározása és alkalmazása a szupranacionális környezetben. ${ }^{372}$

Egyrészről a többszintű alkotmányosság rendszerében a szuverenitás értelmezéséhez a már ismertetettek szerint el kell különítenünk a szuverenitás jogi és politikatudományi felfogását. ${ }^{373}$ Jogi értelemben a szuverenitás (a szuverén állam) szokásosan a területen lakó népesség felett gyakorolható főhatalom együttesével írható le (amelyekre az EUSZ 4. cikk (2) bek. második fordulata által nevesített alapvető állami funkciók körébe vont esetkörök vonatkoznak is), kiegészülve természetesen a szuverenitás külső oldalával, vagyis a nemzetközi közösség általi elfogadottsággal. A szuverenitás jogi megítélése azonban nem fekete vagy fehér, különösen a szupranacionális, többszintü alkotmányosság rendszerében, ${ }^{374} \mathrm{a}$,,Szuverenitásegyesítő” keretek között. ${ }^{375}$ Kérdésként merül fel ismételten a szuverenitás korlátozható, vagy korlátozhatatlan, illetve - horribile dictu! - osztható, vagy oszthatatlan jellege. ${ }^{376}$ Az EUSZ vizsgált fordulata szempontjából azonban nem is annyira a szuverenitás jogi megítélése a kérdés, mint inkább annak meghatározása, hogy melyek azok a klasszikusan az államot természetéből - vagyis sokkal inkább szuverenitásából - fakadóan kizárólagosan megillető alapvető funkciók, amelyeket az integrációnak tiszteletben kell tartania és mindez hogyan hat az európai jogrendre. A kérdés politikai dimenziója ismételten a szuverenitás politikatudományi felfogásából ered: a végső politikai döntés meghozatalának joga, amely minden esetben politikai tartalmú és nem jogi döntés. ${ }^{377}$ Kereteit tekintve az alkotmányjog doktrinális kereteibe foglalt, tartalmában azonban végső soron politikai döntések összessége, amelyekhez a főhatalom birtokosaként az államot megillető jogok és kötelezettségek társulnak. $^{378}$

Az uniós jogrend eredendően a szuverén tagállamok önkorlátozására, önkéntes részvételére - társadalmak közötti szerződésre? - épül. ${ }^{379}$ Ezért önmagába harapó kígyó látszatát keltheti egy olyan (alkotmány)jogi dilemmát létrehozni, amely a tagállamok és

\footnotetext{
372 Vö.: Blutman 2019, pp. 79-90.

${ }^{373}$ Vö.: Bihari- Pokol 2013, illetve Rigó Anett: Szuverenitás és legitimitás, a szuverén államtól a globális kormányzásig? URL: http://dfk-online.sze.hu/images/JÁP/2009/1/rigó.pdf

374 Vö: Blutman 2019, pp. 87-89.

375 Vö: Fekete 2017

376 Vö: Blutman 2019, pp. 82-83.

377 Körösényi 2004, p. 158.

${ }^{378}$ Bihari-Pokol 2013

${ }^{379}$ Blanke - Mangiameli 2013, p. 229.
} 
az integráció feloldhatatlan szembenállását feltételezi, majd megkísérelni azt megoldani. Ez azonban azt is jelenti, hogy a tagállamok az Unió jogrendjét - tagállammá válásukkor - magukra nézve kötelezöként kell, hogy elismerjék és mint ilyen, a csatlakozás pillanatától kezdve az integráció részes államaként határozzák meg önmagukat, megtartva azonban alapvető állami funkcióikat, amelyeket a Szerződés is védeni rendel.

A csatlakozás ezért természetesen nem jelent sem asszimilációt, sem pedig azt a kötelezettséget nem rója a tagállamokra, hogy az uniós intézmények esetleges ultra vires aktusait elfogadják, azokat végrehajtsák (vö. PSPP döntés!). Jelenti ugyanakkor azt a kötelezettséget, hogy a tagállamok az Alapító Szerződések rendelkezéseit magukra nézve kötelezőnek fogadják el, amelynek egyenes következménye, hogy a Szerződések értelmezőjeként az Európai Unió Bíróságának jogértelmezése erga omnes hatállyal bír a Szerződések hatókörén belül. ${ }^{380}$ Mindez természetesen a szűken értelmezett európai jog szempontjából evidenciaként kezelendő, azonban ebből a mechanizmusból fakad, legalábbis elvileg - hogy a Szerződések értelmezőjeként az Európai Unió Bírósága jogosult annak meghatározására, vélhetően esetről esetre, hogy mi minősül az EUSZ 4. cikk (2) bekezdés második fordulatának hatálya alá tartozó alapvető állami funkciónak, amely ettől a pillanattól kezdve valamennyi tagállamra általánosan vonatkozó döntés, tekintettel a tagállamok szerződések előtti egyenlőségének követelményére.

Ugyanakkor jelenti ez azt is, hogy ebben az értelmezésben egy, az integráció által létrehozott szerv - EUB - jogosult dönteni arról, hogy mit tekint olyan alapvető állami funkciónak, amelynek tiszteletben tartására az integráció köteles, amely így ismét felveti - egy másik megközelítésben - az önmagába harapó kígyó problémáját és az integráció dominanciáját vetíti előre az azt létrehozó tagállamokkal szemben, azonban erre irányuló és közvetlenül kinyilvánított tagállami akarat hiányában. ${ }^{381}$ Ez pedig már felvetheti - és a PSPP döntéseben fel is veti - az ultra vires aktusok értelmezésének egy speciális esetkörét.

$\mathrm{Az}$ európai integráció működése természetesen feltételez egy alapvető politikai konszenzust a fenntarthatóság tekintetében, hiszen a tagállamok szuverenitásból fakadó korlátozhatatlan joga annak eldöntése, hogy az európai integráció tagállamaként

\footnotetext{
${ }^{380}$ Vincze - Chronowski 2018, pp. 493-515.

${ }^{381}$ Vö. korábban a lopakodó föderalizmus jelenségét.
} 
kívánják-e meghatározni önmagukat. Ez is egy alapvető állami funkciójukból, önrendelkezési jogukból fakad. Amennyiben azonban ez az önmeghatározás megtörténik, úgy az (alkotmány)jogi keret megváltoztatására csak az integráció jogrendjének határain belül van lehetőség, amelyhez szintén széleskörü politikai konszenzusra van szükség az európai nemzetek között. 


\subsubsection{Következtetések az EUSZ 4. cikk (2) bekezdéséről}

Az EUSZ 4. cikk (2) bekezdése a tagállami integritás védelmének három dimenzióját határozza meg: egyrészröl az unió tiszteletben tartja (kell, hogy tartsa) a tagállamok szerződések előtti egyenlőségét (i), nemzeti identitását (ii) és alapvető tagállami funkcióit (iii). E hármas védelem hivatott garantálni, hogy az európai integráció többszintü alkotmányos, szupranacionális rendszerében az unió tagállamainak alapvető alkotmányos berendezkedése, állami integritása a tagállammá válást követően is biztosított legyen, ${ }^{382}$ ezért az elemzett 4. cikk (2) bekezdésének két fordulatát egymásra tekintettel, de elkülönülten kell értelmezni.

Az első fordulat tartalmazza a szoros értelemben vett identitás-klauzulát, amely a tagállamok alkotmányos berendezkedésének egyedi elemeit hivatott védelemben részesíteni: a tagállami alkotmányos berendezkedések azon intézményeit, alkotmányban rögzített értékeit, amelyek kizárólag az adott alkotmányos berendezkedés - történelmi fejlődés eredményeként létrejövő - egyedi jellemzőiként tekintendők (P1. laicitás Franciaország, történeti alkotmány vívmányai - Magyarország, köztársasági államforma és emberi méltóság - Németország, stb.). Az EUSZ rendelkezése folytán az Unió köteles tiszteletben tartani a tagállamok ezen egyedi alkotmányos elemeit és mint ilyen, ezen tagállami értékek védelme feltehetően az uniós jog korlátját képezhetik.

A második fordulat szerint az Unió tiszteletben tartja a tagállamok alapvető állami funkcióit, amely rendelkezés értelmezhető - a fentiek szerint - kvázi a szuverenitás klauzulájaként is: az alapvető állami funkciók meghatározása olyan generális kérdés, amely valamennyi tagállamra általánosan vonatkozik. A tagállamok alkotmányának és az uniós jogrend összeütközésének kérdése olyan fundamentális viszonyrendszert feltételez, amely valamennyi tagállam esetén azonos tartalommal kell, hogy bírjon. A tagállami alkotmányok és az uniós jogrend összeütközésének ,általános”, szuverenitási kérdésekre visszavezethető esetei - amelyek a hatáskörátruházásra vezethetők vissza - az EUSZ 4. cikk (2) bekezdés második fordulata alapján oldhatók fel. Természetesen kérdésként merül fel, hogy az EUSZ által védett állami funkciókat érint-e, illetve érintheti-e a hatáskörmegosztás, illetve a szuverén hatalomgyakorlást az állam egy alapvető

\footnotetext{
382 Blanke - Mangiameli 2013, p. 187.
} 
funkciójának tekintjük-e, vagy sokkal inkább az állam tulajdonságának? Ha elfogadjuk az EUB szupremáciáját a kérdésben, az felveti a problémát: mi van, ha az EUB eldönti e kérdéseket az „integráció javára”? Ebben az esetben vajon az integráció egy szerződésekből fakadó jogosultságának gyakorlásával megsértené a szerződésekből fakadó együttmüködési kötelezettségét?

A két fordulat közül tehát az első egyedileg, esetről esetre vonatkozik a tagállamokra és minden esetben egyedi mérlegelés tárgya (nemzeti identitás), míg a második fordulat a szuverenitás európai integrációban történő érvényesülésének uniós jogi klauzulája, amely valamennyi tagállam esetében azonos tartalommal bír.

Ha elfogadjuk a két fordulat elkülönítését, akkor láthatóvá válik, hogy a nemzeti identitás EUSZ-ben rögzített védelme az egyedi tagállami jellemzőkre vonatkozik. Olyan tagállami értékekre, amelyek az egyes nemzetek sajátjai. Némi szentimentalizmussal akár azt is mondhatjuk, hogy a nemzeti identitás tiszteletben tartására vonatkozó uniós kötelezettség a tagállamok ,lelkét” védi. A nemzeti identitás tiszteletben tartása olyan integrációs kötelezettségként jelenik meg, amely a tagállamokat azok szuverén természetére tekintettel illeti meg. Ezen a ponton válik el igazán a két fordulat. Az alapvető állami funkciók tiszteletben tartása ugyanis egy fokkal pragmatikusabb tartalmat hordoz: valamennyi állami funkció tiszteletben tartásának kötelezettségét, amely állami funkciók a tagállamok szuverén természetének leképeződései. Az EUSZ e fordulata nem tartalmaz szúkítést - csak kiemelést -, vagyis a kiindulópont a szuverenitásból fakadó valamennyi funkció elismerése. Ez tehát a főszabály, a kiindulópont, amelyhez képest az egyes állami funkciók gyakorlása - hatáskörökön keresztül -, szigorú elvrendszer és eljárásrend szerint oszlik meg az integráció és a tagállamok között. Ez a megközelítés teszi az integrációt azzá, ami: szuverén nemzetek önkorlátozó közösségévé. Álláspontom szerint ez azonban azt is jelenti, hogy a két fordulat két eltérö attribútumot véd: a nemzeti identitás egy következményt - a szuverén természetböl fakadó egyediséget -, míg az állami funkciók védelme magát a szuverén természetet.

A vizsgált fordulatok elválasztása és egymástól elkülönülten történő értelmezése alapján tehát az a következtetés vonható le, hogy az EUSZ e rendelkezése a nemzeti, vagy alkotmányos identitás fogalmának szűkítő értelmezését jelenti. Európai értelmezésben a tagállamok és az integráció viszonyából fakadó szuverenitási kérdések nem tartoznak a 
nemzeti / alkotmányos identitás fogalmi köréhez, azok tudományos szempontból államelméleti, míg döntéshozatali szempontból politikai kérdésekként értelmezhetők.

Az EUSZ 4. cikk (2) bek. alkalmazási lehetőségeinek számbavételekor minden esetben figyelembe kell vennünk azonban, hogy az abban, az Unióra kiszabott kötelezettségek szorosan kapcsolódnak az 5. cikkben foglalt elvekhez, vagyis az EUSZ hivatkozott rendelkezései csak az 5. cikkben foglalt hatáskörátruházás, szubszidiaritás és az arányosság elveivel együtt, rendszerben értelmezhetők. E két cikk rendelkezéseinek célja pedig végső soron az, hogy összehangolja az integráción belüli centripetális (vö.: EUSZ 2-3. cikk - közös célok és azonos értékek), illetve centrifugális (nemzeti függetlenség és különbözőségek) erőket, amelyek kiegyensúlyozása - zéró összegü játszmája? ${ }^{383}$ - az integrációs folyamat fejlődésének kulcskérdése. ${ }^{384}$

383 Vö.: Forgó 2009, pp. 515-516.

${ }^{384}$ Blanke-Mangiameli 2013, p. 187. 


\subsubsection{A tagállamok és az integráció viszonya az EUSZ 4. cikk (2) tükrében}

Összegezve az alkotmányos identitás természetéről lefektetetteket, azt (a szuverenitás analógiájára) két irányból kell megközelítenünk és el kell határolnunk annak belső és külső oldalát. Mikor az alkotmányos berendezkedést „önmagában” vizsgáljuk, az alkotmányos identitás egyes jegyei az alkotmányos rendszert alkotó tényezők alkotmányos közösség, alkotmányozó hatalom, alkotmány - egymással alkotott kölcsönhatásából, konfrontatív viszonyából születnek.

Egy természetes folyamat, amely során kialakulnak az alkotmányos berendezkedést kialakító alkotmányos közösség természetének megfelelő, az alkotmányban visszatükröződő és magát az alkotmányos berendezkedést meghatározó identitásjegyek, amelyek védelmére az alkotmányozó, illetve az alkotmányértelmező is törekszik (pl. örökkévalósági klauzulák által). Ezt tekinthetjük az alkotmányos identitás belső oldalának. Jacobsohn az indiai legfelsőbb bíróság gyakorlatát említi, amelynek értelmében az alkotmány módosításai az alkotmányos rendszer védelme érdekében vizsgálhatók a LB által, vagyis India esetében az alkotmányos rendszer identitásának védelme felülemelkedett az alkotmánymódosítás alkotmányossági kontrolljának tilalmán, ${ }^{385}$ miután kollízióba került azzal. ${ }^{386}$ (Az indiai gyakorlatot érdemes összevetni a hazai alkotmánybírósági gyakorlattal, amely szerint az AB az Alaptörvény módosításait tartalmi szempontból nem vizsgálhatja.)

Másrészről, amennyiben az adott alkotmányos rendszert a szupranacionális együttmüködés viszonylatában vizsgáljuk, úgy az alkotmányos identitás már egyfajta esszenciális védelemként jelentkezik, amely az adott állam alkotmányos berendezkedését óvja attól, hogy az nemzetközi kötelezettségvállalások és a szupranacionális jogrend révén „valami egészen mássá alakuljon át.” Az európai integrációban ez az esszenciális védelmi funkció különös jelentőségűvé emelkedik, hiszen a tagállamok ugyan őrzik szuverenitásukat, azonban a hatáskörtranszfer folytán a szuverenitásból fakadó döntési jogosultságukról a szükséges mértékig az integráció érdekében lemondanak. ${ }^{387}$

\footnotetext{
385 Vö.: 45/2012 (XII.29.) AB határozat, illetve Szakály 2018, pp. 178-180.

386 Jacobsohn 2013, p. 8.

${ }^{387}$ Vö. Chronowski 2005, p. 48.
} 
Az EUSZ 4. cikk (2) bekezdés alapján a hatáskörtranszferböl következö, a tagállami alkotmányok és az uniós jogrend közötti összeütközés a második fordulatban foglalt alapvető állami funkciók meghatározásának kérdésétől függ. ${ }^{388}$ Mikor a tagállami szuverenitás kollízióba kerül a szupranacionális entitással, a kérdés az, hogy a szuverenitásból fakadó döntési jogosultságokról a tagállamok milyen körben mondhatnak le, hogy tagállami mivoltuk, - és így végső soron az EU identitása! - már ne sérüljön. ${ }^{389}$

Az európai integráció jelenleg a szuverén tagállamok együttmüködésén alapul, vagyis, ha a tagállamok az alkotmányos berendezkedésük egyediségét kifejező értékeket feláldoznák, „lecsupaszítanák” önmagukat, az végső soron egyben az integráció szupranacionális természetéből fakadó fundamentális müködési elveit is sértené, vagyis sérülne az EU identitása. (Egység a sokféleségben és nem sokféleség az egységben.)

Ennek biztosítása érdekében, a tagállamok alkotmányos berendezkedésének egyediségét megtestesítő alkotmányos identitásra, amelynek tiszteletben tartása az Unió kötelezettsége, az EUSZ 4. cikk (2) bekezdés első fordulata alapján kerülhet sor (az alkotmányos identitás külső oldala). Az alkotmányos külső és belső oldalának megjelenését, illetve a szupranacionális rendszerben érvényesülő hatásmechanizmust az 5. sz. ábra szemlélteti.

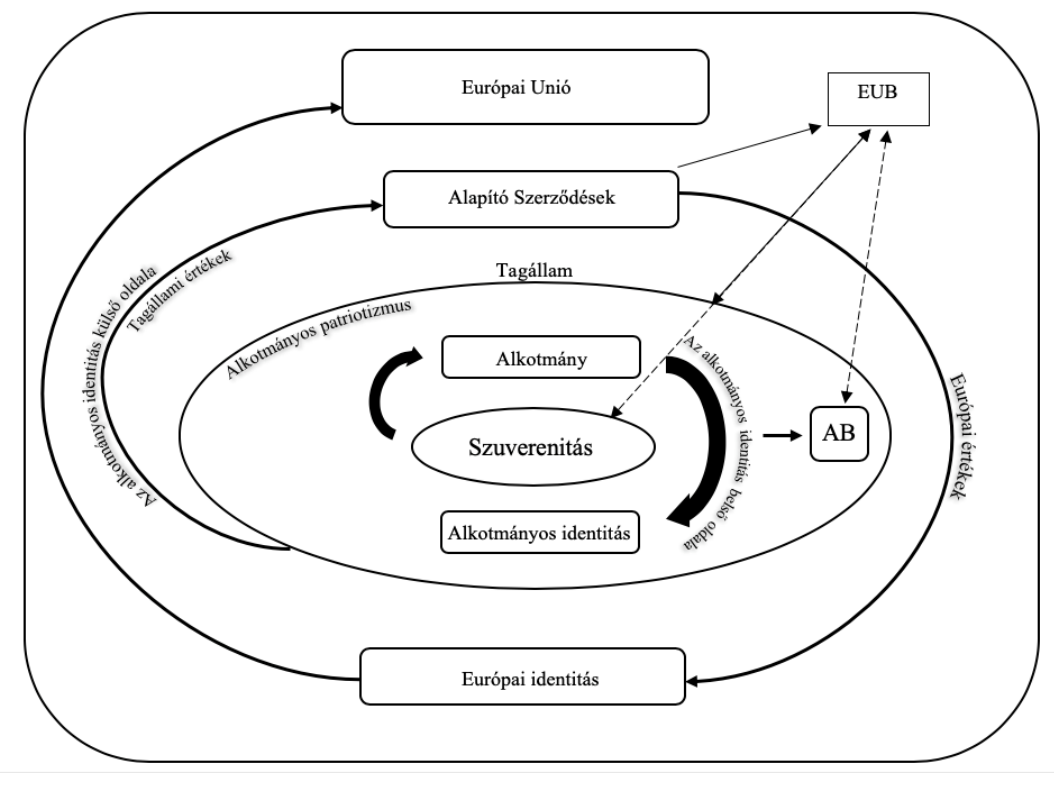

5. sz. ábra: Az alkotmányos identitás a szupranacionális térben

(saját szerkesztés)

388 Vö.: Az alkotmánybíróságok és az EUB „hatásköri” összeütközésének problémáját.

${ }^{389}$ Vö. a kompozit alkotmányosság kérdésköre, bővebben lásd: Besselink 2007. 
Látható, hogy az alkotmányos identitás problémaköre az integráció és a tagállamok egymással alkotott konfrontatív viszonyában teljesedik ki a maga egészében: az identitásképzés modelljében meghatározott körforgás - amelynek eredményeként megjelennek az identitásjegyek - megismétlődik egy második szinten, ahol a kollektív identitás hordozója már a szupranacionális entitás, míg kialakítói az integrációt alkotó tagállamok. Ezen a szinten, hasonlóan a tagállami dimenzióhoz, az identitásképzésből fakadó konfrontatív viszony kihatással van magára a kollektív identitásra és visszahat az azt létrehozó szubjektumok (ebben az esetben a tagállamok) identitására. Ebből a szempontból az identitásképzés mechanizmusa nem koncepció, hanem törvényszerüség, amelynek megléte független attól, hogy elfogadjuk, vagy alkalmazzuk-e az alkotmányos identitást, mint jogtechnikai eszközt. Az identitásképzésből fakadó feszültség valamelyest még a tagállami alkotmánybíróságok és az EUB gyakorlatától is független: azok részesei és formálói az identitásképzésnek, de végső soron nem urai annak. A kérdés ezen a ponton az, hogy az integráción belül hogyan képeződik le mindez a gyakorlatban? Hogyan formálja az identitásképzés e mechanizmusa az integrációt?

Az EUB Internationale Handelsgesellschaft döntésének ${ }^{390}$ jelentőségét vizsgálva (amelyben a testület megállapította, hogy a tagállamok nem hivatkozhatnak saját alkotmányos berendezkedésükre a közösségi joggal szemben), Trócsányi 2014-ben kifejti, hogy a közösségi jog elsőbbségének abszolút értelmezése a tagállami alkotmányok marginalizálódásához vezethet, ${ }^{391}$ majd - nemzetközi szerzőkre hivatkozással - az alkotmányos identitásra, mint a tagállamok kitörési pontjaira utal. ${ }^{392}$ Trócsányi, továbbá, úgy tekint az EUSZ identitás-klauzulájára, mint a „tagállami szuverenitás védelme érdekében, az Unióval szemben felállított korlát[ra]”. 393

Gyakorlati szempontból a felmerülő kérdések az alábbiakban foglalhatók össze:

(i) A tagállamok mikor és hogyan hivatkozhatnak alkotmányos identitásukra,

(ii) milyen szinten (EU-s vagy tagállami),

\footnotetext{
390 Case 11-70, Internationale Handelsgesellschaft mbH v Einfuhr- und Vorratsstelle für Getreide und Futtermittel (1970. december 17.)

391 Trócsányi 2014 a, p. 75.

392 Megjegyzendő, hogy Trócsányi alkotmánybíróként párhuzamos indokolásában már 2010-ben kifejtette, hogy a tagállamok megtartották az államrendjük fenntartásához nélkülözhetetlen alapvető elvek feletti rendelkezési jogot, melyek elöfeltételei az államiság, és így az alkotmányos identitás védelmének. (Vö.: 143/2010 (VII.14.) ABH Trócsányi László párhuzamos indokolása.)

393 Trócsányi 2014a, p. 79.
} 
(iii) és mely szerv vagy szervek határozhatják meg az alkotmányos identitás tartalmát? ${ }^{394}$

Ahogy azt Sulyok összefoglalja - többek között Besselinkre utalással -, két álláspont verseng egymással: A szupranacionális/integrista nézőpont, amely az identitás-klauzula értelmezését az EUB-hez telepíti - amely azonban azt eredményezné, hogy a Bíróság lényegében a tagállamok alkotmányának értelmezését végezné el, ilyen az Alapító Szerződésekből fakadó felhatalmazással viszont nem rendelkezik. Többek között ezért is lesz meghatározó jelentőségü az EUB, már idézett C-357/19. sz. ügyben majd a jövőben megszülető döntése. Ha az EUB kimondja az ott feltett előzetes kérdésben, hogy a nemzeti alkotmányértelmező erga omnes hatályú döntésével szemben is alkalmazni kell az uniós jogot, azzal önmagát - ugyan közvetett módon - a tagállami alkotmányok fölé helyezi.

A másik megközelítés a „szuverenista” nézőpont, amely a tagállami alkotmánybíróságokhoz utalja a kérdés eldöntését. ${ }^{395}$ Ennek a megközelítésnek a megnyilvánulása a német PSPP döntés, ahol a Német Szövetségi Alkotmánybíróság a Szerződések szellemiségéből (Integrationsprogramm - lásd később) kiindulva kinyilvánította az EUB döntésének alkalmazhatatlanságát és az EKB PSPP programjának alkotmányellenességét.

Idézett tanulmányában Sulyok, a tagállami alkotmánybíróságok Lisszabon-határozatait elemezve vizsgálja az egyes tagállamok alkotmányos identitásról kialakított gyakorlatát, amely vizsgálatot a továbbiakban magam is irányadónak tekintek. ${ }^{396}$ Valamelyest eltekintve az uniós jog perspektívájától, érdemes visszatérni ezen a ponton az értekezés első fő részében az identitás fogalmáról, illetve az alkotmányos identitásról mondottakhoz, ahol az identitást, mint az önmagáról gondolkodó szubjektum (alkotmányos identitás esetén az alkotmányos alany) önmeghatározását definiáltuk. Ez alapján ugyanis az identitás elsősorban önmeghatározás, amelyet az önmagáról gondolkodó szubjektum ugyan szükségszerüen a vele kapcsolatban álló más szubjektumokra - és a fennálló viszonyrendszerre - tekintettel, de mégis szükségképpen

\footnotetext{
394 Vö. Besselink 2010, p. 42.

395 Bővebben ld. Sulyok 2014a, p. 10.

396 Vö. Sulyok 2014a, Drinóczi 2017 b
} 
önmaga alakít ki. Folytatva a gondolatot a kollektív identitás kialakításánál írtakkal, a kollektív identitás csak visszahathat az őt létrehozó szubjektumok identitására létrehozva a kölcsönösen formáló mechanizmust -, de azt oktrojált formában nem határozhatja meg. Hiszen, ha egy identitást formáló szubjektum lemond identitásának formálásáról, elkezdődik egyfajta asszimiláció, vagyis a szubjektum megszünik „önmagának lenni”.

Következésképpen, mivel az integráció tekintetében az alkotmányos identitást hordozó szubjektumok a tagállamok, egy adott tagállam kizárólag - szükségszerúen a kollektív identitásra, vagyis az integrációra tekintettel - önmaga határozhatja meg saját (alkotmányos) identitását. Ellenkező esetben fennáll annak a veszélye, hogy a kollektív identitás természetellenes dominanciája következtében megbomlik a kollektívát esetünkben a szupranacionális rendszert - összetartó kohéziós erő, mivel a kollektívát alkotó szubjektumok nem képesek azonosulni a kollektív identitással és így nem fogadják be azt (vö. a természetes alkotmányok korszakánál írtakkal).

Az uniós jogrendre vetítve mindezt, kizárólag a tagállamok együttes, kifejezett akarata következtében alakulhat ki az EUB olyan dominanciája, amely a nemzeti alkotmányértelmező testületek döntését háttérbe szorítja. Ellenkező joggyakorlat kialakításával az EUB az integrációs jogrend védelme érdekében hozott döntésével az integráció stabilitását összetartó bizalmat sodorhatja veszélybe. Ezért részben kiegészítéssel - egyetértek Sulyok és Besselink fentebb hivatkozott azon álláspontjával, amely szerint az alkotmányos identitás tartalommal való kitöltésére a tagállamok (pontosabban azok autentikus alkotmányértelmező szervei) hivatottak. Mivel azonban nem lehetséges a kérdést csak az EUB, vagy csak a tagállami alkotmánybíróságok javára eldönteni, talán helyesebb az a megfogalmazás, amely szerint a tagállamok alkotmányos identitása nem határozható meg a tagállami alkotmányértelmező szervek ellenében.

Az EUB joggyakorlata ${ }^{397}$ a német PSPP döntésig nem került feloldhatatlan kollízióba a tagállami alkotmányértelmezők gyakorlatával, ez azonban 2020. május 5-én

\footnotetext{
397 Különösen is: Angelo Alberto Torresi (C-58/13) és Pierfrancesco Torresi (C-59/13) vs. Consiglio dell'Ordine degli Avvocati di Macerata ügy és C-208/09 Ilonka Sayn-Wittgenstein vs. Landeshauptmann von Wien ügy, C-399/11 Melloni és a már hivatkozott C-213/07 Michaniki ügy, Taricco és társai (C-105/14. sz.). Az EUB vonatkozó joggyakorlatának teljeskörü feldolgozáát lásd: Orbán 2020, pp. 112194.
} 
megváltozott. Igaz, hogy az összeütközés gyújtópontjában nem az alkotmányos identitás sérelme, hanem a német alaptörvényt sértő ultra vires uniós aktusok állnak, kiegészülve ugyanakkor az alkotmányos identitás sérelmével. Ezzel - a feltehetően precedens jellegü - döntéssel az EUB és a tagállami alkotmánybíróságok közötti kapcsolat meghatározásának fentebb kifejtett problémája az alkotmánybíróságok integrációs szerepét megerősítő irányába látszik elmozdulni. A PSPP döntés azonban valószínűleg kinyitotta Pandóra szelencéjét és nem marad válasz, illetve következmények nélkül.

A román legfelsőbb bíróság által benyújtott C-357/19. számon fentebb is említett előzetes döntéshozatali kérdés megválaszolása például egy olyan lehetőséget teremthet az EUB számára, ahol „válaszolhat” a német alkotmánybíróság határozatában foglaltakra, azonban jelen pillanatban a vita fejlődésének iránya álláspontom szerint megjósolhatatlan. Az EUB feltehetően a jövőben sem hivatkozik majd expressis verbis az alkotmányos identitásra (EUSZ alkalmazásában nemzeti identitás), illetve az EUSZ 4. cikk (2) bekezdésére, a vita súlypontja vélhetően egyre inkább eltolódik majd az ultra vires aktusok irányába. 


\subsection{Egy új korszak hajnalán? Alkotmányos identitás és az ultra vires aktusok a Német Szövetségi Alkotmánybíróság PSPP döntésének tükrében ${ }^{398}$}

A korábban kifejtettek szerint, az alkotmányjog európai dimenzióiról folytatott diskurzus során meghatározó terület az EUB és a nemzeti alkotmánybíróságok közötti kapcsolat ${ }^{399}$, hiszen előbbi az uniós jog, míg utóbbi a nemzeti alkotmányok autentikus, erga omnes hatályú értelmezője. ${ }^{400}$ A testületek közötti reláció kérdése azonban már önmagában is csak következmény: az uniós jog és a nemzeti alkotmányok viszonyának látszólag szabályozott ${ }^{401}$, a felszín alatt azonban törékeny egyensúlyi állapoton alapuló kapcsolata. ${ }^{402}$ Az uniós jog elsőbbségének elve a tagállami alkotmányokkal szemben nem az Alapító Szerződésekben expressis verbis lefektetett klauzula: az EUB munkálta ki a van Gend en Loos, majd a Costa vs. E.N.E.L. döntésekben. ${ }^{403}$ A korábban már hivatkozottak szerint az EUB gyakorlata azonban nem kapott fenntartás nélküli támogatást a tagállamok részéről. Az 1970-es évektől kezdődően a német Szövetségi Alkotmánybíróság a már hivatkozott Solange döntésekkel kinyilvánította, hogy meghatározott feltételek teljesülése esetén fenntartja magának a jogot arra, hogy mellőzze az uniós jog alkalmazását a német alaptörvénnyel szemben. ${ }^{404}$

A Szövetségi Alkotmánybíróság elvi jellegü megállapításai azonban sohasem váltak valósággá: a testület az alapjogi fenntartás és az ultra vires tesztjének megalkotása óta egyszer sem helyezkedett olyan álláspontra, amely a Solange döntésekben megfogalmazottak alkalmazását jelentette volna. ${ }^{405} \mathrm{Az}$ évtizedek alatt az unió értékközösségé válásával és a belső feszültségek erősödésével az uniós jog és a nemzeti alkotmányok közötti esetleges összeütközés látszólag elméleti és az utóbbi évtizedben egyre inkább politikai jellegü vitává formálódott, ami hipotetikus jellegével mind jobban az euroszkepticizmus egyik jelképévé vált. Az uniós jog abszolút elsőbbsége a nemzeti alkotmányokkal szemben doktrínává szilárdult. Az alkotmányos paradoxon által életre

\footnotetext{
398 Jelen fejezet az Európai Tükör 2020/2. számában megjelenő, jelenleg közlésre befogadott, Sulyok Mártonnal társszerzésben készített „A gazda bekeríti házát”? A Német Szövetségi Alkotmánybíróság PSPP döntésének jelentősége és az európai integrációért viselt alkotmányos felelősség realitása" c. tanulmányhoz készített kutatás alapján készült. A döntés vizsgálatát valamelyest más megközelítésből Chronowski Nóra szintén elvégzi, amely elemzésre a fejezet elkészítése során szintén támaszkodtam. Vö.: Chronowski 2020. 399 Vö.: Várnay 2019, pp. 63-91., Szakály 2015, p. 35.

${ }^{400}$ Vincze-Chronowski 2018, pp. 493-515.

${ }^{401}$ Belov 2017, pp. 72-97.

402 Trócsányi 2014b, pp. 473-476.

${ }^{403}$ Blutman 2013, pp. 366-377.

${ }^{404}$ Vö: BVerfGE 37, 271 - Solange I., BVerfGE 73, 339 -Solange II.

${ }^{405}$ Vö.: Vincze-Chronowski 2018, pp. 197-218.
} 
hívott rendszerbe azonban kódolva van az destabilizálódás veszélye: egy hallgatólagosan elfogadott, fenntartásokkal kezelt szabályra épül, az uniós jog abszolút, kivétel nélküli primátusának integrációs igényével.

A nemzeti alkotmánybíróságok és az EUB kapcsolatát, illetve az uniós jog abszolút primátusát a tagállami alkotmányok felett az alkotmányértelmező testületek az európai alkotmányos párbeszéd ${ }^{406}$ eszközével igyekeztek és igyekeznek a mai napig a fenntarthatóság medrén belül tartani, míg az e relációk meghatározása iránti igény idő közben életre hívta az alkotmányos identitás védelmének szükségességét. ${ }^{407}$ Az elmúlt évek tudományos diskurzusában mind többször találkozhattunk a nyilt kenyértörés pillanatával, mikor a két testület közötti viszony meghatározatlanságából fakadóan a testületek és az általuk védelmezett jogforrások összeütköznek. 2020. május 5-én úgy tünik, hogy a Német Szövetségi Alkotmánybíróság PSPP ${ }^{408}$ tárgyában hozott döntésével ${ }^{409}$ a nyilt kenyértörés pillanata elérkezett, bár talán kevésbé lesznek hevesek az ezt követő folyamatok, mint azt elsőre gondolnánk. A Szövetségi Alkotmánybíróság döntése azonban nem előzmény nélküli: az EUB döntésének ultra vires nyilvánítását és alkalmazásának mellőzését előzetes döntéshozatali eljárás előzte meg.

\footnotetext{
${ }^{406}$ Vö.: 22/2016. (XII. 5.) AB határozat, AB 2016, 1418, 33- 34. pont, 45-46. pont, 76. pont. Stumpf 2018, pp. 46-51., Drinóczi 2017a, pp. 86-161.

407 Vö.: Orbán 2018

408 https://www.ecb.europa.eu/mopo/implement/omt/html/pspp.en.html (2020.05.22.)

4092 BvR 859/15 -, paras. (1-237),
} 


\subsubsection{Előzmények}

A német Szövetségi Alkotmánybíráság az EUMSZ 267. cikk alapján nyújtott be előzetes döntéshozatal iránti kérelmet az EUB-hez 2017. augusztus 17-én az elötte folyamatban lévő alkotmányjogi panaszeljárás keretében. ${ }^{410} \mathrm{~A}$ panaszosok az EKB kötvényfelvásárlási programjával összefüggő határozatait támadták ${ }^{411}$, tekintettel azok ultra vires jellegére, amelynek következtében álláspontjuk szerint a Német Szövetségi Banknak, a Szövetségi Kormánynak, illetve az Alsóház (Bundestag) azok végrehajtásában történő közreműködése - utóbbi kettő esetén mulasztás útján - ellentétes az Alaptörvénnyel. ${ }^{412}$ A panaszosok szerint az EKB határozatai együttesen ultra vires jogi aktust képeznek, megsértik az EUMSZ 119. cikkében rögzített hatáskörmegosztás elvét, tekintettel arra, hogy azok nem tartoznak az EKB hatáskörébe, amelyet az EUMSZ 127. cikk (1) és (2) bekezdése, valamint a Központi Bankok Európai Rendszere és az Európai Központi Bank alapokmányáról szóló jegyzőkönyv 17-24. cikke határoz meg. ${ }^{413}$ A panaszosok előadták továbbá, hogy az EKB határozatai sértik az EUMSZ 123. cikkét, illetve a német Alaptörvényben rögzített demokrácia követelményét és ezáltal a német alkotmányos identitást. ${ }^{414}$

A panaszosok által előterjesztett indítványokra tekintettel a Szövetségi Alkotmánybíróság az alábbi kérdésekben fordult az EUB-hez:

(i) Ellentétesek-e az EKB határozatai, a határozatok végrehajtásának módja, illetve a PSPP rendszer végrehajtásának egyes elemei az EUMSZ 123. cikkének (1) bekezdésével? ${ }^{415}$

(ii) Ellentétesek-e ezen határozatok az EUMSZ 123. cikkével akkor, ha annak további végrehajtása a pénzügyi piacok megváltozott körülményeire tekintettel az eredetileg alkalmazandó vásárlási szabályok folyamatos lazítását

\footnotetext{
${ }^{410}$ A testülethez érkezett alkotmányjogi panaszok az EKB 2014 óta zajló kötvényfelvásárlási programjának alkotmányossági felülvizsgálatát kérték a testülettől a Szövetségi Kormány és a Bundestag felelősségén keresztül. Vö.: 2 BvR 859/15, 12-63. pont

${ }^{411}$ Jelen értekezésnek nem célja a PSPP program és az EKB döntéseinek közgazdaságtani, illetve célszerűségi vizsgálata. Az alapügyben támadott határozatokat bővebben lásd: C-493/17. sz. ügy, 3-12. pont

412 C-493/17. sz. ügy, 13. pont

413 C-493/17. sz. ügy, 14. pont

414 Uo.

${ }^{415}$ C-493/17. sz. ügy, 16/1. pont
} 
igényli, vagyis gyakorlatilag a folyamatos többletkötelezettséget ró(hat) a részes tagállamok költségvetésére? ${ }^{416}$

(iii) Ellentétes-e az EKB 2015/774. sz. határozata az EUMSZ 119. cikkel és az EUMSZ 127. cikk (1) és (2) bekezdésével, valamint a KBER-ről és az EKB-ról szóló jegyzőkönyv 17-24. cikkével azért, mert az túllép az EKB e rendelkezésekben szabályozott monetáris politikai hatáskörén, és ezért beavatkozik a tagállamok (gazdaságpolitikai) hatáskörébe? ${ }^{417}$

(iv) Az EKB hatáskörének túllépését jelenti-e különösen az, hogy

- $\quad$ az első kérdésben említett határozatok a PSPP - 2017. május 12-én 1534,8 milliárd eurós - volumene folytán nagymértékben befolyásolja a tagállamok refinanszírozási feltételeit?

- az első kérdésben említett határozatok által testet öltő PSPP program a tagállamokra nézve nemcsak közvetett gazdaságpolitikai következményekkel jár, hanem a monetáris politikai célkitűzés mellett azzal legalább egyenrangú gazdaságpolitikai célkitüzéssel is rendelkezik?

- az első kérdésben említett határozatok azok erőteljes gazdaságpolitikai hatásai miatt sértik az arányosság elvét?

- az első kérdésben említett határozatok részletes indokolás hiányában a több mint két évig tartó végrehajtás során nem vizsgálhatók felül abból a szempontból, hogy azok továbbra is szükségesek és arányosak-e? ${ }^{418}$

(v) Ellentétes-e a PSPP program az EUMSZ 119. cikkel és az EUMSZ 127. cikk (1) és (2) bekezdésével, valamint a KBER-röl és az EKB-ról szóló jegyzökönyv 17-24. cikkével azért, mert annak volumene és több mint két évig tartó végrehajtása, valamint az ebből eredő gazdaságpolitikai hatások a PSPP szükségességének és arányosságának eltérő megítélését teszik indokolttá, és a határozat emiatt egy meghatározott időponttól az EKB monetáris politikai hatáskörének túllépését jelenti? ${ }^{419}$

(vi) Ellentétes-e az első kérdésben említett határozatban a központi kormányzatok és a velük egyenrangú kibocsátók kötvényeinél felmerülő veszteségek tekintetében az eurórendszerbeli nemzeti központi bankok között alkalmasint

${ }^{416}$ C-493/17. sz. ügy, 16/2. pont

${ }^{417}$ C-493/17. sz. ügy, 16/3. pont

${ }^{418}$ C-493/17. sz. ügy, $16 / 3$. pont

${ }^{419}$ C-493/17. sz. ügy, 16/4. pont 
alkalmazott korlátlan kockázatmegosztás az EUMSZ 123. és EUMSZ 125. cikkel, valamint az EUSZ 4. cikk (2) bekezdésével, ha ez a nemzeti központi bankok költségvetési forrásokból történő feltőkésítését teheti szükségessé? ${ }^{420}$

Az EUB döntésében lényegében valamennyi, a Szövetségi Alkotmánybíróság által feltett kérdésben az EKB határozatainak javára döntötte el a kérdéseket. Nem látta megalapozottnak az EKB döntéseiben sem a megfelelö indokolás hiányát, sem az arányosság elvének túllépését, és így az ultra vires jelleget, az alkotmányos identitásra történő hivatkozást -az EUSZ 4. cikk (2) bekezdés - pedig gyakorlatilag figyelmen kívül hagyta.

A PSPP program szükségességének indokolásával kapcsolatban az EUB megállapította, hogy amikor olyan általánosan alkalmazandó jogi aktusról van szó, amelyből kitünik az uniós intézmény által elérni kívánt cél lényege, nem lehet külön indokolást megkövetelni az intézménytől minden egyes alkalmazott technikai megoldás esetében. ${ }^{421}$ Az EUB álláspontja szerint a PSPP és az annak alapjául szolgáló EKB határozatok esetében a határozatok indokolását az EKB különböző, a határozatoktól elkülönült dokumentumokon (így különösen elemzéseken, kimutatásokon) keresztül tette közzé, amelyek tartalmazták az EKB Kormányzótanácsa által fontolóra vett különféle lehetőségeket, valamint „, a meghozott döntéseket alátámasztó okokat, különös tekintettel a PSPP megfigyelt és várható hatásaira. " 422

Az EUB hivatkozik továbbá az indokolási kötelezettséggel összefüggésben arra, hogy a kötvényvásárlási programra vonatkozóan az EKB elnöke rendszeresen sajtóközleményeket tett közzé, illetve sajtótájékoztatók keretében megválaszolásra kerültek a felmerülő kérdések, illetve elérhetőek az EKB Kormányzótanácsa monetáris politikai üléseinek jegyzőkönyvei is, amelyek tartalmazzák a Kormányzótanácson belül zajló vitákat a PSPP-vel összefüggésben. ${ }^{423} \mathrm{Az}$ EUB szerint ,,mindezen tényállási elemböl az következik, hogy a KBER magyarázatot adott arra, hogy az infláció tartósan elégtelen szintje és a monetáris politikájának gyakorlásához hagyományosan használt

${ }^{420} \mathrm{C}-493 / 17$. sz. ügy, $16 / 5$. pont

${ }^{421}$ C-493/17. sz. ügy, 32. pont

${ }^{422}$ C-493/17. sz. ügy, 36. pont

${ }^{423}$ C-493/17. sz. ügy, 37. pont 
eszközök kimeritése alapján miért is tartotta szükségesnek egy olyan kötvényvásárlási program elfogadását, majd bevezetését 2015-töl kezdödöen, amely mind az alapelvét, mind pedig az egyes részletszabályait illetöen a PSPP jellemzöit mutatja "424 és ,,ezek a tényállási elemek arra engednek következtetni, hogy az EKB kellöképpen megindokolta a 2015/774 határozatot”, 425 amelyre tekintettel ,, a 2015/774 határozat kapcsán nem merül fel olyan indokolási hiányosság, amely e határozat érvénytelenségét eredményezné." 426

A Szövetségi Alkotmánybíróság hatásköri aggályaival összefüggő kérdésekkel kapcsolatban az EUB hasonlóan az indokolási kötelezettséghez, elutasító álláspontra helyezkedett. (A későbbiek során részletesen tárgyalt PSPP döntés megszületésének egyik központi eleme a testület azon meggyőződése, hogy az EUB az előzetes döntéshozatali eljárás során hiányosan vizsgálta, illetve válaszolta meg a Szövetségi Alkotmánybíróság által feltett kérdéseket különös tekintettel az arányosság követelményére.) A Szövetségi Alkotmánybíróság által feltett (fentebb v. sz. alatt jelzett) kérdés alapján az EUB-nek arra kellett választ adnia, hogy a 2015/774. sz. határozatban foglaltak meghozatalára a KBER rendelkezik-e megfelelő, az elsődleges jogból fakadó hatáskörrel, különös tekintettel a határozat hosszútávú hatásaira, amelyek a PSPP keretében megvásárolható kötvények mennyiségéből és annak időtartamából erednek.

Az EUB a kérdés megválaszolása során az EUMSZ 119. cikk (2) bekezdéséből indult ki, azaz abból a tényből, hogy a tagállamok és az unió tevékenysége magában foglalja az euró bevezetését, amely egységes monetáris és árfolyampolitikát tesz szükségessé. ${ }^{427} \mathrm{Az}$ EUB hivatkozott arra, hogy az EUMSZ 3. cikk (1) bekezdésének c) pontja alapján az unió kizárólagos hatáskörrel rendelkezik a monetáris politika területén azon tagállamok tekintetében, amelyek pénzneme az euró, ${ }^{428}$ illetve az EUMSZ 282. cikk (1) bekezdése értelmében az unió monetáris politikáját az EKB, és azon tagállamok központi bankjai irányítják, amelyek pénzneme az euró, és amelyek az eurórendszert alkotják. ${ }^{429}$ Ennek keretében az EUMSZ 127. cikk (2) bekezdése, az EUMSZ 130. cikk és az EUMSZ 282. cikk (4) bekezdése alapján a KBER feladata az euróövezeti monetáris politika ,, független meghatározása és végrehajtása, tiszteletben tartva a hatáskör-átruházás elvét, amelyet

\footnotetext{
${ }^{424}$ C-493/17. sz. ügy, 41. pont

${ }^{425}$ C-493/17. sz. ügy, 42. pont

${ }^{426}$ C-493/17. sz. ügy, 44. pont

${ }^{427}$ C-493/17. sz. ügy, 46. pont

${ }^{428}$ C-493/17. sz. ügy, 47. pont

${ }^{429}$ C-493/17. sz. ügy, 48. pont
} 
bírósági felülvizsgálata révén - a Szerzödésekben meghatározott feltételekkel - a Bíróságnak kell biztosítania. ”430 A Bíróság - miután gyakorlatilag megállapította saját hatáskörét ennek kimondására - kimondta, hogy az EUM-Szerződés nem tartalmazza a monetáris politika pontos meghatározását, ,, viszont meghatározza a monetáris politika célkitüzéseit és e politika végrehajtása érdekében a KBER rendelkezésére álló eszközöket." ${ }^{431}$ Az EUB az EUMSZ idézett rendelkezéseinek értelmezéséből arra a következtetésre jutott, hogy a „Szerzödések alkotói amellett döntöttek, hogy az Unió monetáris politikájának elsödleges célját, nevezetesen az árstabilitás fenntartását, általános és elvont módon határozzák meg, annak pontos megállapítása nélkül, hogy milyen módon kell számszerüen konkretizálni e célkitüzést. "432

Az EUB tehát a fentiek alapján úgy ítélte meg, hogy a PSPP program az euróövezeti monetáris politika meghatározása körében az EKB feladata és ezáltal nem valósul meg a hatáskörtúllépés, illetve nem beszélhetünk ultra vires aktusról. ${ }^{433}$ Az uniós testület tehát lényegében figyelmen kívül hagyta a Szövetségi Alkotmánybíróság azon érvelését, miszerint a PSPP program a monetáris hatásokon kívül gazdaságpolitikai célkitűzésekkel (és hosszú távú következményekkel) is rendelkezik, amelynek meghatározása pedig már a tagállami szuverenitásból fakadó, át nem ruházott tagállami hatáskör ${ }^{434}$ és a szövetségi alkotmánybíróság gyakorlata szerint az alkotmányos identitás által védett körbe tartozik. $^{435}$

A hatásköri problematikát követően az EUB az arányosság uniós jogi követelményét vizsgálta, amelyben a hatásköri kérdésekhez hasonlóan sem azonosította az uniós jog sérelmét. ${ }^{436} \mathrm{Az}$ arányosság vizsgálata során az EUB kifejtette, hogy az arányosság elve a Bíróság állandó ítélkezési gyakorlata szerint megköveteli, hogy „az uniós intézmények aktusai alkalmasak legyenek az érintett szabályozással kitüzött jogszerü célok megvalósitására, és ne menjenek túl az azok eléréséhez szükséges mértéken. ${ }^{437}$ Ennek keretében az EUB gyakorlatilag azt mondta ki, hogy a PSPP összetett, kockázati tényezőt

\footnotetext{
${ }^{430}$ C-493/17. sz. ügy, 49. pont

${ }^{431}$ C-493/17. sz. ügy, 50. pont

${ }^{432} \mathrm{C}-493 / 17$. sz. ügy, 55. pont

${ }^{433}$ C-493/17. sz. ügy, 70. pont

${ }^{434}$ Vö.: C-493/17. sz. ügy, 16. pont

4352 BvR 859/15, 1. pont

436 Vö.: C-493/17. sz. ügy, 70-100. pont

${ }^{437}$ C-493/17. sz. ügy, 72. pont
} 
magában foglaló jellegére - miután ez a fentiek szerint a monetáris politika keretén belül az EKB hatáskörébe tartozik -, illetve arra tekintettel, hogy e hatáskör keretében az EKBnek „összetett elörejelzéseket és értékeléseket kell végeznie”, ezért „számára széles mérlegelési jogkört kell biztositani. "438

Miután az EUB megállapította, hogy a PSPP rendszere álláspontja szerint az EKB hatáskörébe tartozó rendelkezéseket tartalmaz, illetve a kötvényfelvásárlási program megfelelő eszköz az EKB által meghatározandó monetáris politikai célok eléréséhez, lényegében figyelmen kívül hagyva a Szövetségi Alkotmánybíróság által felhozott érveket - gazdaságpolitikai vonatkozások, veszteségért viselt felelősség, stb. - és akként foglal állást, hogy a PSPP nem sérti az arányosság követelményét sem annak volumenét, sem idejét, sem pedig esetleges következményeit, így különösen a nemzeti jegybankokra háruló - veszteség esetén jelentkező - felelősséget tekintve. ${ }^{439}$

Végül az EUB arra hivatkozással, hogy az hipotetikus jellegü, mellőzte a Szövetségi Alkotmánybíróság utolsó kérdésének megválaszolását, amely a kötvényeknél felmerülő veszteségek tekintetében az eurórendszerbeli, tagállami központi bankok között alkalmazott korlátlan kockázatmegosztás és az EUMSZ 123., EUMSZ 125. cikkek, illetve az EUSZ 4. cikk (2) bekezdése közötti összhangra irányult. ${ }^{440}$ (A kérdés arra az esetre vonatkozott, ha a kockázatmegosztás a tagállami központi bankok költségvetési forrásokból történő feltőkésítését tenné szükségessé.)

\footnotetext{
${ }^{438}$ Vö.: C-493/17. sz. ügy, 75-78. pont

${ }^{439}$ Vö.: C-493/17. sz. ügy, 80-100. pont

${ }^{440}$ Vö.: C-493/17. sz. ügy, 159-167. pont
} 


\subsubsection{A 2020. május 5-i döntés tartalma}

Döntésében a Szövetségi Alkotmánybíróság több, az európai integrációt és az uniós jogrendet meghatározó megállapítást is tett, amelyek azonban csak első olvasatra minősíthetők az „integrációval szembeni” rendelkezéseknek. A testület határozatának genezisét a német alkotmányjogtudományban kimunkált Integrationsverantwortung ${ }^{441}$ képezi, amely a német alkotmányos szervek - így jelen esetben a Szövetségi Kormány, a Bundestag, illetve a Szövetségi Alkotmánybíróság - integrációs folyamatért (Integrationsprogramm ${ }^{442}$ ) viselt felelősségi alakzataként értelmezhető. ${ }^{443} \mathrm{Az}$ alkotmányos szervek integrációs folyamatért viselt felelősségének alapja az Alaptörvény 23. § (1) bekezdése, vagyis a német Alaptörvény integrációs klauzulája. ${ }^{444}$ A Szövetségi Alkotmánybíróság állandó gyakorlata - és a PSPP döntés - szerint a német alkotmányos intézmények az integrációs folyamatért viselt felelősségük körében kötelesek megfelelő lépéseket tenni annak megvalósítása és védelme érdekében. ${ }^{445}$ A Szövetségi Alkotmánybíróság hangsúlyozta ugyanakkor, hogy az Integrationsverantwortung nem olyan egyoldalú eszköz, amely az uniós intézmények döntéseinek korlátlan elfogadását teszi kötelezővé az alkotmányos intézmények számára. Ellenkezőleg: az Integrationsprogramm, vagyis az EUMSZ-ben megfogalmazott integrációs gondolat megvalósításaként értelmezhető és mint ilyen, ennek urai a tagállamok, ${ }^{446}$ amelynek következtében a német alkotmányos szervek felelőssége az uniós szervek rendelkezéseinek betartása és érvényesítése, amennyiben azok az Alapító Szerződésekkel összhangban megfelelnek az Integrationsprogramm gondolatának. Ugyanakkor amennyiben az uniós szervek rendelkezései ellentétesek az ,integrációs gondolattal”, a német alkotmányos szervek integrációért viselt felelőssége megköveteli, hogy fellépjenek

\footnotetext{
441 Tischendorf 2016, pp. 7-9.

442 Vö.: Degenhart 2019

${ }^{443}$ Vö.: Kellermann 2009, pp. 1-6.

444 "A Német Szövetségi Köztársaság az egyesült Európa megvalósitásához hozzájárul az Európai Unió létrehozásán keresztül, melyet a demokratikus, a jogállami, a társadalmi és a föderatív alapelvek, valamint a szubszidiaritás elve köteleznek és az ezen alaptörvény által biztositott jogvédelemhez lényegében hasonló jogvédelmet biztosit. A Szövetség ehhez a Szövetségi Tanács által jóváhagyott törvényen keresztül felségjogokat ruházhat át. Az Európai Unió alapitása, szerzödéses alapjainak megváltoztatása, valamint olyan hasonló szabályok vonatkozásában, melyek ezen alaptörvény tartalmát megváltoztatják vagy kiegészitik, illetve ilyen módositásokat vagy kiegészitéseket lehetővé tesznek, a 79. cikk (2) és (3) bekezdése érvényes." A fordítást lásd: Heka-Jakó-Mikes-Pongó-Szakály 2018, p. 669.

4452 BvR 859/15, 116. pont

4462 BvR 859/15, 53. pont, 89. pont, 105-109. pont
} 
a szerződésekből nem következő, ultra vires aktusokkal szemben, de legalább is megkíséreljék azok káros hatásainak enyhítését. ${ }^{447}$

A Szövetségi Alkotmánybíróság álláspontja szerint - amely megjelent a döntést megelőző előzetes döntéshozatali eljárás indítványában is - az EKB kötvényvásárlási programja túllép az EKB és a KBER hatáskörén, tekintettel arra, hogy annak az eurózónára kiterjedő monetáris politikai hatásain túl gazdaságpolitikai - fiskális következményei, illetve hosszútávú hatásai vannak ${ }^{448}$, amelynek meghatározása azonban kizárólagosan a tagállamok át nem ruházott hatáskörei között tartódnak számon. ${ }^{449} \mathrm{~A}$ testület 2020. május 5-én kelt döntésében (több eljárást - 2 BvR 859/15, 2 BvR 980/16, 2 BvR 2006/15, 2 BvR 1651/15 - egyesítve) megállapította, hogy az EUB a C-493/17. sz. előzetes döntéshozatali eljárásban 2018. december 11-én kelt határozatában az EKB kérdéses határozatainak, illetve a PSPP program hosszútávú gazdaságpolitikai hatásinak érdemi vizsgálata nélkül mondta ki, hogy az EKB határozatai, illetve a PSPP program megfelel az uniós jog - így különösen az arányosság követelményeinek. ${ }^{450}$ Az uniós bíróság vizsgálata a Szövetségi Alkotmánybíróság szerint nem terjedt ki a PSPP valós gazdasági - hosszútávú - hatásainak figyelembevételére, és így azt sem vizsgálta érdemben, hogy az EKB nem lépte-e túl az elsődleges jogból fakadó monetáris hatáskörét. ${ }^{451}$

A Szövetségi Alkotmánybíróság szerint az EUB nem alkalmazta megfelelően az arányossági tesztet ${ }^{452}$, így az EUSZ 5. cikk (1) bekezdésének második mondatában és (4) bekezdésében rögzített arányosság követelménye nem tudta ellátni a tagállamok hatásköreinek védelmét biztosító - és az ultra vires aktusokat megakadályozó funkcióját, kiüresítve ezáltal a hatáskörátruházásnak az EUSZ 5. cikk (1) bekezdés második mondatában és 5. cikk (4) bekezdésében foglalt elvét. ${ }^{453} \mathrm{Az}$, hogy az EUB nem értékelte megfelelően a PSPP gazdaságpolitikai hatásait (illetve azt marginalizálva, kvázi alárendelte az eurózóna monetáris célkitüzéseinek ${ }^{454}$ ) a Szövetségi Alkotmánybíróság

\footnotetext{
4472 BvR 859/15, 89. pont, 105-106. pont, 107. pont, 109. pont, 116. pont, 231. pont

4482 BvR 859/15, 133. pont, 136. pont, 139. pont, 159. pont, 161-162. pont

4492 BvR 859/15, 109. pont, 120. pont, 127. pont, 136. pont

4502 BvR 859/15, rendelkező rész 2. pont, 6. pont, indokolás 81. pont, 116. pont, 119-120. pont, 161-162. pont

4512 BvR 859/15, 116-120. pont, 133. pont

4522 BvR 859/15, 116. pont, 126-128. pont

4532 BvR 859/15, rendelkező rész 6b. pont, 6c. pont indokolás, 116. pont, 119. pont, 123-126. pont

4542 BvR 859/15, 120-122. pont, 161-163. pont
} 
szerint önkényes jogértelmezés ${ }^{455}$, amely lehetővé teszi, hogy az EKB a Szerződések által rá ruházott (monetáris politikai) hatáskörén túllépve járjon el, és végső soron teljesen kivonja tevékenységét a bírói felülvizsgálat lehetősége alól. ${ }^{456}$ Mindez olyan precedensjellegű - gyakorlathoz vezet, amely az uniós intézmények számára - jelen esetben az EKB - lehetővé tenné önnön hatásköreinek megállapítását, illetve bővítését (Kompetenz-Kompetenz), ${ }^{457}$ amely ellentétes az integrációs törekvésekkel (Integrationsprogramm) és az Alapító Szerződések rendelkezéseivel. ${ }^{458}$ A Szövetségi Alkotmánybíróság szerint, mivel az EUB döntése - az arányosság elvének elégtelen vizsgálata következtében, illetve a fenti következményekre tekintettel - nem biztosítja az EKB döntéseinek megfelelő bírói felülvizsgálatát ${ }^{459}$ és ezáltal az uniós intézmények, Alapító Szerződésekből nem következő hatásköreinek bővítését eredményezi, ultra vires jellegü és ezáltal a testület nem tartja magára nézve kötelezőnek az abban foglalt jogértelmezést. ${ }^{460}$

A Szövetségi Alkotmánybíróság indokolása szerint a német alkotmányos szervek - így a Szövetségi Kormány, a Bundesbank és az Alkotmánybíróság - Alaptörvényből fakadó kötelezettsége a demokrácia elvének védelme, amelyet az Alaptörvény 20. és 79. cikke - utóbbi az örökkévalósági klauzula - helyez védelem alá és amely forrása Németország alkotmányos identitásának. ${ }^{461}$ A testület a határozatban kifejti, hogy a német népet szuverenitásából fakadóan megilleti a demokratikus önrendelkezés joga, a demokrácia elvének érvényesülése, amely olyan fundamentális alkotmányos tényező, amelyet az integrációs folyamat sem veszélyeztethet. ${ }^{462}$ A hatáskörök megosztásának rendszere hivatott biztosítani az integrációs folyamat során a demokrácia - és népszuverenitás alapelvének megóvását és ezáltal a demokratikus legitimációt. Ahhoz, hogy az uniós szervek döntései megfelelő demokratikus legitimációval rendelkezzenek, azoknak visszavezethetőnek kell lenni az Alapító Szerződések rendelkezéseire és az azokat létrehozó integrációs gondolatra (Integrationsprogramm). A hatáskörök megosztásának

\footnotetext{
4552 BvR 859/15, 112-113. pont

4562 BvR 859/15, 156. pont

4572 BvR 859/15, 102. pont, 156. pont

4582 BvR 859/15, 102. pont, 105-106. pont, 116. pont

4592 BvR 859/15, 156. pont, 111-113. pont, 116-119. pont

4602 BvR 859/15, 154. pont, 163. pont, 178. pont

4612 BvR 859/15, 115. pont, 230. pont

4622 BvR 859/15, 100-101. pont
} 
stabilitását hivatott biztosítani az arányosság követelménye, amelynek figyelmen kívül hagyása destabilizál(hat)ja a hatáskörök megosztását az unión belül. ${ }^{463}$

A határozat szerint az integrációs gondolat (Integrationsprogramm) nem sérti a népszuverenitás, illetve a demokrácia elvét mindaddig, amíg az uniós intézmények és szervek döntései nem ultra vires jellegüek, azaz az Alapító Szerződésekből fakadó hatáskörök égiszén belül maradnak, amelyet az Európai Unió egyik fö alapelve, a hatáskörátruházás és az azzal szemben támasztott követelmények (és garanciák) hivatottak biztosítani. ${ }^{464}$

A döntés rögzíti, hogy amennyiben az EUB jogértelmezésével nem tartja tiszteletben és túlterjeszkedik az EUSZ 19. cikk (1) bekezdésében meghatározott felhatalmazáson ${ }^{465}$, akkor azzal megsérti az uniós jogi aktusokkal szemben támasztott demokratikus legitimáció minimális követelményét és ezáltal az így meghozott döntés - a fentebb kifejtettekre tekintettel - Németország vonatkozásában nem alkalmazható. ${ }^{466}$ Az EUB az integráció alapgondolatával ellentétes következményekhez vezetö ${ }^{467}$ - elégtelen jogértelmezése és hatáskörtúllépése miatt tehát a Szövetségi Alkotmánybíróság nem tartja maga számára nézve kötelezőnek az EUB előzetes döntéshozatali eljárásban hozott ítéletét és osztja az alkotmányjogi panaszeljárás indítványozóinak azon álláspontját, amely szerint az EKB kötvényfelvásárlási programja elvonja a Bundestag Alaptörvényben rögíztett költségvetési hatáskörét, ami ezáltal sérti a Németország alkotmányos identitását. ${ }^{468}$

A Szövetségi Alkotmánybíróság álláspontja szerint az EKB kötvényfelvásárlási programja vonatkozásában az EUB nem végzett az arányosság elvére kiterjedő, megfelelő mélységü felülvizsgálatot, ${ }^{469}$ amelynek következtében a kérdéses EKB határozatok - és így a PSPP program - tekintetében nem valósul meg a megfelelő bírói kontroll. ${ }^{470}$ A testület szerint a PSPP sérti Németország Alaptörvényét, mert annak egyes

\footnotetext{
4632 BvR 859/15, 101. pont, 158. pont

4642 BvR 859/15, 142. pont, 158. pont

4652 BvR 859/15, 154-156. pont

4662 BvR 859/15, rendelkező rész 2. pont, indokolás 154. pont, 157-158. pont

4672 BvR 859/15, 113. pont, 116. pont

4682 BvR 859/15, 1. pont, 33-42. pont

4692 BvR 859/15, 119. pont, 123. pont, 126. pont

4702 BvR 859/15, 156. pont
} 
rendelkezései, illetve különösen hosszú távú hatásai túlmutatnak a monetáris politikán és a gazdaságpolitika hatókörébe ${ }^{471}$ tartoznak. $^{472}$ Így különösen a kötvényfelvásárlási program kockázatmegosztási rendszere olyan költségvetésre vonatkozó kötelezettségvállalást jelent, amely a Bundestag kompetenciája. ${ }^{473}$ A Szövetségi Alkotmánybíróság egyúttal kifejti a határozatban, hogy a kötvényfelvásárlási program lényegében harmadik fél kötelezettségeiért való helytállást eredményez és ezáltal összeegyeztethetetlen az Alaptörvénnyel, ${ }^{474}$ illetve a testület nem látta igazoltnak azt sem - ellentétben az EUB-vel -, hogy a kötvényvásárlási program megfelel az arányosság uniós követelményének. ${ }^{475}$ A testüket szerint az EKB túllépi az Alapító Szerződésekből fakadó hatáskörét, ha döntéseinek olyan szerteágazó gazdasági vagy társadalompolitikai hatásai vannak, amelyek már a tagállami gazdaságpolitika hatáskörébe tartoznak. ${ }^{476} \mathrm{~A}$ Szövetségi Alkotmánybíróság szerint a kötvényvásárlási program hatással lehet az államadósságra, a magánszféra megtakarításaira, a nyugdíjakra és a nyugdíjrendszerre, az ingatlanárakra és a piacképtelen vállalatok megmentésére. ${ }^{477}$

A Szövetségi Alkotmánybíróság az EKB kötvényfelvásárlási programjának (illetve az azok alapjául szolgáló határozatok), valamint az EUB előzetes döntéshozatali eljárásban született határozatának ultra vires nyilvánításán túl, többek között a német alkotmányos szervek integrációs felelősségére (Integrationsverantwortung), a demokrácia és népszuverenitás elvére (GG 20. cikk) tekintettel az Alaptörvénnyel ellentétesnek ítélte azt, hogy a Szövetségi Kormány és az Alsóház nem támadta meg az EKB kötvényfelvásárlási programjának alapját jelentő határozatokat, amelyekben az EKB érdemben nem vizsgálta és nem is értékelte, hogy a kötvényvásárlási program megfelele az arányosság követelményének. ${ }^{478}$

A Szövetségi Alkotmánybíróság felhívta a Szövetségi Kormányt és az Alsóházat, hogy integrációs felelösségük keretében akadályozzák meg, hogy egy uniós szerv - jelen

\footnotetext{
${ }^{471}$ A gazdaságpolitika összefoglalóan tartalmazza a fiskális és monetáris politikát. Előbbi a kormányzat hatásköre, míg utóbbi szokásosan jegybanki kompetencia, amely az eurozóna esetében speciális és részben az EKB, illetve a KBER hatáskörébe tartozik. Vö.: Blutman 2013, pp. 137-143.

4722 BvR 859/15, rendelkezö rész 6b. pont, indokolás 122. pont, 133. pont, 135. pont, 138-139. pont, 163. pont, 165. pont

${ }^{473} 2$ BvR 859/15, rendelkező rész 8. pont, indokolás 116. pont

${ }^{474} 2$ BvR 859/15, rendelkező rész 8. pont, indokolás 227. pont

4752 BvR 859/15, 167. pont, 176. pont, 178. pont, 185. pont

4762 BvR 859/15, rendelkezö rész 6c. pont, indokolás 139. pont

4772 BvR 859/15, rendelkezö rész 6c. pont, indokolás 139. pont

${ }^{478} 2$ BvR 859/15, rendelkezö rész 6a - 10. pont, indokolás 232. pont
} 
esetben az EKB - a hatáskörét túllépve hozzon a költségvetést (és így a német alkotmányos identitást) érintő döntést. A határozatban a testület felhívta a Szövetségi Kormányt és az Alsóházat, hogy követeljenek meg egy átfogó arányossági vizsgálatot a PSPP-vel összefüggésben, illetve integrációs felelősségükből fakadóan kísérjék figyelemmel, hogy a program az Alapító Szerződésekben meghatározott hatáskörökön belül maradva, ne sérthesse a német alkotmányos identitást és a tagállami hatásköröket. ${ }^{479}$

A határozat több pontban kijelenti, hogy az ultra vires aktusok nem rendelkeznek kötelező erővel - a fentiekre tekintettel - a német közjogi szerveket illetően, azonban a határozat rendelkező részének 10. pontjában, illetve az indokolás 235. pontjában rögzített rendelkezés folytán a Szövetségi Bank csak akkor vehet részt a továbbiakban a PSPP programban, ha az EKB elvégzi a megfelelő arányossági elemzést a kötvényvásárlási program gazdaságpolitikai hatásairól. A Szövetségi Alkotmánybíróság kötelezte továbbá a Szövetségi Bankot, hogy a PSPP keretében már megvásárolt eszközöket bocsássa piacra. $^{480}$

4792 BvR 859/15, 230-232. pont, 234-235. pont

${ }^{480} 2$ BvR 859/15, 235. pont 


\subsubsection{Következmények}

A PSPP döntésben a Német Szövetségi Alkotmánybíróság tehát egy konkrét esetben ezúttal már nem elvi éllel - mondta ki, hogy a német alkotmányos és közigazgatási szervek nem müködhetnek közre az uniós intézmények hatáskört túllépő, ultra vires aktusainak végrehajtásában és egyúttal, először az európai integráció történelmében, az EUB - mint uniós intézmény - egy konkrét határozatáról is kimondta, hogy az ultra vires és ezért azt nem alkalmazza.

A Szövetségi Alkotmánybíróság határozatában tehát egyrészről az EKB PSPP programjának alapjául szolgáló határozatáról, másrészröl az EUB egy konkrét döntéséröl nyilvánította ki azok ultra vires jellegét és azt, hogy erre tekintettel mellőzi azok alkalmazását. A határozat közzétételét követően számos vélekedés látott napvilágot, amely az integráció alkotmányos válságának elmélyülését, az uniós jog elsőbbségének megtörését, vagy éppen az euroszkeptikus törekvések elöretörését látják bele a határozatba. ${ }^{481}$ Fontos azonban hangsúlyozni, hogy a Szövetségi Alkotmánybíróság döntésének fundamentumát két, a német alkotmányjogi gondolkodásban meghonosodott fogalom, az Integrationsverantwortung, mint az integrációs folyamatért viselt alkotmányos felelősség és az Integrationsprogramm, mint az Alapító Szerződésekben testet öltő integrációs gondolat alkotja. A Szövetségi Alkotmánybíróság a döntését egy koherens, számos elemből álló gyakorlatra építve hozta meg, amelynek éppúgy részei a számos alkalommal idézett Solange döntések, mint a 2016-ban született OMT döntés, ${ }^{482}$ illetve a testület alkotmányos identitásra vonatkozó mostanra állandónak nevezhető gyakorlata.

Fontos hangsúlyozni, hogy a döntés az integrációs folyamat érdekében és nem azzal szemben született. A Szövetségi Alkotmánybíróság a határozatban kiemelte, hogy az integrációs folyamat akkor maradhat egy stabil pályán és érheti el az eredetileg kitüzött integrációs célokat, ha nem lép ki az Alapító Szerződések által kijelölt mederből. Jelen esetben az európai integráció az Alapító Szerződésekben élő integrációs gondolat által meghatározott kereten túli dimenzióban kíván(t) a tagállam(ok)ra vonatkozó irányt

481 https://verfassungsblog.de/national-courts-cannot-override-cjeu-judgments/

482 BvR 2728/13 
meghatározni, azonban a „Szerződések uraiként” a tagállamok - a Szövetségi Alkotmánybíróság döntéséből (is) kiolvashatóan - az uniós jogból fakakadó jogosultságuk (és kötelezettségük!) következtében felléphetnek az ilyen irányú, integrációs alapgondolaton túli integrációs folyamatokkal szemben.

Talán korai lenne ezen a ponton messze menö következtetéseket levonni, azonban az elmondható, hogy a tagállami alkotmánybíróságok és az EUB közötti „hatásköri” összeütközés - amely inkább gordiuszi csomó - régóta fennálló vitájában meghatározó mérföldkövet jelent a német Szövetségi Alkotmánybíróság május 5-i döntése, amely rá világít arra, hogy természetesen az uniós jog elsőbbsége továbbra is a megfelelő kritériumok mellett evidencia, az uniós intézmények - és ebben a körben ezúttal az EUB is értendő - sem rendelkeznek korlátlan mérlegelési jogkörrel a tagállamokkal szemben. A német alkotmánybíróság döntése talán a fékek és ellensúlyok elvének egy speciális, integrációs alakzatához vezet, amelynek megjelenésében ez a döntés lehet az első stáció.

Az alkotmányos identitás tükrében vizsgálva a határozatot, nem meglepö fordulat, hogy éppen a német alkotmánybíróság nyilvánított ilyen markáns véleményt az EUB-vel szemben, hiszen már a Solange döntésektől kezdődően a testület vindikálta magának a jogot és fenntartotta a lehetőséget, hogy a Német Alaptörvény védelmében fellépjen az EUB-vel szemben. Ezt a célt szolgálta az alapjogi fenntartás és valamilyen szinten maga az alkotmányos identitás német gyakorlata is. Valamelyest talán érdekes fordulat azonban, hogy a döntésben az alkotmányos identitás ugyan megjelenik, mégis annak genezisét egy sokkal megfoghatóbb, gyakorlatiasabb probléma: az ultra vires aktus képezi.

Visszautalva jelen értekezés korábbi gondolataihoz, a döntés megerösíti azon álláspontomat, miszerint az alkotmányos identitás nem olyan eszköz, amellyel az EUB és a nemzeti alkotmánybíróságok közötti kapcsolat meghatározható, hiszen annak más a célja és funkciója. A szuverenitásnál írottakra, illetve az EUSZ 4. cikk (2) bekezdés két fordulatának értelmezési lehetőségeire szintén visszautalva, az alkotmányos identitás egyedi, tagállami specifikumok - immanens elemek - védelmét szolgálhatja az európai integráción belül. Az alkotmányos identitás jelenthette volna ugyanakkor azt a gyújtópontot, amely a testületek közötti „hatásköri összeütközés” (már amennyiben hatásköri összeütközésről és nem inkább szuverenitási kérdésről van szó a PSPP 
döntésben) problémáját a középpontba állítja, azonban a PSPP döntés alapján ezt a szerepet - legalább is ezúttal és a német gyakorlatban - az ultra vires tölti be. 


\subsection{Identitásképzés szupranacionális szinten: európai (alkotmányos) identitás?}

A szupranacionális jogrendet - röviden - az identitásképzés egy más megközelítéséből is vizsgálni érdemes. Az eddigiekben a tagállamok alkotmányos identitásának alkalmazhatóságát vizsgáltam, tekintettel a szupranacionális környezetből fakadó sajátosságokra. Az európai integráció azonban létrehozza az identitásképzés egy második szintjét, ahol az identitást hordozó szubjektum - a korábban kialakított modell, illetve Rosenfeld és Habermas elméletei alapján - nem a tagállam, hanem maga a szupranacionális entitás, az integráció. A tagállamok és az integráció közötti konfrontatív viszonyt a tagállamok irányából az alkotmányos identitás külső oldalaként határozhatjuk meg, míg az integráció oldaláról európai identitásként nevesíthetjük.

Az integráció kérdését ez alapján, az identitásképzés szemszögéből kétféleképpen kell megközelítenünk:

(i) egyrészt vizsgálnunk kell az egyes tagállamok alkotmányos identitását, pontosabban azt, hogy a tagállamok alkotmányos identitása hogyan érvényesül(het) az integráción belül;

(ii) illetve vizsgálnunk kell az Európai Unió (kollektív) identitását: alkalmazhatók-e az identitásképzésnél levezetettek, illetve az alkotmányos identitás fogalomrendszere a szupranacionális szinten is? ? $^{483}$

Paczolay az európai identitás és alkotmányosság problémáit az egységes európai „démosz” hiányából eredezteti és megállapítja, hogy az EU egyik alapkérdése, hogy vane alkotmánya és ha igen, az mögött áll-e olyan nép, amely egységes „európai identitással” rendelkezik. ${ }^{484}$

Tekintettel az alkotmányos identitás természetének vizsgálata során tett megállapításokra, álláspontom szerint az alkotmányos identitás szempontjából az EU kapcsán a legfontosabb kérdés az, hogy az integráció kezelhetö-e a korábban kifejtett alkotmányos alanyként, illetve amennyiben igen, úgy az alkotmányos alany fejlődési

483 Antal Attila felveti egy „transznacionális alkotmányos identitás” lehetőségét (Antal 2017), míg Rosenfeld az európai integrációt az alkotmányos identitás szempontjából önálló modellként („európai transznacionális modell”) azonosítja. Vö: Rosenfeld 2010, pp. 172-179.

${ }^{484}$ Vö.: Paczolay 2000 
folyamatában melyik, Rosenfeld által meghatározott állapothoz áll jelenleg közelebb: a „subject” vagy a „self” természetéhez?

Rosenfeld az európai (mint „transznacionális”) modellt - a korábbiak szerint - önálló alkotmányos modellként nevesíti és az EU-ra, mint identitását kereső, formálódó alkotmányos rendszerre tekint, amely „több sebből vérzik ugyan”, mégis képes lehet arra, hogy életképes alkotmányos kereteket teremtsen, kialakítva egy kollektív alkotmányos identitást úgy, hogy az a tagállamok saját alkotmányos berendezkedését, identitását ne sértse. ${ }^{485}$

Ezzel szemben Jacobsohn az európai alkotmányozás kapcsán a következőket írja: „, Vita ebben az esetben is az identitás kérdése körül forgott, és nem annyira arról szólt, hogy a nemzeti szinten túli elveket hogyan lehet a saját történelemmel és kultúrával rendelkezö tagállamok joggyakorlatába beilleszteni, mint inkább arról, hogy hogyan lehet - és egyáltalán szükséges-e - beilleszteni a tagállamok eltérő politikai és jogi kultúráit egy átfogó, nemzetközi kormányzás keretei közé, az új entitás egészére jellemző alkotmányos identitás megteremtésével. "486

Ahhoz, hogy megválaszolhassuk a kérdést, beszélhetünk-e európai alkotmányos identitásról, illetve alkalmazható-e az identitásképzés modellje az Unióra, először arra kell felelnünk, hogy tekinthetö-e alkotmányos alanynak az EU? Hiszen, ha nem beszélhetünk alkotmányos alanyról, akkor alkotmányos identitásról sem. Ha viszont létezik az alkotmányos alany, akkor törvényszerüen identitással is rendelkezik, vagyis beszélhetünk európai alkotmányos identitásról.

A kérdés megválaszolásában nem hagyható figyelmen kívül az Unió és a tagállamok egymással vívott konfrontatív viszonya, amely az EU természetéből fakad. Ismét felhívva az identitás vizsgálata kapcsán levont következtetéseket, az integráció és a tagállamok viszonyát tekintve látható, hogy a tagállamok jelentik a kollektív identitást formáló szubjektumokat, míg az integráció testesíti meg a kollektív identitást hordozó entitást. Vagyis a kollektív identitás léte - annak elnevezésétől függetlenül - nehezen kétségbevonható. Mint már láthattuk, a kollektív identitás a szubjektumok egységes

485 Rosenfeld 2010, p. 172.

${ }^{486}$ Jacobsohn 2013, p. 12. 
akaratából születik, majd elindul egy folyamat, amelyben a szubjektumok kihatnak a kollektív identitásra, amely visszahat a szubjektumokra, kölcsönösen formálva egymást. A kérdés csak az, hogy - hosszú távon - az integráció esetében ennek az identitásformálásnak felfedezhető-e egy olyan íve, amely a további egységesülés, a fejlődés felé halad, vagy egy gyengülő kohéziós erőtér hatókörében kell az európai alkotmányos berendezkedéseket meghatároznunk?

A globális nemzetközi tér az EU tagállamait egymás felé taszítja, vagyis az egységes külső fellépés a tagállamok elemi érdeke. Ezzel szemben azonban jelentkezik az EU-n belül, a tagállamok egyediségének védelméből fakadó széthúzó erő, amely igyekszik szétfeszíteni azt. Ugyanakkor mindez nem befolyásolja a tényt, hogy az EU, természetesen a maga sajátosságaival és a lényegéből eredő specifikumokkal, alkotmányos rendszerként kezelendő. E jellegre utal többek között az EUB Les Verts ítélete is, amelyben az alapító szerződéseket alkotmányos kartának minősítette. ${ }^{487}$

Az alkotmányos identitás szemüvegén át vizsgálva az integrációt úgy vélem ahhoz, hogy megválaszolhassuk az európai alkotmányos identitás létjogosultságának kérdését, az integrációt Jacobsohn, illetve Rosenfeld elméletei, illetve az identitásképzés vizsgálata alapján kell értékelnünk ${ }^{488}$ és azonosítanunk kell azt a három tényezőt (az alkotmányos közösséget, az alkotmányozó hatalmat és az alkotmányt), amelyek szimbiotikus viszonya teremti meg az alkotmányos rendszert. Párhuzamban vizsgálva mindezt a rosenfeldi elmélettel, ezek egyben az alkotmányos alany létének kritériumai is.

Az integráció természetéből fakadó sajátosságok miatt, amelyekre fentebb már utaltam, e fogalmakat a nemzetállami, vagy föderatív berendezkedésekhez képest csak specifikus formában találjuk meg. Nehezíti a vizsgálódást, hogy az EU-n belül, ahogy Möllers fogalmaz: „a jogi és politikai kérdések összeolvadása minden alkotmányelméleti kijelentésnek egyben politikai jelentöséget is kölcsönöz. "489

\footnotetext{
${ }^{487}$ Les Verts versus Parlement européen, C-294/83, Rec. II-1339

488 Jacobsohn 2010, pp. 129-131.

${ }^{489}$ Möllers 2011
} 


\subsubsection{Alkotmányos közösség az Európai Unióban}

Ahogyan azt Paczolay megjegyzi, az integráción belül nincs egységes démosz, tehát nem beszélhetünk egységes európai nemzetről. ${ }^{490}$ Habár e megállapítás igaz, álláspontom szerint mégsem jelenthető ki minden fenntartás nélkül. Eltekintve most az európai nemzeteket összekapcsolni hivatott mechanikus eszközöktől - mint pl. az európai polgárság vagy az európai polgári kezdeményezés közvetlen demokratikus eszköze -, nem hagyhatjuk figyelmen kívül a tényt, miszerint az Unió minden tagállamában népszavazás - vagyis a közvetlen demokrácia - útján döntöttek a csatlakozásról és abban a jól ismert egyetlen esetben - a kilépésről is.

Alkalmazva az identitás-fogalommal kapcsolatban tett megállapításokat, illetve a habermasi és hegeli tételeket, az mondható, hogy a nemzetek - amelyek ezúttal a kollektív identitást létrehozni kívánó egyedi szubjektumokat létrehozó alkotmányos közösségek , közvetlenül döntöttek arról, hogy egységbe kívánnak szerveződni, létre kívánják hozni kollektív identitásukat. Ez a tény önmagában alapot szolgáltathat arra, hogy Európa népeire, mint az egység irányába tartó „egészre” tekinthessünk. Természetesen, mint minden olyan kérdésben, amely összefüggésben áll valamilyen identitással, ezúttal is fontos a kontinuitási tényező. Egy közösség létrejövetele, kiforrottá, vagyis öntudattal rendelkezővé válása hosszú időn át tartó organikus folyamat, amely során a rendszert létrehozó szubjektumok formálják a születendő kollektív identitást, és e kollektív identitás egyszersmind visszahat a szubjektumokra (vagyis Európa népeire). Természetesen az sem zárható ki, hogy a folyamat valamely ponton megszakad, a kohézió megszünik és a kollektív identitás is felbomlik.

Trócsányi a jogállamiság fogalmának elemzése során rávilágított ${ }^{491}$, hogy Európa népei között még e legelemibbnek tünő követelményt is nehéz homogén kritériumrendszer szerint érvényesíteni a nemzetek differentia specificái, vagyis eltérő identitásaik miatt. ${ }^{492}$ Trócsányi e gondolata megfeleltethető Paczolay már idézett kijelentésével, miszerint Európa nem „olvasztótégely”. Így az mondható, hogy az egységesülés folyamata (kollektív identitásformálás, egyben az EU alkotmányos alanyiságának fejlődése)

\footnotetext{
${ }^{490}$ Paczolay Péter démosz helyett démoi-ról értekezik. Vö.: Paczolay 2000.

${ }^{491}$ Vö.: Trócsányi 2014c

${ }^{492}$ Vö.: Varga Zs. 2015, pp. 19-22.
} 
kizárólag a tagállamok elemi különbözőségeinek tiszteletben tartásával, vagyis a tagállamok alkotmányos identitásának sérthetetlenségével valósulhat meg. A jelenség egyfajta „lopakodó föderalizmusnak" 493 is tekinthető, Blutman pedig a „szubföderatív” jelzőt alkalmazza. ${ }^{494}$ Jelen pillanatban tehát európai népei az egység irányába tartanak, azonban még közel sem érték el az egység állapotát.

${ }^{493}$ Pl. Sulyok 2014, p. 46.

${ }^{494}$ Blutman 2013, p. 43. 


\subsubsection{Lehet Európának alkotmánya?}

Mikor feltesszük ezt a kérdést, akarva-akaratlanul az Európai Alkotmányt létrehozó szerződés ${ }^{495}$ tervezete, pontosabban annak bukása juthat eszünkbe. ${ }^{496}$ A sikertelen kísérlet tényéből fakadóan pedig talán adja magát a válasz is: az alkotmányozási kísérlet megbukott, Európának nem lehet - legalábbis materiális értelemben véve ${ }^{497}$ alkotmánya, az Alkotmányszerződés elfogadásának kísérletét vizsgálni 2020-ban pedig még kissé anakronisztikusnak is hathat. Az alkotmányozás (amennyiben elfogadjuk az Alkotmányszerződés tervezetét alkotmánynak, és jelen értekezés szerzője így tesz) kísérletéből azonban fontos következtetéseket vonhatunk le az Európai Unió természetéről, az európai integráció folyamatáról és így - következésképpen - az (alkotmányos) identitásformálás európai dimenziójáról. Az Alkotmányszerződés elfogadásának kísérletét számos szemszögből megközelíthetjük, így különösen formális, illetve eljárásjogi, ${ }^{498}$ politikai, ${ }^{499}$ államelméleti-alkotmányjogi szempontokból. ${ }^{500}$ Jelen értekezés keretében a szükséges mértékig érintem ezek közül valamennyit, de vizsgálódásom fókuszában az (alkotmányos) identitásformálás mechanizmusa áll, így az európai alkotmányozás(i kísérlet) folyamatának részletes vizsgálata nem képezi értekezésem tárgyát. Különös tekintettel arra, hogy ezt a vizsgálatot már számos kiváló müben elvégezték mind hazai, mind nemzetközi szinten. ${ }^{501}$

Az Alkotmányszerződés előkészítésének folyamata 2001. december 15-én vette kezdetét, amikor a tagállamok állam- és kormányföinek döntése alapján, az Unió alapszerződéseinek problémáit megoldandó, egy új integrációs alapdokumentum kidolgozására megalakították az Európai Konventet. ${ }^{502}$ Az Alkotmányszerződés Konvent által elkészített tervezetét - 16 hónappal később - 2004. október 29-én Rómában, az Európai Unió állam- és kormányfői aláírták. A szerződéstervezet hatályba lépéséhez a

\footnotetext{
495 Eredeti megfogalmazásban „,Treaty establishing a Constitutional for Europe”, amelyet a továbbiakban praktikussági szempontokat figyelembe véve Alkotmányszerződésként nevesítek. Vö.: Arató-Lux 2012, p. 179.

496 Az Európai Alkotmányt létrehozó szerződés előkészítéséről, az elfogadás körülményeiről, illetve a ratifikáció kudarcáról és az ezekhez füzött következtetésekröl részletesen lásd: Arató-Lux 2012.

497 Arató-Lux 2012, p. 193.

${ }^{498}$ Arató-Lux 2012, pp. 188-192.

499 Arató-Lux 2012, pp. 184-187.

${ }^{500}$ Arató-Lux 2012, pp. 179-184.

${ }^{501}$ Vö.: Arató-Lux 2012, Angyal 2007, Bogdandy 2005, Podolnjak 2007

502 Arató-Lux 2012, pp. 184-187.
} 
tagállamok saját eljárása keretében történő elfogadására lett volna szükség. A ratifikációs folyamat során 2005 tavaszán előbb a francia, majd a holland népszavazáson az integráció két meghatározó tagállama elutasította az Alkotmányszerződés elfogadását. Igaz ugyan, hogy 16 tagállam ratifikálta az Alkotmányszerződést, a két elutasító eredményü népszavazás gyakorlatilag megpecsételte annak sorsát, az Alkotmányszerződés lekerült a napirendről, azonban gyakorlatilag közel azonos tartalmi egyezőséggel, az alkotmány elnevezést és az egységes szerkezetet nélkülözve létrejött ma ismert formájában az Európai Unió fundamentumát azóta is képező Lisszaboni Szerződés. ${ }^{503}$

Ahogyan arra az alkotmány fogalmánál utaltam, az alkotmányfogalom már önmagában is több értelmü kategória. Milyen értelemben keressük tehát Európa alkotmányát? Jogi értelemben? Ebben az esetben azonosítanunk kell egy megfelelő legitimációval felruházott alkotmányozó szervet és vizsgálnunk kell, hogy ez a szerv (testület) létre tude hozni egy olyan dokumentumot, amely kimeríti a jogi értelemben vett alkotmánnyal szemben támasztott követelményeket. (Arató Krisztina és Lux Ágnes Joseph Raz felosztása alapján a „thin” és a „thick” alkotmánykategóriákat alkalmazza, amelyben előbbi a tágan, míg utóbbi a szükebb (jogi) értelemben vett alkotmányt definiálja. Álláspontjuk szerint az Alkotmányszerződés - és az Alapító Szerződések is megfelelnek a „thin” kategória kritériumainak, a „thick” követelményeket azonban már nem merítik ki. ${ }^{504}$ )

Bár nem vitatom, hogy az európai alkotmányozás jogi értelemben rendkívül izgalmas és gazdag problémakört jelent ${ }^{505}$, álláspontom szerint értekezésem és az európai integráció természete szempontjából ezen a ponton az alkotmány általános értelemben vett fogalma bír nagyobb jelentőséggel. Hiszen alapvetően két kérdést kell feltennünk ahhoz, hogy európai alkotmányról beszéljünk: lehet-e Európának alkotmánya és ha igen, az milyen legyen? (Milyen formában és tartalommal létezzen?) Két lépcsőről van tehát szó, ahol az első kérdés előfeltétele a másodiknak. Ebből a szempontból egy jogi értelemben vett európai alkotmány léte technikai kérdés: hogyan épüljön fel az alkotmányozó szerv (,,alkotmányozó gyülés” - Konvent?), milyen tartalmi elemeket foglaljon magába, milyen

\footnotetext{
${ }^{503}$ Az Alkotmányszerződés elfogadásának történeti körülményeit részletesen lásd: https://www.parlament.hu/biz39/eib/link1/eualkotmany.htm ${ }^{504}$ Arató-Lux 2012, pp. 179-184.

505 Vö.: Arató-Lux 2012, pp.179-184, 192-194.
} 
legyen a szimbolikája, az értékrendje (vagy éppen az értéksemlegesség legyen az értékrendje?), stb. Bonyolult, talán lehetetlennek tünő kérdések, amelyek jelen pillanatban valószínütlennek tünő politikai konszenzusokon keresztül válaszolhatók csak meg. Illetve lennének megválaszolhatók, ha az első kérdésre, miszerint létezhet-e ilyen jogi értelemben vett alkotmány, a válasz igenlő.

Mikor felteszem a kérdést, lehet-e Európának alkotmánya, ezt arra a feltételrendszerre vonatkozóan teszem, amelyet az alkotmány fogalmánál - illetve a természetes és relatív alkotmányok korszakának elválasztásánál - már bemutattam. A kérdés akként is feltehető, hogy létezik-e Európában egy olyan egységes nép - démosz -, amely megfelelő homogenitással rendelkezik ahhoz, hogy a társadalmi együttélés rendjét egységesen szabályozott formában alakítsa ki? Képesek-e Európa népei elfogadni egy egységes társadalmi - és érték! - rendet, amely alapjául szolgálhat a jogi értelemben vett alkotmány megalkotásának? Ha az Alkotmányszerződés elfogadására tett kísérlet tapasztalataiból indulunk ki, a válasz - egyelőre - nemleges. Álláspontom szerint ezt a megközelítést támasztja alá az a tény is, hogy az Alkotmányszerződés nem az állam- és kormányfők, illetve a nemzeti parlamentek konszenzusának hiányán, vagy a „tervezőasztalon” bukott el. Az Alkotmányszerződés a közvetlen demokrácia keretén belül, népszavazáson bukott el. (Amelynek körülményeit természetesen szintén érdemes lehet vizsgálat alá vonni. ${ }^{506}$ )

Ezen a ponton szeretnék visszautalni az alkotmányos patriotizmus és az alkotmányos identitás összefüggéseinél tett megállapításomra, amely alapján az alkotmányos patriotizmus elmélete szerint az alkotmány és az azt életre hívó alkotmányos közösség viszonyában az alkotmány dominanciája érvényesül az alkotmányos közösség felett (az alkotmány formálja a közösséget, azzal hogy természetesen feltételezik egymást), míg az alkotmányos identitás elmélete fordított megközelítést alkalmaz: inkább az alkotmányos közösség formálja az alkotmányt és csak az alkotmányos közösség természetének megfelelő alkotmányt képes „befogadni”. Ha ebből a megközelítésből indulunk ki az Európai Unió viszonyában, akkor azt a következtetést vonhatjuk le, hogy az európai alkotmányos közösség még nem állt készen az önálló alkotmány létrehozására és végső soron ez eredményezte az Alkotmányszerződés bukását azáltal, hogy a közösség az annak formálására kapott felhatalmazással nem élt, pontosabban azt elutasította a nemleges

\footnotetext{
506 Vö.: Arató-Lux 2012, pp. 195-199.
} 
népszavazási döntések által. A kérdés ebben az esetben az, hogy az integrációs folyamat révén Európa népei valaha eljuthatnak-e az egység olyan fokára, ahol képesek lesznek az önálló és egységes alkotmányos rend létrehozására. Ennek a kérdésnek a megválaszolására nem vállalkozom jelen értekezés keretei között, azonban az a megállapítás álláspontom szerint megtehető, hogy a válasz alapvetően határozza meg az integráció jövőbeni fejlődésének irányát.

Ezen a ponton pedig úgy gondolom, hogy ismételten vissza kell térnünk az integráció szupranacionális jellegéhez, illetve az identitásformálás mechanizmusához, hiszen az Alapító Szerződések valamilyen szintű alkotmányos jellege mégis elvitathatatlan (vö. „thin”, illetve „thick” elválasztás) és az integráció önálló - sui generis - jogrendet alkot, amely kihatással van a társadalmi együttélés rendjére a tagállamok alkotmányos rendszerein belül.

Álláspontom szerint a szupranacionális modell egyik legvitatottabb eleme az alkotmányozó hatalom, hiszen az integráción belül a szó szoros értelmében vett alkotmányozó hatalomról sem beszélhetünk. Míg a nemzetállami és föderatív berendezkedések esetén az alkotmányozó hatalom letéteményesei általában a képviseleti demokrácia talaján álló alkotmányozó nemzetgyülések, addig az integráció viszonylatában hasonló funkciót kizárólag a tagállamok azon fóruma láthat el, amely az alapító szerződéseket létrehozza, vagyis funkcióját tekintve kvázi alkotmányozó hatalomként viselkedik. ${ }^{507}$

E ponton az alkotmányos identitás és a Jacobsohn féle alkotmányos diszharmónia elmélet az integráció szintjén értelmezve egy „új kihívással” kerül szembe. Nevezetesen, míg nemzetállami szinten az alkotmányos közösség, az alkotmányozó hatalom és az alkotmány kerül egymással konfrontációba, addig az EU szintjén e tényezők nem homogének, vagyis nem csak a három tényező között jelentkezik a konfrontatív viszony, hanem már az egyes szinteken belül is megjelenik a konfrontáció. A tagállamok amelyek az Uniót életre hívó fórumot alkotják - is folyamatos érdekellentétben állnak egymással. Következésképpen, az alkotmányos identitás létrejöttének „körforgásába” beágyazódik egy újabb szint.

${ }^{507}$ Bővebben lásd: Möllers 2011. 
Jacobsohn diszharmónia-elméletének egyik kulcsfordulata a kompromisszum az alkotmányos rendszert meghatározó „,szereplők” vagyis a közösség, az alkotmányozó és az alkotmány között. Mikor a konfrontáció nem oldható fel az egyik, vagy másik tényező dominanciájával, ez az egyetlen elképzelhető és helyes út. Gyakorlati oldalról szemlélve a jelenséget az európai integráció viszonylatában, e ponton jelentkeznek a szuverenista és integrista bélyegekkel gyakran ellátott álláspontok, eltérő politikai érdekek ütközéséből fakadóan. Hiszen e folyamat jogi, és alkotmányelméleti leképeződése pusztán keret, amelyet a tagállamokban és az integráció szintjén végbemenő politikai folyamatok és az így létrejövő kompromisszumok töltenek fel tartalommal.

Mint fentebb utaltam rá, az alapító szerződések alkotmányos jellemzői elvitathatatlanok., Ahogyan azt Möllers kifejti, az alkotmány és az alkotmányos jelző ugyan nem szükségszerüen tapad a nemzetállamokhoz, vagyis fogalmilag nem kizárt európai alkotmányról és európai alkotmányosságról beszélni, ${ }^{508}$ ebből azonban nem következik szükségszerüen, hogy az integráció viszonylatában van is értelme alkalmazni az alkotmányt, mint terminus technicust a korábban kifejtettekre és az Alkotmányszerződés ratifikálásának tapasztalataira tekintettel. ${ }^{509}$ Möllers szerint: „Nem minden alkotmányos funkciót betöltő jogi struktúra válik feltétlenül alkotmánnyá." ${ }^{10}$

Az alkotmányos identitás szempontjából, ahhoz, hogy az identitásformáló mechanizmus végbe mehessen, elégséges az alkotmányos funkciókat betöltő intézmények és dokumentumok létezésének ténye is, amelyeket az integrációban az alapító szerződések, az EU Alapjogi Kartája, és az acquis communautaire testesít meg. Következésképpen az Unió, habár nem rendelkezik kartális alkotmánnyal, ${ }^{511}$ alkotmányos jellemzőit megtestesíti több különböző dokumentum és jogelv, amelyeket maga az EUB már alkotmányos kartának minősített, és amelyeket természetesen kontinuitásban kell szemlélnünk.

\footnotetext{
${ }^{508}$ Bővebben lásd: Cananea 2010 és Möllers 2011.

${ }^{509}$ Möllers 2011, p. 11.

${ }^{510}$ Möllers 2011, p. 12.

$511 \mathrm{Az}$ EASZ hatálybalépésére nem került sor, annak egységes szerkezetbe foglalt szövegét ld. http://europa.eu/eu-law/decision

making/treaties/pdf/treaty_establishing_a_constitution_for_europe/treaty_establishing_a_constitution_for _europe_hu.pdf
} 
Megjegyzendő, hogy az alkotmányjog a jelenséghez sokban hasonlatos fogalmat már nevesít, a történeti alkotmánnyal rendelkező alkotmányos rendszerek relációjában. ${ }^{512}$ Talán túlzás volna kijelentenünk, hogy az EU történeti alkotmánnyal rendelkezik, ugyanakkor az Alapító Szerződések (különös tekintettel a LSZ-re), a Karta és az acquis az integráció alkotmányos berendezkedésére ${ }^{513}$ fundamentális meghatározó erővel, vagyis alkotmányos funkcióval bír. Amennyiben ehhez hozzávesszük a történeti alkotmány jellemzőit, miszerint: többféle (írott és íratlan) norma alkotja, e normák időben elkülönülve, egymástól részben függetlenül jönnek létre és hogy a történeti alkotmány létrejötte az ún. kompromisszumos alkotmányfejlődésre jellemző, ${ }^{514}$ akkor levonhatjuk a következtetést, hogy az integráció a történeti alkotmánnyal élő alkotmányos rendszerek jegyeit mutatja, vagyis ebbe az irányba halad. A kérdésben konkrét kijelentéseket tenni jelen pillanatban nem volna helytálló, a rendszer kiforratlanságának következtében, hiszen azt mondhatjuk, hogy az alkotmányos rendszerek több évszázados, adott esetben évezredes történelmében az EU viszonylag fiatal „alkotmányos alanynak” tekintendő. Ugyanakkor jelenti mindez azt is, hogy az EU ugyan tényleges alkotmánnyal nem rendelkezik, azonban az alkotmányosságot és alkotmányos rendszerek jegyeit, - még ha adott esetben kiforratlan formában is -, semmiképpen sem nélkülözi.

Ahhoz azonban, hogy alkotmányos identitásról beszélhessünk, mindez nem elég, hiszen amíg az alkotmányos funkciókat betöltő jogi struktúrák nem öltenek konkrétan alkotmányos jelleget, addig az integrációban európai alkotmányos identitásról aligha beszélhetünk. ${ }^{515}$ Ez úgy vélem az alkotmányos rendszerek struktúrájának természetéből fakadó törvényszerü jelenség, mivel az (alkotmányos) identitás nem egy megkonstruált, mesterséges intézmény, sokkal inkább az alkotmányos rendszer (berendezkedés) egyfajta természetes jellemzője. Ugyanakkor, ahhoz, hogy a jelenség kiteljesedhessen és az alkotmányos alany elérje azt a fejlettségi szintet, ahol identitása alkotmányos identitássá szilárdul, (vagyis a „subject” „self-fé” alakul) szükség van az entitást létrehozó szubjektumok konszenzusára abban a kérdésben is, hogy egyetlen struktúra, egyazon alkotmányos entitás égisze alatt kívánnak tovább létezni. A rövid válasz ennek hiányára a politikai konszenzus hiánya.

\footnotetext{
512 Történeti alkotmányról bővebben lásd: Zétényi 2009.

${ }^{513}$ Vö.: az integráció és a természetes alkotmányok korszakáról mondottak korábban.

${ }^{514}$ Rixer 2011

${ }^{515}$ Lásd: Az alkotmányos identitás kérdésének materiális és funkcionális megközelítését: Sulyok 2014, p. 3.; illetve vö. Tushnet 2003.
} 
Ami azonban a jelenség mögött húzódik, az a természetes alkotmányok - Deli Gergelytől korábban már hivatkozott csoportosítás alapján besorolt - korszakának jellemzőjéből, illetve az identitás formáláshoz szükséges homogenitásból fakad: alkotmányhoz és az alkotmányos identitás létrehozásához szükséges az alkotmányos közösség, amely az egyének homogén közösségét feltételezi. Kérdés, hogy Európa nemzetei a globalizáció hatására képesek-e legyőzni a taszítási feszültséget és egységes néppé alakulni, létrehozva egy európai démoszt. Ennek hiányában ugyanis a jog eszközeivel csak a fennálló struktúra hibái alakíthatók kevésbé rosszá, a feszültség azonban nem oldható fel.

Ahogyan arra Möllers és Sadurski felhívja a figyelmet, az EU-n belül a politikai akarat és az alkotmányosság kérdése különösen szoros, elemi szinten forrott össze, vagyis az alkotmányosság és a metapolitika „láncszerüen” kapcsolódik össze egymással, és formálja az integrációt. ${ }^{516}$ Amíg a fenti, társadalmi kérdésre nincs kiforrott válasz, politikai konszenzus sem képződhet és ennek hiányában az alkotmány iránti igény is hiányozni fog. Ezen a szinten az integráció nem lép túl egy szükségszerü (kényszerü?) érdekközösségen, amely szintén szükségszerüségből ölti kvázi alkotmányos jellegét. Azonban így, habár az alkotmányos identitás ugyan ott van, de még sincs ott, legfeljebb kvázi beszélhetünk európai alkotmányos identitásról.

Ahogyan arra fentebb már utaltam, az integráció alkotmányos alanyiságának vizsgálatakor két alapvető kérdés merül fel: Tekinthető-e az integráció alkotmányos alanynak és amennyiben igen, a „,subject” vagy a „,self” természetéhez áll-e közelebb? Az integrációban funkcionális szinten minden olyan „kritérium” fellelhető, amely az alkotmányos alanyt jellemzi. Hiányzik azonban a konszenzus, a képesség Európa népei között, amely igazán ,alkotmánnyá tenné az alkotmányt,” és mindez a nemzetek közötti megfelelő szintű homogenitás - pl. közös nyelv, közös értékrend, etc. - hiányára vezethető vissza. Vagyis az integráció a formálódás, az identitásformálás egy kezdeti szintjén áll, közelebb a természetes alkotmányok korszakához, mintsem a relatív korszakhoz. A rosenfeldi modell szerinti retorikában pedig közelebb áll a „subject”, mintsem a „self”, vagyis az öntudattal rendelkező ,alkotmányos alany” természetéhez. Ahogy azonban azt Sulyok az európai többszintű alkotmányossággal összefüggésben

${ }^{516}$ Vö. Sadurski 2006 és Möllers 2011 
megfogalmazza: az EU már a jogközösség és az önálló államiság között áll, és elérte „,azt a kritikus tömeget” hogy a tagállamoknak ki kell jelölniük saját szuverenitásuk határait. ${ }^{517}$

Végül megjegyzendő, hogy Rosenfeld az európai alkotmányos modellt párhuzamba állítja az identitás szempontjából az amerikai modellel, és ekként ír: „Ahogyan láthattuk, a kevés igazi amerikai létrehozott egy alkotmányt, megalapítva az államot a jövö nemzedékeinek és lefektette az alkotmányos identitás csupasz körvonalait, amely esszenciálissá vált nem csak az alkotmány jövőbeli sikereire nézve, hanem a kialakuló nemzet önnön képét tekintve is. Miért ne müködhetne egy adekvát, jövő orientált alkotmányos modell hasonló határok között Európában?"518

517 Vö.: Sulyok 2014, p. 4.

${ }^{518}$ Rosenfeld 2010, p. 173. 


\subsection{A közös metszet? Alapvető jogok és alkotmányos identitás}

Az alapvető jogok és az alkotmányos identitás fogalmai közül az alapvető jogokat már régóta evidenciaként ismerjük és alkalmazzuk, hiszen az európai alkotmányos rendszerek fundamentumát képezik, míg az alkotmányos identitást csak most kezdjük megismerni, noha utóbbi sem kevésbé képezi esszenciális lényegét az európai alkotmányos térnek, így az azt létrehozó alkotmányos berendezkedéseknek. ${ }^{519}$

Az alapvető jogok védelmének ma már kiforrott rendszere épült ki mind nemzetközi, mind európai, mind pedig az egyes tagállamok szintjén és ezek érvényesülése, érvényesítése nélkül nem is beszélhetnénk európai alkotmányos rendszerekről, de magáról az európai integrációról sem. ${ }^{520}$ Az Alapjogi Karta alapító szerződések rangjára emelésével pedig az emberi jogok tisztelete, úgy mint egykor a közös alkotmányos hagyományok, végérvényesen az integráció mozgatórugójává vált, mind alkotmányjogi, mind társadalmi-ideológiai szempontból közelítve.

Az Alapjogi Karta szerződési rangra emelése alkotmányjogi nézőpontból az integráció fejlődéseként lenne értelmezhető, amely az integráció stabilitását szilárdítaná. A gyakorlatban azonban mégsem ezt látjuk. Sőt, talán ennek ellenkezője figyelhető meg. Minél erősebb törekvések születnek az integráció elmélyítésére, stabilitásának megszilárdítására, az annál instabilabbá válik. A jelenség mögött a szupranacionális teret jellemző feszültség húzódik, amely kiegészül a szupranacionális szinten végbemenő - de csak részben beteljesíthető - identitásképzéssel. ${ }^{521}$ Ha közelebbről szemléljük az európai identitásképzés problémájának folyamatát, ${ }^{522}$ akkor szerteágazó problémarendszerrel találjuk szembe magunkat, amelynek épp úgy része az európai kulturális identitás, vagy az „európai életmód” (European Way of Life), mint a fentebb bemutatott egységes európai démosz létezésének (vagy nem létezésének) kérdése, ${ }^{523}$ de részét képezi az integrációt mozgató globalizálódó politikai-gazdasági (és pénzügyi! - vö. PSPP döntés) viszonyrendszer is.

\footnotetext{
519 Vö.: Kruzslicz 2014, pp. 7-9.

${ }^{520}$ A Kilencek 1973-ban a Koppenhágai Deklarációban az európai identitást a jogállamiság és az emberi jogok tiszteletben tartásaként fogalmazták meg. Vö: Declaration on European Identity, Copenhagen, 1973. december 14.

${ }^{521}$ Vö.: Rosenfeld 2010, p. 172.

${ }^{522}$ Vö. Martonyi 2016, p. 41.

${ }^{523}$ Vö. Paczolay 2000
} 
Ennek az identitáskeresésnek az egyik aspektusaként beszélhetünk az alkotmányos identitásról az európai integráción belül. ${ }^{524}$ Ellentétben az alapvető jogokkal, az alkotmányos identitás fogalmi rendszere csak most van születőben. A tagállami alkotmánybíróságok gyakorlatából azonban kiolvasható a tendencia, amely szerint a tagállamok számos esetben alkotmányos identitásukat az alapjogok védelme - vagy meghatározott tartalommal történő védelme - mentén kívánják meghatározni. ${ }^{525}$

Az eddig meghatározottak szerint az alkotmányos identitás a modern alkotmányos rendszerek természetének egy olyan jellemzőjeként fogható fel, amelynek két fő funkciója, egyszersmind jelentősége az önmeghatározás, illetve a megkülönböztetés az egyes alkotmányos rendszerek egyedi jellemzői által. Ebből következik, hogy az egyes alapvető jogok védelme és érvényre juttatása annyira képezheti az egyes államok alkotmányos identitásának részét, amennyire az adott alapjog meghatározza magát az alkotmányos berendezkedést és ezt a meghatározó erőt az autentikus alkotmányértelmező (általában az alkotmánybíróságok), vagy az alkotmányozó elismeri és nevesíti. (Svédország esetén ilyenként említi Smith például az információszabadságot. ${ }^{526}$ )

Meg kell jegyezni ugyanakkor, hogy az alapvető jogok érvényre juttatása és nevesítése a nemzeti alkotmányokban, révén az alkotmányosság követelményei közé sorolandók, nem elegendőek ahhoz, hogy azokra, mint alkotmányos identitásra tekinthessünk. Ehhez szükséges egy többlet elem: egyfajta megkülönböztetés az alkotmányozó, vagy a nemzeti alkotmánybíróság (felsőbb bíróság) által, amely deklarálja, hogy az adott alapvető jog az alkotmányos alkotmányos berendezkedésre olyan jelentős hatást gyakorol(t), hogy az önmeghatározásának részévé vált. Ezt a „kiemelést” hajtotta végre például a magyar alkotmányozó, amikor az emberi méltóságról szóló klauzulát - mint a közös alkotmányos hagyományok fundamentumát? - kiemelt helyen, a Nemzeti Hitvallásban (is) elhelyezte.

Az európai gyakorlatot tekintve megfigyelhető az alapvető jogok bevonása az alkotmányos identitás körébe az alkotmánybíróságok által, vagyis találhatók olyan alkotmánybírósági döntések az integráción belül, amelyek expressis verbis alkotmányos

\footnotetext{
${ }^{524}$ Rosenfeld 2010, p. 172.

${ }^{525}$ Vö.: Pérez 2013, pp.141-156, Guerra 2013, pp. 305-319.

${ }^{526}$ Ld. Smith 2016, p. 82.
} 
identitássá nyilvánítanak egyes alapjogokat. Ilyen például a német $\mathrm{AB}$ gyakorlata, amely a szavazati jogot (választójog) a német alkotmányos identitás részévé emeli. ${ }^{527}$ De példaként említhető a lett lisszabon határozat is, amelynek indítványozói többek között a közügyek vitelében történő részvételhez való jog sérelmére hivatkoztak. ${ }^{528}$

A többszintü alkotmányosság rendszerében ${ }^{529}$ az alapvető jogoknak alkotmányos identitásban történő megjelenését a korábbiak szerint vizsgálni szükséges egyrészről az egyes tagállamok tekintetében (az alkotmányos identitás belső oldala), illetve az integráció és a tagállam relációjában (az alkotmányos identitás külső oldala). Az alapvető jogok és az alkotmányos identitás kapcsolatát illetően eszerint az alábbi kérdések tehetők fel:

(i) Az egyes alapvető jogok garantálása mennyiben és hogyan formálta az adott tagállam alkotmányos identitását (és miért)?

(ii) Integrációs szinten problémaként merül fel, hogy európai perspektívából ugyanaz az alapjog hogyan és milyen formában részesül védelemben, vagyis a tagállam által egyben alkotmányos identitásként kezelt, védelemben részesített alapvető jog ugyanazzal a tartalommal kerül-e nevesítésre az integráció szintjén is? ${ }^{530}$

Martonyi az identitás-elmélet alkotmányjogi fontosságát hangsúlyozva az európai integráció koordináta-rendszerében és mintegy az identitás-fogalom központi elemeként felteszi a kérdést: Kik vagyunk mi és mit képviselünk? ${ }^{531}$ Az integráció jelenében ez azt jelenti, hogy a tagállamok, identitása hogyan határozza meg a kollektív identitáshoz füződő viszonyukat, amely - folytatja Martonyi - a politikai döntések szintjére emeli a fogalmat. ${ }^{532}$ Következésképpen a tagállamok saját alkotmányos identitásuk szemüvegén

\footnotetext{
${ }^{527}$ Sulyok 2014, p. 52.

528 Sulyok 2014, p. 58.

${ }^{529}$ Vö.: Besselink 2010, pp. 36-49.; illetve Sulyok 2015, pp. 27-39.

530 A XXVII. FIDE Kongresszuson (Budapest, 2016. május 18-21.) az Európai Unió Bíróságának hatásköreivel kapcsolatos vita során szintén kérdésként merült fel, hogy mennyire szükségszerű - illetve lehetséges-e egyáltalán - az alapvető jogok uniformizálása az integráció szintjén. Konszenzus mutatkozott a tagállamok között abban, hogy az emberi méltóság védelme megjelenhet olyan egyezö, és közös tartalommal az integráció szintjén, amely nem sérti az egyes tagállamok nemzeti alkotmányos identitását, azonban egyéb alapvető jogok esetén a tagállamok aggályokat fogalmaztak meg az uniformizáció lehetőségét és szükségszerüségét illetően.

${ }^{531}$ Martonyi in Sulyok 2016, p. 37.

532 Martonyi in Sulyok 2016, p. 37
} 
át szemlélik mind az integrációt, mind az európai alkotmányos teret. Ez később, a (ii) kérdéssel kapcsolatban részletesebben kifejtésre kerül.

Az identitás - a korábban kifejtetteknek megfelelően - nem (csak) egy adott időpontban meghatározott jellemzők összessége, sokkal inkább az alkotmányos rendszer fennállása óta, az azt lényegileg meghatározó tényezők által meghatározott egység, amelyet az adott időpontban csupán értelmezünk. Vagyis az egyes tagállamok identitásképzésének vizsgálatakor minden esetben a történelmi sajátosságokból kell kiindulni. Peter Müller például a német örökkévalósági klauzulát ${ }^{533}$ (Németország alkotmányos identitásának körében) arra a német tapasztalatra vezeti vissza, hogy a kodifikált, szabályszerü jogalkotási eljárásban megalkotott jog a „legszörnyűbb igazságtalanságokat” eredményezheti, így szükséges volt olyan biztosíték beépítése a német alkotmányos berendezkedésbe, amely még az alkotmányozót is köti. ${ }^{534} \mathrm{Az}$ alkotmánybíró ezzel kapcsolatban meg is megjegyzi, hogy mindez a német történelem specifikuma, amely nem feltétlenül érvényesül más nemzetek összefüggésében. ${ }^{535}$ Az örökkévalósági klauzula értelmében az alkotmányozó számára érinthetetlenek (többek között) a német alaptörvény emberi jogokra és az ember méltóságára vonatkozó rendelkezései. ${ }^{536}$

Hasonló logikára építhető fel a francia alkotmányos identitás, amelynek egyik legmarkánsabb eleme a laicitás ${ }^{537}$ és ezzel összefüggésben a vallásgyakorlás szabadsága. ${ }^{538}$ Történelmi gyökereit tekintve a laicitás a katolikus egyháztól való függetlenedési törekvéseket szolgálta, amely a XIX. században ellenezte a köztársasági államformát. ${ }^{539}$ A vallásszabadság gyakorlása tehát a francia alkotmányos

\footnotetext{
${ }^{533} \mathrm{Az}$ örökkévalósági klauzulát a Német Szövetségi Köztársaság Alaptörvényének 79. cikk (3) bekezdése tartalmazza, amely szerint: „A jelen alaptörvény olyan megváltoztatása, mely a Szövetség tartományokra való felosztását, a tartományok alapvető közremüködését a törvényhozásban vagy az 1 . és 20 cikkekben megállapított alapelveket érintené nem megengedett.” Az 1. cikk az emberi méltóság védelmét, míg a 20. cikk alkotmányos alapelveket és az ellenállási jogot tartalmazza. A német örökkévalósági klauzuláról részletesen lásd: Zsugyó 2019.

${ }^{534}$ Müller 2016, p. 74.

${ }^{535}$ Uo.

${ }^{536}$ Vö. Grundgesetz für die Bundesrepublik Deutschland 79. cikk (3)

537 Az Ötödik Köztársaság Alkotmánya, 2 cikk: „Franciaország oszthatatlan, laikus, demokratikus és szociális köztársaság."

${ }^{538}$ Szücs 2006, p. 97.

${ }^{539}$ Szajbély 2004
} 
berendezkedésben nem képzelhető el másként, mint a laicitás elvének érvényesítésével. ${ }^{540}$

A magyar alkotmányos identitással kapcsolatban, az Alaptörvény R) cikk (2) bekezdése, és a történeti alkotmány vívmányainak Alaptörvénybe emelése több, mint értelmezési tartomány, vagy mint értelmezési eszköz az Alkotmánybíróság számára. Olyan deklaráció, amely Magyarország történelmi sajátosságait, kialakult „identitás jegyeit” kívánja a jelenben (és a jövőben) élővé, megfoghatóvá tenni, ezzel is kinyilvánítva egyediségét, saját, mindenki mástól megkülönböztethető identitását. Az alapvető jogok és a magyar alkotmányos identitás kapcsolatában Szmodis Jenő azon álláspontja meghatározó, különösen az Alkotmánybíróság 22/2016. (XII. 5.) határozatának fényében, amely szerint a történeti alkotmány vívmányain alapvetően szabadságjogokat kell érteni, pontosabban szólva „, a szabadságok biztositásával kapcsolatos értéket, szabályokat és elveket. " ${ }^{541}$ Szmodis példaként, mint az egyik legfontosabb vívmányt, a tulajdonhoz való jogot és annak sérthetetlenségét hozza fel. ${ }^{542}$

Az alkotmányos identitás jegyei az alkotmányos rendszer önmeghatározásának elemeit jelentik, ugyanakkor manifesztációjukhoz, gyakorlati érvényesülésükhöz szükséges, hogy az Alkotmánybíróság, vagy az alkotmányozó felismerje e jelentőségüket. A történeti alkotmány vívmányai a magyar alkotmányos rendszer fejlődése során kivívott, meghatározó szegletkövek a történeti alkotmány dimenziójában, amelyeket azonosíthatunk többek között, a kivívott szabadságjogokkal.

Mikor az Alkotmánybíróság Magyarország alkotmányos identitásának meghatározásakor a történeti alkotmány vívmányaiból indult ki, élt a testület által korábban tett megállapítás által nyújtott lehetőséggel, amely szerint a történeti alkotmány vívmányai lehetőséget

\footnotetext{
${ }^{540}$ Szajbély Katalin (fent) a Stasi-bizottság jelentését idézi, mely a fogalmat a következőképpen határozza meg: „A köztársasasági paktum alapköve, amely három, elválaszthatatlanul összekapcsolódó értéken alapul: a lelkiismereti szabadság; a spirituális és vallási meggyözödések törvény elötti egyenlösége; a politikai hatalom semlegessége. A vallásszabadság minden állampolgárnak megengedi, hogy szabadon válassza meg lelki vagy vallási életét. A törvény elötti egyenlöség tilt minden diszkriminációt és kényszert, az állam egyetlen meggyözödést sem részesit elönyben. Végül a politikai hatalom tiszteletben tartja korlátait, és nem avatkozik be az állampolgárok hitéletébe. "Vö. Commission de réflexion sur l'application du principe de laicité dans la République. Bernard Stasi. 11. décembre 2003 p. 9.

${ }^{541}$ Szmodis 2013

${ }^{542}$ Szmodis 2013, p. 1.
} 
teremtenek az Alkotmánybíróság számára, hogy az egyes alapjogokat ne pusztán a jelenben vizsgálja, hanem alkotmányfejlődésünk történelmi dimenziójában. ${ }^{543}$

A tagállami alkotmányértelmező testületeknek az alkotmányos identitásról alkotott gyakorlat kialakítása során tulajdonképpen azt kell megvizsgálniuk, hogy az adott alapvető jog milyen szinten, milyen formában hatotta át a tagállam alkotmányos berendezkedésének fejlődését, illetve megjelenése, érvényesülése mennyiben formálta azt. ${ }^{544}$ Más szóhasználattal élve: az adott alapjog beépült-e alkotmányos rendszer identitásába.

További kérdésként merül fel, hogy a tagállamok alkotmányos identitásainak körében nevesített alapvető jogok ugyanazzal a tartalommal jelennek-e meg az integráció más tagállamaiban, illetve az integráció szintjén, valamint, hogy mennyiben támaszthatók integrációs követelmények az ilyen, alkotmányos identitásként nevesített alapvető jogok esetében?

A kérdés megválaszolásához Trócsányi László gondolatait hívhatjuk segítségül, mikor az európai alkotmányos örökséggel kapcsolatban a következőképpen fogalmaz: ,, A nemzeti alkotmányok szintjén nagy hangsúlyt kap az alapjogok rögzitése. Szinte ugyanazok a jogok kerülnek rögzitésre valamennyi alkotmányban: egyesülési jog, gyülekezési jog, véleménynyilvánítás joga, a magánélethez való jog, az ártatlanság vélelme, az emberi méltósághoz való jog, diszkrimináció tilalma, stb. Ezek a hasonlóságok azt bizonyítják, hogy az alapjogok terén — szemben az államszervezettel — létezik egyfajta közös nevezö, közös fejlődés. " ${ }^{45}$ Kitekintésként jegyezendő meg, ha az európai integráció esetén beszélhetnénk „európai alkotmányos identitásról,” akkor Trócsányi szavai nyomán, az alapvető jogok érvényesülése és tiszteletben tartása, a „közös alkotmányos örökség” képezhetné az integráció alkotmányos identitását, hiszen az európai identitást már ma is, mint az alapvető emberi jogok érvényesítésének és tiszteletben tartásának kultúráját aposztrofáljuk. Álláspontom szerint ez a gondolat képeződik le az EUSZ 2. cikkében, amely szerint „az Unió az emberi méltóság tiszteletben tartása, a szabadság, a

\footnotetext{
${ }^{543}$ Vö. 33/2012 (VII. 17.) ABH [75]

${ }^{544}$ Vö. Sulyok 2015, p. 37.

545 Trócsányi László: A közös európai alkotmányos örökség - Polner Ödönre emlékezve (http://www.juris.u-szeged.hu/download.php?docID=45152)
} 
demokrácia, az egyenlöség, a jogállamiság, valamint az emberi jogok - ideértve a kisebbségekhez tartozó személyek jogait - tiszteletben tartásának értékein alapul. Ezek az értékek közösek a tagállamokban, a pluralizmus, a megkülönböztetés tilalma, a tolerancia, az igazságosság, a szolidaritás, valamint a nők és a férfiak közötti egyenlöség társadalmában.” (Igaz ugyan, hogy a korábban tárgyaltak szerint nem beszélhetünk „európai alkotmányos identitásról”, azonban európai identitásról - még ha annak tartalma napjainkban konfliktusok által övezett is - mindenképpen. Az identitás-klauzulát jelen értekezésben már egy más kontextusban alkalmazom és semmiképpen sem szeretném a fogalmat túlterhelni, így jelen pontban csak egy hipotetikus kitérő erejéig vetem fel, hogy az EUSZ 2. cikkét tekinthetjük akár ez európai identitás klauzulájaként is.)

Ha elfogadjuk Trócsányi gondolatait, akkor kijelenthető, hogy a tagállamok között meghatározó a konszenzus az alapvető jogok és az EUSZ 2. cikkében rögzített értékek elismerése és garantálása iránt. Azonban Trócsányi korábban, mikor a jogállamiság egységes, az európai integráció minden tagállamára alkalmazható fogalmának hiányára hívta fel a figyelmet, rávilágított az univerzális, minden tagállamra irányadó mércék alkalmazásának nehézségeire, egyszersmind veszélyeire is. ${ }^{546} \mathrm{Az}$ univerzális értékek mindenkori elismerése egyáltalán nem előfeltételezi a feltétel nélküli unifikációt. Vagyis, a tagállamoknak, hogy az integrációban hatékonyan tudjanak részt venni, el kell fogadni annak alapvető értékeit, ugyanakkor az integráció kötelezettsége pedig az, hogy figyelembe vegye és tiszteletben tartsa a tagállamok egyediségéből származó egyes identitásjegyeit és teret hagyjon az univerzalizmus mellett a partikularizmusnak is.

Az integráció tehát megkövetelheti és az Alapjogi Karta szerződési rangra emeléséből eredően köteles is megkövetelni a nevesített alapvető jogok és európai értékek érvényesítését, azonban azok tartalmának meghatározásánál, a fentiekre tekintettel, korlátként érvényesül az egyes tagállamok alkotmányos identitásának tiszteletben tartása és a német $\mathrm{AB}$ gyakorlatában már az 1970-es években megfogalmazott nemzeti szintü védelem elve.

Mindez persze nem zárja ki annak lehetőségét, hogy az európai alkotmányos hagyományok részben - tartalmukat tekintve is - lefedjék egy adott tagállam

546 Trócsányi $2014 \mathrm{e}$ 
alkotmányos identitásának védelmét. ${ }^{547}$ Álláspontom szerint azonban, ahol kollízió keletkezik a tagállam alkotmányos identitása és az integráció között, ott az integrációnak engednie szükséges a tagállam alkotmányos identitása javára, amely ugyanakkor nem jelent parttalan engedékenységet, hiszen ahogyan Trócsányi fogalmaz: „, Természetesen a tagállam tiszteletben kell, hogy tartsa a közösség alapvetö értékeit, máskülönben aligha tudna abban hatékonyan részt venni. "548

Kérdésként merül fel azonban, hogy hol húzódik az az ésszerü határ, ameddig az integrációnak engednie szükséges? Hiszen a tagállamok alkotmányos identitásának érinthetetlennek kell lennie, azonban ezeknek az alkotmányos identitásoknak egyben a kollektív európai identitás részeként kell létezniük, vagyis szükségszerüen ki kell békíteni a kollektív identitást az azt létrehozó nemzeti identitásokkal - Anne Levade szavaival élve ,, az összeegyeztethetetlent össze kell egyeztetni. "549

Mikor az európai integrációra az alkotmányos identitás tükrén át tekintünk, szükséges észrevennünk azt, hogy minden egyes tagállam elsősorban a saját történelmi múltjának szemüvegén látja és értelmezi az európai kollektív identitást, de ennek fényében, történelmi sajátosságainak megfelelően alakítja ki önazonosságát is, ${ }^{550}$ amely egyben szükségszerüen meghatározza a többi tagállamhoz és az integrációhoz füződő magatartását. Így az „összeegyeztethetetlen összeegyeztetéséhez” a konstruktív párbeszéden kívül szükséges a szolidaritás is. ${ }^{551}$

Szolidaritás a tagállamok részéről, hogy a párbeszéd eszköze révén megismerjék és elfogadják az egyes alkotmányos identitásokból fakadó, eltérő tagállami alkotmányos hagyományokat. ${ }^{552}$ Ahogyan Trócsányi gondolataiból láthattuk, a tagállamok között vitán felül álló konszenzus uralkodik abban, hogy önmagukat az alapvető jogok biztosításának tükrében kívánják meghatározni, azonban saját történelmi, alkotmányos tradícióik fényében. A kollektív európai identitás, és az azt életre hívó tagállami

\footnotetext{
${ }^{547}$ Szakály 2015, p. 35.

548 Trócsányi $2014 \mathrm{e}$, p. 15.

${ }^{549}$ Levade 2016, p. 70.

${ }^{550}$ Ennek szemléletes példáját jelenti a Magyar Alaptörvény elfogadása, s annak európai visszhangja, melyről bővebben ld: Trócsányi 2014a.

551 Vö. Schuman-nyilatkozat (http://europa.eu/about-eu/basic-information/symbols/europe-day/schumandeclaration/index_hu.htm)

552 Vö.: Müller 2016, p. 78.
} 
alkotmányos identitások között fennálló feszültséget, noha enyhíteni lehet - és a jövőben talán kibékíteni is - a párbeszéd és a szolidaritás értékeivel, teljesen feloldani nem lehetséges, mivel a tagállamok és az integráció közötti ellentét komplexebb, árnyaltabb problémakör, amely a korábban ismertetettek szerint államelméleti, államszervezeti kérdések megválaszolását - és döntések meghozatalát - teszi szükségessé. ${ }^{553}$

${ }^{553}$ Vö. Sulyok 2014, 46-50. 


\section{Alkotmányos identitás Magyarországon}

A tagállami alkotmánybíróságok a közös hatáskörgyakorlásról, a hatáskör- és szuverenitástranszferről, illetve a közösségi és nemzeti jog összhangjáról először az ún. Lisszabon-döntésekben foglaltak állást, ${ }^{554}$ majd ezeket további, már speciálisabb területekre fokuszáló határozatok követték, mint pl. a német PSPP döntés. Sulyok a tagállami Lisszabon-döntéseket aszerint kategorizálja, hogy az alkotmányértelmező testületek elemzik, illetve alkalmazzák-e az EUSZ 4. cikkből fakadóan az alkotmányos identitás fogalmát. ${ }^{555}$ Eszerint többek között Franciaország, Németország, és Lengyelország esetében alkalmazásra kerül az alkotmányos identitás doktrínája, míg - az akkori példák alapján - Dánia, Lettország, és Csehország esetében az abból fakadó következtetéseket találhatunk. ${ }^{556}$ Ezzel szemben 2016. decemberéig Magyarország az integráció azon tagállamainak sorába tartozott, amelyekben az alkotmányértelmező testületek nem éltek az alkotmányos identitás alkalmazásának, egyszersmind az EUSZ 4. cikk (2) értelmezésének lehetőségével. A magyar Lisszabon-határozat, ${ }^{557}$ amely a Lisszaboni Szerződést kihirdető 2007. évi CLXVIII. törvény alkotmányosságát vizsgálta, megszületését követően több kritikát kapott, miszerint a határozat kevés újat hozott, az Alkotmánybíróság lényegében deklarálta korábbi gyakorlatát, azonban a közösségi jog és a nemzeti jog összeütközésének dogmatikai problémáival csak érintőlegesen foglalkozott, ${ }^{558}$ illetve a testület adós maradt egy szuverenitásvédelmi teszt kialakításával is. ${ }^{559}$ Az Alkotmánybíróság tehát 2010-ben lényegében nem jelölte ki a követkendő irányvonalat az európai integráció és Magyarország alkotmányos viszonyát tekintve. A 143/2010 (VII.14.) AB határozatban az alkotmányos identitás fogalmára csak Trócsányi László - korábban már hivatkozott - párhuzamos indokolásában találunk utalást.

Az európai menekültválság és az ezzel egyidőben felerősödő európai identitásválság hatására 2016-ban az Alkotmánybíróság a 22/2016. (XII. 5.) AB határozattal elérkezettnek látta az időt, hogy az EUSZ 4. cikk (2) bekezdését újabb megfontolás tárgyává tegye és az EUSZ hivatkozott rendelkezésének az Alaptörvénnyel történő

\footnotetext{
${ }^{554}$ Szakály 2015, pp. 24-38.

555 Sulyok 2014, p. 51.

${ }^{556}$ Az egyes tagállamok Lisszabon döntéseinek részletes ismertetését bővebben lásd: Sulyok 2014, pp. 51 60., illetve Drinóczi 2016b, pp. 7-14.

557 143/2010. (VII. 14.) AB határozat

558 Vincze-Chronowski 2018, pp. 277-280.

559 Blutman 2010, p. 99.
} 
összevetésével, illetve értelmezésével betöltse az ürt, amely a(z) (első) Lisszabonhatározat óta nyitott kérdésként kezelte az EUSZ 4. cikk (2)-ből eredő alkotmányos következményeket a magyar vonatkozásban. ${ }^{560}$

Az alkotmányos identitás magyarországi gyakorlatának második meghatározó eleme az Alaptörvény hetedik módosítása volt, amelyet 2018. június 20-án fogadott el az Országgyülés és amely a Nemzeti Hitvallásban, illetve a R) cikkben rögzíti megközelítőleg az Alkotmánybíróság 22/2016. (XII. 5.) AB határozatának megfelelően - az alkotmányos identitás védelmét. Ezzel hazánk az európai integráció tagállamai közül elsőként rögzítette alkotmányi szinten - jelen sorok szerzője szerint vitatható helytállósággal - az alkotmányos identitás védelmét. ${ }^{561}$

${ }^{560}$ Az Alkotmánybíróság egyúttal kialakította a korábban számára felrótt szuverenitásvédelmi tesztet, amelyet azonban ezt követően szintén számos kritika ért. Vö.: Drinóczi 2017b, pp. 8-13, ChronowskiVincze 2017, pp.104-119.

${ }^{561}$ Bővebben lásd az Alaptörvény hetedik módosításáról szóló részt. 


\subsection{A 22/2016. (XII. 5.) AB határozat}

Az Alkotmánybíróság 22/2016. (XII. 5.) AB határozatában (a továbbiakban: identitáshatározat) lefektette, hogy az alkotmányos identitás fogalma alatt Magyarország alkotmányos önazonosságát érti és annak tartalmát az Alaptörvény egészére, különösen az R) cikk (3) bekezdésére tekintettel esetröl-esetre bonja ki, fokozatosan újra és újra megfontolás tárgyává téve a Lisszaboni Szerződés és az Alaptörvény egymásra vonatkoztatott értelmezéséből hazánk szempontjából következő identitás-határokat. ${ }^{562}$ Egyúttal az Alkotmánybíróság az alkotmányos identitásra, mint a tagállamok és az európai integráció közötti hídra tekint, mikor leszögezi, hogy annak védelmét az egyenjogúság és kollegialitás alapelvein alapulóan, egymás kölcsönös tisztelete mellett folytatott együttmüködés (ti. tehát alkotmányos párbeszéd) keretében indokolt meghatározni az Európai Unió Bíróságával. ${ }^{563}$

Az alapvető jogok biztosa az Alaptörvény XIV. cikk, illetve az E) cikk (2) bekezdés vonatkozásában, az érintett cikkek értelmezésével kapcsolatban fordult az Alkotmánybírósághoz. A XIV. cikkel összefüggésben a Biztos a csoportos kiutasítás tilalmára tekintettel kérte az Alaptörvény értelmezését, míg az E) cikk (2) bekezdését érintően annak értelmezését kérte, hogy

(i) Magyarország köteles-e olyan intézkedések végrehajtására, amelyek az Alaptörvénybe ütköznek,

(ii) egy uniós jogi aktus sértheti-e az alapjogokat (alapjogi fenntartás), illetve

(iii) az ombudsman további „útmutatást” kért a testülettől az ultra vires közösségi aktusokat illetően.

Az Alkotmánybíróság az indítványban szereplő kérdéseket végzéssel elkülönítette és a XIV. cikk értelmezését külön eljárásban látta célszerűnek lefolytatni, ${ }^{564}$ míg az E) cikkre vonatkozó kérdéseket a fenti pontok szerint tárgyalta. $\mathrm{Az}$ identitás-határozat meghozatalát követően a jogtudomány képviselői számos kritikát fogalmaztak meg, ${ }^{565}$ azonban az e kritikák kereszttüzében formálódó viták az alkotmányos identitás

562 22/2016. (XII. 5.) AB határozat [64]

563 22/2016. (XII. 5.) AB határozat [63]

564 22/2016. (XII. 5.) AB határozat [29]

565 Vö.: Drinóczi 2017b, Chronowski-Vincze 2017 
koncepciójának soha nem látott jogtudományi feldolgozottságát indukálták. Értekezésemben célom az identitás-határozat jelentőségének bemutatása azon tárgykörökben, amelyek a testület korábbi Lisszabon-döntésében nem kerültek lefektetésre, így különös tekintettel az EUSZ 4. cikk (2) bekezdésére és az alkotmányos identitás jegyeinek meghatározására magyar viszonylatban. Ezért a határozat vizsgálatát és bemutatását a továbbiakban ennek tükrében végzem el.

Az Alkotmánybíróság az indítvány ismertetését és saját hatáskörének megállapítását követően a felmerült kérdésekkel kapcsolatban az indokolásban széleskörü komparatív vizsgálatot folytat a tagállamok alkotmánybírósági, illetve alkotmánybírósági feladatokat ellátó legfelsőbb bírósági gyakorlatát illetően. ${ }^{566}$ E komparatív vizsgálat ${ }^{567}$ fényében helyezkedik a testület arra az álláspontra, hogy kivételes esetben és ultima ratio jelleggel vizsgálhatja, hogy a hatáskörtranszfer révén az unióra ruházott hatáskörgyakorlás folytán sérül-e alapvető jog lényeges tartalma, Magyarország szuverenitása, vagy alkotmányos önazonossága. ${ }^{568}$

Az Alaptörvény E) cikk (2) bekezdés folytán megvalósuló közös hatáskörgyakorlás alapjogsérelmet eredményező voltával kapcsolatban az Alkotmánybíróság az alapjogi fenntartást hívja fel és megállapítja, hogy Magyarország tekintetében a közhatalom gyakorlása alapjogilag kötött, és az alapjogok e primátusa alól a tagállamokkal közösen megvalósuló hatáskörgyakorlás sem jelent kivételt. ${ }^{569}$ A német Solange döntésekre ${ }^{570}$ hivatkozással a testület deklarálja, hogy az Alkotmánybíróságnak az európai jog lehetőség szerinti érvényesülését szem előtt tartva kell eljárnia az alapjogok védelmére irányuló és a közös hatáskörgyakorlás következtében az Alkotmánybíróság részére fenntartott felülvizsgálat során. A testület azonban elvi éllel jegyzi meg, hogy - ultima ratio jelleggel - biztosítania kell, hogy még „az E) cikk (2) bekezdése alapján megvalósuló közös hatáskörgyakorlás sem járhat az emberi méltóság vagy más alapvetö jogok lényeges tartalmának sérelmével." 571

\footnotetext{
566 22/2016. (XII. 5.) AB határozat [33] - [45]

567 A komparatív vizsgálat dominanciája, olykor kizárólagossága kritikaként fogalmazódik meg a testület döntését illetően. Lásd bővebben: Drinóczi 2017b, p. 6.

568 22/2016. (XII. 5.) AB határozat [46]

569 22/2016. (XII. 5.) AB határozat [47] - [49]

${ }^{570}$ A Német Alkotmánybíróság Solange I. és II. döntéséről bővebben lásd: Marinkás 2013, p. 100.

571 22/2016. (XII. 5.) AB határozat [49]
} 
Az ultra vires aktusokkal kapcsolatban ${ }^{572}$ az Alkotmánybíróság az Alaptörvény E) cikkére tekintettel rávilágít, hogy az Alaptörvényben megjelenő „Európa-klauzula” egyszerre teszi lehetővé az uniós jogrend Magyarországon történő érvényesítését, egyszersmind az ennek révén megvalósuló közös hatáskörgyakorlás korlátját is jelenti. ${ }^{573}$ Minderre tekintettel az Alkotmánybíróság az Alaptörvény E) cikk (2) bekezdésére, illetve az EUSZ 4. cikk (2) bekezdésére alapozva az európai integráción belüli közös hatáskörgyakorlás korlátjaként létrehozza a szuverenitáskontrollt, illetve Magyarország alkotmányos önazonossága védelmében az identitáskontrollt. ${ }^{574}$ Ezzel összefüggésben az Alkotmánybíróság lényegében a jogtudományban az alkotmányos identitásról kialakult konszenzust ${ }^{575}$ deklarálja és erősíti meg, mikor kimondja, ${ }^{576}$ hogy az alkotmányos identitás védelmének legfőbb letéteményese az Alkotmánybíróság. Az Alkotmánybíróság tehát az ultra vires aktusok megítélését illetően passzív álláspontot fogalmazott meg és a hangsúlyt az alkotmányos identitás irányába próbálta terelni. A korábbiak szerint a német alkotmánybíróság ennek éppen az ellenkezőjét tartotta követendő irányvonalnak. Értekezésemben csak utalok arra, hogy a magyar Alkotmánybíróság egy későbbi döntése - a 2/2019. (III. 5.) AB határozat - az uniós és a hazai jogrend kapcsolatával ${ }^{577}$ részleteiben is foglalkozik. A testület ezen határozatának nincs fókuszában az alkotmányos identitás, azonban az egy évvel későbbi német PSPP döntéssel lényegében megegyező következtetéseket fogalmaz meg az uniós jog korlátait illetően.

Identitás-határozatában a fenti, elméleti jellegű deklarációt követően az $\mathrm{AB}$ megjegyzi: „a szuverenitás-, illetve az identitáskontroll tárgya nem közvetlenül az uniós jogi aktus, illetve annak értelmezése, igy annak érvényességéröl vagy érvénytelenségéröl, illetve alkalmazásbeli elsőbbségéről sem nyilatkozik.” Az Alkotmánybíróság megállapításának első két fordulata helytálló, hiszen az uniós jogi aktus értelmezésére, illetve érvényességének / érvénytelenségének megállapítására csak az EUB jogosult, azonban kérdéses, hogy a szuverenitás- és/vagy identitáskontroll alá vont uniós jogi aktus alkalmazhatósági kérdéseiről sem nyilatkozhat-e a nemzeti alkotmánybíróság, hiszen

\footnotetext{
572 Vö.: Fazekas 2009, pp.81-86.

573 22/2016. (XII. 5.) AB határozat [53]

574 22/2016. (XII. 5.) AB határozat [54]

575 Sulyok 2014, p. 51., illetve vö.: Szakály 2015, p. 35. és Drinóczi 2016b, p. 2.

576 22/2016. (XII. 5.) AB határozat [55]

577 Az uniós és a hazai jogrend kapcsolatára vonatkozó alkotmánybírósági gyakorlat elemzését bővebben lásd: Sulyok-Kiss 2019, pp. 397-402, illetve Hamul'ák - Sulyok -Kiss 2019.
} 
pontosan ezt tette az ultra vires aktusokra hivatkozással a német alkotmánybíróság az identitás-határozatot négy évvel követő PSPP döntésben.

Az Alkotmánybíróság a szuverenitáskontrollt az Alaptörvény B) cikkére alapozva a népszuverenitásból vezeti le. Eszerint, a parlamet által gyakorolható államhatalom nem korlátlan - annak korlátait az Alaptörvény deklarálja - , az Alaptörvényben a hatalom végső forrásaként pedig a nép jelenik meg. A testület megfogalmazása szerint „,mindaddig, amíg az Alaptörvény B) cikke a független, szuverén államiság elvét tartalmazza és a közhatalom forrásaként a népet jelöli meg, ezeket a rendelkezéseket az E) cikk szerinti uniós klauzula nem üresitheti ki." ${ }^{578}$ Arra, hogy mit ért a testület az Alaptörvény fenti rendelkezéseinek - ti. a szuverenitás - kiüresítése alatt, a határozat további indokolásából következtethetünk. Az Alkotmánybíróság rögzíti, hogy a szuverenitás, mint „a hatáskörök végső forrása,” és nem mint hatáskör kerül megjelenítésre az Alaptörvényben, és ezért a tagállamok által közösen gyakorolt hatáskörök folytán a nép nem veszítheti el végső ellenörzési lehetőségéta közhatalom gyakorlása felett. ${ }^{579}$

Több nemzeti alkotmánybíróság határozatában (pl. Lengyel Alkotmánybíróság K 32/09, 24.11.2010. döntése) ${ }^{580}$ jelenik meg, hogy amennyiben az adott tagállam szuverenitását sértő közösségi aktussal kerül szembe, úgy a tagállam előtt milyen lehetőségek állnak, amennyiben az összeütközés feloldása nem lehetséges. Így pl. az alkotmány módosítása, kilépés az EU-ból, stb. Vagyis, miután az EUSZ 50. cikke lehetőséget biztosít a tagállamoknak az integráció elhagyására, melyről a nemzeti parlamentek, azonban ahogy a közelmúlt példáján is láttuk, sokkal inkább közvetlen demokrácia gyakorlása útján népszavazással az adott tagállam alkotmányos közössége, a nép határozhat, igen nehezen képzelhető el olyan tényleges körülmény, mikor a nép valamely közösségi aktus, közös hatásgyakorlás révén elveszíti a „,végső ellenőrzési lehetőségét a közhatalom gyakorlása felett."

Az identitáskonrollal kapcsolatos álláspontjának kifejtését az Alkotmánybíróság az arra jogi alapot szolgáltató EUSZ 4. cikk (2) bekezdésének felhívását követően egy

578 22/2016. (XII. 5.) AB határozat [59]

579 22/2016. (XII. 5.) AB határozat [60]

${ }^{580}$ Vö.: Drinóczi 2016b, pp. 10-16. 
deklarációval kezdi, amelyben lefekteti, hogy az alkotmányos identitás védelmét a tagállami alkotmánybíróságoknak az EUB-vel folytatott együttmüködés keretében, az egyenjogúság és kollegialitás alapelveinek figyelembevételével indokolt biztosítania. ${ }^{581}$

Ahogyan arra korábban utaltam, az európai integráción belül az egyes tagállamok alkotmányos identitásának meghatározását illetően törekvés mutatkozik a tagállamok részéről a tekintetben, hogy az egyes tagállami identitás meghatározására a tagállamok legfőbb alkotmányértelmező testületei jogosultak. ${ }^{582}$ Kérdésként merül fel azonban, hogy egy-egy tagállami alkotmánybíróság által nevesített identitásra hogyan regál az uniós jog autentikus értelmezőjeként az Európai Unió Bírósága? Vajon sikkerrel hivatkozhat-e egy tagállam az EUB előtt egy közösségi aktussal szemben a tagállami alkotmánybíróság által az alkotmányos identitás körébe vont és ez által az EUSZ 4. cikk (2) bekezdés általi védelemben részesülő önazonosságára? ${ }^{583}$

Hiszen míg az alkotmányos önazonosság meghatározására a tagállam jogosult, egy esetleges jogvita esetén a jogvitát lezáró „,végső szó” az Európai Unió Bíróságát mint az uniós jog autentikus értelmezőjét illeti. ${ }^{584}$

Igaz ugyan, hogy az „európai alkotmányos párbeszéd” és az „egyenjogúság és kollegialitás alapelvein nyugvó kölcsönös együttmüködés” a tagállami alkotmánybíróságok és az Európai Unió Bírósága között nem az alapító szerződésekből fakadó „kikényszeríthető” kötelezettség, ugyanakkor a szupranacionális környezet sajátosságaira és kielégítő elsődleges jogbéli szabályozás hiányára tekintettel egy fontos eszköz az alkotmányértelmezők kezében. Olyan eszköz, amely enyhítheti, vagy akár el is mélyítheti az integráción belüli feszültségeket, ezért annak felelős és érdemi gyakorlása kötelezettség mind a tagállami alkotmányértelmező testületek, mind az EUB számára, 585 és amely a PSPP döntést követően vélhetően kérdéses utat fog bejárni a jövőben.

581 22/2016. (XII. 5.) AB határozat [63]

582 Vö.: Besselink 2010, p. 42. és Sulyok 2014, p. 51.

${ }^{583}$ AZ EUB eddigi joggyakorlatának ismertetését bővebben lásd például: Drinóczi 2016b, pp. 3-6.

584 Vö: EUMSz 344. cikk és ABH [76], Dienes-Oehm Egon alkotmánybíró párhuzamos indokolása, valamint Szakály 2015, p. 35.

${ }^{585}$ Holisztikus szempontból akár azt is mondhatjuk, hogy e testületek, mint az alkotmányosság európai őrei az „európai alkotmányos párbeszéd” és az ,egyenjogúság és kollegialitás alapelvein nyugvó kölcsönös együttmüködés” által válhatnak önazonossá alkotmányértelmezö, s az alkotmányosság védelmét betöltő végső lényegükkel. Ezen a ponton szükséges ismét utalni a C-357/19 sz. ügyre, amelyben az EUB gyakorlatilag az itt felmerülő kérdésekröl fog véleményt formálni. 
A fenti deklarációt követően az Alkotmánybíróság elvi éllel mondja ki, hogy ,az alkotmányos identitás fogalma alatt Magyarország alkotmányos önazonosságát érti, és tartalmát az Alaptörvény egésze, illetve egyes rendelkezései alapján, az R) cikk (3) bekezdése szerint azok céljával, a Nemzeti Hitvallással és a történeti alkotmányunk vívmányaival összhangban, esetről-esetre bontja ki. "586 Megjegyzendő, hogy a határozat azon fordulata, amelyben az alkotmánybíróság kifejti, hogy ,az alkotmányos identitás fogalma alatt Magyarország alkotmányos önazonosságát érti” funkcióját tekintve nyelvi, fogalmi pontosításnak tünik. Talán integrációszerte jelentett volna a határozat mérföldkövet, egyúttal jelentette volna egy régóta húzódó értelmezési vita végét, ha az Alkotmánybíróság az EUSZ 4. cikkére reflektálva azt deklarálja, hogy a nemzeti identitás fogalma alatt Magyarország alkotmányos önazonosságát érti.

Az alkotmányos identitás jogtudományi meghatározásával összhangban ${ }^{587}$ az Alkotmánybíróság lefekteti, hogy az alkotmányos önazonosság nem statikus és zárt értékek jegyzéke, ${ }^{588}$ majd példálódzó jellegü felsorolást ad, amelyben Magyarország alkotmányos önazonosságának körébe vonja: „, a szabadságjogok, a hatalommegosztás, a köztársasági államforma, a közjogi autonómiák tiszteletetét, a vállásszabadságot, a törvényes hatalomgyakorlást, a parlamentarizmust, a jogegyenlöséget, a birói hatalom elismerését, valamint a velünk élö nemzetiségek védelmét." 589 Noha a felsorolás példálódzó jellegü, a példálódzó jelleg inkább az alkotmányos önazonosság dinamikus, „,időkön átívelö” jellegére ${ }^{590}$ vonatkozik, sem mint a felhívható értékek pontos meghatározhatatlanságára.

Annál is inkább, mivel az Alkotmánybíróság tesz további két olyan megállapítást, amely a felsoroltakat központi megvilágításba helyezi: e szerint az Alkotmánybíróság a felhívott identitásjegyeket alkotmányos értékekként azonosítja, valamint kijelenti, hogy „ezek történeti alkotmányunk olyan vívmányai, amelyeken az Alaptörvény és általa a magyar jogrendszer nyugszik. " ${ }^{591}$ A testület további olyan esetköröket is felvet, amelyek esetében

586 22/2016. (XII. 5.) AB határozat [64].

${ }^{587}$ Vö.: Jacobsohn 2010, pp. 1-35, Jacobsohn 2013, p. 1. és Rosenfeld 2010, pp. 37-65.

588 22/2016. (XII. 5.) AB határozat [65]

589 22/2016. (XII. 5.) AB határozat [65]

${ }^{590}$ Vö.: Rosenfeld 1995, p. 1049.

591 22/2016. (XII. 5.) AB határozat [65] 
- feltételes jelleggel - felmerülhet az alkotmányos önazonosság védelme, mint pl. a magánszféra védelme, vagy Magyarország nyelvi, történelmi, kulturális identitása. ${ }^{592}$

Megjegyzést érdemel azonban, hogy az Alkotmánybíróság által az alkotmányos identitás körébe vont alapvető jogok, illetve alkotmányos értékek köre olyan tág kategóriát hozott létre, amely a jövőben feltehetően szúkítést, illetve pontosítást igényel. Az Alkotmánybíróságot feltehetően aktivista szemlélet vezette a koncepcióban rejlő lehetőségek megragadása érdekében, amely azonban így álláspontom szerint túl széles határokat szabott az identitáselemek meghatározásához. Egyúttal azonban az így kialakult helyzet kiválóan rávilágít az alkotmányos identitás dinamikus jellegére és arra az értekezésben korábban - Jacobsohn nyomán - tett kijelentésemre, hogy ez a dinamikus jelleg nem jelenthet korlátlan változékonyságot. Az identitás-határozat kijelölt egy pályát az alkotmányos identitás hazai tartalmának, az azonban, hogy ez a pálya milyen íven halad majd, a jövő kérdése. Az Alkotmánybíróságnak kell az identitás-határozat fényében pontosítania az identitáselemek tartalmát, amelyet azonban nem önkényes mérlegelés eredményeként tehet majd meg: tekintettel kell lennie a társadalmi és alkotmányos környezetre. Fel kell ismernie, hogy az a környezet, amely 2016-ban a fenti katalógus meghatározását tette szükségessé, hogyan változik, hová fejlődik és ennek fényében kell a szükséges korrekciókat, szükítéseket elvégeznie. A német példa pedig továbbra is irányadó jelleggel szolgálhat: a Szövetségi Alkotmánybíróság korábbi gyakorlatában az alapvető jogok védelme hangsúlyosabb szerepet játszott az alkotmányos identitás tartalmát illetően, azonban a pénzügyi önrendelkezés identitás-elemkénti rögzítése - igaz kisebb hangsúllyal -, de végig jelen volt a testület gyakorlatában. ${ }^{593}$ A PSPP program és az azzal összefüggő gazdasági következmények olyan környezetet hoztak létre, amely az utóbbi dominánsabbá válását eredményezte.

Megjegyzést érdemel továbbá - figyelemmel a korlátlan változékonyság veszélyére -, hogy tekintettel arra, hogy az Alkotmánybíróság az alkotmányos identitás forrásául Magyarország történeti alkotmányát jelölte meg, problémásan indokolható a köztársasági államformának az alkotmányos identitás körében történő deklarálása (hiszen az nem a történeti alkotmányból fakad), amely így vélhetően a jövőben szintén pontosításra szorul majd a testület részéröl.

592 22/2016. (XII. 5.) AB határozat [66]

${ }^{593}$ Vö.: Az ún. OMT határozat - 2 BvR 2728/13 [77], [94] 
Az Alkotmánybíróság a határozat indokolásának alkotmányos identitásról szóló szakaszát azzal a megállapítással zárja, miszerint az alkotmányos önazonosság olyan alapvető érték, amelyet nem az Alaptörvény hoz létre, az alkotmányos önazonosságot az Alaptörvény pusztán elismeri, illetve egy adott alkotmányos rendszert - az $\mathrm{ABH}$ konkretizáltan Magyarországot illetően tesz megállapításokat, azonban e megállapítások általánosságban is alkalmazhatóak az alkotmányos identitás vizsgálata során - csak akkor lehet megfosztani alkotmányos önazonosságától, ha annak önálló államisága véglegesen megszünik. ${ }^{594} \mathrm{Az}$ Alkotmánybíróság végül megjegyzi, hogy „a szuverenitás és az alkotmányos önazonosság számos ponton érintkezik, így a rájuk vonatkozó két kontrollt egyes esetekben egymásra tekintettel kell elvégezni. "595

Az Alkotmánybíróság indokolásában lefektetett tételt, miszerint az alkotmányos identitás az alkotmányos rendszerhez (berendezkedéshez) tartozó érték és azt az alkotmány pusztán elismeri, már az indokoláshoz csatolt különvélemények között is egyet nem értés övezte. ${ }^{596}$ Azonban a korábban kifejtettek szerint az Alkotmánybíróság álláspontja illeszkedik a jelenleg az alkotmányos identitásról alkotott egyetlen olyan dogmatikai rendszerbe, amely jogelméleti, jogfilozófiai alapokon nyugszik, ${ }^{597}$ és amelynek megalkotói Michel Rosenfeld és Gary J. Jacobsohn. ${ }^{598}$ E szerint az alkotmányos identitás hordozója szükségszerüen egy olyan entitás, amelyet az adott identitás „,egyediesít,” tesz önmagával azonossá. ${ }^{599}$ Az alkotmányos rendszernek ugyan meghatározó alkotóeleme maga az alkotmány, ${ }^{600}$ azonban az alkotmány identitása és az alkotmányos identitás elhatárolásánál tett megállapítások alapján nem tehető egyenlőségjel az alkotmányos rendszer és magának az alkotmánynak az identitása közé.

Az alkotmányos identitás fogalomkörét érő egyik kritika, hogy jelenleg nem pontosan körülhatárolt és az egyes önazonosságra vonatkozó tételek ezért több kérdést vetnek fel, mint amelyet megválaszolnak. ${ }^{601}$ Az Alkotmánybíróság által lefektett tétel álláspontom

\footnotetext{
594 22/2016. (XII. 5.) AB határozat [67]

595 22/2016. (XII. 5.) AB határozat [67]

${ }^{596}$ Vö.: Stumpf István alkotmánybíró párhuzamos indokolása, ABH [109], valamint Drinóczi: 2017b, p. 10.

${ }^{597}$ Lásd az alkotmányos identitás jogelméleti alapjainál mondottakat és vö.: Rosenfeld 2010, pp. 37-38.

${ }^{598}$ Kettejük elméletei nem alkotnak ugyan egymásra tekintettel kialakított egységes rendszert, az elméletek azonban összhangban állnak, egymást kiegészítik.

${ }^{599}$ Az identitás fogalmának pszichológiai meghatározásából kiindulva. Vö.: Bodó 2004, p. 40.

${ }^{600}$ Vö: Jürgen Habermas Alkotmányos patriotizmus (Verfassungspatriotismus) elmélete: Müller 2008.

${ }^{601}$ Drinóczi 2016b, p. 41.
} 
szerint éppen ezen bizonytalanságokat igyekszik eloszlatni, mikor a fenti deklarációra épít. A határozat kritikájaként fogalmazható meg, hogy az Alkotmánybíróság ugyan megállapítja e tételt, de nem fejti azt ki. ${ }^{602}$ Ugyan a magyar alkotmánybírósági gyakorlatban nem megszokott a jogtudományos álláspontokra történő hivatkozás, ezen a ponton talán indokolt lett volna az idézett jogelméleti rendszer felhívása a határozat indokolásában.

Az identitás-határozat további jelentős megállapítása a történeti alkotmány vívmányai ${ }^{603}$ és az alkotmányos önazonosság meghatározó összetevői közötti párhuzam deklarálása. A két fogalom közötti összefüggés átfogó elemzését a magyar jogirodalomban először Szakály Zsuzsa végezte el. ${ }^{604}$ Szakály 2015-ben a két fogalom közötti kapcsolódási pontokat tekintve azt a kérdést tette fel, hogy egyes alkotmányos alapelvek, értékek, vagy alapvető jogok történeti alkotmány vívmányaként történő deklarálása értelmezhetö-e identitásformáló kérdésként? ${ }^{605}$ Szakály szerint - ha a válasz igen - a két fogalmi kör egyes elemeinek közös halmaza ezáltal kettős védelem alá kerülne és azon vívmányok, amelyek egyben az alkotmányos identitás részei, nevesíthetőek lennének „kvázi örökkévalósági klauzulákként” is. ${ }^{606}$ (Szakály tehát, bár nem nevesítette, már 2015-ben utalt az alkotmányos identitás külső és belső oldalának megnyilvánulására, illetve az alkotmányos identitás és az örökkévalósági klauzulák összefüggéseire az alkotmányos stabilitás eszközrendszerének vizsgálatában. ${ }^{607}$ )

Mind a történeti alkotmány vívmányainak, mind az alkotmányos identitás egyes jegyeinek meghatározása az Alkotmánybíróság feladata ${ }^{608}$ és mint ilyen, a testület az identitás-határozatban deklarálta, hogy a két fogalom egyes elemei közös halmazt alkothatnak. $^{609}$ Ezáltal beigazolódott Szakály felvetése az alkotmányos identitás és a történeti alkotmány vívmányainak közös metszetéröl. Nevezetesen, hogy a történeti alkotmány egyes vívmányai értelmezhetőek identitásformáló tényezőkként. ${ }^{610} \mathrm{Nem}$

\footnotetext{
${ }^{602}$ Vö.: Varga Zs. András alkotmánybíró párhuzamos indokolása, ABH [111]

${ }^{603}$ Alaptörvény R) cikk (3) bek., vö.: 33/2012 (VII. 17.) ABH

604 Szakály 2015

${ }^{605}$ Szakály 2015, p. 25.

606 Uo.

${ }^{607}$ Lásd Szakály 2015, illetve Szakály 2018, pp. 144-153,

608 22/2016. (XII. 5.) AB határozat [64] és 33/2012 (VII. 17.) AB határozat [74] - [75]

609 Érdekes vizsgálódási szempontot képezhet a jövőben az alkotmányos önazonosság és a történeti alkotmány vívmányainak összehasonlítása, illetve elkülönítése.

${ }^{610}$ Szakály felveti, hogy az alkotmányos identitás és a történeti alkotmány vívmányainak közös metszetére „kvázi örökkévalósági klauzulaként” is tekinthetünk. Magyarországon természetesen annak alkotmányi
} 
kevésbé hangsúlyos megállapítása az Alkotmánybíróságnak a jövőre nézve az a tétel, mikor a fogalom dinamikus, „időkön átívelő” jellegére tekintettel, példálódzó jelleggel és a korábban már jelzett módon, jelen értekezés szerzője szerint túlságosan tág körben Magyarország alkotmányos önazonosságának meghatározó összetevőjeként nevesíti „, $a$ szabadságjogok, a hatalommegosztás, a köztársasági államforma, a közjogi autonómiák tiszteletetét, a vállásszabadságot, a törvényes hatalomgyakorlást, a parlamentarizmust, a jogegyenlöséget, a bírói hatalom elismerését, valamint a velünk élö nemzetiségek védelmét," majd ezeket egyben történeti alkotmányunk vívmányaiként határozza meg. Azáltal, hogy az Alkotmánybíróság a történeti alkotmány vívmányaiként nevesítette a felsorolt értékeket, azokat az Alaptörvény R) cikk (3) bekezdésére tekintettel egyúttal az Alaptörvény értelmezési tartományának szintjére is emelte. ${ }^{611}$

A többszintü alkotmányosság rendszerében olyan felelösség hárul a tagállami alkotmányértelmező testületekre, amely a szupranacionális jogrendszer kialakulását megelőzően nem létezett. Nevezetesen nem pusztán a nemzeti alkotmányok védelmezőjeként és értelmezőjeként szükséges e testületek fellépése, de mivel a tagállami és az integrációs jog viszonya az Alapító Szerződések rendelkezéseiből közvetlenül és egyértelműen nem levezethető, ezért a tagállami alkotmányos sajátosságok, az alkotmányos identitás és a közösségi jog együttélésének mostoha gyermekeként úgy tünik az Alkotmánybíróságokra hárul az a feladat, hogy meghúzzák a határvonalat a tagállami alkotmányos rendszerek és a közösségi jog között. E feladat azonban végső soron nem telepíthető az alkotmányértelmezö testületekhez.

Mi sem példázza ezt jobban, hogy bár egyre kiterjedtebb az alkotmányos identitásról és a közös hatáskörgyakorlásról született alkotmánybírósági gyakorlat az integrációban, a német PSPP döntésig mind a nemzeti alkotmánybíróságok, mind pedig az Európai Unió Bírósága igyekezett elkerülni a „nyílt kenyértörés” pillanatát a testületek között. Az továbbra is várat magára, hogy az EUSZ 4. cikkére tekintettel akár a tagállamok alkotmánybróságai, akár az integrációs közösségi jog értelmezőjeként az EUB kimondja elsőbbségét a közösségi jog és a tagállami alkotmányos identitás összeütközése esetén,

szintü rögzítése nélkül ezt a fogalmat nem alkalmazhatjuk, funkcióját tekintve azonban valóban hasonlóság mutatkozik. Érdemes azonban megjegyezni, hogy a német Alaptörvény (Grundgesetz) örökkévalósági klauzulája a német alkotmányos önazonosság központi, meghatározó elemét képezi. Vö.: Müller 2016, pp. 73-78.

${ }^{611}$ Vö.: Az Alaptörvény többrétegüsége: Szmodis 2013,pp. 156-158. 
és feltehetően a jövőben a fókusz nem is az alkotmányos identitásra, sokkal inkább az ultra vires aktusokra helyeződik majd - ahogy ezt a fentiekben már kifejtettem.

Az Alkotmánybíróság 22/2016. (XII. 5.) AB határozatát illetően, a határozatot ért kritikák ellenére ${ }^{612}$ álláspontom szerint 2016-ban egy meghatározó jelentőségű határozat született, amely - bár indokolásában talán kiegészítésre és további magyarázatra szorult volna, ${ }^{613}$ hiánypótló jellegével alkalmas arra, hogy betöltse azt az ürt, amelyet a magyar Lisszabondöntés hagyott maga után 2010-ben.

${ }^{612}$ Vö.: Drinóczi 2017b, pp. 10-14.

${ }^{613}$ Vö.: A határozathoz füzött párhuzamos indokolások. 


\subsection{Az Alaptörvény hetedik módosítása}

Az alkotmányos identitás gyakorlatának második állomásaként a 2018. június 20-án elfogadott hetedik Alaptörvény-módosítás tekinthetö ${ }^{614}$, amely két ízben rögzíti alaptörvényi szinten az alkotmányos identitás védelmét az alábbiak szerint:

- Nemzeti Hitvallás: „Valljuk, hogy a történeti alkotmányunkban gyökerező önazonosságunk védelmezése az állam alapvetö kötelessége."

- R) cikk (4) bekezdés: „Magyarország alkotmányos önazonosságának és keresztény kultúrájának védelme az állam minden szervének kötelessége."

A hetedik módosítás gyakorlatilag az Alkotmánybíróság identitás-határozatában foglaltak alaptörvényi szintü rögzítését jelenti, amely azonban - Drinóczi szavaival élve - talán több problémát vet fel, mint amennyit megválaszol. ${ }^{615} \mathrm{Az}$ alkotmányos identitás koncepciója eltérően értelmezett fogalom, amelyet a jogtudomány és a jogalkalmazók is eltérően határoznak meg, nem csak tagállamok között, de tagállamokon belül is. Ezen kívül olyan fogalomról van szó, amelyet nem csak tagállamok egy elszeparált csoportja kíván meghatározni. Az alkotmányos identitás koncepciója az integráció egyre több tagállamában nyer egyre nagyobb jelentőséget. Igaz ugyan, hogy a magyar Alaptörvény vonatkozásában, mint erga omnes alkotmányértelmező, kizárólag az Alkotmánybíróság által kialakított gyakorlat lehet meghatározó, ugyanakkor az instabilitás, illetve az inkonzisztencia veszélyét hordozza egy olyan fogalom rögzítése, amelynek a tartalma egyelőre évről évre változik (fejlődik).

Egyúttal további kérdéseket is felvet a hetedik módosítás által alkalmazott megszövegezés, mivel nem egyértelmü, hogy a történeti alkotmányban gyökerező önazonosság, illetve az alkotmányos önazonosság alaptörvényi fogalma ugyanarra a tartalomra vonatkozik-e. A kérdés eldöntése természetesen ezúttal is az Alkotmánybíróság kompetenciája, azonban a testület identitás-határozatát az Alaptörvény hetedik módosításának fényében értelmezve, a határozatban foglaltak problematikus kötelezettséget rónak az ,állam minden szervére”, hiszen az Alkotmánybíróság Magyarország alkotmányos identitását „,nem statikus és zárt értékek

614 Vö: Orbán 2020, pp. 87-88.

615 Vö.: Drinóczi 2016b, p. 30. 
jegyzéke"-ként határozta meg. Következésképpen az identitás-határozat és az R) cikk (4) bekezdés együttes értelmezése olyan kötelezettséget keletkeztet valamennyi állami szerv számára, amely a „nem statikus és zárt értékek jegyzékének” védelmére irányul. 


\section{VI. Összefoglalás}

Értekezésemben az alkotmányos identitás európai koncepciójának elméleti kérdéseire fektettem a hangsúlyt, ezért a tagállami alkotmánybíróságok ${ }^{616}$, illetve az EUB ${ }^{617}$ gyakorlatának részletes ismertetését mellőztem, azonban törekedtem megjeleníteni valamennyi olyan, átfogónak tekinthető jogtudományi vizsgálatot, amely ezen folyamatosan bővülő - joggyakorlat feltérképezését tüzte ki célul. Kutatásom során, betöltött jelentőségére tekintettel, kivételt képez ez alól a Német Szövetségi Alkotmánybíróság 2020. május 5-én született PSPP döntése és a Magyar Alkotmánybíróság 22/2016. (XII. 5.) AB határozata, amelyek elemzését magam is részletesen elvégeztem. Összességében értekezésem fókuszában egy olyan elméleti fogalomrendszer kidolgozása állt, amely bár nem kizárólagos, alkalmas lehet hozzájárulni az alkotmányos identitás koncepciójának érthetőbbé, letisztultabbá, egyszersmind alkalmazhatóvá válásához.

$\mathrm{Az}$ identitásképzés modelljénél és az alkotmányos identitás elméleti fogalomrendszerének kialakításánál kutatási előfeltevésem szerint az alkotmányos identitás természete a két fogalmi komponens, majd azok kapcsolatának elemzésével határozható meg. Ezért az identitás fogalmának vizsgálata során annak szociálpszichológiai törvényszerüségeiből indultam ki Bodó Barna és Erik H. Erikson tételei alapján. A vizsgálat során abból az előfeltevésből indultam ki, hogy a természetes személyek identitásképzésének folyamata során megvalósuló mechanizmusok alkalmazhatóak az államok, alkotmányos rendszerek identitásképzésének folyamata során is, tekintettel arra, hogy az alkotmányos identitás kialakításakor az identitást hordozó szubjektumok az államok és így a természetes személyekhez hasonló konfrontatív viszony alakulhat ki közöttük, illetve a kollektív identitásképzés törvényszerüségei is megegyezhetnek a természetes személyeknél tapasztaltakkal.

Az alkotmány fogalmának meghatározásakor Deli Gergely munkássága alapján a természetes és relatív alkotmányok korszakát vizsgáltam az identitásképzés

${ }^{616}$ Ezek hazai szakirodalmi feldolgozását lásd: Sulyok 2014, Drinóczi 2016b, Drinóczi 2016c, Somssich 2018, stb.

${ }^{617}$ Annak részletes, a hazai szakirodalomban egyedülálló feldolgozását lásd: Orbán 2020 korábban hivatkozott fejezetei. 
szempontjából, amely vizsgálat során megállapítottam, hogy az európai integráció a természetes alkotmányok korszakának megfelelő tulajdonságokat hordoz. Az alkotmányfogalom elemzésével az alkotmány funkcióinak katalógusát kiegészítettem az európai jogrend és a tagállami alkotmányos berendezkedések közötti kapcsolat megteremtésével, illetve az alkotmányos identitás védelmével.

Az alkotmányos identitás elméleti alapjait Michel Rosenfeld és Gary J. Jacobsohn elméleteinek eredői mentén alkottam meg, amely alapján az alábbi megállapításokat tettem:

(i) Az alkotmányos identitás az alkotmányos rendszer organikus fejlődésének folyamatát írja le, amelynek egyes meghatározó elemei az alkotmányos közösség, az alkotmányozó hatalom és az alkotmány, amely három tényező kölcsönhatásaként jön létre maga az alkotmányos (rendszer) berendezkedés.

(ii) A létrejövő alkotmányos berendezkedés identitása e három tényező konfrontatív viszonyban ölt testet az egyensúly biztosításával: a három faktor egymás által meghatározott, így azok változása is csak összhangban képzelhető el.

(iii) Az alkotmányos identitás egyik meghatározó tulajdonsága ezért a kontinuitás, vagyis az alkotmányos rendszer identitását egyetlen időpillanatban, zárt értékek katalógusával nem lehetséges kielégítően meghatározni. Az alkotmányos berendezkedés statikus jelenségként értelmezhető, az annak kialakítására képes - organikusan fejlődő - entitás az alkotmányos alany.

(iv) Amennyiben egy adott időpillanatban nevesíteni kívánjuk egy alkotmányos rendszer identitásának elemeit, azok az alkotmányos rendszert alkotó tényezők (alkotmányos közösség, alkotmányozó hatalom, alkotmány) konfrontatív viszonyának eredményeként az alkotmány rendelkezései között, mint alkotmányos értékek és intézmények, alkotmányos alapelvek öltenek testet, amelyek megjelenhetnek az alkotmánybírósági / felsőbb bírósági esetjogban, mint identitáselemek. 
Az alkotmányos identitást az európai szupranacionális térben

(i) mint a tagállami alkotmányos rendszerek önmeghatározását, az alkotmányos berendezkedéseket meghatározó olyan történelmi eredettel rendelkező alapvető alkotmányos értékek, elvek és intézmények rendszereként határoztam meg, amelynek tiszteletben tartása az EUSZ alapján az Unió kötelezettsége, és

(ii) amely az alkotmányos rendszerrel (berendezkedéssel) együtt járó, annak egyediségét megtestesítő olyan minőség, amely az alkotmányos közösség, az alkotmányozó hatalom és az alkotmány konfrontatív viszonyának eredményeként a nemzeti alkotmányokban, alkotmány erejü törvényekben manifesztálódik.

Az értekezésben tett megállapításokra tekintettel javaslatot fogalmazok meg a nemzeti alkotmányos identitás, illetve a tagállami identitás fogalmának mellözésére az alkotmányos identitás fogalomrendszerében, illetve elhatárolom egymástól a nemzeti identitást, mint az alkotmányos közösség, és az alkotmányos identitást, mint az alkotmányos rendszer identitását. Teszem mindezt azzal a megállapítással, hogy az EUSZ 4. cikk (2) bekezdésében található nemzeti identitás fogalom integrációs értelmezésben az alkotmányos identitás fogalmával azonosítható.

Értekezésemben az integráció szupranacionális jellegére tekintettel elhatárolom egymástól az alkotmányos identitás külső és belsö oldalát, hasonlóan a szuverenitás külső és belső oldalához. Álláspontom szerint az alkotmányos identitás belső oldala védelmének egyik megnyilvánulási formája az örökkévalósági klauzulák alkalmazása, amelyekkel az alkotmányaikban örökkévalósági klauzulát alkalmazó tagállamok alkotmányos berendezkedésük inherens, belső magját kívánják védelemben részesíteni. Az alkotmányos identitás külső oldala a tagállamok és az integráció konfrontatív viszonyában ölt testet, amely az Alapító Szerződések és így az uniós jog szintjén az EUSZ 4. cikk (2) bekezdésében manifesztálódik. Az alkotmányos identitás és az örökkévalósági klauzulák közötti kapcsolat vizsgálata érdekében 2018-ban társkutató közremüködésével kérdőívet készítettünk, amelyet az Alkotmánybíróság útján juttattunk el a tagállami alkotmányértelmező testületeknek. A tagállami alkotmánybíróságok gyakorlatának feltérképezésére irányuló kérdőívet hazánk és további nyolc tagállam (Ausztria, 
Csehország, Horvátország, Lettország, Málta, Németország, Szlovákia, Szlovénia) töltötte ki és küldte vissza.

Értekezésemben elkülönítetten kezelem az EUSZ 4. cikk (2) bekezdésének első és második fordulatát, amelyeket álláspontom szerint egymásra tekintettel, de elkülönülten kell értelmezni. Az első fordulat tartalmazza a szoros értelemben vett identitás-klauzulát, amely a tagállamok alkotmányos berendezkedésének egyedi elemeit hivatott védelemben részesíteni: a tagállami alkotmányos berendezkedések azon intézményeit, alkotmányban rögzített értékeit, amelyek kizárólag az adott alkotmányos berendezkedés - történelmi fejlődés eredményeként létrejövő - egyedi jellemzőiként tekintendők (Pl. laicitás Franciaország, történeti alkotmány vívmányai - Magyarország, köztársasági államforma és emberi méltóság - Németország, stb.).

Az EUSZ 4. cikk (2) bekezdésének második fordulata szerint az Unió tiszteletben tartja a tagállamok alapvető állami funkcióit, amely rendelkezés értelmezhető kvázi a szuverenitás klauzulájaként is. Az alapvető állami funkciók meghatározása olyan generális kérdés, amely valamennyi tagállamra általánosan vonatkozik. A tagállamok alkotmányának és az uniós jogrend összeütközésének kérdése olyan fundamentális viszonyrendszert feltételez, amely valamennyi tagállam esetén azonos tartalommal kell, hogy bírjon. A tagállami alkotmányok és az uniós jogrend összeütközésének ,általános”, szuverenitási kérdésekre visszavezethető esetei - amelyek a hatáskörátruházásra vezethetők vissza - az EUSZ 4. cikk (2) bekezdés második fordulata alapján oldhatók fel.

Megállapítottam, hogy az EUSZ 4. cikk (2) bekezdése a tagállami integritás védelmének három dimenzióját határozza meg:

(i) egyrészről az unió tiszteletben kell, hogy tartsa a tagállamok szerződések előtti egyenlőségét,

(ii) nemzeti identitását és

(iii) alapvető állami funkcióit.

E hármas védelem hivatott garantálni, hogy az európai integráció többszintü alkotmányos, szupranacionális rendszerében az unió tagállamainak alapvető alkotmányos berendezkedése, állami integritása a tagállammá válást követően is biztosított legyen. Az EUSZ 4. cikk (2) bekezdésének két fordulata közül tehát az első egyedileg, esetről esetre 
vonatkozik a tagállamokra és minden esetben egyedi mérlegelés tárgya (nemzeti identitás), míg a második fordulat a szuverenitás európai integrációban történő érvényesülésének uniós jogi klauzulája, amely valamennyi tagállam esetében azonos tartalommal bír.

A vizsgált fordulatok elválasztása és egymástól elkülönülten történő értelmezése alapján az a következtetés vonható le, hogy a Lisszaboni Szerződés e rendelkezése a nemzeti, vagy alkotmányos identitás fogalmának szükítő értelmezését jelenti: európai értelmezésben a tagállamok és az integráció viszonyából fakadó szuverenitási kérdések nem tartoznak a nemzeti / alkotmányos identitás fogalmi köréhez, azok tudományos szempontból államelméleti, míg döntéshozatali szempontból politikai kérdésekként értelmezhetők.

Végül az európai integrációt egyrészről a szupranacionalitás oldaláról, másrészről az identitásképzés mechanizmusának oldaláról közelítem meg, felvázolva az értekezésben kifejtettek alapján kirajzolódó lehetséges fejlődési irányokat.

Értekezésem során végig törekedtem azon meglátásom bemutatására, amely szerint az alkotmányos identitás nem egy mesterséges intézmény, amely korlátlanul átformálható. Az alkotmányos identitás számos vélekedéssel ellentétben nem eszköze politikai törekvéseknek. Formálódását nem lehet „kikényszeríteni” és így az alkotmányos identitást nem lehet „megalkotni”. Ahogy Jacobsohn írja: Változhat, de ellenálló, elpusztíthatatlan - és eltérő helyzetekben különbözőképpen jelenhet meg. ${ }^{618}$

Az alkotmányos identitás sokkal inkább - a szuverenitáshoz hasonlóan - egy tulajdonság, ismérv. Jogrendszereink természetének jellemzője és így sokkal inkább születik, mint sem megalkotják. Az alkotmányos identitás folyamat. Folyamat, amely formál és összeköt társadalmat, alkotmányozót és alkotmányt. Egy olyan kivetülés, amely egyesíti az alkotmányos rendszer múltját és jelenét, így határozva meg annak jövőjét, vagyis Rosenfeld szavait idézve: „időkön átívelö.”619

618 Jacobsohn 2013, p. 5.

${ }^{619}$ Rosenfeld 2010, p. 41. 
Az alkotmányos identitás tehát nem kizárólag az alkotmánybíróságok, autentikus alkotmányértelmező fórumok joggyakorlatában jön létre. Ott pusztán a legmarkánsabb módon leképeződik. Az alkotmányos identitás együtt él és változik a szubjektummal, amelyhez kötődik. Egy tükör, amely egy adott pillanatba süríti össze az alkotmányos rendszer múltját, jelenét és jövőjét. ${ }^{620}$

Értekezésemben többször használtam a „pajzs” és a „híd” metaforákat, amelyekkel az alkotmányos identitás európai integrációs folyamatban betöltött szerepét - pontosabban e szerep egyes aspektusait - szerettem volna érzékeltetni. Megközelítéstől függően ismeretes azonban a „pajzs” és a „kard” dichotómia ${ }^{621}$ is hasonló célzattal. ${ }^{622}$ Kutatásom $^{2}$ során az előbbi kettőt éreztem helyénvalónak, hiszen az integráción belül minden különbözőség és esetleges eltérő értékrend ellenére az európai nemzetek egy irányba tartanak, egy irányba kell, hogy tartsanak. Nincs tehát szükségünk kardra, hidakat pedig építeni és nem felégetni kell.

Mikor az integrációs folyamatot fékezni kell, mert a tagállamok „,kevesebbé” válnának általa (feloldódnának az integrációs folyamatban), az identitás pajzsként müködik, amely védi a tagállamok önazonosságát: a tagállami alkotmányos berendezkedéseket védi attól, hogy ahogyan Jacobsohn már idézett mondata hangzik, valami egészen mássá alakuljanak át. ${ }^{623}$ Az alkotmányos identitás azonban egy híd is a kollektív identitásképzés folyamatában: egy híd, amely áthidalhatja a formálódó európai identitás és az azt létrehozó európai nemzetek közötti szakadékot és segít védeni a tagállamok egyedi történelméből fakadó értékrendjét és önazonosságát, biztosítandó ezáltal magát az integrációs együttmüködést az egyensúly fenntartása által.

Ahhoz azonban, hogy mind a tagállamok, mind az integráció az alkotmányos identitásra, mint az integrációt meghatározó és végső soron az egység stabilitását fenntartó mechanizmusra tekinthessenek, előfeltétele, hogy az alkotmányos identitás elméleti

\footnotetext{
${ }^{620}$ Vö. az Alaptörvény Nemzeti Hitvallását az alábbiak szerint: ,Vállaljuk, hogy örökségünket, egyedülálló nyelvünket, a magyar kultúrát, a magyarországi nemzetiségek nyelvét és kultúráját, a Kárpát-medence természet adta és ember alkotta értékeit ápoljuk és megóvjuk. Felelösséget viselünk utódainkért, ezért anyagi, szellemi és természeti eröforrásaink gondos használatával védelmezzük az utánunk jövö nemzedékek életfeltételeit."

${ }^{621}$ Vö.: Faraguna 2017, p. 1627.

${ }^{622}$ Faraguna az EUSZ identitás-klauzulájára a bírói hatalom „tömegpusztító fegyvere” (judicial “nuclear weapon”) hasonlatot alkalmazza. Vö.: Faraguna 2016, p. 521.

${ }^{623}$ Jacobsohn 2013
} 
alapjai kiforrottá váljanak és azonos tartalommal épüljenek be a joggyakorlatba, mind a tagállamok, mind az integráció szintjén.

Végezetül Csink Lóránt, az alkotmányos identitás fogalmának meghatározásakor elhangzott szavait szeretném idézni, amely szerint „,identitás nélkül nem vagyunk azok, amik vagyunk. Ez az identitás tesz minket azzá, amik vagyunk."624 Amikor pedig a kollektív európai és az egyes nemzeti identitásokra tekintünk, azt az Európai Unió Alapjogi Kartájának preambulumában lefektetett deklaráció fényében kell tennünk, amely szerint „Európa népei, az egymás közötti egyre szorosabb egység létrehozása során úgy döntöttek, hogy osztoznak a közös értékeken alapuló békés jövőben."

${ }^{624}$ Csink 2016, p. 145. 


\section{Forrásjegyzék}

\subsection{Felhasznált irodalom}

Ádám 2010: Ádám Antal: Az alkotmányi értékek értelmezéséről. In JURA, 2010/2. szám, 115-127.

Ádány 2016: Ádány Tamás Vince: Nemzetközi jogi szempontok a migrációs válság értelmezéséhez. In Iustum Aequum Salutare, 2016/2. szám, pp. 237-249.

Anderson 2006: Benedict Anderson: Elképzelt közösségek. L’Harmattan Kiadó, Budapest, 2006

Angyal 2007: Angyal Zoltán: Az Európai Alkotmányszerződés ratifikációs válsága, avagy a közvetlen demokrácia és az integráció kollíziója. In Sectio Juridica et Politica, Miskolc, Tomus XXV/1 (2007), 175-190.

Antal 2017: Antal Attila: Létezhet-e transznacionális alkotmányos identitás transznacionális politikai szubjektum nélkül? In Fundamentum, 2017/1-2. szám, pp. 3336.

Arató-Lux 2012: Arató Krisztina - Lux Ágnes: Az Európai Unió alkotmányozási kísérlete. In Jakab András - Körösényi András (szerk.): Alkotmányozás Magyarországon és máshol: politikatudományi és alkotmányjogi megközelítések, Új Mandátum Kiadó, MTA Társadalomtudományi Kutatóközpont Politikatudományi Intézet, Budapest, 2012, pp. 177-199.

Arnaiz-Llivina 2013: Alejandro Saiz Arnaiz -, Carina Alcoberro Llivina: Why Constitutional Identity Suddenly Matters: A Tale of Brave States, a Mighty Union and the Decline of Sovereignty. In Alejandro Saiz Arnaiz -, Carina Alcoberro Llivina (eds.): National constitutional identity and european integration. Intersentia, Cambridge Antwerp - Portland, 2013, pp. 1-16. 
Balázs 2015: Balázs Zoltán: Az Alaptörvény, a politikai funkció és az R cikkely. In Fundamentum, 2015/2-3. szám

Balogh-Békési 2008: Balogh-Békési Nóra: „Közös európai alkotmányjog” vagy szuverenitás-transzfer esetről esetre. In Jogtudományi Közlöny, 2008/6. szám, pp. 310315.

Balogh-Békési 2014: Balogh-Békési Nóra: Szuverenitásféltés és alkotmány. In MTA Law Working Papers, 2014/57.

Belov 2017: Martin Belov: The Functions of Constitutional Identity Performed in the Context of Constitutionalization of the EU Order and Europeanization of the Legal Orders of EU Member States. In Perspectives on Federalism, 2017/2. szám, pp. 72-97.

Besselink 2007: Leonard F.M. Besselink: Composite European Constitution, Paperback. Europa Law Publishing, 2007

Besselink 2007: Leonard F.M. Besselink: Composite European Constitution, Paperback, Europa Law Publishing, 2007

Besselink 2010: Leonard F.M. Besselink: Constitutional Identity Before and After Lisbon. In Utrecht Law Review, 2010/3. szám, pp. 36-49.

Bihari 2014: Bihari Mihály: A modern szuverenitás elméleti alapjai - Kísérlet egy funkcionalista rendszerszemléletű szuverenitáselmélet alapjainak kidolgozására. In MTA Law Working Papers, 2014/51. szám

Bihari-Pokol 2013: Bihari Mihály, Pokol Béla: Politológia - A politika és a modern állam. Pártok és ideológiák, Nemzeti Tankönyvkiadó, 2013

Blanke - Mangiameli 2013: Hermann-Josef Blanke - Stelio Mangiameli (eds.): The Treaty on European Union (TEU) A Commentary, Springer, Heidelberg - New York Dordrecht - London, 2013 
Blutman 2010: Blutman László: A magyar Lisszabon-határozat: befejezetlen szimfónia luxemburgi hangnemben, Alkotmánybírósági szemle, 2010/2. szám

Blutman 2013: Blutman László: Az Európai Unió joga a gyakorlatban (Második, átdolgozott kiadás), HVG Orac, Budapest, 2013

Blutman 2017: Blutman László: Szürkületi zóna: Az Alaptörvény és az uniós jog viszonya. In Közjogi Szemle, 2017/1. szám, 1-14.

Blutman 2019: Blutman László: Szuverenitás, szupranacionalitás, szubszidiaritás. In Fejes Zsuzsa - Szalai Anikó (szerk.): Államközi kapcsolatok. Iurisperitus Kiadó, Szeged, 2019

Blutman-Chronowski 2007: Blutman László - Chronowski Nóra: Az alkotmánybíróság és a közösségi jog: alkotmányjogi paradoxon csapdájában. In Európai Jog 2007/2. szám, 3-16.

Bodó 2004: Bodó Barna: Az identitás egyetemessége. Polis könyvkiadó, Kolozsvár, 2004.

Bodó-Toró 2011: Bodó Barna - Toró Tibor: Kisebbségpolitika és az Európai Unió Egyetemi jegyet, Sapientia - Erdélyi magyar Tudományegyetem, Természettudományi és Mủvészeti Kar, Nemzetközi kapcsolatok és európai tanulmányok szak, Kolozsvár, 2011 - http://et.sapientia.ro/admin/data/file/20141216/kisebbsagpolitika-jegyzet.pdf

Bogdandy-Schill 2011: Armin Von Bogdandy - Stephan Schill: Overcoming Absolute Primacy: Respect for National Identity under the Lisbon Treaty. In Common Market Law Review 2011/48. szám, 1417-1454.

Bogdandy 2005: Armin Von Bogdandy: The European constitution and European identity: Text and subtext of the Treaty establishing a Constitution for Europe. In I·CON, Volume 3, No. 2 \& 3: Special Issue May, 2005, pp. 295-315. 
Bulmer 2014: Elliot Bulmer: What is a Constitution? Principles and concepts. In International IDEA Constitution-Building Primer 1, 2014

Chronowski 2005: Chronowski Nóra: Integrálódó alkotmányjog. Dialóg Campus Kiadó, Budapest-Pécs, 2005

Chronowski 2015: Chronowski Nóra: Globális vagy lokális alkotmányosság? In Jogelméleti szemle, 2015/4. szám, 19-31.

Chronowski 2020: Chronowski Nóra: Fordulópont az európai bírói párbeszédebn: a német Szövetségi Alkotmányíróság PSPP döntése. In Közjogi Szemle, 2020/2. szám, pp. 74-80.

Chronowski-Vincze 2017: Chronowski Nóra - Vincze Attila: Alapjogvédelem, szuverenitás, alkotmányos önazonosság: az uniós jog érvényesülésének új határai. In Chronowski Nóra (szerk.): Szuverenitás és államiság az Európai Unióban. ELTE Eötvös Kiadó, Budapest, 2017

Csink - Fröhlich 2012: Csink Lóránt - Fröhlich Johanna: Egy alkotmány margójára. Alkotmányelméleti és értlemezési kérdések az Alaptörvényről, Gondolat Kiadó, Budapest, 2012

Csink 2015: Csink Lóránt: Az Alaptörvény identitása - honnan hová? In Tóth Judit (szerk.): Ünnepi kötet Dr. Tóth Károly címzetes egyetemi tanár 70. születésnapjára, Acta Universitatis Szegediensis, Acta Juridia Et Politica, Szeged, 2015

Csink 2016: Csink Lóránt összefoglaló előadása. In Sulyok Márton (szerk.): Párbeszéd és Identitás - Az alkotmányos identitás alapkérdései. Magyar Közlöny Lap- és Könyvkiadó Kft., Budapest, 2016, pp. 145-150.

Degenhart 2019: Christoph Degenhart: Staatsrecht I., C.F. Müller GmbH, Heidelberg, 2019 
Degré 1980: Degré Alajos: Az ellenállási jog története Magyarországon. In Jogtudományi Közlöny, 1980/6. szám, pp. 366-371.

Deli 2018: Deli Gergely: Az eleven jog fájáról: elmélet és történet a természetjog védelmében, Médium, Budapest, 2018

Deuter-Bradbery-Turnbull 2015: Margaret Deuter - Jennifer Bradbery - Joanna Turnbull: Oxford Advanced Learner's Dictionary of Current English (Kilencedik átdolgozott kiadás). OXFORD University Press, UK, 2015

Dorsen-Rosenfeld-Sajó-Baer 2003: Norman Dorsen - Michel Rosenfeld - András Sajó - Susanne Baer: Comparative constitutionalism, West Group, USA, 2003

Drinóczi 2016a: Drinóczi Tímea: Jogrendszerek versenye és alkotmányos párbeszéd. In Iustum Aequum Salutare, 2016/2. szám, pp. 213-233.

Drinóczi 2016b: Drinóczi Tímea: Az alkotmányos identitásról. Mi lehet az értelme az alkotmányos identitás alkotmányjogi fogalmának? In MTA Law Working Papers, 2016/15. szám

Drinóczi 2016c: Drinóczi Tímea: Nemzeti és alkotmányos identitás az EU-ban és tagállamaiban. In Tilk Péter: Az uniós jog és a magyar jogrendszer viszonya, Pécsi Tudományegyetem Állam- és Jogtudományi Kar, Pécs, 2016

Drinóczi 2017a: Drinóczi Tímea: Az alkotmányos párbeszéd. A többszintü alkotmányosság alkotmánytana és gyakorlata a 21. században, Jogtudományi Alapkutatások 1., az MTA TK JTI elektronikus monográfiasorozata, Budapest, 2017

Drinóczi 2017b: Drinóczi Tímea: A 22/2016 (XII. 5.) AB határozat: mit (nem) tartalmaz, és mi következik belőle? Az identitásvizsgálat és az ultra vires közös hatáskörgyakorlás összehasonlító elemzésben, MTA Law Working Papers, 2017/1.

Drinóczi 2018a: Drinóczi Tímea: A tagállami identitás. In MTA Law Working Papers, $2018 / 8$ 
Drinóczi 2018b: Drinóczi Tímea: The identity of the constitution and constitutuonal identity: Opening up a discourse between the Global South and Global North. In Iuris Dictio 2018/21. szám, 63-80.

Faraguna 2016: Pietro Faraguna: Taking Constitutional Identities Away from the Courts. In Brooklyn Journal of International Law, Volume 41, Issue 2, pp. 492-525.

Faraguna 2017: Pietro Faraguna: Constitutional Identity in the EU-A Shield or a Sword? In German Law Journal, Volume 18, No. 07, pp. 1618 - 1640.

Fassbender 2018: Bardo Fassbender: The state's unabandoned claim to be the center of the legal universe. In ICON - International Journal of Constitutional Law, Vol. 16 No. 4 October 2018, pp. 1207-12014.

Fazekas 2009: Fazekas Flóra: A Magyar Alkotmánybíróság viszonya a közösségi jog elsőbbségéhez egyes tagállami alkotmánybírósági felfogások tükrében, Doktori $(\mathrm{PhD})$ értekezés, Debrecen, 2009

Fazekas 2015: Fazekas Flóra: Az uniós tagság alkotmányos alapjai az Alaptörvény elött és után, Pro Futuro 2015/1.

Fejes 2014a: Fejes Zsuzsanna: Globalizáció - demokrácia - integráció: az Európai Unió állam- és politikaelméleti kihívásai a 21. században. In Blutman László - Homoki-nagy Mária (szerk.): Ünnepi kötet Dr. Bodnár László egyetemi tanár 70. születésnapjára, Szegedi Tudományegyetem Állam- és Jogtudományi Kar, Szeged, 2014, pp. 111-121.

Fejes 2014b: Fejes Zsuzsanna: Az Európai Unió államtani jellege. In Forum: Acta Juridica et Politica 4, 2014, pp. 55-67.

Fejes 2015: Zsuzsanna Fejes: Constitutional Identity and Historical Constitution Clause in the Hungarian Fundamental Laww and its Effect on Constitutional Interpretation. In Zoltán Szente - Fanni Mandák - Zsuzsanna Fejes (eds.): Challenges and Pitfalls in the 
Recent Hungarian Constitutional Development. Discussing the New Fundamental Law of Hungary, L'Harmattan, Paris, 2015, pp. 25-44.

Fekete 2017: Fekete Balázs: Szuverenitás-egyesítés az Európai Unió alkotmányjogában. In Chronowski Nóra (szerk.): Szuverenitás és államiság az Európai Unióban. ELTE Eötvös Kiadó, Budapest, 2017, pp. 9-26.

Forgó 2009: Forgó Ferenc: Mivel foglalkozik a játékelmélet? In Magyar Tudomány, 2009/5. szám

Fossum 2017: Jon Erik Fossum: Identity-politics in the European Union. In ARENA Eorking Papers, 2017/1. szám

Gárdos-Orosz 2019: Gárdos-Orosz Fruzsina: Többszintü alkotmányosság. In GárdosOrosz Fruzsina - Halázs Iván (szerk.): Bevezetés az alkotmányjogba: alapfogalmak, Dialóg Campus Kiadó - Nordex Kft., Budapest, 2019, pp. 373-380.

Gisbert 2013: Rafael Bustos Gisbert: National Constitutional Identity in European Constitutionalism: Revisiting the Tale of the Emperor's New Clothes in Spain? In In Alejandro Saiz Arnaiz -, Carina Alcoberro Llivina (eds.): National constitutional identity and european integration. Intersentia, Cambridge - Antwerp - Portland, 2013, pp. 75-92.

Goldmann 2020: Matthias Goldmann: As Darkness Deepens: The Right to be Forgotten in the Context of Authoritarian Constitutionalism. In German Law Journal, Vol. 21. Issue 1, pp. $45-54$.

Grimm 2012: Dieter Grimm: Types of Constitutions. In Michel Rosenfeld - András Sajó: The Oxford Handbook of Comparative Constitutional Law, Oxford University Press, New York, 2012, 98-133.

Grósz 2019: Grósz Laura: Jogértelmezési dilemmák az Alaptörvény hetedik módosításának európai integrációt érintő rendelkezéseivel kapcsolatban. In Közjogi Szemle, 2019/3. szám, pp. 48-53. 
Gros 2020: Daniel Gros: Voice or Exit? What other choice for Germany's Constitutional Court., 2020. május 18., https://www.ceps.eu/voice-or-exit/

Guerra 2013: Luis López Guerra: National Identity and the European Convention on Human Rights. In In Alejandro Saiz Arnaiz -, Carina Alcoberro Llivina (eds.): National constitutional identity and european integration. Intersentia, Cambridge - Antwerp Portland, 2013, pp. 305-322.

Habermas 1976: Jürgen Habermas: Zur Rekonstruktion des historischen Materialismus, Suhrkamp. K.n., Frankfurt am Main, 1976.

Habermas 1994: Jürgen Habermas: Képesek-e a komplex társadalmak ésszerü identitás kialakítására? In Felkai Gábor (szerk.): Jürgen Habermas - Válogatott tanulmányok (Ford.: Felkai Gábor). Atlantisz kiadó, Budapest, 1994

Halmai 2009: Halmai Gábor: Alkotmányos értékek és demokratikus konszolidáció. In Fundamentum, 2009/3. szám, pp. 31-48.

Halmai 2013: Halmai Gábor: Alkotmányjog - Emberi jogok - Globalizáció - Az alkotmányos eszmék migrációja, L’Harmattan Kiadó, Budapest, 2013

Hamul'ák - Sulyok - Kiss 2019: Ondrej, Hamul'ák - Márton, Sulyok - Lilla Nóra, Kiss: Measuring the 'EU'-Clidean Distance Between EU Law and the Hungarian Constitutional Court - Focusing on the Position of the EU Charter of Fundamental Rights. In Czech Yearbook of Public \& Private International Law, Volume 10, 2019, pp. 130-150,

Hanafin 2014: Patrick Hanafin: Resistant Lives: Law, Life, Singularity in Soft Power: Euro-American Journal of Historical and Theoretical Studies of Politics 1/2014, 91-109.

Hanák 1997: Hanák Péter: A nemzeti identitás konstrukciója és problémái. In Múlt és jövő, 1997/9. 
Hegel 1961: Georg Wilhelm Friedrich Hegel: A szellem fenomenológiája (ford: Szemere Samu). Akadémia kiadó, Budapest, 1961

Holmes 2012: Stephen Holmes: Constitutions and Constitutionalism. In Michel Rosenfeld - András Sajó: The Oxford Handbook of Comparative Constitutional Law, Oxford University Press, New York, 2012

Jacobsohn 2006: Gary Jeffrey Jacobsohn: Constitutional Identity, 364. p. In The Review of Politics, 2006/68. szám, pp. 361-397.

Jacobsohn 2010: Gary Jeffrey Jacobsohn: Constitutional Identity. Harvard University Press, Cambridge - London, 2010.

Jacobsohn 2013: Gary Jeffrey Jacobsohn: Az alkotmányos identitás változásai. In Fundamentum, 2013/1. szám, pp. 5-16.

Kaiser 2019: Kaiser Tamás: Kormányzási modellek a 21. században: a többszintü kormányzás fejlődése és típusai. In Kaiser Tamás (szerk.): A modern kormányzás koncepcionális és közpolitikai keretei - Hazai és nemzetközi dimenziók, Dialóg Campus Kiadó, Budapest, 2019, pp. 49-70.

Kellermann 2009: Gero Kellermann: ntegrationsverantwortung und Verfassungsidentität - Das Urteil des Bundesverfassungsgerichts zum Vertrag von Lissabon. In Akademie für politische bildung tutzing, Akademie-Kurzanalyse, 2009/1.

Körösényi 2004: Körösényi András: Demokráciadeficit, föderalizmus, szuverenitás. In Politikatudományi szemle, 2004/3. szám, 149-164.

Körtvélyesi 2013: Körtvélyesi Zsolt: Alkotmányosság a nemzeten túl: Az alkotmányos identitás egy természetrajza. In Fundamentum, 2013/1. szám

Kruzslicz 2014: Kruzslicz Péter: Előszó. In Jakó Mira Anna (szerk.): Nemzeti identitás és alkotmányos identitás az Európai Unió és a tagállamok viszonylatában, Nemzetközi és Regionális Tanulmányok 10., Generál, Szeged, 2014 
Kruzslicz 2019: Kruzslicz Péter Pál: A nemzeti alkotmányosság tagállami alapjai: a nemzeti szuverenitás és a nemzeti alkotmányos önazonosság, $\mathrm{PhD}$ értekezés, Szegedi Tudományegyetem, Állam- és Jogtudományi Doktori Iskola, Szeged, 2019

Lacan 1966: Jacques, Lacan: Écrits, Éditions du Seuil. K.n., Párizs, 1966

Láncos 2013: Láncos Petra Lea: Az Európai Unió értékeinek kikényszerítése és az értékek meghatározhatóságának problémája. In In Medias Res 2013/1. szám, 153-170.

Leino-Sandberg 2020: Päivi Leino-Sandberg: Who is Ultra Vires Now? The EU's Legal U-Turn in interpreting Article 310 TFEU. Verfassungsblog. 18 Jun 2020., https://verfassungsblog.de/who-is-ultra-vires-now-the-eus-legal-u-turn-in-interpretingarticle-310-tfeu/

Levade 2016: Anne Levade: Alkotmányos identitás a francia jogban -az európai jogrendszerekkel való párbeszéd eszköze. In SULYOK 2016, 68-72.

Majtényi 2017: Majtényi Balázs: Alkotmányos értékek játszmája az Európai Unióban: egytöl a huszonnyolcig. In MTA Law Working Papers, 2017/14.

Mankiw 2011: N. Gregory Mankiw: A közgazdaságtan alapjai, Osiris Kiadó, Budapest, 2011

Manurung 2015: Hendra Manurung: The European Identity Crisis on European Integration. In SSRN Electronic Journal. 10.2139/ssrn.2703867, 2015. Elérhető: https://www.researchgate.net/publication/314556180_The_European_Identity_Crisis_o n_European_Integration

Marinkás 2013: Marinkás György: Az emberi jogok védelmének fejlődése az Európai Unióban: az Unió csatlakozása az Emberi Jogok Európai Egyezményéhez, Miskolci Jogi Szemle 2013/1. szám 
Maris-Sklias 2016: Georgios Maris - Pantelis Sklias: symmetrical Sovereignty, European Integration, and the Grey Zone of European Union Politics. In Institutute of European Law Working Papers, 2016/4

Martinico 2013: Giuseppe Martinico: What Lies Behind Article 4(2) TEU? In In Alejandro Saiz Arnaiz -, Carina Alcoberro Llivina (eds.): National constitutional identity and european integration. Intersentia, Cambridge - Antwerp - Portland, 2013, pp. 93108.

Martonyi 2016: Martonyi János vitaindító előadása. In Sulyok Márton (szerk.): Párbeszéd és Identitás - Az alkotmányos identitás alapkérdései. Magyar Közlöny Lap- és Könyvkiadó Kft., Budapest, 2016, pp. 37-43.

Martonyi 2018: Martonyi János: Nyitás és identitás. Geopolitika, világkereskedelem, Európa, Pólay Elemér Alapítvány, Szeged, 2018

Möllers 2011: Alkotmányozó hatalom - Alkotmány - Alkotmányosság. (Ford.: Győri Gábor) In Fundamentum, 2011/2. szám

Mravik 2016: Mravik Balázs Áron: Úton a globális alkotmányosság felé. In Diskurzus A Széchenyi István Egyetem Deák Ferenc Állam- és Jogtudományi Kar Batthány Lajos Szakkollégiumának tudományos folyóirata, 2016/1. szám, pp.15-22.

Müller 2008: Jan-Werner Müller: Alkotmányos patriotizmus. In 2000 - Irodalmi és társadalmi havi lap, 2008/5. szám

Müller 2016: Peter Müller: Alkotmányos identitás és európai integráció a német Alaptörvény szemszögéböl. In: Sulyok Márton (szerk.): Párbeszéd és Identitás - Az alkotmányos identitás alapkérdései. Magyar Közlöny Lap- és Könyvkiadó Kft., Budapest, 2016

Orbán 2018: Orbán Endre: Quo vadis, „alkotmányos identitás”? In Közjogi Szemle, $2018 / 3$ 
Orbán 2020: Orbán Endre: Államszervezet és szubszidiaritás mint az alkotmányos identitás sarokpontjai az Európai Unióban, PhD értekezés, Budapest, 2020

Paczolay 2000: Paczolay Péter: A nemzeti, a vallási és az európai identitás. In Glózer Rita - Hamp Gábor - Horányi Özséb (szerk.): Vallások és az európai integráció II., Balassi Kiadó, Budapest, 2000

Pap 2014: Pap András László: Személyiségkép és alkotmányos identitás a nemzeti Együttműködés Rendszerében (I. rész). In Közjogi Szemle, 2014/4. szám

Pataki 1997a: Pataki Ferenc: Identitás - személyiség - társadalom. In Lengyel Zsuzsanna: Szociálpszichológia, Osiris Kiadó, Budapest, 1997

Pataki 1997b: Pataki Ferenc: A társadalmi „nagycsoportok” értékorientációi. In Lengyel Zsuzsanna: Szociálpszichológia, Osiris Kiadó, Budapest, 1997

Pérez 2013: Aida Torres Pérez: Constitutional Identity and Fundamental Rights: The Intersection between Articles 4(2) TEU and 53 Charter. In In Alejandro Saiz Arnaiz -, Carina Alcoberro Llivina (eds.): National constitutional identity and european integration. Intersentia, Cambridge - Antwerp - Portland, 2013, pp. 141-158.

Pernice 2006: Ingolf Pernice,: The Global Dimension of Multilevel Constitutionalism: A Legal Response to the Challenges of Globalisation. In Walter Hallstein-Institut Paper 9/08, 2006

Petrétei 2011: Petrétei József: Az Alkotmányos demokrácia alapintézményei. Dialóg Campus Kiadó, Budapest-Pécs, 2011

Podolnjak 2007: Robert Podolnjak: Explaining the Failure of the European Constitution: A Constitution-Making Perspective. In Collected Papers of Zagreb Law Faculty, Zagreb Law Faculty, Vol. 57, No. 1, 2007

Pokol 2018: Pokol Béla: Az uniós jurisztokrácia hatalmi szerkezete. In Jogelméleti Szemle, 2018/4. szám, pp. 126-191. 
Pokol 2019: Pokol Béla: Európai jurisztokrácia: Az Európai Unió jurisztokratikus szerkezetének kérdései, Dialog Campus Kiadó, Budapest, 2019

Polzin 2016: Monika Polzin: Constitutional identity, unconstitutional amendments and the idea of constituent power: The development of the doctrine of constitutional identity in German constitutional law. In ICON - International Journal of Constitutional Law Vol. 14. No 2 April 2016, pp., 411-438.

Polzin 2017: Monika Polzin: Constitutional Identity as a Constructed Reality and a Restless Soul. In German Law Journal 2017/7. szám

Prieger - Klemm 2019: Prieger Adrienn - Klemm Dávid: A Brexit eddigi folyamata. In Európai Jog, 2019/1. szám, pp. 12-22.

Pusztai 2014: Pusztai Ferenc (szerk.): Magyar Értelmező Kéziszótár. Akadémiai Kiadó, Budapest, 2014

Rixer 2011: Rixer Ádám: A történeti alkotmány lehetséges jelentéstartalmai. (12)3:2011 Jogelméleti Szemle

Rosenfeld 1995: Michel Rosenfeld: Identity of the Constitutional Subject, 1049. p. In Cardozo Law Review 1995/16. szám, pp. 1049-1111.

Rosenfeld 2010: Michel Rosenfeld: Identity of the Constitutional Subject: Selfhood, Citizenship, Culture and Community, Routledge. Taylor and Francis Group, London and New York, 2010.

Roznai 2017: Yaniv Roznai: Unconstitutional Constitutional Amendments The Limits of Amendment Power. Oxford Constitutional Theory, Oxford University Press, Oxford, 2017 
Rychetsky 2017: Pavel Rychetsky: Az alkotmányos identitás megtartása az Európai Unió keretén belül - az alkotmánybíróság feladata. In Alkotmánybírósági szemle, 2017/1. szám, pp. 95-98.

Sadurski 2006: Wojciech Sadurski: European Constitutional Identity? in EUI Working Paper, 2006/33

Sári-Somody 2008: Sári János - Somody Bernadette: Alapjogok - Alkotmánytan II. (Negyedik, átdolgozott kiadás), Osiris Kiadó, Budapest, 2008

Sigmund 2006: Anne-Marie Sigmund: Európai Gazdasági és Szociális Bizottság vélemény - Tárgy: „Hozzájárulás az Európai Tanács 2006. június 15-16-i üléséhez Gondolkodási időszak”. In Az Európai Unió Hivatalos Lapja, 49. évfolyam, 2006. augusztus 18., 2006/C 195/17. Elérhető: https://eur-lex.europa.eu/legalcontent/HU/TXT/?uri=OJ:C:2006:195:TOC

Smith 2016: Eivind Smith: A történeti hagyomány, mint az alkotmányos identitás eredője Skandináviában, különös tekintettel Norvégiára. In: Sulyok Márton (szerk.): Párbeszéd és Identitás - Az alkotmányos identitás alapkérdései, Magyar Közlöny Lap- és Könyvkiadó Kft., Budapest, 2016

Smuk 2013: Smuk Péter: Nemzeti értékek az Alaptörvényben. In Szoboszlai-Kiss Katalin - Deli Gergely (szerk.): Tanulmányok a 70 éves Bihari Mihály tiszteletére, Universitas-Győr Nonprofit Kft., Győr, 2013, 446-463.

Smuk 2014: Smuk Péter: Alkotmányjog I., Alkotmányos fogalmak és eljárások, Universitas-Győr Nonprofit Kft., Győr, 2014

Somssich 2018: Somssich Réka: Az alkotmányos identitás a francia és a belga alkotmánybírósági gyakorlatban. In Alkotmánybírósági Szemle, 2018/2. szám, pp. 9-19.

Stumpf 2018: Stumpf István: Alkotmányos párbeszéd. Gondolatok Drinóczi Tímea könyvét olvasván. In Alkotmánybírósági Szemle, 2018/2. szám, pp. 46-51. 
Stumpf 2020: Sovereignity, Constitutional Identity and European Law. In Hungarian Review, Volume XI, No. 3.

Sulyok 2014: Sulyok Márton: Nemzeti és alkotmányos identitás a nemzeti alkotmánybíróságok gyakorlatában. In: Jakó Mira Anna (szerk.): Nemzeti identitás és alkotmányos identitás az Európai Unió és a tagállamok viszonylatában, Nemzetközi és Regionális Tanulmányok 10. Generál, Szeged, 2014

Sulyok 2015: Sulyok Márton: Értelem és érzelem vagy büszkeség és balítélet? Alkotmánybíráskodás és alkotmányos identitás. In: Fontes Juris, 1/2015, 27-39.

Sulyok 2016a: Sulyok Márton: Előszó. In: Sulyok Márton (szerk.): Párbeszéd és Identitás - Az alkotmányos identitás alapkérdései. Magyar Közlöny Lap- és Könyvkiadó Kft., Budapest, 2016

Sulyok 2016b: Sulyok Márton: Kettő az egyben? Alkotmány és identitás. In Balogh Elemér (szerk.): Számadás az Alaptörvényről, Tanulmányok a Szegedi Tudományegyetem Állam- és Jogtudományi Kar oktatóinak tollából. Magyar Közlöny Lap- és Könyvkiadó Kft., Szeged, 2016, pp. 339-359.

Sulyok 2017a: Sulyok Márton: Magánszféravédelem a tisztességes eljárásban - Az alapjogsértő bizonyítás összehasonlító alkotmányjogi vizsgálata, PhD értekezés, Szeged, 2017

Sulyok 2017b: Sulyok Márton: Institutions of the European Union. In Anita Pelle Szilvia Váradi (eds.): Basics of EU Law, Publisher: Innovariant, Szeged, 2017, pp. 37 53.

Sulyok-Kiss 2019: Márton Sulyok - Lilla Nóra Kiss: In Unchartered Waters? The Place and Position of EU Law and the Charter of Fundamental Rights in the Jurisprudence of the Constitutional Court of Hungary. In Hungarian Yearbook of International Law and European Law Volume 7, 2019, pp. 395-417. 
Sulyok-Trócsányi 2009: Sulyok Márton - Trócsányi László: Preambulum. In Jakab András (szerk.): Az Alkotmány kommentárja (I. kötet). Századvég, Budapest, 2009, pp. 81-106.

Szabó 2019: Szabó Patrik: A felszín alatt. Adalékok az alkotmányos identitás elméleti és dogmatikai problémáihoz. In Közjogi Szemle, 2019/3. szám

Szajbély 2004: Szajbély Katalin: A vallási jelképek viseléséről szóló törvény Franciaországban. In: Jogelméleti Szemle, 2004/4. szám

Szakály 2015: Szakály Zsuzsa: Történeti alkotmány és az alkotmányos identitás az Alaptörvény tükrében. In Pro Publico Bono 2015/2. szám

Szakály 2018: Szakály Zsuzsa: Az alkotmány stabilitását védő garanciák. PhD dolgozat, Szegedi Tudományegyetem, Állam- és Jogtudományi Kar, Szeged, 2018

Szakály-Tribl 2018: Szakály Zsuzsa - Tribl Norbert: Örökkévaló identitás? Lehetséges kapcsolat az alkotmányos identitás és az örökkévalósági klauzulák között. In Pro Futuro, 2018/4. szám, pp. 9-25.

Szatmáry - Vinkó - Gergely - Keresztes 2013: Szatmáry Károly - Vinkó József Gergely Árpád László - Keresztes Zoltán: Asztrofizika, Interdiszciplináris és komplex megközelítésű digitális tananyagfejlesztés a természettudományi képzési terület mesterszakjaihoz, TÁMOP-4.1.2.A/1-11/1 MSc Tananyagfejlesztés, Szeged, 2013

Szmodis 2013: Szmodis Jenő: Az Alkotmány magja és annak védelme. In Jogelméleti szemle, 2013/2. szám, 156-167.

Szücs 2006: Szücs Anita: Az „exception francaise” erodálódása és a megváltozott francia nagyhatalmiság - PhD értekezés, Budapest, 2006

Takács 2007: Takács Imre: Az alkotmány és az alkotmányosság fogalma. In Kukorelli István (szerk.): Alkotmánytan I., Osiris Kiadó, Budapest, 2007 
Takács 2015: Takács Péter (szerk.): Az állam szuverenitása, Eszmény és/vagy valóság Interdiszciplináris megközelítések, Gondolat Kiadó, MTA TK JTI - SZE DFK, Budapest-Győr, 2015

Tarrósy 2006: Tarrósy István: A globális világrend és az Észak-Dél-kontextus. In Politikatudományi Szemle, 2006/2-3. szám

Tischendorf 2016: Michael Tischendorf: Theorie und Wirklichkeit der Integrationsverantworting deutscher Verfassungsorgane, Jus Internationale et Europaeum 129., Universitat Augsburg, 2016

Tribl 2018: Tribl Norbert: Az alkotmányos identitás fogalomrendszere jogelméleti megközelítésben. In Jogelméleti Szemle 2018/1. szám, 151-164.

Trócsányi 1989: Trócsányi László: Az alkotmánybíráskodás szervezete és müködése egyes európai országokban. MTA, Budapest, 1989

Trócsányi 2014a: Trócsányi László: Az alkotmányozás dilemmái. HVG Orac, Budapest, 2014

Trócsányi 2014b: Trócsányi László: Alkotmányos identitás és európai integráció. In Acta Universitatis Szegediensis: acta juridica et politica, 2014/76. kötet, pp. 473-476.

Trócsányi 2014c: Trócsányi László: Tagság, jogállamiság, Európai Unió. In Jakó Mira Anna (szerk.): Nemzeti identitás és alkotmányos identitás az Európai Unió és a tagállamok viszonylatában, Nemzetközi és Regionális Tanulmányok 10., Generál, Szeged, 2014, pp. 9-16.

Trócsányi 2014d: Trócsányi László: Nemzeti sajátosságok és európai konszenzus a nemzeti alkotmányok kapcsán. In Mire való egy alkotmány? - Nemzeti sajátosságok és európai konszenzus, Károlyi József Alapítvány - Helikon Kiadó, Budapest, 2014

Trócsányi 2014e: Trócsányi László: Tagság, jogállamiság, Európai Unió. In: Jakó Mira Anna (szerk.): Nemzeti identitás és alkotmányos identitás az Európai Unió és a 
tagállamok viszonylatában, Nemzetközi és Regionális Tanulmányok 10. Generál, Szeged, 2014

Trócsányi 2015: Trócsányi László: Nemzeti alkotmányok, európai integráció és alkotmányos identitás. In Tóth Judit (szerk.): Ünnepi kötet Dr. Tóth Tóth Károly címzetes egyetemi tanár 70. születésnapjára, Acta Universitatis Szegediensis, Acta Juridia Et Politica, Szeged, 2015

Trócsányi 2019: Trócsányi László: Új európai alkotmányjogi koncepciók. In Scholz Evelin (szerk.): Trócsányi László - Válogatott miniszteri beszédek 2014. június - 2019. június, pp. 51-58.

Trócsányi-Schanda 2016: Trócsányi László - Schanda Balázs: Bevezetés az alkotmányjogba - Az Alaptörvény és Magyarország Alkotmányos Intézményei (Ötödik, átdolgozott kiadás), HVG-Orac, Budapest, 2016

Tushnet 2003: Mark Tushnet: New Constitutional Order. Princeton University Press, 2003.

Tushnet 2008: Mark Tushnet: The Inevitable Globalization of Constitutional Law. In Public Law \& Legal Theory Working Paper Series Paper No. 09-06, 2008

Varga Zs. 2011: Varga Zs. András: A mag-alkotmány védelmében. Pázmány Law Working Papers, 2011/2

Varga Zs. 2015: Varga Zs. András: Eszményből bálvány? A joguralom dogmatikája, Századvég Kiadó, Budapest, 2015

Varga Zs. 2016a: Varga Zs. András: Történeti alkotmányunk vívmányai az Alaptörvény kógens rendelkezéseiben. Iustum Aequum Salutare XII. 2016. 4., pp. 83-89.

Varga Zs. 2016b: Varga Zs. András: Végleges szuverenitás vagy korlátozott hatáskörtranszfer? In Fontes Iuris: Az Igazságügyi Minisztérium szakmai folyóirata, 2016/1. szám, pp. 8-12. 
Várnay 2019: Várnay Ernő: Az Alkotmánybíróság és az Európai Bíróság. Együttmüködő alkotmánybíráskodás? In Állam- és Jogtudomány, 2019/2. szám, pp. 63-91.

Vincze 2009: Vincze Attila: Osztott szuverenitás - többszintü alkotmányosság. In Kocsis Miklós - Zeller Judit (szerk.): A köztársasági Alkotmány 20 éve, Tanulmánykötet: Pécsett 2009. szeptember 25-én megtartott "A köztársasági Alkotmány 20 éve" c. konferencián elhangzott előadások szerkesztett anyaga, Pécsi Alkotmányjogi Mühely Alapítvány, Pécs, 2009, pp. 363-376.

Vincze-Chronowski 2018: Vincze Attila - Chronowski Nóra: Magyar alkotmányosság az európai integrációban (Harmadik, átdolgozott, bővített kiadás), HVG Orac, 2018

Vincze-Chronowski 2018: Vincze Attila - Chronowski Nóra: Magyar alkotmányosság az európai integrációban (Harmadik, átdolgozott, bővített kiadás), HVG Orac, Budapest, 2018

Weiler 1991: J. H. H. Weiler: The Transformation of Europe. In Yale Law Journal, Volume 100, Issue 8, pp. 2405-2483.

Zeller 2005: Zeller Judit (szerk.): Alkotmányjogi esetek, Dialóg Campus Kiadó, Pécs, 2005

Zétényi 2009: Zétényi Zsolt: A történeti alkotmány. Magyarország ősi alkotmánya, Magyarországért Kulturális Egyesület, Budapest, 2009

Zsugyó 2019: Zsugyó Virág: „Örökkévalósági klauzula” működésben - A Német Alkotmánybíróság gyakorlata. In Közjogi Szemle 2019/1. szám, pp. 69-73. 


\subsection{Az EUB és a tagállami alkotmánybíróságok hivatkozott határozatai}

C-6/64 - Flaminio Costa kontra E.N.E.L. üg

Simmenthal (I) ügy (35/76 Simmenthal SpA v Ministere des finances italien, 1976)

26/62. sz. Van Gend en Loos ügy

C-105/14. Taricco és társai ügy

C-58/13. Angelo Alberto Torresi ügy

C-59/13. Pierfrancesco Torresi vs. Consiglio dell'Ordine degli Avvocati di Macerata ügy

C-208/09 Ilonka Sayn-Wittgenstein vs. Landeshauptmann von Wien ügy

C-399/11 Melloni ügy

C-213/07 Michaniki ügy

C-493/17 ügy Weiss ügy

C-294/83 Les Verts ügy

C-357/19 sz. ügy (Az értekezés kéziratának lezárásakor: Az Înalta Curte de Casație și Justiție (Románia) által 2019. május 6-án benyújtott előzetes döntéshozatal iránti kérelem

- Parchetul de pe lângă Înalta Curte de Casaţie și Justiţie - Direcția Naţională Anticorupție, PM, RO, SP, TQ kontra QN, UR, VS, WT, Autoritatea Naţională pentru Turism, Agenția Națională de Administrare Fiscală, SC Euro Box Promotion SRL)

33/2012 (VII. 17.) Alkotmánybírósági Határozat

22/2016. (XII. 5.) Alkotmánybírósági Határozat

45/2012 (XII.29.) Alkotmánybírósági Határozat

143/2010 (VII.14.) Alkotmánybírósági Határozat

6/2013. (III. 1.) Alkotmánybírósági Határozat

2/2019. (III.5.) Alkotmánybírósági Határozat

Cseh Alkotmánybíróság PL. ÚS 19/08 sz. döntése

Cseh Alkotmánybíróság Pl. ÚS 5/12 sz. döntése

Horvát Alkotmánybíróság U-IP-3820/2009 sz. döntése

Horvát Alkotmánybíróság U-IP-3826/2009 sz. döntése

Horvát Alkotmánybíróság U-I-3597/2010 sz. döntése

Horvát Alkotmánybíróság U-VIIR-5292/2013 sz. döntése

Horvát Alkotmánybíróság U-VIIR-1159/2015 sz. döntése

Horvát Alkotmánybíróság U-II-6111/2013 sz. döntése

Horvát Alkotmánybíróság U-VIIR-164/2014 sz. döntése 
Lett Alkotmánybíróság 2015-01-01-i döntése

Lett Alkotmánybíróság 2017-01-01-i döntése

Német Szövetségi Alkotmánybíróság 2 BvR 859/15 sz. döntése

Német Szövetségi Alkotmánybíróság 2 BvR 2728/13 sz. döntése

Szlovák Alkotmánybíróság Pl. ÚS 24/2014 sz. döntése

Szlovák Alkotmánybíróság PL. ÚS /2017 sz. döntése

Szlovák Alkotmánybíróság II. ÚS 171/2005 sz. döntése

Szlovák Alkotmánybíróság III. ÚS 427/2012 sz. döntése

Szlovák Alkotmánybíróság PL ÚS 7/2017 sz. döntése

\subsection{Hivatkozott tagállami alkotmányok és nemzetközi szerződések}

Az Európai Unióról Szóló Szerződés

Az Európai Alkotmányt létrehozó szerződés tervezete (nem ratifikált szerződés)

Magyarország Alaptörvénye

A Német Szövetségi Köztársaság Alaptörvénye

Lettország Alkotmánya (Satversme) 


\subsection{Internetes hivatkozások}

(Az internetes hivatkozások esetén az elérhetőség ellenőrzésének dátuma egységesen 2020. 08. 16.)

Trócsányi László: A közös európai alkotmányos örökség — Polner Ödönre emlékezve http://www.juris.u-szeged.hu/download.php?docID=45152

Schuman-nyilatkozat

http://europa.eu/about-eu/basic-information/symbols/europe-day/schumandeclaration/index_hu.htm

Managing Migration in all its Aspect: Progress under the European Agenda on Migration $\operatorname{COM}(2018) 798$

https://ec.europa.eu/home-affairs/sites/homeaffairs/files/what-we-do/policies/europeanagenda-migration/20181204_com-2018-798-communication_en.pdf

Hüposztatikus egység - Magyar Katolikus Lexikon http://lexikon.katolikus.hu/H/hüposztatikus\%20egység.html

Az Európai Alkotmányszerződés egységes szerkezetbe foglalt szövege http://europa.eu/eu-law/decision making/treaties/pdf/treaty_establishing_a_constitution_for_europe/treaty_establishing a_constitution_for_europe_hu.pdf

Az EUSZ 4. cikkében foglalt rendelkezések tervezetének javaslata (CONV 375/1/02 REV 1)

http://european-convention.europa.eu/pdf/reg/en/02/cv00/cv00375-re01.en02.pdf http://european-convention.europa.eu/pdf/reg/en/02/cv00/cv00251.en02.pdf

Tommasso Pavone: Constitutional Identity: An Overview and Some Conceptual Concerns

https://scholar.princeton.edu/sites/default/files/tpavone/files/jacobsohn_constitutional_identity_critical_review.pdf 
Bakk Miklós: A nemzeti identitás, mint politikai identitás

http://bakk.adatbank.transindex.ro/belso.php?k=2\&p=4170

http://www.oxforddictionaries.com/definition/english/self

Commission President reacts to German Federal Constitutional Court's ruling on ECB's PSPP programme:

https://eulawlive.com/commission-president-reacts-to-german-federal-constitutionalcourts-ruling-on-ecbs-pspp-programme/

https://www.parlament.hu/biz39/eib/link1/eualkotmany.htm

https://www.ecb.europa.eu/mopo/implement/omt/html/pspp.en.html

A Lett Alkotmányügyi Bizottság által a lett alkotmányos identitásról készült részletes vizsgálat lett nyelven:

http://blogi.lu.lv/tzpi/files/2017/03/17092012_Viedoklis_2.pdf

Ineta Ziemele: Role of the Constitutional Courts in Upholding and Applying the Constitutional Principles: the Case of Latvia

http://www.satv.tiesa.gov.lv/en/articles/role-of-the-constitutional-courts-in-upholdingand-applying-the-constitutional-principles-the-case-of-latvia/

A Next Generation EU és európai helyreállítási terv összefoglalója:

https://ec.europa.eu/info/live-work-travel-eu/health/coronavirus-response/recoveryplan-europe hu

Kelemen R. Daniel, Piet Eeckhout, Federico Fabbrini, Laurent Pech és Uitz Renáta közös nyilatkozata a Verfassungsblogon 2020. május 26-án:

https://verfassungsblog.de/national-courts-cannot-override-cjeu-judgments/ 


\section{Mellékletek}

\section{1. sz. melléklet - Kérdőív az alkotmányos identitásról, az örökkévalósági klauzulákról és kapcsolatáról az EU tagállamok AB-gyakorlataiban (2018)}

"As researchers at the University of Szeged, Hungary (Faculty of Law and Political Sciences, Constitutional Law Department), our field of interest is the examination of eternity clauses and constitutional identity in the Member States of the European Union. We explore the applicability of eternity clauses and references to constitutional identity in the jurisprudence of the national high courts or constitutional courts (or institutions with the same purpose, hereinafter: institution).

In helping our intentions, we would appreciate if you could facilitate our research by completing the following short questionnaire about the jurisprudence of your institution on the above-mentioned issues.

\section{Synopsis of the Questionnaire}

Our approach underlying the questionnaire is based on the following premises:

(1) Addressing "constitutional identity", our research has revealed that the very notion remained far undefined across the integration. Consequently, our aim is to map out what the Member States understand under this concept. We approach "constitutional identity" as the "self-definition" of the constitutional systems of the respective Member States; as the ensemble of fundamental constitutional provisions and institutions with historical origins that define the constitutional system. We consider these to be untouchable by EU law.

(2) As the inherent attribute of the constitutional system, constitutional identity embodies "constitutional uniqueness", which is reflected through the national constitutions and acts of constitutional magnitude (e.g. organic laws in France).

(3) In our point of view the concept of national identity under Article 4 (2) TEU shall be matched up with the notion of constitutional identity. Throughout our research, we apply the definition of national identity as "the Lisbon-concept" of constitutional identity under Article 4 (2) TEU.

(4) For the purposes of our research we define "eternity clauses" as those provisions of the national constitutions, which cannot be amended, and the amendment of which can only take place through the adoption of a new constitution.

\section{Statement of Purpose}

The filled-out questionnaires will be analyzed and presented at international conferences. In addition, we shall organize our findings into publications for dissemination in national and international scientific journals.

Our long-term objective is to organize a conference with the cooperation of the representatives of those courts that will have provided us with answers, to debate the 
similarities and the differences between the practices of the Member States. Furthermore, all the contributing institutions will also be directly notified about the results of the research to keep them engaged in the dialogue about this topic.

\section{Contacts}

Please send us the completed questionnaire until the 1st of April 2018.

If the relevant decisions or judgments (or their summaries) are available in English, please, share the available source of the English with us to help our in-depth analysis.

We shall express our thanks and appreciation for your cooperation in advance. Should you have any questions regarding our survey, we kindly ask you to do not hesitate to contact us.

Szeged-Budapest, 12 January 2018

Yours sincerely,

Zsuzsa Szakály, dr. jur.

Assistant Professor

szakaly.zsuzsa@juris.u-szeged.hu
Norbert Tribl, dr. jur.

$\mathrm{PhD}$ student

tribl@juris.u-szeged.hu

Constitutional Law Department

Faculty of Law and Political Sciences

University of Szeged

\section{Questionnaire}

\section{Constitutional Identity}

1. Based on the national constitution, can national and/or constitutional identity be recognized in your country?

If yes, please indicate the relevant section(s) of the constitution.

2. Has your institution already referred to national and/or constitutional identity in its earlier decisions, particularly in the past 10 years?

If it has, please present the decisions in which the reference has been made and summarize how is the very concept defined in your jurisprudence?

3. Is there any reference to constitutional identity in national legal literature or in the practice of other institutions? (If there are any, please, specify some of the most relevant English-language sources.) 


\section{Eternity Clauses}

1. Is there an eternity clause in your national constitution, or is there another provision, which can be interpreted as an "implied" (extrinsic) eternity clause advocated by your institution?

a. If yes, please present the relevant section(s) of the constitution.

b. If no, please indicate if any part of the constitution or any principle of customary law shall be interpreted to have the same purpose as an eternity clause:

(Please disregard the following Question 2 in case your answer has been la above.)

2. Has your institution already referred to the eternity clause(s) in your constitution, particularly in the jurisprudence of the past 10 years?

If yes, please introduce the decisions in which the reference has been made:

3. Is there any mention of eternity clauses in your national legal literature or in the practice of other national institutions? (Please, offer some of the most relevant English-language sources of your national literature, if any.)

\section{Possible connections between constitutional identity and eternity clauses}

1. If your institution applies references to national or constitutional identity and if the national constitution does contain an eternity clause, is there any relationship between the two concepts in the jurisprudence of your institution?

a. If yes, how is such link interpreted in your practice?

b. Please indicate the relevant decision(s) within your jurisprudence (if any):

\section{Connections between national and EU law within the national constitution - respecting the margins of constitutional identity}

1. Is there a clause in your constitution that regulates the relationship between the national legal system and the law of the European Union?

b. If yes, has an interpretation / decision been made - based on this national constitutional provision - regarding the relation between the law of the European Union and the national constitution?

b. Please show us the relevant decision(s), and identify the possible conflicts between the two legal systems:" 
2. sz. melléklet - A tagállami alkotmánybíróságok által a kérdőívre megküldött válaszok összesítése

\begin{tabular}{|c|c|c|}
\hline $\begin{array}{l}\text { Örökkévalósági klau } \\
\text { uniós tagállamok alk }\end{array}$ & $\begin{array}{l}\text { Ilák és alkotmányos identit } \\
\text { tmányában, illetve alkotmá }\end{array}$ & $\begin{array}{l}\text { a kérdőívet visszaküldő } \\
\text { ybírósági gyakorlatában }\end{array}$ \\
\hline Visszaküldő tagállam & Örökkévalósági klauzula & Alkotmányos identitás \\
\hline Ausztria & $\begin{array}{l}\text { Nincs explicit örökkévalósági } \\
\text { klauzula. } \\
\text { Implicit “kvázi” örökkévalósági } \\
\text { klauzula (jogtudományi álláspont } \\
\text { alapján): } \\
\text { - Demokratikus } \\
\text { hatalomgyakorlás, } \\
\text { - Jogállamiság }\end{array}$ & $\begin{array}{l}\text { Az Alkotmánytörvény 1. és } 2 . \\
\text { cikke alapján: } \\
\text { - } \\
\text { Demokratikus } \\
\text { joggyakorlás } \\
\text { követelménye } \\
\text { - Jogállamiság } \\
\text { - } \quad \text { Köztársasági } \\
\text { államforma } \\
\text { - Föderatív } \\
\text { berendezkedés } \\
\text { - Az Alkotmánytörvény } \\
\text { 44. cikk (3) bekezdése: } \\
\text { az alkotmánytörvény } \\
\text { teljes revíziójához } \\
\text { népszavazás szükséges. } \\
\text { - AB: Az } \\
\text { Alkotmánytörvény 1. és } \\
\text { 2. cikkének módosítása } \\
\text { esetén a a } \\
\text { alkotmánytörvény teljes } \\
\text { revíziójára van szükség. }\end{array}$ \\
\hline Csehország & $\begin{array}{l}\text { Explicit örökkévalósági klauzula } \\
\text { (Alkotmány 9. cikk) } \\
\text { A jogállamiság által } \\
\text { meghatározott alkotmányos } \\
\text { berendezkedés. } \\
\text { Alkotmánybírósági gyakorlat: } \\
\text { - No. PL. ÚS 19/08 sz. } \\
\text { döntés: nemzetközi } \\
\text { szervezetre ('igy az EU) } \\
\text { történő } \\
\text { hatáskörátruházás nem } \\
\text { sértheti a köztársaság } \\
\text { "lényegét." } \\
\text { - No. PL. ÚS 27/9 sz. } \\
\text { döntés }\end{array}$ & $\begin{array}{l}\text { No. Pl. ÚS 5/12 sz. döntés } \\
\text { (“Slovak Pensions Case”): } \\
\text { A Cseh Köztársaság } \\
\text { alkotmányos identitása a } \\
\text { Szlovák Köztársasággal közös } \\
\text { múlt által meghatározott. }\end{array}$ \\
\hline
\end{tabular}




\begin{tabular}{|c|c|c|}
\hline Horvátország & 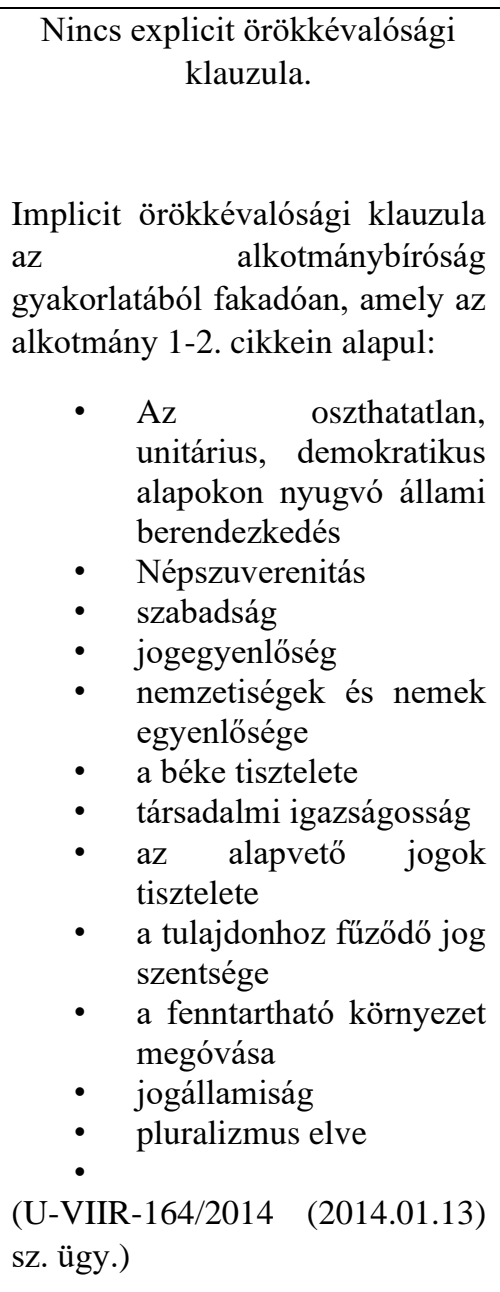 & $\begin{array}{l}\text { Az alkotmánybíróság vonatkozó } \\
\text { döntései: } \\
\text { U-IP-3820/2009 sz. döntés } \\
\text { U-IP-3826/2009 sz. döntés } \\
\text { U-I-3597/2010 sz. döntés } \\
\text { U-VIIR-5292/2013 sz. döntés } \\
\text { U-VIIR-1159/2015 sz. döntés } \\
\text { U-II-6111/2013 sz. döntés } \\
\\
\text { - Alapvetö értékek } \\
\text { Alapvető elvek } \\
\text { A horvát állam } \\
\text { strukturális felépítése } \\
\text { - Szociális állam } \\
\text { Nemzeti kisebbségek } \\
\text { védelme } \\
\text { Demokratikus } \\
\text { hatalomgyakorlás }\end{array}$ \\
\hline Lettország & $\begin{array}{l}\text { Nincs explicit örökkévalósági } \\
\text { klauzula. } \\
\text { Implicit örökkévalósági klauzula: } \\
\text { "A Satversme625 magja”: 1-4. } \\
\text { cikk, 6. cikk, 77. cikk } \\
\text { - Független, demokratikus } \\
\text { köztársaság } \\
\text { - Aépszuverenitás } \\
\text { - Az államterület } \\
\text { - A lett nyelv } \\
\text { - A parlametianti válaszló } \\
\text { alapvető szabályai. } \\
\text { Alkalmazás: conditio sine qua non } \\
\text { tesztje. }\end{array}$ & $\begin{array}{l}\text { Az alkotmánybíróság 2015-01- } \\
\text { 01-i döntésének 15.2. pontja, } \\
\text { illetve } \\
\text { 2017-01-01-i döntésének } 16 . \\
\text { pontja alapján: } \\
\text { - Szuverenitás } \\
\text { - Nemzeti függetlenség } \\
\text { - Területi integritás } \\
\text { - Demokratikus } \\
\text { hatalomgyakorlás } \\
\text { - Lett nyelv tisztelete } \\
\text { Alapvető emberi és } \\
\text { keresztény értékek } \\
\text { A lett nemzeti zászló és } \\
\text { a nemzeti jelképek } \\
\text { tisztelete }\end{array}$ \\
\hline
\end{tabular}

${ }^{625}$ Lettország alkotmánya. 


\begin{tabular}{|c|c|c|}
\hline Málta & 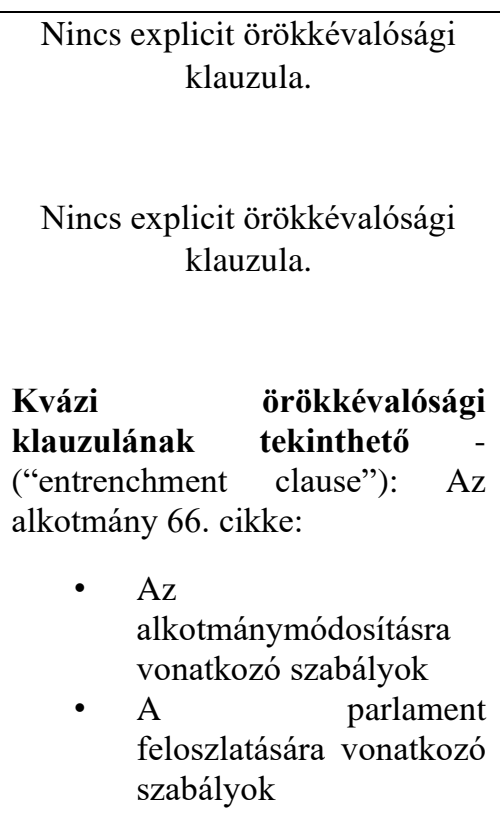 & 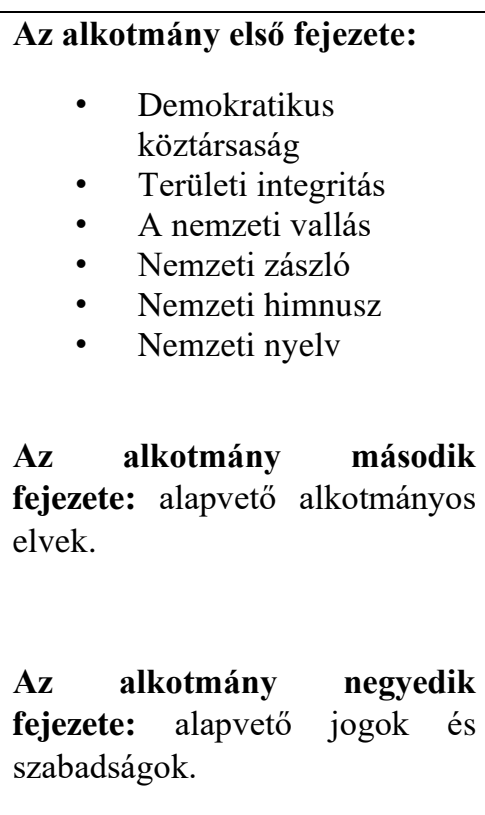 \\
\hline Németország & 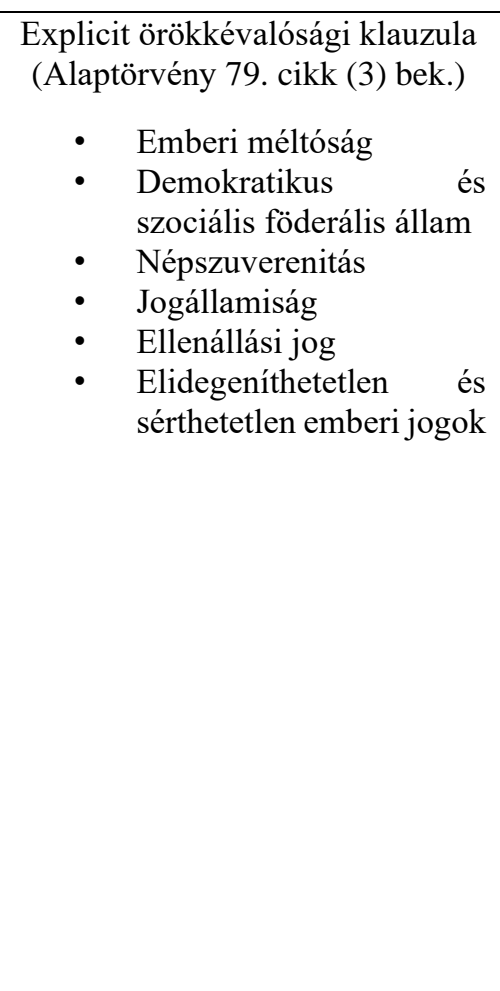 & $\begin{array}{l}\text { Az alkotmánybíróság kiterjedt } \\
\text { gyakorlattal rendelkezik. } \\
\text { Alaphatározatnak a "Lisszabon- } \\
\text { döntés" (Entscheidungen des } \\
\text { Bundesverfassungsgerichts- } \\
\text { BVerfGE) tekinthető (123, 267, } \\
\text { 268. pontok). A gyakorlat, illetve } \\
\text { az alaptörvény 79. cikk (3) } \\
\text { bekezdés alapján: } \\
\text { - Az emberi méltóság } \\
\text { védelme demokratikus } \\
\text { A hatalomgyakorlás } \\
\text { - A jogállamiság } \\
\text { - A szociális állam } \\
\text { Föderális } \\
\text { berendezkedés } \\
\text { A német alkotmányos identitás } \\
\text { forrása az alkotmánybíróság } \\
\text { következetes gyakorlata alapján } \\
\text { az örökkévalósági klauzula. }\end{array}$ \\
\hline Szlovákia & $\begin{array}{l}\text { Nincs explicit örökkévalósági } \\
\text { klauzula. } \\
\text { Implicit örökkévalósági klauzula: } \\
\text { Az alkotmány 1.1., 12.1. és } 93.3 \text {. } \\
\text { pontjában foglalt rendelkezések, } \\
\text { amely alapján: } \\
\text { • Szuverenitás }\end{array}$ & $\begin{array}{l}\text { Az alkotmánybíróság vonatkozó } \\
\text { döntései: } \\
\text { II. ÚS } 171 / 2005 \text { sz. döntés } \\
\text { III. ÚS } 427 / 2012 \text { sz. döntés } \\
\text { PL ÚS 7/2017 sz. döntés }\end{array}$ \\
\hline
\end{tabular}




\begin{tabular}{|c|c|c|}
\hline & $\begin{array}{l}\text { - Demokratikus } \\
\text { hatalomgyakorlás } \\
\text { - Jogállamiság } \\
\text { Alapvetö jogok és } \\
\text { szabadságok védelme } \\
\text { Az állami költségvetés } \\
\text { alapvető jogok } \\
\text { érvényesülését érintő } \\
\text { részei. }\end{array}$ & $\begin{array}{l}\text { Amely alapján az alkotmányos } \\
\text { identitás elemei: } \\
\text { - Az államiságot és } \\
\text { szuverenitást kifejező és } \\
\text { megtestesítő elnöki } \\
\text { hivatal } \\
\text { - Köztársasági } \\
\text { államforma } \\
\text { - Demokratikus } \\
\text { - hatalomgyakorlás } \\
\text { - Jogállamiság } \\
\text { Alapvetö jogok és } \\
\text { szabadságok védelme }\end{array}$ \\
\hline Szlovénia & $\begin{array}{l}\text { Nincs explicit örökkévalósági } \\
\text { klauzula. } \\
\text { Nincs implicit örökkévalósági } \\
\text { klauzula. }\end{array}$ & $\begin{array}{l}\text { Az alkotmánybíróság } \\
\text { joggyakorlatában nem található } \\
\text { az alkotmányos identitásra } \\
\text { vonatkozó hivatkozás vagy } \\
\text { utalás. }\end{array}$ \\
\hline
\end{tabular}




\section{3. sz. melléklet - A Lett Alkotmányügyi Bizottság alkotmányos identitásra vonatkozó jelentésének kivonata angol nyelven}

In 2012 the Constitutional Law Commission - a group of eminent experts convened by the President of the State - published a report "On the Constitutional Foundation of the State of Latvia and on the Inviolable Core of the Satversme [the Constitution of the Republic of Latvia]" (hereinafter - the Commission Report). ${ }^{626}$

Some of the more relevant excerpts from the Commission Report are as follows:

1) The constitutional identity of a state is formed by two components: the identity of the state ... and the identity of the institutional set-up of the state. If the identity of the state is changed, this is very likely to lead to a demise of the state within the meaning of international law and then there is no longer any reason to discuss the identity of the institutional set-up of the state. ${ }^{627}$

2) The most significant functional difference between the international law identity of the state and the state law identity of the state is that the international law identity of the state merely determines whether a specific form of organisation of society is a state but the state law identity of the state determines what kind of a state it is. ${ }^{628}$

3) Constitutions contain "coded" (direct or indirect) references to the history, traditions, language of a state (a nation), circumstances of the creation of a state, the aims of a state or other elements that from the perspective of constitutional law allow to constitute and identify the particular state, to provide it with a specific meaning, to characterise it, to determine what distinguishes it from other states that exist at the same time or from other previously extant "predecessor states" or occasionally also from competing states. These elements characterise the constitutional identity of the given state from the perspective of state law. ${ }^{629}$

4) There are criteria according to which it is possible to determine that the currently existing state that is entitled "the Republic of Latvia" is the state of

\footnotetext{
${ }^{626}$ Par Latvijas valsts konstitucionālajiem pamatiem un neaizskaramo Satversmes kodolu. Konstitucionālo tiesību komisijas viedoklis un materiāli, 2012.

627 The Commission Report. p. 51.

628 The Commission Report. p. 56.

${ }^{629}$ The Commission Report. p. 57.
} 
Latvia envisaged by the Satversme [the Constitution] and that the structure of this state is indeed a democratic structure. These criteria then determine the state law identity of Latvia and the identity of the institutional set-up of Latvia. Latvia has its own specific constitutional identity that encompasses, first of all, the state law identity of Latvia (that determines that this is exactly the state of Latvia rather than some other state or its component) and, second, the identity of the institutional set-up of Latvia (that determines that the structure of the state of Latvia is indeed democratic, rather than, for instance, authoritarian). ${ }^{630}$

5) The core of the Satversme contains the constitutional identity of the state of Latvia and postulates its protection (inviolability). The core of the Satversme in such a context should be defined as a principle of constitutional law (and hence as an unwritten legal norm) that supplements the written text of the Satversme in such a way as to not allow the constitutional legislator to amend the constitutional identity of the state of Latvia. ${ }^{631}$

6) Latvia is a national state of the Latvian nation. This element of the identity of the state has existed ever since the establishment of the state of Latvia and after the restoration of the independence it is in even more categorical form (albeit still in a fragmented manner) reflected in the text of the Satversme. Complying with this identity is the obligation of the state authorities. ${ }^{632}$

7) Latvia is the state of Latvia defined by the Satversme only in case if it consists of the ethnographically and historically ascertainable Latvian lands that are mentioned in Article 3 of the Satversme. This is one of the elements of the state identity of Latvia that is contained in the core of the Satversme. ${ }^{633}$

8) The people of Latvia cannot exist without its main element - the Latvian nation. In such a case it would not be the same state of Latvia that was established on 18 November 1918 and continues to exist but it would be a different state with another identity. ${ }^{634}$

${ }^{630}$ The Commission Report. p. 78

${ }^{631}$ The Commission Report. pp. 78-79.

${ }^{632}$ The Commission Report. p. 97.

${ }^{633}$ The Commission Report. p. 98.

${ }^{634}$ The Commission Report. pp. 101-102. 
9) The structure of the state of Latvia is defined in Article 1 of the Satversme. It is described as a democratic republic. This concept is a summary of the identity of the institutional set-up of Latvia. ${ }^{635}$

10) If a language that is not the Latvian language were chosen as the official language of Latvia, this would be contrary to the object and purpose for which the state of Latvia was established; this object and purpose bestows upon the state of Latvia a particular - and exactly Latvian - national cultural identity. ${ }^{636}$

11) Article 3 of the Satversme does not preclude setting borders of Latvia by means of international treaties; neither does it preclude insignificant changes to the territory. The decisive criterion is whether these changes are so significant as to consider that one or more of the regions mentioned in Article 3 of the Satversme is no longer the territory of Latvia. In such a case one may consider that the identity of the state has changed. ${ }^{637}$

${ }^{635}$ The Commission Report. p. 103.

${ }^{636}$ The Commission Report. p. 109.

${ }^{637}$ The Commission Report. pp. 98-99. 